Columbia Law School

Scholarship Archive

2013

\title{
Managed Coastal Retreat: A Legal Handbook on Shifting Development Away from Vulnerable Areas
}

Anne Siders

Columbia Law School, Sabin Center for Climate Change Law

Follow this and additional works at: https://scholarship.law.columbia.edu/sabin_climate_change

Part of the Environmental Law Commons

\section{Recommended Citation}

Anne Siders, Managed Coastal Retreat: A Legal Handbook on Shifting Development Away from Vulnerable Areas, Sabin Center for Climate Change Law, Columbia Law School, October 2013 (2013).

Available at: https://scholarship.law.columbia.edu/sabin_climate_change/147

This Report is brought to you for free and open access by the Research Centers \& Programs at Scholarship Archive. It has been accepted for inclusion in Sabin Center for Climate Change Law by an authorized administrator of Scholarship Archive. For more information, please contact scholarshiparchive@law.columbia.edu, rwitt@law.columbia.edu. 


\section{d. Columbia LaW School}

CENTER FOR CLIMATE CHANGE LAW

\section{MANAGED CoAstal Retreat}

\section{A LEgal HaNDBook ON SHIFTING DEVELOPMENT AWAY FROM VULNERABLE AREAS}

BY ANNE SIDERS

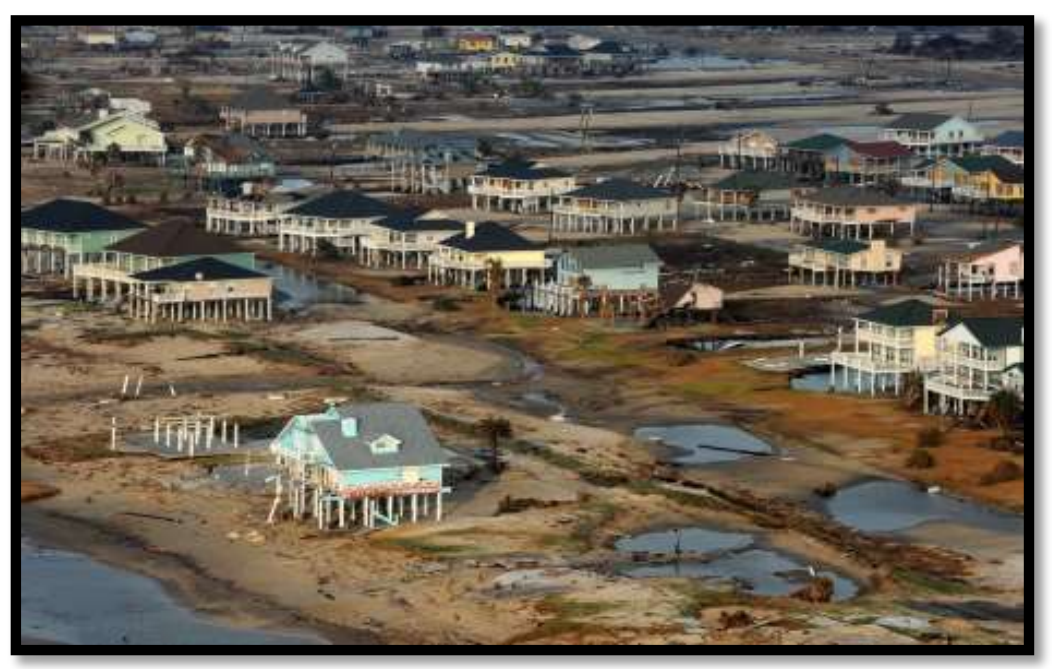

OCtOBER 2013 
This page intentionally blank 
(C) 2013 Columbia Center for Climate Change Law, Columbia Law School

Cover image: Hurricane Ike Damage in Texas, from the Federal Emergency Management Agency, http://www.fema.gov/region-vi/new-modern-national-flood-insurance-program-nfip.

The Columbia Center for Climate Change Law (CCCL) develops legal techniques to fight climate change, trains law students and lawyers in their use, and provides the legal profession and the public with up-to-date resources on key topics in climate law and regulation. It works closely with the scientists at Columbia University's Earth Institute and with a wide range of governmental, nongovernmental and academic organizations.

Managed Coastal Retreat: A Handbook of Tools, Case Studies, and Lessons Learned

October 2013

Columbia Center for Climate Change Law Columbia Law School

435 West 116th Street

New York, NY 10027

Tel: +1 (212) 854-2372

Web: http://www.ColumbiaClimateLaw.com

Twitter: @ColumbiaClimate

This report was written by Anne Siders, Associate Director of CCCL and edited by Professor Michael B. Gerrard, CCCL Director. Background research was contributed by Columbia Law School students Ifeoma Anunkor, Eugene Baek, James Crowley, and Ololade Oladopo; Columbia Law School students and Environmental Law Clinic participants Jean Choi, Robert Denicola, Andrew Kirchner, and Xiaotang Wang; Columbia University student Nicole Migliore; and Ann Tran and Smita Walavalkar. We would like to thank Peter Byrne, Jessica Grannis, Eleanor Saunders, and Courtney St. John for their comments and suggestions.

The text is the responsibility of CCCL alone, and does not reflect the views of Columbia Law School or Columbia University. 
"As the coasts become increasingly populated, more and more people are placed in harm's way. Thus far, science has not found effective ways to reduce most hazards. Therefore, citizens must look to strengthening communities. Building safer buildings and strengthening infrastructure are important steps, but it is the manner in which societies are built that largely determines disaster resilience. A vital part of effective disaster planning-whether for mitigation, preparation, response, or recovery-is an understanding of the people and institutions that make up each community, including their strengths and their weaknesses, as a basis for developing policies, programs, and practices to protect them. In the end, it is human decisions related to such matters as land use planning and community priorities that will build stronger, safer, and better communities."

- H. John Heinz III Center for Science, Economics and the Environment, 2002, Human Links to Coastal Disasters 


\section{TABLE OF CONTENTS}

Acronyms and Abbreviations

Coastal Geography and Terms

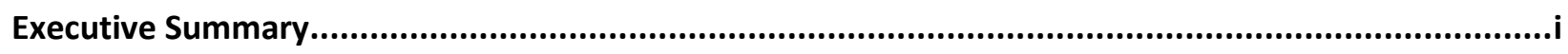

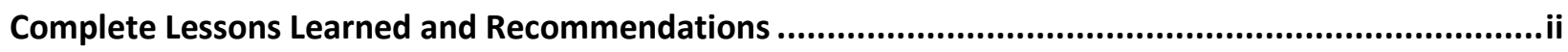

Introduction

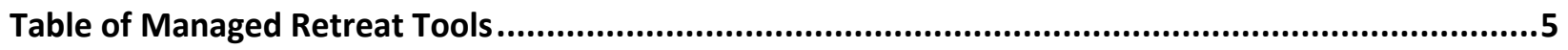

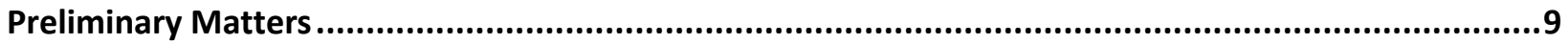

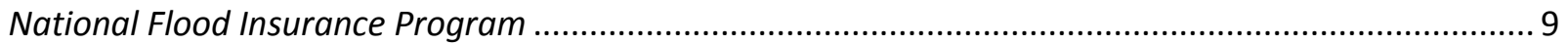

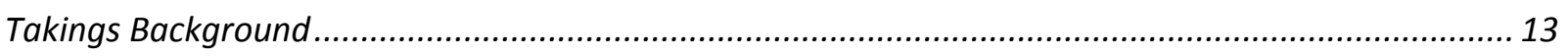

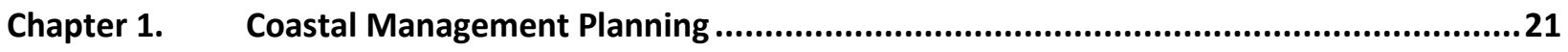

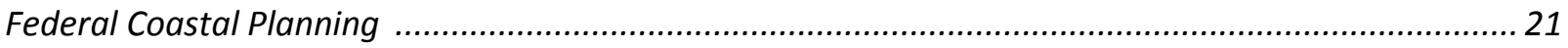

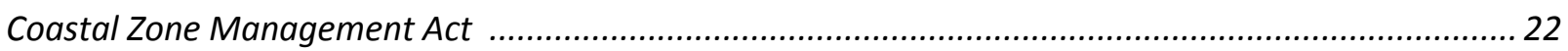

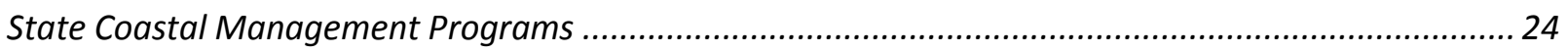

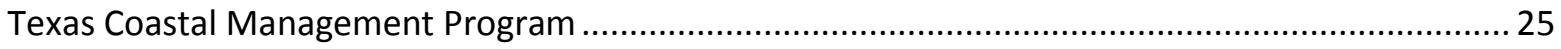

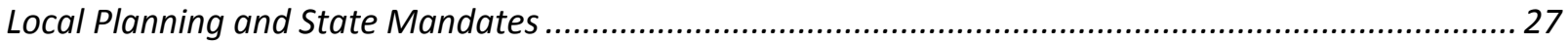

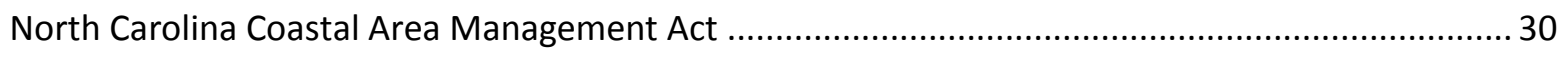

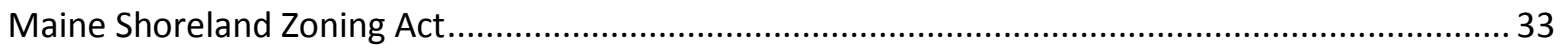

Chapter 2. Setbacks and Rolling Easements ......................................................................41

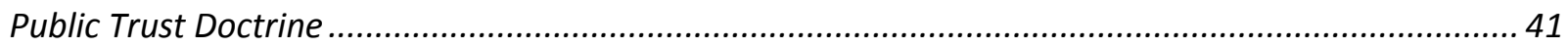

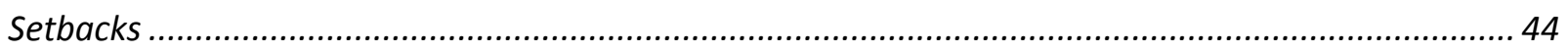

Florida Coastal Construction Control Line …............................................................................. 47

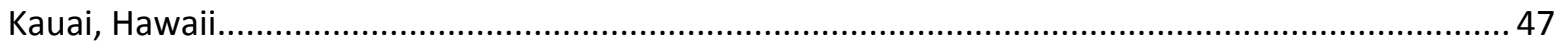

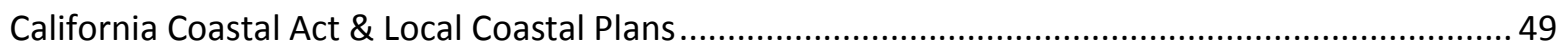

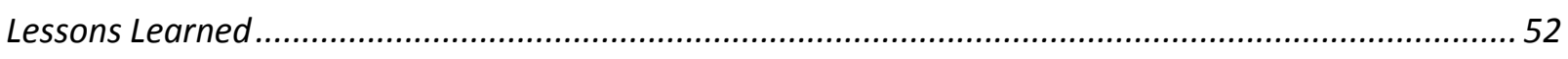

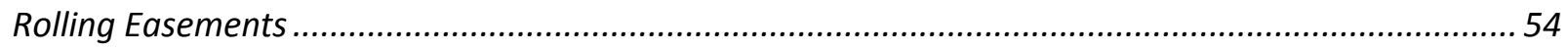

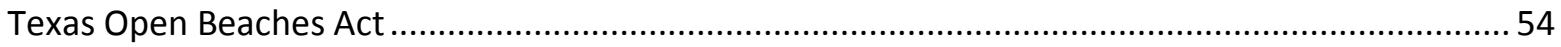

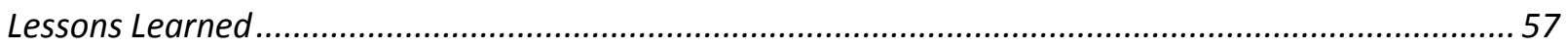

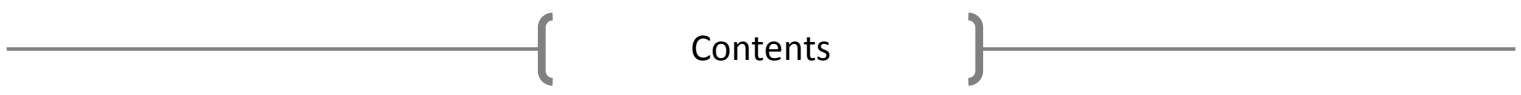




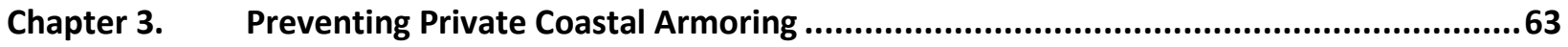

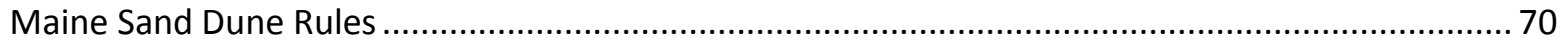

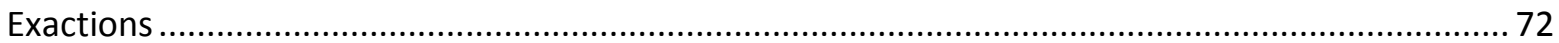

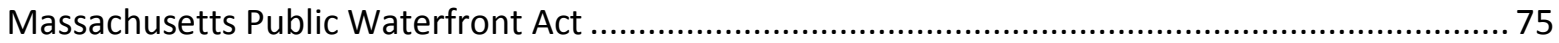

Lessons Learned

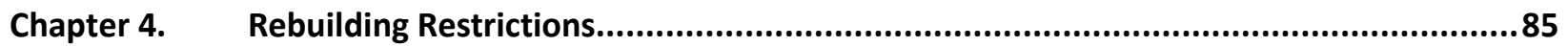

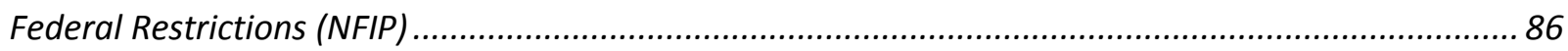

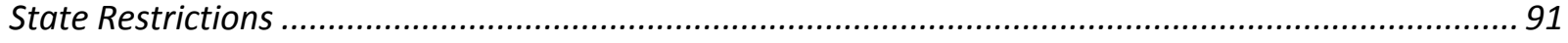

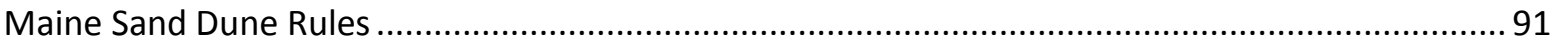

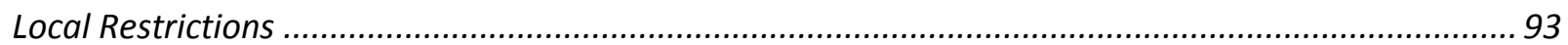

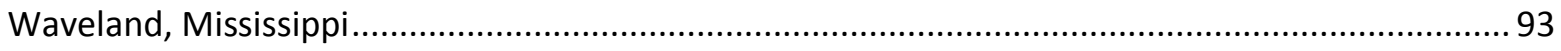

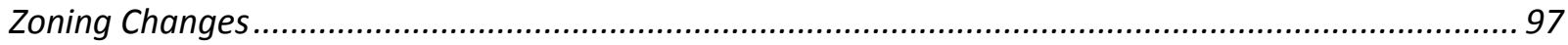

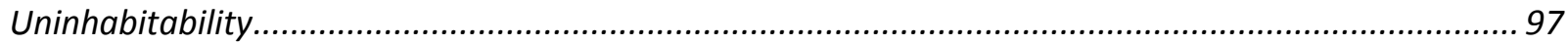

Lessons Learned

Chapter 5. Acquisition: Easements and Buyout Programs ...................................................103

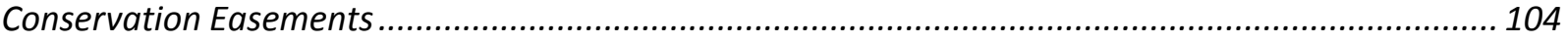

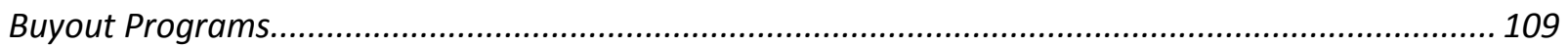

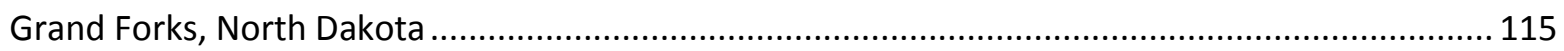

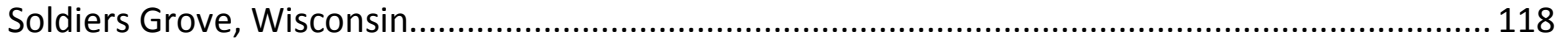

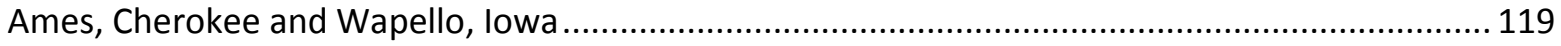

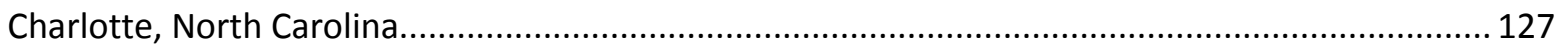

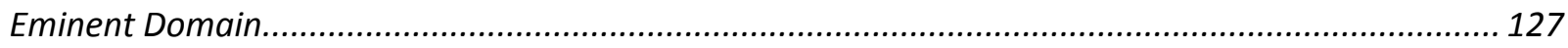

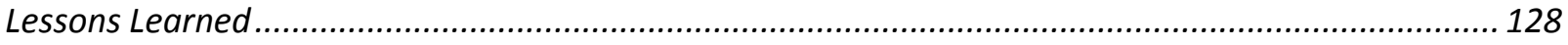

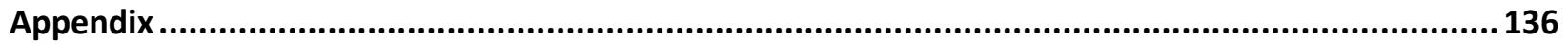

National Park Sample Conservation Easement ........................................................................ 136

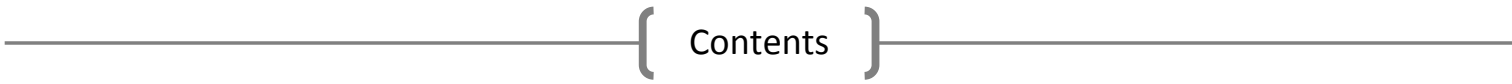




\section{ACRONYMS AND ABBREVIATIONS}

\begin{tabular}{|c|c|}
\hline AEC & Areas of Environmental Concern (North Carolina) \\
\hline BFE & Base Flood Elevation \\
\hline BW-12 & Biggert-Waters Flood Insurance Reform Act of 2012 \\
\hline CAMA & Coastal Area Management Act of 1974 (North Carolina) \\
\hline $\mathrm{CCC}$ & California Coastal Commission \\
\hline $\mathrm{CCCL}$ & Coastal Construction Control Line (Florida) \\
\hline CIP & Capital Investment Plan \\
\hline CMP & Coastal Management Program \\
\hline CZMA & Coastal Zone Management Act \\
\hline FEMA & Federal Emergency Management Agency \\
\hline GLO & General Land Office (Texas) \\
\hline LCP & Local Coastal Plan \\
\hline LUP & Land Use Plan \\
\hline MHW & Mean High Water \\
\hline MLW & Mean Low Water \\
\hline NFIP & National Flood Insurance Program \\
\hline NOAA & National Oceanic Atmospheric Administration \\
\hline SFHA & Special Flood Hazard Area \\
\hline SLR & Sea Level Rise \\
\hline TDR & Transfer of Development Rights \\
\hline TDC & Transfer of Development Credits \\
\hline TOBA & Texas Open Beaches Act \\
\hline
\end{tabular}




\section{COASTAL GEOGRAPHY}

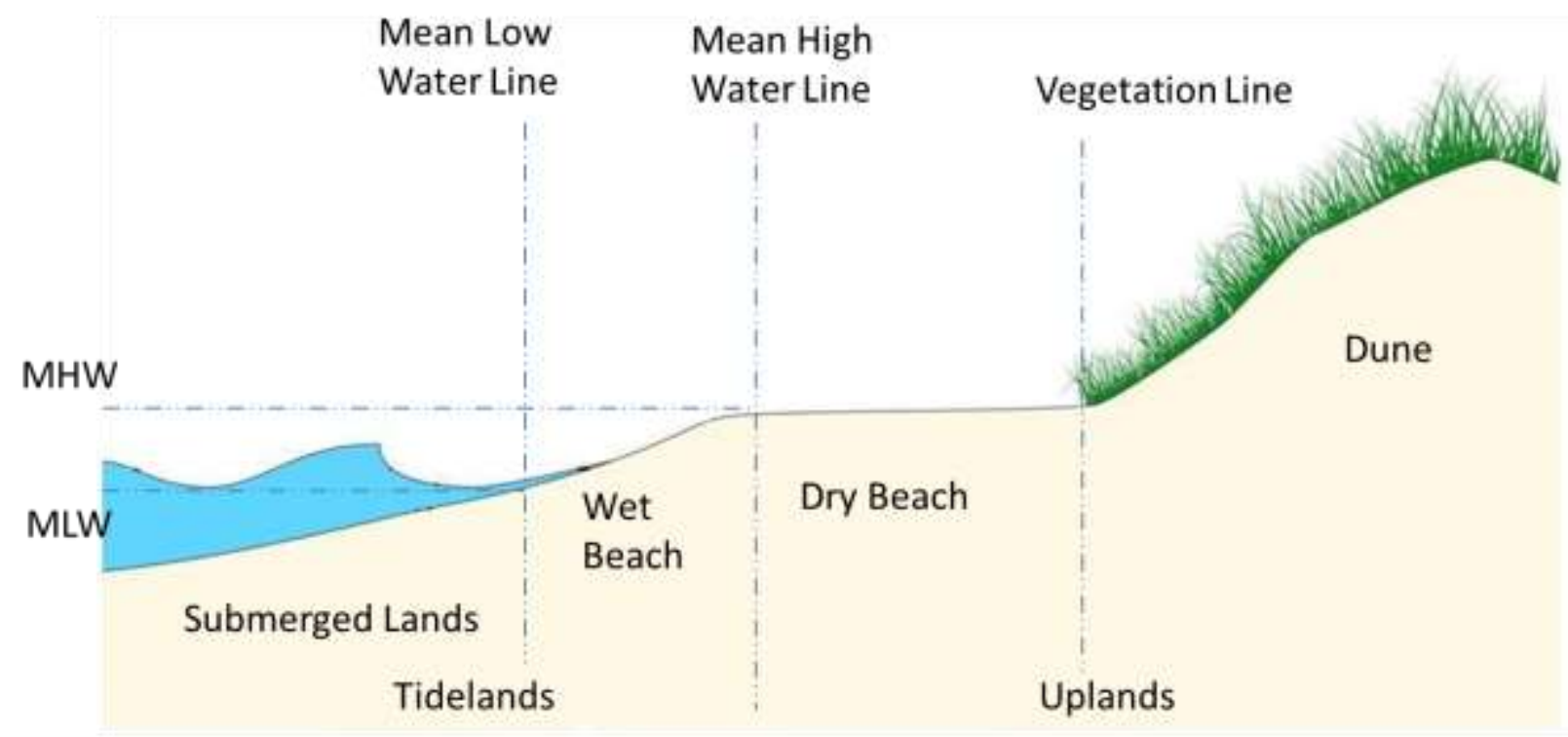

Image: EPA modified by CCCL

Dry Beach

Mean High Water

Mean High Water Line

Mean Low Water

Mean Low Water Line

Submerged Lands

Tidelands

Uplands

Vegetation Line

Wet Beach
Land between the $\mathrm{MHW}$ and the vegetation line

An average of all high water heights observed over the National Tidal Datum Epoch (19 years)

Intersection of the mean high water with the shore

An average of all low water heights observed over the National Tidal Datum Epoch (19 years)

Intersection of the mean low water with the shore

Lands covered by water at any stage of the tide; subject to public trust

Lands below the mean high water line and generally subject to public trust

Land above the mean high water mark and generally subject to private ownership

Line on the shore where vegetation begins; usually the line where recent storm activity reached

Land between the mean low water line and the mean high water line where the sand is repeatedly covered by water action; usually flat firm sand without vegetation

Definitions primarily from NOAA at http://shoreline.noaa.gov/glossary.html 


\section{EXECUTIVE SUMMARY}

Climate change will change the way we live. No longer will the environment be a static condition, a certainty upon which other variables depend. Rather, it will be a variable itself, and it will make us plan for the future like never before. Already we are beginning to see the effects of change along our coasts. Rising seas and more frequent hurricanes present a dynamic environment that threatens infrastructure long thought to be safe. Our cities are illprepared for the dangers of the next century. Fiscally, we are spending more and more to repair the damage. Long-term planning that accounts for climate change is needed to ensure that money spent today will reduce our future risk.

We have the opportunity to not only build resilience today but also prepare for the future, to build the infrastructure that will be the foundation for our cities in the next century. This will require innovation and new technologies. It will also require tough decisions. Some areas will be too vulnerable, despite our best efforts to hold back the sea. Infrastructure and homes will need to be moved away from the threat and the shore opened up to the public. The political obstacles to this strategy will be severe in many places, but consideration of them should begin now.

Numerous legal tools already exist to assist federal, state, and local governments in conducting managed retreat away from the most vulnerable coasts. Scattered publications, toolkits, and websites describe a broad range of legal, policy, and regulatory tools. These tools have, with little fanfare, been used by communities around the United States to implement managed retreat. This Handbook collects examples, case studies, and lessons learned from some of these early innovators in the hope that their lessons can inform future efforts to limit the exposure of our communities to coastal threats. The key legal issues raised by these examples are also discussed.

The Handbook is organized into five sections. Each describes a potential tool, provides examples and information, and then present the lessons learned for that tool. The tools described herein are not the only tools that can or should be used. In fact, significant innovation will likely be needed to address the novel challenges posed by climate change. The tools presented here are simply a selection of those that have been implemented and that can inform future actions. 


\section{COMPILED LESSONS LEARNED}

\section{Coastal Planning}

- Require planning at all levels. State mandates can improve local planning. Mandates are particularly effective when they identify clear prioritized goals, establish guidelines, and provide technical and financial support for local officials.

- Coordinate planning efforts. State and local governments need to coordinate their planning efforts and regulations. The goals at both levels need to be consistent and complementary in order to be effective.

\section{SETBACKS AND Rolling EASEMENTS}

- Using a combination of set distances and erosion rates for setbacks can provide minimum standards for areas that lack historic erosion data while also acknowledging that erosion and sea level rise are unlikely to affect the coastline evenly and that approaches in one area may be inappropriate in another.

- Plan for change. Setbacks should be designed to account for acceleration of erosion and sea level rise due to climate change. This can be done through the use of a safety factor or by planning for routine updating of the setback distances. Updating setback numbers would, ideally, not require a state level legislative response, which could be slow and delay necessary changes.

- Act now. Setbacks should be established as soon as possible in order to set property owners' expectations for the value of their property. Minimum lot sizes and "savings" clauses can also be used to avoid takings challenges. However, when structures are built seaward of the setback line due to a variance or permit, it should be clear that the owner takes on the financial risk and that no public funding will be provided for future relief or rebuilding.

- Combine tactics. Setbacks and rolling easements should be combined with a prohibition against coastal armoring in order to best implement a policy of managed retreat and protect the long-term health of beaches. Rolling easements must be combined with policies to prevent coastal armoring in order to be effective. Coastal armoring would both destroy the beach (thereby negating the public access purpose of the easement) and prevent the beach from rolling inland.

- Provide an enforcement mechanism to ensure that setback provisions are complied with and conduct regular evaluations to determine if the setbacks have been effective. 
- Be specific and explicit in legislation. A state wishing to implement a rolling easement should explicitly create one in state legislation. The initial creation of the easement may be considered a taking and require compensation, either monetary or through an offset. However, this compensation will be far less substantial than that required to purchase a home outright, and it will also secure public beach access.

- A rolling easement could also be acquired through the use of exactions. Private owners seeking to build or expand coastal properties could be required to allow a public easement as an offset to the negative externalities of coastal development.

- Use required disclosures to inform the public about risk. Sales of coastal property should include a disclosure requirement that informs prospective purchasers of the risks they face. This may not prevent takings litigation, but it will promote awareness of the costs of coastal living, which will assist in the implementation of further policies.

\section{Prohibiting Coastal Armoring}

- Take strong action. Coastal armoring has significant external costs to the long-term health of the shoreline and to public access to the coasts. A statewide prohibition or rigorous permitting requirements for coastal armoring is an effective method for preserving the coasts in those areas where feasible.

- Act quickly. Legislation and regulations should be enacted as soon as possible in order to limit the number and scope of existing structures that will be grandfathered in under the old permissive standards. Legislation should also limit, to the extent possible, the repair, rebuilding, and expansion of existing armoring. It should also transfer responsibility for funding the maintenance and replacement of existing structures to private landowners so that the costs of maintaining coastal armoring are internalized by coastal landowners.

- Use multiple tactics. Legislation, exactions, or agency policies prohibiting armoring should be coupled with setbacks, rolling easements, rebuilding restrictions and other managed retreat tools.

- Place the burden of proof on the landowner. Coastal development permits should not allow the existence of a seawall or other hard armoring to be sufficient evidence of the safety and stability of a development site. Placing the burden of proof on the landowner serves both to raise awareness with the development community and to save government resources. This will also limit harm in the case of a catastrophic event or failure of the armoring.

- Break the sea wall cycle whenever possible by preventing development that relies on the continued existence of coastal armoring. Such development will require substantial on- 
going funding to repair, rebuild, and expand coastal armoring to keep it safe. Managed retreat is not only about re-locating existing communities but also about preventing new development in vulnerable areas.

- Requiring landowners to promise not to build coastal armoring in order to receive a development permit can be a powerful coastal development tool and can be used broadly to accomplish managed retreat. When exactions are used, agencies should be careful in how they spell out the legitimate government interest that is being served by the exaction and should be sure that the burden on the landowner is proportionate to the benefit to the public.

- Pursuing mitigation fees for public harms resulting from hard armoring (such as lost access to public beaches) can provide needed revenue to pursue other managed retreat policies but should be used only in combination with other regulatory policies so as to avoid the appearance of selling the coast.

- When coastal armoring has proven ineffective, been substantially damaged by storms, or encroached on public lands governments can take this opportunity to require the removal of existing structures.

\section{REBUILDING RESTRICTIONS}

- Implement building restrictions and zoning decisions as soon as possible. These actions will only affect structures built after the regulations are put in place, so to avoid having buildings grandfathered in under old regulations, these need to be put in place promptly.

- Draft building and rebuilding requirements with future hazards in mind as well as current hazards. Sea level rise and climate change are likely to exacerbate the risks faced by coastal communities. Buildings in some $A$ zones will soon have to face $V$ zone-like hazards, so regulations should require buildings in $\mathrm{A}$ zones to comply with all $\mathrm{V}$ zone requirements. Consider implementing regulations not only for the 1 in 100 year flood but also for the 1 in 500 year flood.

- Prohibit repetitive repairs. Limit the number of times a building may be severely damaged by coastal events before it has to be removed entirely. This is an excellent way to prevent the costly public expenditures that will be required by repetitive losses along the coasts. Stating these requirements explicitly in advance of a disaster will put the community on notice.

- Educate the public about the risks associated with coastal living and the ways in which building restrictions address those risks. Conduct education campaigns when and where possibly. Partner with scientists and policy experts from universities, environmental groups, and other advocacy organizations. 
- Place the burden of proof on the private property owner. This will both require the property owner to educate him or herself about the risks facing the property and will reduce the resource burdens on government agencies.

- Coordinate zoning, building restrictions, setbacks, easements and other coastal management tools within a coherent coastal management plan to ensure that all tools are working towards complementary goals.

- Coordinate federal, state, and local building and rebuilding requirements to the extent possible. Conduct this review and coordination before a disaster so that property owners will be able to begin repairs as soon as possible after a disaster.

\section{ACQUISITION}

- Relocation is key. Municipalities and states considering a buyout program must consider where they want development to occur, identify those areas, and build in elements of their buyout program that assist homeowners in relocating to those desired areas. Some ways to do this are providing incentives for relocation within the district, providing assistance for down payments for low-income residents, and identifying areas of safe growth in a development plan. Areas for targeted development should be identified well in advance of a disaster. And new housing should be priced to be equally or less expensive than the housing that was acquired.

- Incentivize homeowners to remain nearby. This will not only assist in maintaining the tax base but also retain a greater sense of community. Government agencies can do this by offering bonus payments for homeowners to relocate nearby or by developing new housing areas.

- Move quickly. Buyout programs are most successful when initiated immediately after a natural disaster. Plans should be made and put in place in advance so that they can be implemented quickly after a disaster. Placing deadlines on accepting offers can be an effective measure to make homeowners make a decision. Staff should be dedicate staff to process applications quickly.

- Identify priority homes based on greatest vulnerability. Repetitive loss areas are particularly cost-effective areas for buyout programs.

- Make homeowners aware of the benefits of acquisition. This is true for both conservation easements and buyout programs. Conduct a targeted information campaign to educate homeowners on the dangers and costs associated with remaining in a vulnerable area. 
- Keep the program cost effective. Place a cap on the amount offered for homes or easements. Use a standard formula to determine property value in order to avoid long negotiation periods and hold-outs.

- Create floodplains. Attempt to buy large continuous areas of land in order to create floodplains that can act as barriers to future flooding. Return to areas after the fact and offer programs targeted at 'orphan houses.' Offer incentives for neighborhoods to move as a complete block. Target small locations: a program does not need to be large to be successful.

- Take the opportunity to invest in improvements. When buying properties, consider public spaces that would most improve the community. When rebuilding in safer locations, consider new building codes, solar power, and other design changes that would make those areas more desirable and resilient.

- Publicity and transparency are key. Working with NGOs can increase flexibility of programs, and working with the public builds trust and allows the community to have a voice in how the acquired land is used.

- Consider a combination of options such as acquisition through eminent domain coupled with the use of a conditional lease in order to lower costs. However, recognize that this path will provide protection only against the future harms of sea level rise and not against coastal storms that are affecting coastal properties even today.

- Be flexible and creative. Conservation easements can be designed to adapt to everyone's needs, making them more beneficial to landowners while still achieving the buffer needs. . 


\section{INTRODUCTION}

Ocean shorelines, with their economic resources and recreational opportunities, have long been coveted locations for development. The same proximity to the coast that makes development desirable also threatens those very structures: rising tides, eroding shores, and coastal storms all threaten property and public safety. As climate change accelerates rising sea levels and possibly worsens hurricanes and other storms, the threat posed by such hazards will increase. Ironically, development along the coasts impairs the shoreline's natural ability to withstand these same hazards.

As a result, many coastal communities are trapped in a cycle of risk in which they are developed, devastated by a natural event or disaster, and then rebuilt and repaired only to be struck again. ${ }^{1}$ As a classic example, Dauphin Island, Alabama, has been substantially destroyed ten times by hurricanes in the past forty years and yet, after being destroyed once again by Hurricane Katrina, commenced rebuilding. ${ }^{2}$ Dedication to community and resilience in the face of adversity are traits to be admired, but government officials must balance our natural tendency to persevere against the social and economic costs and risks to personal safety posed by continual development in vulnerable locations. Federal funding spreads the risk exposure of coastal living across a greater population, which means that individual property owners internalize less of the cost of living in such risky areas. ${ }^{3}$ Since 1979, Dauphin Island has received $\$ 80$ million in federal funding - more than $\$ 60,000$ per resident - plus an additional \$72 million in federal flood insurance payouts (although Dauphin Island residents have paid only $\$ 9.3$ million in premiums). ${ }^{4}$

Policy makers and the public at large are becoming increasingly aware of the expenses associated with repeated coastal disasters. Hurricane Sandy in the fall of 2012 cost \$65 billion. ${ }^{5}$ Hurricane Ike in 2008 came in at \$27 billion. Hurricanes Wilma and Rita cost \$16 billion each in 2005, not to mention Hurricane Katrina at \$125 billion. Hurricanes Ivan and Charley cost $\$ 14$ and $\$ 15$ billion respectively in $2004 .^{6}$ This list says nothing about a host of billion dollar storms in between, much less other types of disasters such as flooding and severe storms that cost billions every year (144 weather disasters over $\$ 1$ billion since 1980). Nor does it capture the personal costs: the loved ones lost, the people displaced for months on end, the personal belongings and memories destroyed, the communities disrupted.

If it seems that big disasters have been occurring more frequently in recent years, it may be true. According to the National Oceanic and Atmospheric Administration, the number of natural events that inflict at least \$1 billion in damage (adjusted for inflation) has risen from an average of two per year in the 1980s to more than ten per year since $2010 .^{7}$ And the federal 
government has begun playing a larger role in disaster relief, meaning more federal funding expended at each disaster. ${ }^{8}$ Between 2011 and 2013, Congress spent $\$ 136$ billion on disaster relief. ${ }^{9}$ In comparison, in 2013 , the federal government spent $\$ 65.7$ billion on education. ${ }^{10}$ These bills are only expected to increase as climate change exacerbates weather conditions, and public expenditures for repeated disaster relief are always controversial. ${ }^{11}$

In the past, government has promoted coastal development to encourage economic growth and expanded tax base. ${ }^{12}$ Increased development and larger, more expensive infrastructure raise the cost of each disaster. The three primary options to respond to a rising sea and increased threat of hurricanes are protection, accommodation, and retreat. Traditionally, governments and private owners have been reluctant to abandon coastal properties or to turn to flood-friendly uses. As a result, they have stressed the need for protective structures (such as seawalls and other forms of hard armoring) to defend coastal development from the sea. ${ }^{13}$ However, policy makers are becoming increasingly aware of the limitations and costs of hard armoring. Rather than rely solely on coastal armoring structures, policy makers will need to turn increasingly to land use reform and a policy of managed retreat from the shorelines. These policies avoid disasters by building resilience, preventing or limiting coastal development in vulnerable locations, and reducing the impact of coastal hazards on infrastructure. Such proactive non-structural solutions are often more cost effective than coastal armoring over the long-term as they do not require on-going maintenance, re-building, or repair. ${ }^{14}$ A long-term policy of managed retreat can limit a community's exposure to coastal hazards, save lives, and limit the expenditure of public funding on vulnerable infrastructure and response mechanisms. ${ }^{15}$

\section{Purpose of this Handbook}

Other academics have written about the numerous legal tools that are available to legislators and regulators to respond to coastal hazards and to conduct managed retreat. ${ }^{16}$ This Handbook builds on those works by providing practical advice drawn from examples of locations where managed retreat has already been conducted or is on-going. It describes legal principles and precedents that can serve as useful guides for the creation of new policies, and it identifies lessons learned and recommendations based on previous experiences. It is important for policy makers to recognize that managed retreat has been done before - sometimes successfully and sometimes not - and that we can learn from those examples to build a more resilient coast. 


\section{REFERENCES}

${ }^{1}$ See Travis Brennan, Redefining the American Coastline: Can the Government Withdraw Basic Services from the Coast and Avoid Takings Claims?, 14 OCEAN AND COASTAL LAW JOURNAL 101 (2008); Orrin H. Pilkey and Robert S. Young, Will Hurricane Katrina Impact Shoreline Management? Here's Why It Should, 21 JOURNAL OF COASTAL RESEARCH iii (2005); Oliver A. Houck, Rising Water: The National Flood Insurance Program and Louisiana, 60 TULANE LAW REVIEW 61, 63 (1985).

2 Rob Young and Andrew Coburn, Column: Sandy Reminds Us of Coastal Hazards, USA Today, Oct. 31, 2012, http://www.usatoday.com/story/opinion/2012/10/31/hurricane-sandy-new-york-new-jersey-coast-line/1669745; Justin Gillis and Felicity Barringer, As Coasts Rebuild and U.S. Pays, Repeatedly, the Critics Ask Why, NEW YoRK TIMES, Nov. 18, 2012, http://www.nytimes.com/2012/11/19/science/earth/as-coasts-rebuild-and-us-pays-again-criticsstop-to-ask-why.html?pagewanted=all (last visited Aug. 7, 2013).

${ }^{3}$ See, e.g., Raymond Burby et al., Sharing EnVIRONMENTAL RISKS: How to CONTROL Governments' LOSSES IN NATURAL DISASTERS (Westview Press, 1991).

4 See, e.g., Young and Coburn, supra note 2; Gillis and Barringer, supra note 2.

5 NOAA National Climatic Data Center, Billion-Dollar Weather/Climate Disasters, http://www.ncdc.noaa.gov/billions/events (last visited Aug. 7, 2013). NOAA calculates costs in terms of dollars that would not have been incurred had the event not taken place.

${ }^{6} / d$.

${ }^{7}$ Id. See also, Brad Plumer, The government is spending way more on disaster relief than anybody thought, THE WASHINGTON POST, Apr. 29, 2013, http://www.washingtonpost.com/blogs/wonkblog/wp/2013/04/29/thegovernment-is-spending-way-more-on-disaster-relief-than-anybody-thought (last visited Aug. 7, 2013).

${ }^{8}$ See, e.g., Jaison R. Abel, Jason Bram, Richard Deitz, and James Orr, How Will We Pay for Superstorm Sandy?, Federal Reserve BANK Of New York, Dec. 20, 2012, http://libertystreeteconomics.newyorkfed.org/2012/12/how-willwe-pay-for-superstorm-sandy.html (last visited Aug. 7, 2013); J. David Cummins, Michael Suher, and George Zanjani, Federal Financial Exposure to Natural Catastrophe Risk, in MEASURING AND MANAGING FEDERAL FINANCIAL RISK (NBER Conference Report, Chicago: University of Chicago Press, 2010).

${ }^{9}$ Daniel J. Weiss and Jackie Weidman, Disastrous Spending: Federal Disaster-Relief Expenditures Rise amid More Extreme WEATHER (Center for American Progress, 2013), at 1.

10 New American Foundation, Education in the Federal Budget, Jun. 21, 2013, http://febp.newamerica.net/background-analysis/education-federal-budget (last visited Aug. 7, 2013).

${ }^{11}$ See, e.g., Rick Ungar, Oklahoma's Two GOP Senators Repeatedly Opposed Disaster Relief for Others in Need, may 21, 2013, http://www.forbes.com/sites/rickungar/2013/05/21/oklahomas-two-gop-senators-repeatedlyopposed-disaster-relief-for-others-in-need; Brad Plumer, Why the fights over disaster relief in Congress keep getting worse, THE WASHINGTON POST, Jan. 2013, http://www.washingtonpost.com/blogs/wonkblog/wp/2013/01/04/why-the-fights-over-disaster-relief-incongress-keep-getting-worse; Klaus Jacob, Time for Tough Question: Why Rebuild?, The Washington Post, Sep. 6, 2005, http://www.washingtonpost.com/wp-dyn/content/article/2005/09/05/AR2005090501034.html(last visited Aug. 7, 2013).

${ }^{12}$ See e.g., NOAA, State of the Coast: Economy, http://stateofthecoast.noaa.gov/coastal economy (stating that in 2011, 45\% of the U.S. gross domestic product was generated in coastal counties); NANCY S. PHILIPPI, FLOODPLAIN Management - Ecologic And Economic Perspectives 29-30 (1996) (describing economic interests associated with coastal communities); John R. Logan and Harvey L. Molotoch, Urban Fortunes: The Political ECONOMY of Place (Berkeley, CA: University of California Press, 1987) (describing local political pressure for economic growth as 
motive for not limiting development in hazardous areas); Leonard Ruchelman, Natural Hazard Mitigation and Development: An Exploration of the Roles of Public and Private Sectors, in MANAGING DISASTER: STRATEGIES AND PeRSPECTIVES (Louise Comfort, ed., Durham, NC: Duke University Press, 1988).

${ }^{13}$ See, e.g., NATIONAL RESEARCH COUNCIL, MANAGING COASTAL EROsION 29, 56-61 (1990) (describing the main methods of erosion control as hard armoring projects including dams, groins, seawalls, revetments, and breakwaters); NOAA, State of the Coast: Shoreline Armoring: The Pros and Cons, http://stateofthecoast.noaa.gov/shoreline/shoreline armoring.html (stating that millions of federal, state, and private dollars have been expended annually on shore armoring and protection).

${ }^{14}$ See generally U.S. Environmental Protection Agency (EPA), Anticipatory Planning for Sea-Level Rise Along the Coast of Maine at 5-1 - 5-2 (Sep. 1995). For a discussion of the long-term costs to each state from climate change impacts, see the fifty state reports prepared by the American Security Project, Pay Now, Pay Later (2011) available at http://americansecurityproject.org/issues/climate-energy-and-security/climate-change/pay-now-pay-later (last visited Aug. 7, 2013).

${ }^{15}$ See generally Brower, David J. Brower et al., Reducing Hurricane and Coastal Storm Hazards Through Growth Management: A Guidebook for North Carolina Coastal Localities at 29-30 (1987).

${ }^{16}$ See, especially, J. Grannis, Adaptation Tool Kit: Sea LeVel Rise And Coastal Land Use (Georgetown Climate Center, 2011); J. Peter Byrne \& J. Grannis, Coastal Retreat Measures, in The LAW of Adaptation to Climate Change (M. Gerrard \& K. Kuh, eds., 2012). 


\section{TABle of CoAstal Management Tools}

Numerous legal and policy tools are available to promote coastal managed retreat, not all of which are discussed in depth in this Handbook. This table provides a brief overview of available tools, as consolidated from other sources in the managed retreat literature. See, especially:

J. Grannis, adaptation tool Kit: Sea level Rise and Coastal land Use (Georgetown Climate Center, 2011).

J. Peter Byrne \& J. Grannis, Coastal Retreat Measures, in The LAW of AdAPTAtion to Climate Change (M. Gerrard \& K. Kuh, eds., 2012).

\begin{tabular}{|c|c|c|}
\hline Tool & Description & Example \\
\hline $\begin{array}{l}\text { Climate } \\
\text { Adaptation } \\
\text { Plans }\end{array}$ & $\begin{array}{l}\text { Climate adaptation plans can address } \\
\text { coastal hazards as part of a state-wide or } \\
\text { local adaptation effort }\end{array}$ & $\begin{array}{l}\text { California Climate Adaption } \\
\text { Strategy; Florida Governor's } \\
\text { Action Team on Energy and } \\
\text { Climate Change }\end{array}$ \\
\hline $\begin{array}{l}\text { Development } \\
\text { Plans }\end{array}$ & $\begin{array}{l}\text { Identifying areas for priority development } \\
\text { and areas for retreat can promote } \\
\text { managed retreat as part of a larger } \\
\text { development strategy }\end{array}$ & $\begin{array}{l}\text { Maryland Smart Growth } \\
\text { Initiative }\end{array}$ \\
\hline $\begin{array}{l}\text { Hazard } \\
\text { Mitigation Plans }\end{array}$ & $\begin{array}{l}\text { Incorporate increased hazards from } \\
\text { climate change into HMPs, and then use } \\
\text { the HMPs to guide comprehensive plans/ } \\
\text { zoning process }\end{array}$ & $\begin{array}{l}\text { FEMA-Approved State Hazard } \\
\text { Mitigation Plans - Colorado's } \\
\text { Drought Plan and California's } \\
\text { State Hazard Mitigation Plan }\end{array}$ \\
\hline $\begin{array}{l}\text { Coastal } \\
\text { Management } \\
\text { Plans }\end{array}$ & $\begin{array}{l}\text { Coastal management plans integrate a } \\
\text { variety of managed retreat policies into a } \\
\text { comprehensive and coherent plan to } \\
\text { guide development }\end{array}$ & Texas Coastal Management Plan \\
\hline $\begin{array}{l}\text { Capital } \\
\text { Improvement } \\
\text { Plans / Land } \\
\text { Use Plans }\end{array}$ & $\begin{array}{l}\text { Use capital improvement plans to study } \\
\text { the vulnerability of their infrastructure to } \\
\text { projected climate change impacts and } \\
\text { then decrease investment in } \\
\text { infrastructure in vulnerable areas }\end{array}$ & $\begin{array}{l}\text { Maryland Growth Act and Smart } \\
\text { Growth Imitative; California } \\
\text { Coastal Act }\end{array}$ \\
\hline $\begin{array}{l}\text { Transportation } \\
\text { Plans (and other } \\
\text { Utility or } \\
\text { Agency Plans) }\end{array}$ & $\begin{array}{l}\text { Incorporate managed retreat into siting } \\
\text { decisions in federally-mandated state } \\
\text { transportation plans; allocate } \\
\text { infrastructure to less vulnerable areas }\end{array}$ & $\begin{array}{l}\text { California Department of } \\
\text { Transportation Guidance (2011): } \\
\text { instructed staff on how to } \\
\text { assess sea-level rise risks when } \\
\text { planning infrastructure projects }\end{array}$ \\
\hline $\begin{array}{l}\text { Flood Insurance } \\
\text { Reforms }\end{array}$ & $\begin{array}{l}\text { Requiring insurance in flood-prone areas } \\
\text { can protect homeowners and } \\
\text { government funds by providing other } \\
\text { means of relief; it can also signal the true } \\
\text { costs of coastal living }\end{array}$ & $\begin{array}{l}\text { National Flood Insurance } \\
\text { Program }\end{array}$ \\
\hline
\end{tabular}




\begin{tabular}{|c|c|c|}
\hline Tool & Description & Example \\
\hline Downzoning & $\begin{array}{l}\text { Limit potential uses and intensity of use } \\
\text { in areas vulnerable to the effects of } \\
\text { climate change to decrease development } \\
\text { potential }\end{array}$ & $\begin{array}{l}\text { Connecticut Coastal } \\
\text { Management Act }\end{array}$ \\
\hline Zoning Overlay & $\begin{array}{l}\text { Provide an additional layer of zoning } \\
\text { requirements in specialized areas such as } \\
\text { coastal hazard areas }\end{array}$ & Greenwich, Connecticut \\
\hline Setbacks & $\begin{array}{l}\text { Require new development to be sited } \\
\text { upland to avoid flooding; base setbacks } \\
\text { on erosion rates or sea level rise to create } \\
\text { a rolling setback }\end{array}$ & $\begin{array}{l}\text { California Coastal Act; Maine } \\
\text { Sand Dune Rules; Kaua'i, Hawaii }\end{array}$ \\
\hline $\begin{array}{l}\text { Building and } \\
\text { Rebuilding } \\
\text { Restrictions }\end{array}$ & $\begin{array}{l}\text { Require strict construction standards in } \\
\text { vulnerable areas; limit the extent or } \\
\text { number of repairs after disasters }\end{array}$ & $\begin{array}{l}\text { Maine Sand Dune Rules; South } \\
\text { Carolina Beach Front } \\
\text { Management Act; Florida } \\
\text { Coastal Construction Control } \\
\text { Line }\end{array}$ \\
\hline $\begin{array}{l}\text { Building } \\
\text { Moratoria }\end{array}$ & $\begin{array}{l}\text { Impose a temporary moratorium on new } \\
\text { building permits while regulators update } \\
\text { comprehensive plans and zoning schemes } \\
\text { to account for projected sea level rises } \\
\text { and other climate change impacts }\end{array}$ & $\begin{array}{l}\text { Florida } 1989 \text { two-year } \\
\text { moratorium on building on } \\
\text { coastal islands; Nags Head, } \\
\text { North Carolina }\end{array}$ \\
\hline Exactions & $\begin{array}{l}\text { Grant development permits with retreat } \\
\text { conditions (e.g. no armoring, setback } \\
\text { requirement, rolling easement) }\end{array}$ & $\begin{array}{l}\text { California Coastal Commission } \\
\text { prohibition on armoring }\end{array}$ \\
\hline Condemnation & $\begin{array}{l}\text { Establish policy of declaring homes too } \\
\text { close to shore (and therefore exposed to } \\
\text { erosion and storms) as being unsafe for } \\
\text { habitation }\end{array}$ & $\begin{array}{l}\text { Pacifica, California } \\
\text { (condemnation due to erosion } \\
\text { of coastal bluffs) }\end{array}$ \\
\hline $\begin{array}{l}\text { Private } \\
\text { Information } \\
\text { Disclosure }\end{array}$ & $\begin{array}{l}\text { Require property sellers to disclose risks } \\
\text { to the property from climate change, sea } \\
\text { level rise, and erosion }\end{array}$ & $\begin{array}{l}\text { South Carolina: S.C. Code Ann. } \\
\text { Section 48-39-330 } \\
\frac{\text { California: Cal. Civ. Code Section }}{1103.2}\end{array}$ \\
\hline $\begin{array}{l}\text { General } \\
\text { Information } \\
\text { Disclosure }\end{array}$ & $\begin{array}{l}\text { Make publicly available all the maps and } \\
\text { models used to create state climate } \\
\text { change adaption plans; identify } \\
\text { vulnerabilities and risks }\end{array}$ & $\begin{array}{l}\text { New York City report "A } \\
\text { Stronger, More Resilient New } \\
\text { York" }\end{array}$ \\
\hline $\begin{array}{l}\text { Buyouts } \\
\text { (Acquisition in } \\
\text { Fee) }\end{array}$ & $\begin{array}{l}\text { Acquire land in vulnerable areas and } \\
\text { convert it to open space to protect } \\
\text { remaining infrastructure and buildings }\end{array}$ & $\begin{array}{l}\text { Ames County, lowa; Grand } \\
\text { Forks, North Dakota; Soldier's } \\
\text { Grove, Wisconsin }\end{array}$ \\
\hline
\end{tabular}




\begin{tabular}{|l|l|l|}
\hline \multicolumn{1}{|c|}{ Tool } & \multicolumn{1}{|c|}{ Description } & \multicolumn{1}{|c|}{ Example } \\
\hline $\begin{array}{l}\text { Conservation } \\
\text { Easements }\end{array}$ & $\begin{array}{l}\text { Acquire an easement on all or part of the } \\
\text { vulnerable property such that landowner } \\
\text { agrees to limit development in specified } \\
\text { manner }\end{array}$ & $\begin{array}{l}\text { Maryland Environmental Trust; } \\
\text { Wapello, lowa; National Park } \\
\text { Service }\end{array}$ \\
\hline $\begin{array}{l}\text { Transferable } \\
\text { Development } \\
\text { Credits }\end{array}$ & $\begin{array}{l}\text { Sever development rights from property } \\
\text { ownership; landowners in vulnerable } \\
\text { areas can sell their development rights to } \\
\text { landowners in less-vulnerable areas } \\
\text { seeking to expand }\end{array}$ & $\begin{array}{l}\text { City of Malibu, California, Local } \\
\text { Coastal Program; Collier } \\
\text { County, Florida }\end{array}$ \\
\hline Tax Incentives & $\begin{array}{l}\text { Base property tax assessments on current } \\
\text { use values, instead of fair market values } \\
\text { (which would be influenced by } \\
\text { developers), making it more cost- } \\
\text { effective for landowners to hold onto } \\
\text { undeveloped land }\end{array}$ & $\begin{array}{l}\text { Virginia Conservation Easement } \\
\text { Tax Incentives }\end{array}$ \\
\hline
\end{tabular}


Columbia Center for Climate Change Law

8| P a g e 


\section{PRELIMINARY MATTERS}

Coastal management is a rich and complicated area of policy and regulation. No one publication could thoroughly address all of the related laws and policies. However, two areas that require some background familiarity are the National Flood Insurance Program (NFIP) and constitutional takings challenges. Neither will be addressed comprehensively, but an overview is included for those readers not familiar with the challenges presented and should serve as a reference for background information.

\section{NATional FLOOD InSURANCE PROGRAM}

In 1968, Congress created the NFIP to provide subsidized insurance to communities in areas particularly vulnerable to floods. Private insurance rates that reflected the actual extent of the flood

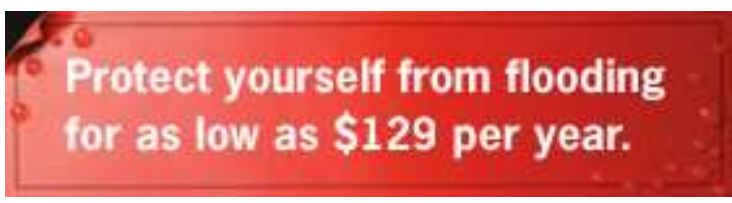
risk were becoming prohibitively expensive and communities along river and coastal shores were left exposed to risk from storms and floods. Federally subsidized insurance was meant to enable coastal development while promoting hazard mitigation efforts. However, the program has been criticized for promoting vulnerable development and spending federal tax dollars in an unsustainable manner. The Biggert-Waters Flood Insurance Reform Act of 2012 (discussed below) may address some of these concerns as it is implemented over the coming years. Through mapping, insurance rate-setting, and developing minimum floodplain regulations, the NFIP has the potential to promote managed retreat and hazard mitigation.

The Federal Emergency Management Agency (FEMA) administers the program. FEMA designates Special Flood Hazard Areas (SFHAs) as those areas expected to be flooded during a 100 year flood. ${ }^{17^{\dagger}}$ Local communities located within or partially within SFHAs must develop floodplain management plans to address potential floods and buildings must meet minimum construction requirements in order to qualify for federally subsidized insurance. ${ }^{18}$

Despite these requirements, coastal storms caused significant damage to shoreline properties. Many buildings were not built according to NFIP standards and required costly repairs after being damaged - costs that were not met by the low premiums. Some premiums did not reflect the true risks of flooding. When building standards changed, or the risk of flooding increased, homes were "grandfathered" in - they paid according to what the risk was when the home was built rather than according to the current level of risk. In addition, the mandatory requirement for homeowners with a federally backed mortgage to purchase flood

\footnotetext{
*Images: FEMA Flood Facts.

${ }^{+}$It is important to be clear that a 100 year flood is not a flood that occurs once every 100 years. Rather, it is a flood that has a $1 \%$ chance of occurring (or being exceeded) every year.
} 
insurance was not strictly enforced. ${ }^{19}$ This meant that during times of disaster many homeowners who had not purchased insurance still received federal aid.

Flood insurance is

mandatory if you

live in a high-risk

area and have a

mortgage from a

federally regulated

or insured lender.

All of this meant that NFIP was spending more money that it recovered through premiums. After the 2005 storm season, NFIP had an estimated \$23 billion in liabilities, far exceeding the \$2.2 billion in premiums earned annually. ${ }^{20}$ As of September 2011, the NFIP had a debt of $\$ 17.75$ billion and was widely considered financially unsound. ${ }^{21}$ The NFIP requires regular re-authorization from Congress, but Congress has at times been slow to reauthorize the floundering program, which left homeowners who needed insurance to get mortgages in limbo. ${ }^{22}$ In order to address these issues, the Biggert-Waters Flood Insurance Reform Act was passed in July 2012.

\section{Biggert-Waters Flood Insurance Reform Act of 2012}

The Biggert-Waters Flood Insurance Reform Act (BW-12) $)^{23}$ extended the NFIP for five years and made modifications to the program's structure. Some of the key provisions of BW-12 include raising insurance premiums, creating a technical mapping council, and studying the possibility of transferring flood risk to the private sector.

To address NFIP's ongoing financial problems, BW-12 phases out subsidized rates for newly purchased properties, lapsed policies, and new policies covering properties for the first time. ${ }^{24}$ This will occur slowly: new rates will increase 20\% per year starting in 2014 until the full risk is reflected in the rate. ${ }^{25}$ A portion of the $20 \%$ of existing policyholders that pay subsidized rates (approximately 1.12 million of the 5.6 million policyholders) will see a $25 \%$ annual premium increase until full-risk premiums are reached. ${ }^{26}$ BW-12 also removes grandfathered rating, which means that homeowners will be required to pay premiums based on the latest risk assessment and maps rather than the risk assessments and maps that were in place at the time of construction. For those that are affected, this could result in substantial increase in their premiums. Homes built before the first Flood Insurance Rate Map (Pre-FIRM) was created for their area will see a 16 to $17 \%$ increase. ${ }^{27}$ For a single-story structure in high risk, non-coastal $\mathrm{AE}$ zone, a $\$ 250,000$ home might see the following changes in policy depending on the elevation of the property: ${ }^{28}$

\begin{tabular}{|l|c|c|}
\hline & $\begin{array}{l}\text { Subsidized Premium Rates } \\
\text { Before BW12 }\end{array}$ & $\begin{array}{l}\text { Premium Rates Elimination of } \\
\text { Subsidies (Oct 1, 2013) }\end{array}$ \\
\hline $\begin{array}{l}\text { Lowest floor of property is 4 } \\
\text { feet above base flood elevation }\end{array}$ & $\$ 3,600$ & $\$ 553$ \\
\hline $\begin{array}{l}\text { Lowest floor of property is at } \\
\text { base flood elevation }\end{array}$ & $\$ 3,600$ & $\$ 1,815$ \\
\hline $\begin{array}{l}\text { Lowest floor of property is 4 } \\
\text { feet below base flood elevation }\end{array}$ & $\$ 3,600$ & $\$ 10,723$ \\
\hline
\end{tabular}



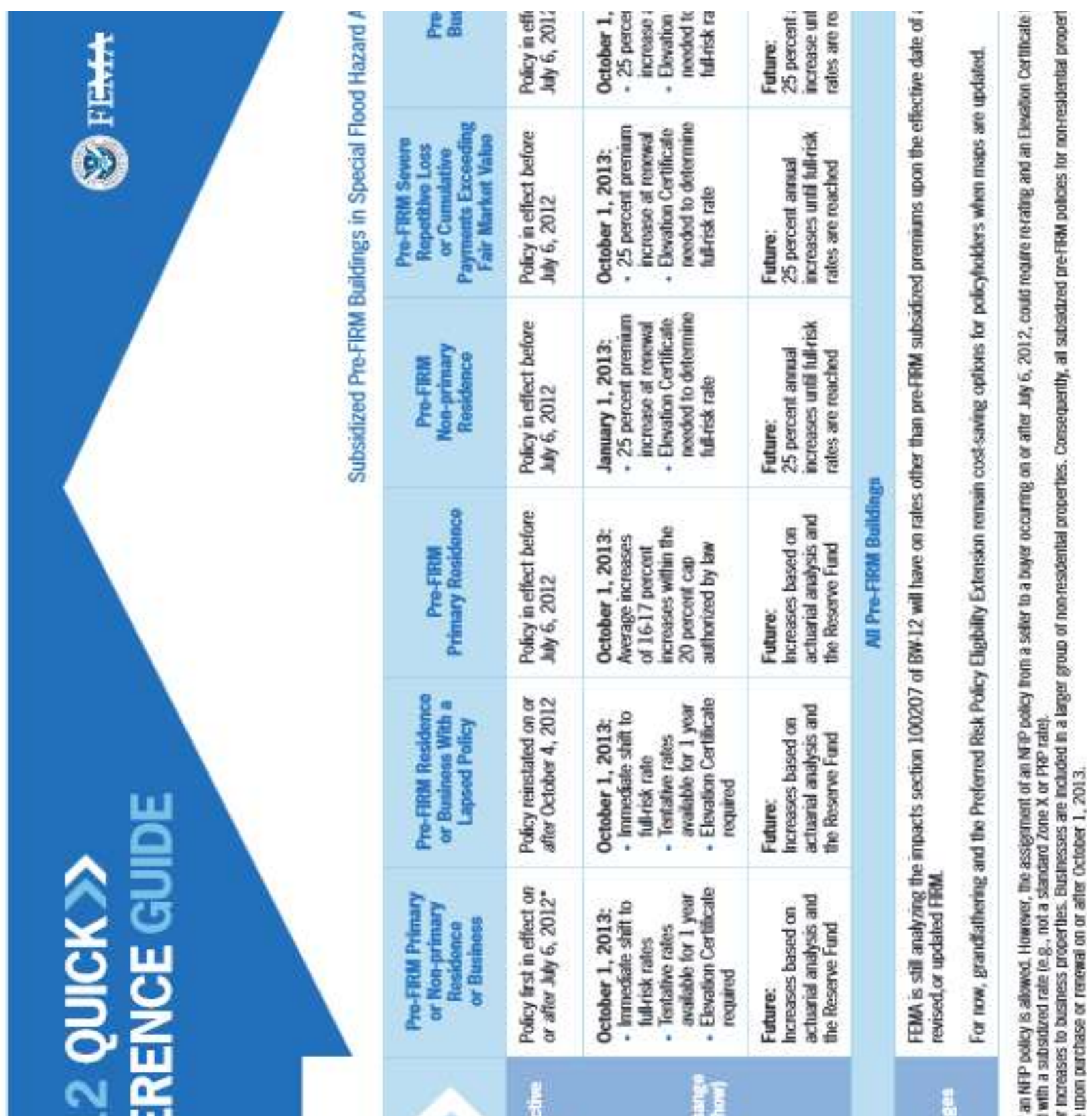

Table from FEMA Quick Reference Guide, September, 2013.

It is important to note that in the table above, the homes at or above base flood elevation actually see a reduction in their insurance premiums. Moreover, these changes will not be implemented immediately. Primary home owners in some cases will keep their subsidized rates until or unless the policy lapses, the property is sold, the property suffers repeated damage, or a new policy is purchased. ${ }^{29}$ Even so, as a result of these changes, developers and new buyers may be discouraged from purchasing homes in vulnerable areas. 


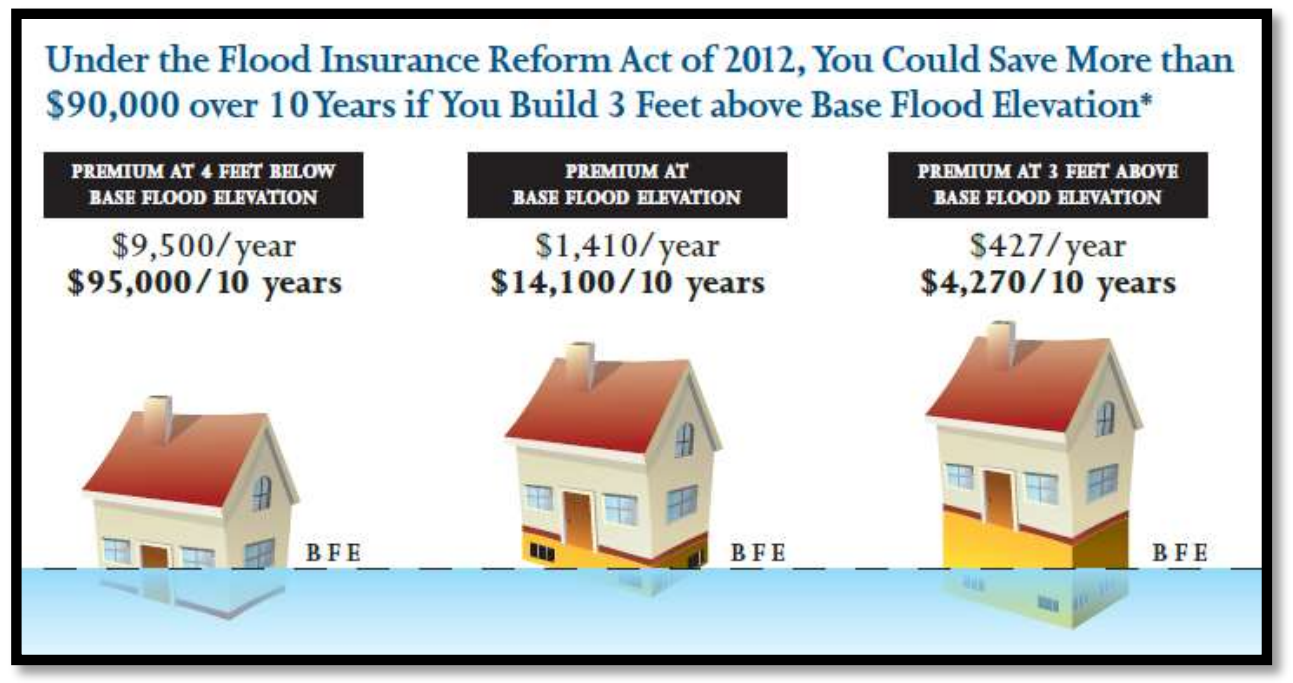

Graphic:

FEMA

Opponents of managed retreat argue that raising insurance premiums will mean that only wealthy individuals are able to live along the coasts. However, the $25 \%$ increase will only affect non-primary residents (e.g., second homes and summer homes), businesses, and severe loss properties. $^{30}$ The second-home owners and at least some of the businesses are less likely to be the backbone of neighborhoods and communities that government funding seeks to preserve. As for severe loss properties, proponents of managed retreat argue that it is unfair to use tax dollars paid by inland residents to allow other citizens to live along the coasts; and that subsidizing housing for homeowners in vulnerable locations means placing those families and communities who can least afford to lose their homes and possessions in danger from floods and storms.

What is certain is that increased NFIP premiums will create political pressure for state and local governments to further subsidize coastal living. Government officials should study the long-term costs and benefits of promoting coastal development in vulnerable areas before committing public funds.

In addition to changing premium rates, $\mathrm{BW}-12$ also creates a technical mapping advisory council that oversees improvements of floodplain maps to ensure premiums can more accurately reflect risk. ${ }^{31}$ These are important as outdated flood maps are often relied on by policy makers, leading to hazard mitigation plans that do not reflect the true scope of the risk, and by homebuyers and their lenders.

Nearly $20 \%$ of

flood insurance

claims come from

moderate-to-low

risk areas.

BW-12 also allows the federal government to study the possibility of transferring some of the flood risk from the nation to the private sector through reinsurance purchasing. ${ }^{32}$ Reinsurance would allow the government to make a payment to private insurance companies, who would then assume future flood losses sustained from disasters. ${ }^{33}$ This assumes that private insurance companies will be willing to enter this arena, which is not certain. 


\section{FURTHER READING}

Raymond Burby, Flood Insurance and Floodplain Management: The U.S. Experience, 3 ENVIRONMENTAL HAZARDS 111 (2001).

Howard Kunreuther and Gilbert White, The Role of the National Flood Insurance Program in Reducing Losses and Promoting Wise Use of Floodplains, 95 Journal OF CONTEMPORARY WATER RESEARCH AND EdUCATION 6 (2011).

Jessica Grannis, Analysis of How the Flood Insurance Reform Act of 2012 (H.R. 4348) May Affect State and Local Adaptation Efforts, Georgetown Climate Center (Aug. 1, 2012), available at http://www.georgetownclimate.org/sites/default/files/Analysis\%20of\%20the\%20Flood\%20Insurance\%2 OReform\%20Act\%20of\%202012.pdf.

Mary Myers, The National Flood Insurance Program as a Non-Structural Mitigation Measure,

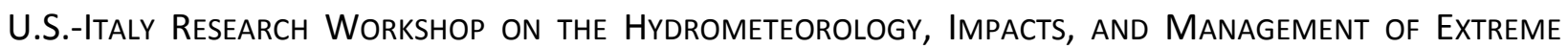
Floods, Perugia, Italy, November 1995, available at http://www.engr.colostate.edu/ jsalas/usitaly/papers/45myers.pdf.

\section{Constitutional TAKings \& CoMPEnSATION}

The Fifth Amendment of the U.S. Constitution prohibits the government from taking private property without providing just compensation. This is most classically embodied in a physical taking, when the government takes control of a parcel of land through eminent domain for a public purpose. However, it may also apply to laws and regulations that proscribe or restrict development. This section will briefly describe some of the most notable case law on takings.

It is important to note that the focus of takings litigation is not whether or not the government is allowed to pass a law or adopt a regulation but whether or not the government will be required to compensate the landowner. Managed retreat may not be feasible if it requires substantial payments to private landowners, so much of the discussion within this handbook will focus on whether or not the government is required to pay. However, even in cases where an action might be constituted a taking, it must be clear that government can still choose to enact that regulation; it will simply be required to pay the landowner.

\section{Permanent Physical Occupation}

Legislatures cannot enact a managed retreat measure that amounts to a permanent physical occupation of private property without compensating the landowners. A "physical occupation" applies not only when the government takes complete control over the property 
but also when the government requires the landowner to permit someone or something to access her property.

This principle derives from the case Loretto v. Teleprompter Manhattan CATV Corp., 458 U.S. 419 (1982). In Loretto, a New York law required landlords to allow cable companies to place equipment outside their apartment buildings on a permanent basis. The court held that the law worked as a taking, and the principle stands. An easement which allows the public access to a portion of a beach property amounts to a physical occupation and is therefore a taking. This applies when an easement is first created, not when the easement shifts (see Chapter 2 on Rolling Easements).

\section{$\underline{\text { Restrictions, Exactions and Public Dedication of Private Property }}$}

The government can use its power to approve and deny development construction and other permits as a mechanism to impose development restrictions and to obtain exactions. The government can restrain an owner from building a seawall (see Chapter 3 on Preventing Armoring) or limit the number of times an owner could rebuild after a coastal storm (see Chapter 4 on Rebuilding Restrictions) by granting a development permit only if the builder agrees to the government's terms. These are not traditional physical occupations, but they may still face takings challenges. For example, an exaction that requires an owner to dedicate a portion of his property for a public purpose or to grant an easement for public access to her property may be considered a physical taking. In order avoid begin considered a taking, the restriction or exaction must serve a legitimate public interest (such as public health, safety, and welfare) and must meet two further criteria:

- Rough Proportionality: In 1994 the Court first articulated the "rough proportionality" requirement in Dolan v. City of Tigard. That is, the burden placed on the private owner must be in some way proportional to the benefit being conferred on the public. ${ }^{34}$

- Essential Nexus: According to the U.S. Supreme Court's 1987 decision in Nollan v. California Coastal Commission, ${ }^{35}$ the government may only condition the granting of a permit on an exaction if the action demanded of the private owner serves the same purpose as a permit denial would have served. The government cannot condition a permit on the performance of some unrelated task.

Government officials must be mindful of the limits of restrictions on use, exactions and dedications of private property for public purposes, but, used prudently, these devices can be a valuable part of the legislator's managed retreat toolkit. Government can use exactions and conditions on building permits to obtain transfers of land or to obtain easements that allow government agencies to actively manage portions of land in problematic areas. According to the Supreme Court, "Insisting that landowners internalize the negative externalities of their conduct is a hallmark of responsible land-use policy, and we have long sustained such regulations against constitutional attack." ${ }^{36}$ However, agencies should be careful how they justify the proportionality of their demands and the connection between the externalities 
caused by the developer's proposed project and the mitigating activity proposed by the agency. $^{37}$

\section{The Koontz Complication}

In June 2013, the Supreme Court issued a ruling in Koontz v. St. Johns River Water Management District ${ }^{38}$ that may require government agencies to be even more careful in how they justify imposing conditions on building permits. In Koontz, a landowner held a 14.9 acre wetlands property and sought a permit to develop a 3.7 acre portion. The Management District was unsatisfied with the offer and gave Koontz two options: either develop one acre and conserve the remaining, or proceed with developing all 3.7 but pay for improvements on other wetlands some miles away. The owner rejected both choices and the permit was denied. Koontz claimed that the denial violated his property rights.

The U.S. Supreme Court held that government's conditions must meet the tests set forth in Nollan/Dolan even when the government denies the permit: "It makes no difference that no property was actually taken in this case. Extortionate demands for property in the land-use permitting context run afoul of the Takings Clause not because they take property but because they impermissibly burden the right not to have property taken without just compensation." 39 Moreover, an exaction that requires a landowner to pay money (rather than dedicate some portion of her land to public use) may still be a taking if it runs afoul of the Nollan/Dolan tests. The Koontz decision was based on the tradition that the government "may not deny a benefit to a person because he exercises a constitutional right." 40 In this case, the government cannot deny Koontz a building permit because he objected to an unconstitutional demand by the government. That would be an unconstitutional condition.

The dissent noted that this ruling might place a significant burden on government's ability to obtain exactions. But, as the Court noted, an "unconstitutional condition" is not the same as a taking, so Koontz is not entitled to compensation under the Fifth Amendment - he did not lose his property and he was not actually required to pay for improvements on other land. He may still be entitled to payment under Florida state law, but that is a matter yet to be determined by the Florida state courts. In fact, the full impact of Koontz on the managed retreat picture is unsettled. It may be that, in practice, Koontz will be a modest extension of the rules previously established in Nollan/Dolan, requiring clearer justifications for exactions. However, any agency seeking exactions must be mindful of how the case is being interpreted in its state courts and how that might affect the agency's proposed process.

\section{Regulatory Takings}

In some cases, government regulations affect property so significantly that the regulation is deemed to be effectively equivalent to an exercise of eminent domain power, even though the owner retains title to the property. A brief discussion of regulatory takings is provided here. Further discussion and examples as they relate to floodplain management can be found in: 
Jon A. Kusler, No Adverse Impact: Floodplain Management and the Courts, AsSOCIATION OF STATE FLOOdPLAIN MANAGERS (2004), http://www.floods.org/NoAdverselmpact/NAI AND THE COURTS.pdf.

\section{Deprivation of All Economic Value}

If a proposed regulation will deprive an owner of all economic value in the property, the regulation may run afoul of the holding of Lucas v. South Carolina Coastal Council (1992), ${ }^{41}$ and the government may be required to compensate the landowner (see Chapter 2 on Setbacks for a discussion on the facts of Lucas). ${ }^{42}$

According to the Lucas decision, regulators cannot simply circle problem areas on a map and proscribe all development. But Lucas has very limited application.

- First, Lucas applies when a regulation removes all economic value of the property. If there hasn't been a total reduction, the Penn Central balancing test (explained below) will be applied. Even if a statute severely restricts development of a coastal property, remaining uses like fishing and swimming may "constitute economically beneficial uses that still inhere in the property." 43

- $\quad$ Second, regulations that prohibit an activity that is considered a common law nuisance are not takings. Under Lucas, governments may still prohibit landowners from engaging in activities that have historically been considered nuisance. This raises a more difficult question about the ability of governments to label new types of activities as nuisances. For example, a legislature may declare an activity to be a nuisance (such as developing too near the shore or building seawalls), but its ability to make such a declaration "stick" in this context, absent a common law tradition of that nuisance in the state, may depend on the disposition of the courts. ${ }^{44}$

- Third, in dealing with Lucas concerns, government can still prohibit development on lands that are in the public trust (such as beach areas where the public has a preestablished easement for access) (see Chapter 2 on Rolling Setbacks and Easements).

\section{What about a total proscription on construction for a limited time?}

Regulation that wipes out economic value only for a limited time is not necessarily a Lucasstyle compensable taking. In Tahoe-Sierra Preservation Council, Inc. v. Tahoe Regional Planning Agency (2002), ${ }^{45}$ an agency imposed a moratorium on development in the Lake Tahoe basin until it could devise a plan for the area's future use and development. Affected landowners claimed that the moratorium was effectively a taking of their property, but the court disagreed. Such moratoria, which agencies may find valuable as they take stock of the coastal areas in their jurisdiction, are unlikely to be found to effect takings, if not too lengthy.

What if the developer is aware of the regulation, pre-purchase? 
Disclosure of the regulation does not eliminate the takings concern. Disclosure can provide other benefits (such as putting owners on notice and building awareness of the risks of coastal development) but will not guarantee immunity from a takings claim. ${ }^{46}$

\section{$\underline{\text { Reduction in Economic Value }}$}

Potential regulatory takings that reduce the economic value of a property but that do not deprive the owner of all economic benefit are evaluated under a balancing test derived from Penn Central Transportation Co. v. New York City (1978). ${ }^{47}$ The test comprises three factors: The economic impact of the regulation on the landowners; the extent to which the regulation interferes with legitimate investment-backed expectations; and the character of the government action. ${ }^{48}$

To bolster its case by providing value, government can confer transferable development rights (TDRs). TDRs are credits essentially created by the government that allow an owner to exercise his right to build, elsewhere. As Penn Central illustrated, TDRs have economic value, so conferring them helps blunt regulatory takings claims by retaining economic value for the owner. $^{49}$ (See Chapter 5 on Acquisition for discussion of TDR).

\section{Cautionary Principle}

Because of the absence of bright lines in the doctrine, legislators working towards managed retreat must recognize the general contours of the doctrine and proceed cautiously, basing their regulations on rigorous scientific work, while being mindful of the charged feelings that attend these issues. A legislator's political instincts are relevant here, for this process is greatly influenced by collective notions of fairness.

\section{FURTHER READING}

J. Peter Bryne, Rising Seas and Common Law Baselines: A Comment on Regulatory Takings Discourse Concerning Climate Change, 11 Vermont Journal of EnVIRONMENTAL LaW 625 (2009).

Meg Caldwell \& Craig Holt Segall, No Day at the Beach: Sea Level Rise, Ecosystem Loss, and Public Access along the California Coast, 34 Ecology LaW QuARTERly 533 (2007).

David L. Callies and J. David Breemer, Selected Legal and Policy Trends in Takings Law: Background Principles, Custom and Public Trust Exceptions and the (MIS) use of InvestmentBacked Expectations, 36 VALPARAISO UNIVERSITY LAW REVIEW 339 (2001) 339.

Dennis J. Hwang, Shoreline setback regulations and the takings analysis, 13 UNIVERSITY OF HAWAII LAW REVIEW 1 (1991). 
Hyo (Charlene) Kim and Caroline A. Karp, When Retreat is the Better Part of Valor: A Legal Analysis of Strategies to Motivate Retreat from the Shore, 5 SEA GRANT LAW AND Policy Journal 169 (2012).

Jon A. Kusler, No Adverse Impact: Floodplain Management and the Courts, AssOcIATION OF STATE FLOODPLAIN MANAGERS (2004), http://www.floods.org/NoAdverselmpact/NAI AND THE COURTS.pdf

James Titus, Rising Seas, Coastal Erosion, and the Takings Clause: how to Save Wetlands and Beaches Without Hurting Property Owners, 57 MARYLAND LAW REVIEW 1279-1399 (1998). 


\section{REFERENCES}

17 For an overview of how FEMA establishes SFHAs, see FEMA, Flood Zones, June 24, 2013, http://www.fema.gov/national-flood-insurance-program-2/flood-zones (last visited Aug. 7, 2013).

${ }^{18}$ See, FEMA, Floodplain Management: What must a community do to join the NFIP?, Jan. 8, 2013, http://www.fema.gov/floodplain-management (last visited Aug. 7, 2013); FEMA, Joining the National Flood Insurance Program, June 18, 2008, available at http://www.fema.gov/medialibrary/assets/documents/13610?id=3310.

${ }^{19}$ See, e.g., John Egan, Hurricane-battered States Lead in Payouts From National Flood Insurance Program, INSURANCEQUOTES.COM, June 9, 2011, http://www.insurancequotes.com/home/flood-insurance-payouts; Eli Lehrer, Reforming the National Flood Insurance Program after 35 Years of Failure, Competitive Enterprise Institute No. 2, at 7-9 (2008); Edward Wyatt and Mary Williams Walsh, For Flood Victims, Another Blow Is Possible, NEW YORK TIMES, Oct. 30, $2012 \quad$ http://www.nytimes.com/2012/10/31/business/for-flood-victims-another-blow-ispossible.html? $r=1 \&$ (last visited Aug. 7, 2013).

${ }^{20}$ Jo Ann Howard, NFIP Financial Stability: Time to Consider Alternatives to Current Model of Funding NFIP CAT Claims, 73-76 in BACKGROUND ReAdING FOR THE GILBERT F. White NATIONAL FLOOd POLICY FORUM 2007 ASSEMBLY: FLOOdPLAIN MANAGEMENT 2050 (Assembly of the GFW National Flood Policy Forum, 2007), available at http://www.asfpmfoundation.org/forum/2007 GFW Forum Background Reading.pdf\#page=89

${ }^{21}$ See Rawle O. King, National Flood Insurance Program: Background, Challenges, and Financial Status, CONGRESSIONAL RESEARCH SERVICE, June 12, 2012, available at http://digital.library.unt.edu/ark:/67531/metadc93819/m1/1/high res d/R40650 2012 Jun 12.pdf.

${ }^{22}$ FEMA, Answers to Questions about the National Flood Insurance Program, n.p., Mar. 2011,available at http://www.fema.gov/library/viewRecord.do?id=1404.

${ }^{23}$ The Biggert-Water Flood Insurance Reform Act of 2012, Pub. L. No: 112-141. §§ 100215(d), 100216 (b) (H.R. 4348, 112th Cong., 2012), available at http://www.gpo.gov/fdsys/pkg/BILLS---112hr4348enr/pdf/BILLS--112hr4348enr.pdf.

${ }^{24}$ The Geneva Association, The Geneva Reports Risk And Insurance Research (Meghan Orie and Walter Stahel, eds., 2013), at 31, available at https://www.genevaassociation.org/media/607750/ga-2013-geneva report7.pdf\#page=31.

25 FEMA, Biggert-Waters Flood Insurance Reform Act of 2012 Timeline, Apr. 2013, available at http://www.fema.gov/library/viewRecord.do?id=7275.

${ }^{26}$ FEMA, Questions about the Biggert-Waters Flood Insurance Reform Act of 2012, Apr. 2013, available at http://www.fema.gov/library/viewRecord.do?id=7266.

${ }^{27}$ FEMA, Historic Structures and the Biggert-Waters Flood Insurance Reform Act of 2012: Fact Sheet, http://www.fema.gov/media-library-

data/e279bc445f601f57c0bd81a3f401b8a6/Historic Structures Fact Sheet 2013 2.pdf (last visited Oct. 10, 2013).

${ }^{28}$ Table in FEMA, The NFIP's Specific Rate Guidelines: Biggert Waters Flood Insurance Reform Act of 2012, p2, http://www.fema.gov/media-library-data/20130726-1920-25045-7258/fact sheet specific rate guidelines.pdf (last visited Oct. 10, 2013).

${ }^{29} / d$. at 3.

${ }^{30}$ FEMA, Questions, supra note 26. 
${ }^{31}$ See GeneVa Association, supra note 24.

${ }^{32}$ See Eli Lehrer, Strange Bedfellows: Smartersafer.org and the Biggert-Waters Reform Act of 2012, 23 DUKE ENVIRONMENTAL LAW AND POLICY FORUM 351 (2013).

${ }^{33}$ For a discussion on reinsurance and federal natural disasters, see CONGRESSIONAL BUDGET OfFICE, A CBO STUDY: FEDERAL ReINSURANCE FOR DisAsters (2002).

${ }^{34}$ Dolan v. City of Tigard, 512 U.S. 374, 391 (1994).

${ }^{35}$ Nollan v. California Coastal Commission, 483 U.S. 825 (1987).

${ }^{36}$ Koontz v. St. John's River Management District, No. 11-1447 U.S. (2013), citing Village of Euclid v. Ambler Realty Co., 272 U.S. 365 (1926).

${ }^{37}$ See J. Peter Byrne \& Jessica Grannis, Coastal Retreat Measures, in ThE LAW Of AdAPTATION TO CLIMATE ChANGE (Michael Gerrard and Katrina Kuh, eds., 2012), 278.

${ }^{38}$ Koontz v. St. John's River Management District, No. 11-1447 U.S. (2013).

${ }^{39}$ Id. at 2589.

${ }^{40}$ Id. citing Regan v. Taxation With Representation of Wash., 461 U.S. 540, 545 (1983).

${ }^{41}$ Lucas v. South Carolina Coastal Council, 505 U.S. 1003 (1992).

${ }^{42}$ Byrne, supra note 37.

${ }^{43}$ See Wyler v Board of Environmental Protection, 747 A.2d 192 (Me. 2000) (holding that beachfront property that could still be used for recreational purposes was not devoid of economic value); see also Hyo (Charlene) Kim and Caroline A. Karp, When Retreat is the Better Part of Valor: A Legal Analysis of Strategies to Motivate Retreat from the Shore, 5 Sea Grant Law and Policy Journal 169 (2012).

${ }^{44}$ See Lucas v. South Carolina Coastal Council, 505 U.S. 1003 (1992) (stating that regulation removing all economic value could have been saved if it had been prohibited by state common law nuisance claim).

${ }^{45}$ Tahoe-Sierra Preservation Council, Inc. v. Tahoe Regional Planning Agency, 535 U.S. 302 (2002).

${ }^{46}$ See Palazzo v. Rhode Island, 533 U.S. 606 (2001).

${ }^{47}$ Penn Central Transportation Co. v. New York City, 438 U.S. 104 (1978).

${ }^{48} / d$.

${ }^{49}$ See Kent Messer, Transferable Development Rights Programs: An Economic Framework for Success, 3 JouRNAL OF CONSERVATION PLANNING 47, 52 (2000). 


\section{CHAPTER 1}

\section{Coastal Management Planning}

Managed retreat from vulnerable coastlines is only one element of coastal management, and it should not be pursued in isolation but rather should be incorporated as part of a cohesive, comprehensive coastal management plan. Long-term retreat from vulnerable shoreline begins with a plan that limits development, promotes environmental conservation, recognizes the importance of natural cycles of beach erosion and nourishment, and encourages public access to the shore.

Coastal planning occurs at the federal, state, and local levels and these plans should be coordinated to ensure that they pursue the same goals. The discussion that follows outlines the general framework of federal, state, and local planning with illustrative examples. In order to promote managed retreat, such plans can and should include explicit language that makes it clear that retreating from the coast in order to prevent repetitive losses of life and property is a priority for coastal management. No isolated effort towards managed retreat will be entirely successful. Rather, the principle of retreat needs to be emphasized throughout the coastal management program.

\section{Federal Coastal Planning}

In addition to the Coastal Zone Management Act (discussed below), the federal government has a taken a role in coastal planning in specialized areas of the coast.

$\underline{\text { Rivers and Harbors Appropriation Act of } 1899^{50}}$

Congress enacted the Act to ensure free and open navigability of the nation's waterways. The Act prohibits any action to excavate, fill, or alter the course, condition, or capacity of any port, harbor, channel, or other areas within the reach of the Act without a permit. ${ }^{51}$ The building of any wharfs, piers, jetties, and other structures is prohibited without Congressional approval, and excavation or fill within navigable waters requires the approval of the Chief of Engineers. $^{52}$

In a 2009 decision, United States v. Milner, 583 F.3d 1174 (9th Cir. 2009), the Ninth Circuit ruled that four coastal property owners had violated the Act because they refused to remove coastal erosion structures. The structures were lawfully constructed on the homeowner's dry lands, inland of the mean high water mark, and were intended to protect private homes from erosion and storms. However, due to sea level rise and coastal erosion, the structures intersected the ocean and were found to be a trespass and violation of the Section 10 of the 
Rivers and Harbors Act. The property owners were therefore required to remove the structures. 53 The court noted, "While the Homeowners cannot be faulted for wanting to prevent their land from eroding away, we conclude that because both the upland and tideland owners have a vested right to gains from the ambulation of the boundary, the Homeowners cannot permanently fix the property boundary" between private and public lands. ${ }^{54}$ (See Chapter 4 on Prohibiting Armoring for more on preventing coastal protection structures and public ownership of the tidelands.)

\section{Coastal Barrier Resources Act (CBRA) of $1982^{55}$}

Prior to the CBRA, the federal government had subsidized and encouraged development on coastal barriers. This resulted not only in the loss of natural resources as these barriers were damaged but also in increased threat to human life and property and the expenditure of millions of tax dollars every year to combat the risks faced by property owners on these barriers. ${ }^{56}$ The CBRA therefore designated undeveloped coastal barriers as part of a protected system and made this system ineligible for most federal funding (including the National Flood Insurance Program). As a result, individuals who choose to develop and live on these hazardprone areas bear the economic burden. A 2002 study by the U.S. Fish and Wildlife Service estimated that between 1982 and 2010, CBRA saved \$1.3 Billion in federal taxpayer money. ${ }^{57}$

National Marines Sanctuary Act (NMSA) of $1972^{58}$

The NMSA protects areas of marine environment deemed to have national significance, including some coastal areas, by issuing regulations and implementing penalties for violations. The NMSA was last reauthorized in November 2000 and reauthorization is currently in process. $^{59}$ The NMSA does not have a direct impact on managed retreat but policymakers should be aware of any sanctuaries within their jurisdiction when creating state and local management plans.

\section{Coastal Zone Management ACt}

The primary role the federal government has taken in coastal management planning is through its promotion of state coastal planning under the Coastal Zone Management Act (CZMA) of $1972 .^{60}$ The CZMA is administered by the NOAA Office of Ocean and Coastal Resource Management (OCRM), and it aims to "preserve, protect, develop, and where possible, to restore or enhance the resources of the nation's coastal zone." ${ }^{61}$ One of the explicit goals of the CZMA $(\S 303)$ is to "minimize the loss of life and property in coastal hazard areas," a goal that can be achieved in the long-term through gradual retreat from vulnerable coastal areas. 
The CZMA established two national programs: the National Coastal Zone Management Program and the National Estuarine Research Reserve System. The Management Program is the primary focus for the purposes of this Handbook. The Program requires states to create and implement coastal management programs in order to qualify for federal funding grants. ${ }^{62}$ Grants are awarded to assist in the initial development of coastal management programs, ${ }^{63}$ administrative costs, ${ }^{64}$ coastal resource improvements, ${ }^{65}$ projects to protect coastal waters, ${ }^{66}$ and coastal zone enhancement. ${ }^{67}$ In Fiscal Year 2012, NOAA invested over $\$ 65$ million in federal funding and directly supported 675 jobs. ${ }^{68}$ Thirty-four of the 35 eligible coastal and Great Lakes states and territories participate in the CZMA Management Program. ${ }^{\ddagger}$

\section{Reverse Federalism}

The CZMA is unusual as a federal act in that it gives states greater power than the federal government. ${ }^{69}$ It contains what has been referred to as a "reverse supremacy clause." ${ }^{70}$ Section 1456(c) of the CZMA requires the federal government, "to the maximum extent practicable," to ensure that federal practices are consistent with approved state plans. A similar review requirement exists for private actions that require a federal license or permit, such as oil and gas exploration, development, and production. ${ }^{71}$ Congress has described the state CMP consistency review process as the "single greatest incentive for State participation in the coastal zone management program." ${ }^{\prime 72}$ In fact, the state compliance aspect of the CZMA is so important that when the Supreme Court limited the scope of the consistency doctrine, Congress amended the Act explicitly to overturn the Court decision and expand the power of States to control actions that affect their coasts. ${ }^{73}$

When a federal agency proposes an action that may affect the coastal zone, the agency must provide a written statement to the state explaining that the action is consistent with the state CMP. ${ }^{74}$ The state agency may object to the activity, and the two agencies may then either submit to the Secretary of Commerce for mediation ${ }^{75}$ or the state may bring suit in federal court. $^{76}$ In rare cases, the President may, upon written request from the Secretary of Commerce, exempt a federal program "if the President determines that the activity is in the paramount interest of the United States." ${ }^{177}$

The State CMP and the ability of the state to review and influence federal actions to be consistent with the CMP give the state a powerful tool for coastal management. This tool, however, depends in great deal on the quality of the state CMP and the ability of state agencies to enforce the consistency requirement.

\footnotetext{
${ }^{\ddagger}$ Alaska withdrew from the program in 2011 (discussed more below) and Illinois joined in 2012.
} 


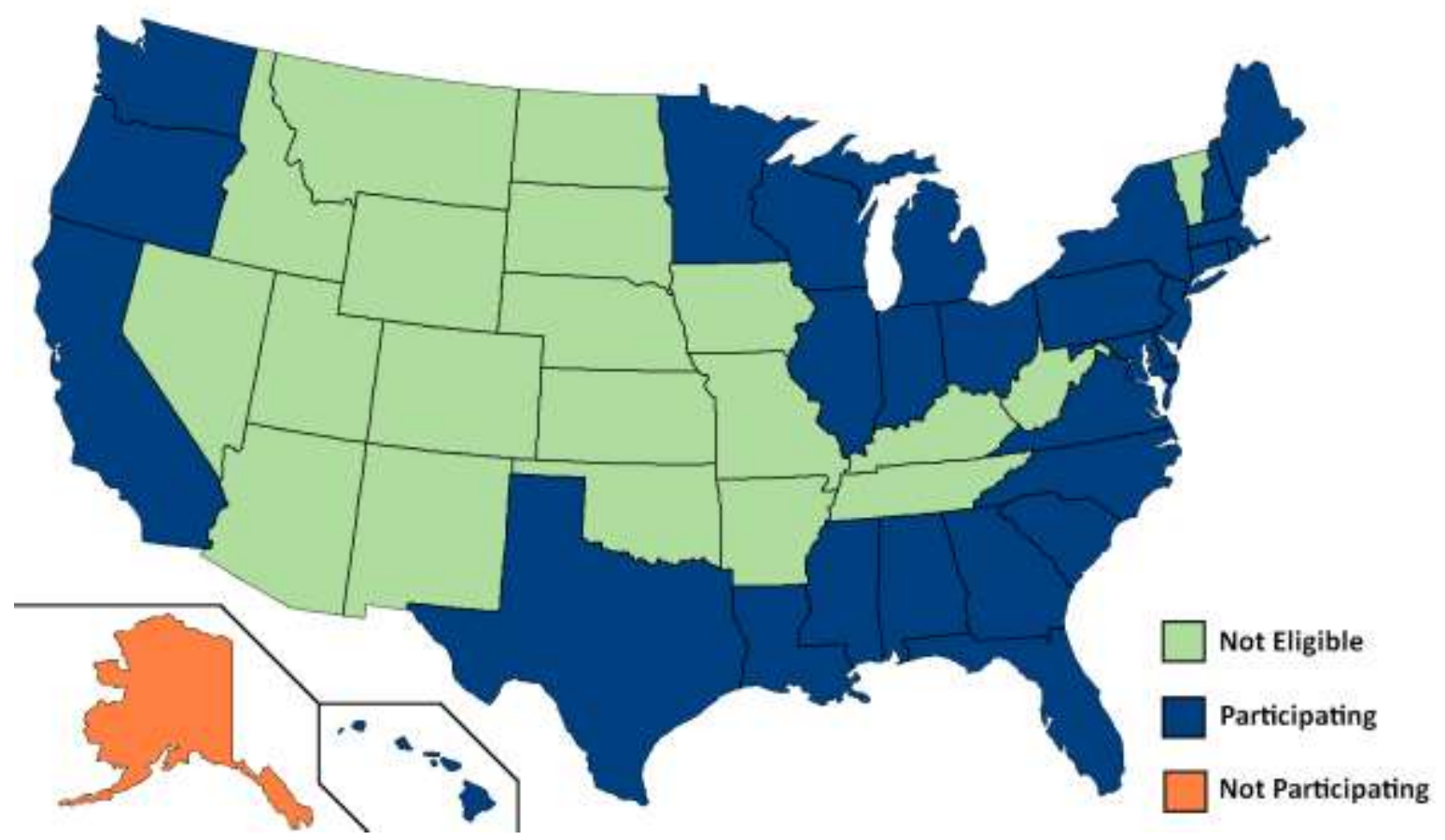

States participating in the CZMA Management Program. Data from NOAA.

\section{Future of the CZMA}

The CZMA has been in place for 41 years, and NOAA has begun to look at how the CZMA can continue to inform coastal policy in the future. In 2006 and 2007, OCRM partnered with the Coastal States Organization to conduct a series of meetings and workshops with coastal managers, stakeholders, and federal agencies with the goal of making recommendations for administration and legislative changes for an improved CZMA. ${ }^{78}$ Although these recommendations have not yet been implemented, state level policy makers should be aware of these activities and should be prepared to engage if they want to shape the future of federal coastal planning.

\section{State Coastal Management Programs}

State Coastal Management Programs (CMPs) translate the overarching principles of the CZMA into actionable goals and regulations. They represent an important opportunity to coordinate federal, state, and local actions by setting out clear goals and providing direction to local governments. The following examples illustrate the types of planning goals that can be accomplished. 


\section{Texas Coastal Management Program}

The Texas CMP was authorized under the Coastal Coordination Act of $1991^{79}$ and approved by NOAA in 1996. The program is administered by the Texas Land Commissioner in the General Land Office (GLO), who is advised by the Coastal Coordination Advisory Committee. ${ }^{80}$ The Texas CMP provides coastal enhancement grants to state and local entities to increase and improve public access to beaches; to protect and restore critical areas such as wetlands; to improve water quality, natural hazards response, and information and data availability; and to conduct public education and outreach activities. ${ }^{81}$ Annually, the GLO receives $\$ 2.5$ million in federal funds under the coastal resource improvement program (CZMA §306/§306A), program enhancement $(\S 309)$, and the state's coastal nonpoint source pollution (NPS) control program $(\S 310) .{ }^{82}$

\section{Federal Review}

As discussed above, due to a "reverse supremacy" clause in the CZMA, federal actions within a state that has a CMP is required to comply with the CMP and can be reviewed by state authorities. In Texas, the GLO conducts a Federal Consistency Review of all federal construction projects, permitting or licensing actions,

\section{Texas' Coastal Zone}

Texas' coastal zone is the general area seaward of the Texas coastal facility designation line, which roughly follows roads that are parallel to coastal waters and wetlands within one mile of tidal rivers. The boundary encompasses portions or all of 18 coastal counties. Texas has 3,359 miles of coastline and a coastal population of $6,121,490$ as of 2010. and federal financial assistance projects in the coastal zone. In fiscal year 2012, the GLO reviewed 241 federal license or permitting actions and 138 financial assistance projects. ${ }^{83}$ The public is also invited to make comments on coastal projects under review, ensuring that local communities have a voice in the process.

\section{$\underline{\text { State Permitting }}$}

Overlapping jurisdiction between federal and state agencies can further complicate an already complicated permitting process for common projects. In order to reduce redundancies and streamline this process, Texas implemented a Joint Permit Application Form (JPAF) and established a Permit Service Center.

JPAFs simplify the permitting process by providing a consolidated permit application to be simultaneously distributed to multiple authorizing agencies. The Permit Service Center provides technical advice to individuals, small businesses, and local governments on the permit application process. This is a service to the individuals, who may not have the technical knowledge or expertise to complete the applications properly. It also benefits agencies by troubleshooting applications before they are submitted. This ensures efficiency and reduces processing time. During fiscal year 2012, the Public Service Center assisted with 211 applications, including 151 JPAFs. The average processing time was just 3.5 days. ${ }^{84}$ Reporting Requirement 
Section 33.204(f) of the Texas Coastal Coordination Act requires the GLO and other networked agencies to prepare an annual report on the effectiveness of the CMP. This includes an evaluation of set performance measures and quantifiable actions. ${ }^{85}$ This reporting requirement serves an important role in ensuring that the coastal plan is effectively executed.

Storm surge damage from Hurricane Ike in Galveston, TX (2008). There were once 4 piered structures along this section of the seawall. Photo: NOAA Flower Garden National Marine Sanctuary.

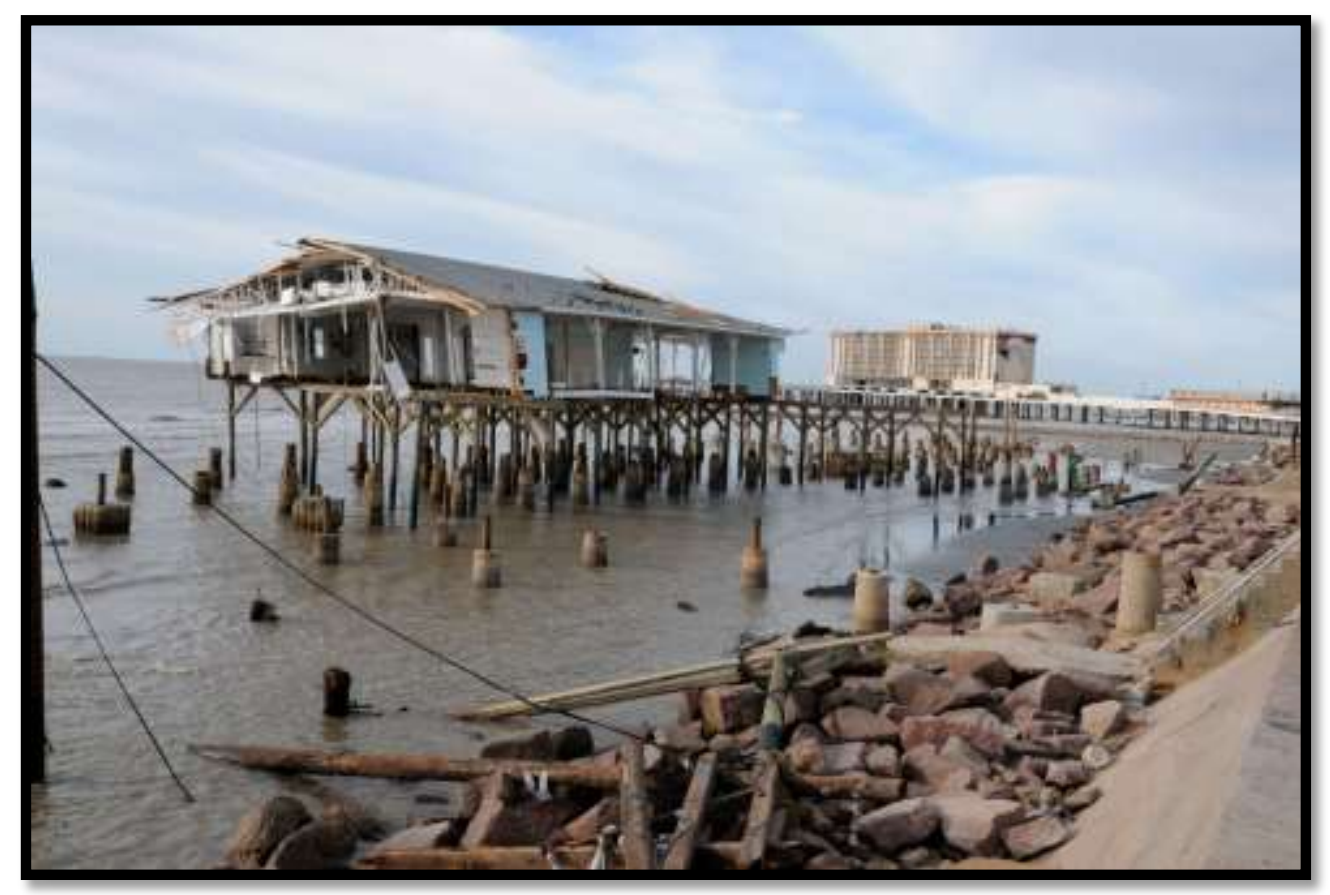

\section{A Note on Alaska}

Alaska has more coastline than the rest of the 49 states combined ${ }^{86}$ - some 6,640 miles of general coastline and 33,904 miles of tidal shoreline ${ }^{87}$ - yet it is the only coastal state currently not participating in the federal Coastal Zone Management Program. Alaska originally joined the program in 1979, but the implementing state legislation contained a sunset clause, and the program lapsed in 2011 when the Alaska state legislature declined to extend it. ${ }^{88}$

In 2012, the Alaska Sea Party, a grassroots organization created to promote coastal management, tried to resurrect the program. Their petition eventually became a ballot initiative, but it was defeated; nearly two-thirds of the votes were against Ballot Measure 2. Only an estimated $25 \%$ of registered voters turned up to vote. ${ }^{89}$ The ballot faced strong opposition from a "Vote No" organization that was bankrolled with $\$ 1.8$ million funded largely by oil and gas industries. ${ }^{90}$

Opponents of the Alaska Coastal Management Program argue that the state program limits resource development by adding bureaucratic red tape. Supporters argue that the state needs to maintain a balance between resource development and environmental conservation in order 
to preserve quality of life for its citizens and that a state plan gives local communities greater say in coastal development. ${ }^{91}$

Without a CMP, Alaska lost approximately \$2.5 million in federal funds annually. Even more importantly, Alaska lost its ability to use the CZMA consistency requirement to influence federal agency activities and federal license or permit activities in the Alaska coast. ${ }^{92}$ As a result, the Alaskan coastline is primarily managed by the federal government rather than the state itself.

Some commentators have suggested that this may be detrimental to state efforts to promote adaptation and retreat, as the federal government may have greater interest in promoting development of off-shore oil and gas reserves than in protecting local coastal communities. ${ }^{93}$

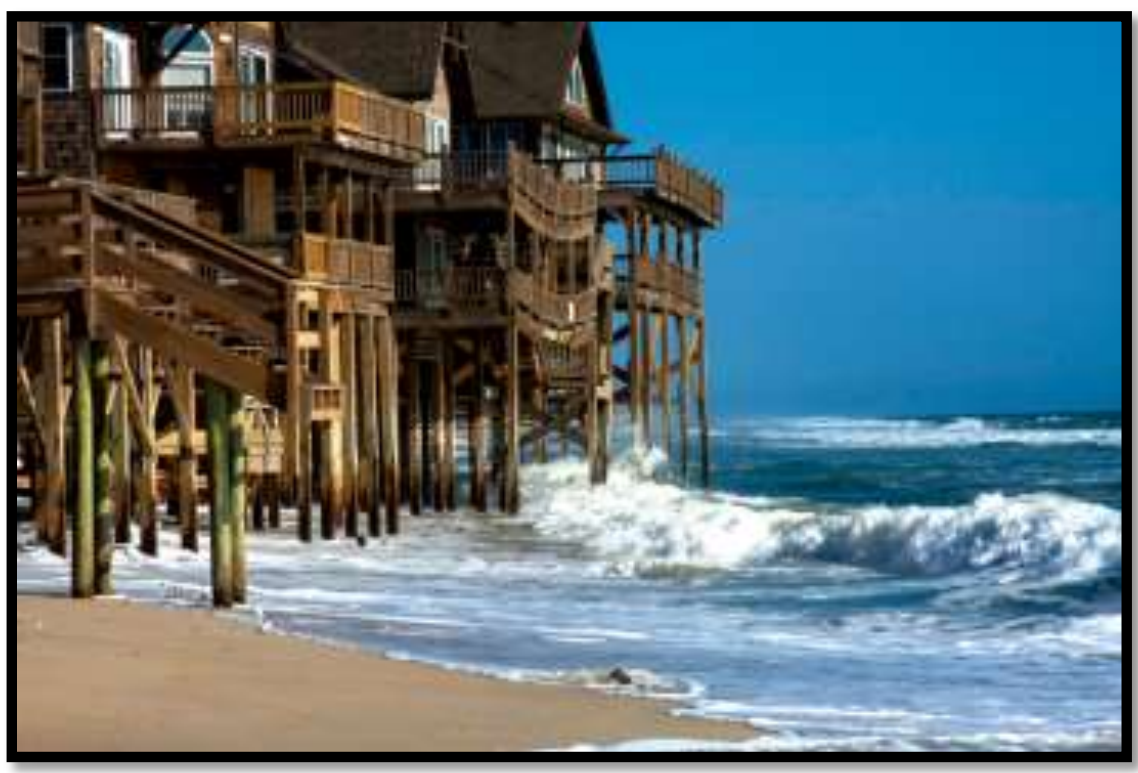

Rodanthe, North Carolina, September 2, 2011. These raised homes once had yards of beach between them and the sea, until Hurricane Irene hit the coast. Photo: FEMA / Tim Burkit.

\section{Local Plans and State Mandated Planning}

Coastal management planning requires extensive local coordination, and local planning and implementation therefore play a critical role in achieving broader state-wide and regional hazard mitigation goals. ${ }^{94}$ Increased and improved local planning has been consistently requested by academics, ${ }^{95}$ environmental organizations, ${ }^{96}$ developers, ${ }^{97}$ and the American Planning Association. ${ }^{98}$ Local plans provide the best opportunity for public participation and for community tailoring. However, local communities sometimes lack the commitment and resources to develop the detailed, comprehensive plans necessary for hazard mitigation. ${ }^{99}$ This lack of technical knowledge is particularly pronounced with respect to coastal hazards as climate change adds a novel layer of complexity. ${ }^{100}$ 


\section{State-Mandated Planning}

State legislation that mandates local planning can assist with these problems. Specifically, state-mandates can:

- Provide explicit authorization to local governments to address coastal hazards and coastal development; ${ }^{\S}$

- Secure funding for the creation and administration of local plans (through the CZMA or state initiatives);

- Identify specific goals for local plans and set priorities for communities; and

- Establish minimum requirements for plans and implementation measures.

In the 1990s, a research team led by Raymond Burby of the University of North Carolina and Peter May of the University of Washington conducted a multi-state assessment that showed state mandates improved the quality of local plans. ${ }^{101}$ The team compared local plans in counties that had no state mandate (Texas, Washington, and inland North Carolina) ${ }^{* *}$ with those in states that did (California, Florida, and coastal North Carolina). They concluded that the presence of a state mandate improved local plans and that North Carolina's coastal state mandate was the most effective of the three that were studied. ${ }^{102}$

Planning mandates can provide structure and facilitation for local plans. ${ }^{103}$ Facilitating features of state mandates are those that guide state agencies to assist local governments. This can be through provision of funding, scientific information, or technical expertise. ${ }^{104}$

\section{California State Planning Act of 1937 \\ (Cal. Gov. Code, Chapter 3, § 65100 et seq.)}

California was the first state in the United States to mandate local planning. A 1971 amendment required local governments to incorporate plans to reduce risk from earthquakes, landslides, and floods.

Florida State Comprehensive Planning Act of 1972 (Fla. Stat. Ann. §§186.001 et seq. \& §§186.801 et seq.)

Florida's 1972 law required local governments to adopt comprehensive plans but lacked enforceable standards. It was amended in 1985 to strengthen the requirements and to address hurricane response and capital improvement in hazard areas.

North Carolina Coastal Area Management Act of 1974 (N.C. Gen. Stat. §§113A-106 et seq. (1993))

North Carolina requires planning in coastal counties and municipalities. It originally focused on protecting coastal resources but was expanded to include a broader range of integrated development management goals.

\footnotetext{
$\S$ The 1994 South Carolina Local Government Comprehensive Planning Enabling Act (SOUTH CAROLINA CODE ANN. § 629-310 et seq.), for example, consolidated existing authorizations for local land use planning and regulation into a single location and authorized new zoning powers such as cluster development, performance zoning, and floating zones. See Douglas Kendall, Preserving South Carolina's Beaches: The Role of Local Planning in Managing Growth in Coastal South Carolina, 9 South CARolina EnVIRONMENTAL LAW JouRnal 61, 66 (2000).

** Texas and Washington did not have planning mandates during the time period of the study (pre-1990). Washington has since adopted state-mandated local planning. RCW 36.70 and 36.70A.
} 
Structural features are those in which the state guides the content and shape of local plans. The most obvious structural components are the goals for coastal planning. Such goals should be clear, specific, and prioritized in order to have the greatest impact on local planning. Clear and specific goals are those that do not leave too much room for interpretation by local planners. ${ }^{105}$ For example, 'reduce public property loss from hurricanes' is a clearer goal than 'mitigate coastal hazards' and provides greater direction to local governments. The fewer state level agencies involved in implementing the mandate, the less frequently goals will have to be re-interpreted and the more likely goals are to be translated into concrete actions at a local level. ${ }^{106}$

Prioritization of goals is necessary because local governments are attempting to implement numerous policies with limited resources (personnel and financial) and need to know where to invest. ${ }^{107}$ For example, state mandates can identify whether economic growth, coastal resource preservation, or public safety is the highest priority to be pursued by local planners. According to the multi-state assessment:

[C]lear state mandate goals appear to be important in explaining the high quality of plans in the North Carolina coastal area. North Carolina's mandate specifically suggests that plans should mitigate future disasters by limiting public infrastructure in hazard zones, decreasing development densities, and incorporating mitigation during reconstruction. In contrast, California's mandate goal simply indicates that communities should adopt plans that protect citizen safety and reduce property losses. The vague nature of the California mandate gives local governments too much latitude in addressing these issues. ${ }^{108}$

Structure also refers to the extent to which a state-mandate is coercive or permissive. A coercive state mandate is one that ties specific punishments to non-compliance, such as revocation or non-allocation of funding or state pre-emption. The more coercive a state mandate is, generally the more likely local communities are to comply. ${ }^{109}$ State mandates can have strong coercive language but still be ineffective if implementing state agencies are reluctant to enforce the mandate. The multi-state assessment found that Florida had the most coercive language in its mandate but that North Carolina agencies were more likely to use their enforcement power. ${ }^{110}$

In order to be as effective as possible in promoting local planning, state legislation that mandates local planning should:

- Identify clear, specific goals;

- Prioritize goals and explain how these priorities fit with other state-wide initiatives;

- Include clear guidelines and minimum standards;

- Simplify oversight mechanisms and reduce the number of interpreting and enforcing state agencies;

- Provide technical assistance where necessary; 
- Provide financial resources when feasible; and

- Establish punitive measures for non-compliance and encourage enforcement.

\section{$\underline{\text { Implementation and Buy-In Challenges }}$}

Even with all of these factors, the success of local planning (whether state mandated or voluntary) will depend in large part on the implementation of the plan. The presence of a plan has been shown to influence the success of local policies, ${ }^{111}$ but it is not sufficient on its own. In their multi-state assessment, Burby and May concluded that none of the localities, even those with state-mandated planning did "a very good job of addressing natural hazards" and on average the local plans received only a 1.35 out of a 5 point scale for natural hazards. ${ }^{112}$

Local commitment to the end goals and to the planning process was one of the most important factors. ${ }^{113}$ Political pressures were, of course, important in influencing the commitment of local officials, and staff capacity to undertake the plan was also a limiting factor. $^{114}$

Public participation in the planning process is important both as its own end and as a means to facilitate implementation. ${ }^{115}$ Community involvement in local planning and governance decisions is always important to promote participatory democracy, to achieve fair results, and to give disadvantaged communities a voice. ${ }^{116}$ Community participation also raises awareness of the risks, ${ }^{117}$ which can be particularly important with respect to climate change, where the threats are going to change over time and are not the same as those experienced in the past. Participation gives individuals a sense of ownership and control over the decision-making process, and it can be useful for creating consensus, which increases the chances of the plan being implemented in a meaningful way. ${ }^{118}$

The North Carolina Coastal Area Management Act and Maine Shoreland Zoning Act present two different approaches to state mandated planning.

\section{North Carolina Coastal Area Management Act}

The North Carolina Coastal Area Management Act of 1974 (CAMA) ${ }^{119}$ was designed to protect the state's disappearing coastal resources by balancing the goals of economic growth and resource preservation. The Act includes four parts: (1) State-mandated local planning in the 20 coastal counties (including 5 year updates); (2) State aid grants to local communities; (3) Coastal area land acquisition, and (4) Regulatory permitting in Areas of Environmental Concern (AEC). CAMA gives the Coastal Resources Commission (CRC) authority to develop policies and guidelines for development activities in the AECs. ${ }^{120}$

In 1994, Governor Hunt established the North Carolina Coastal Futures Committee to review the success of CAMA and recommend improvements. The Committee published 203 
recommendations in 1994, including several recommendations to improve local land use planning. ${ }^{121}$ These recommendations include, among others:

- Improve technical assistance for local planning;

- Improve financial support for local planning;

- Increase public participation in land use planning;

- Educate local officials and increase their role in land use planning;

- Require implementation provisions in plans;

- Perform periodic performance audits of plan implementation;

- Tie local government eligibility for growth-related state and federal grants to the adoption of a land use plan and implementation program; and

- Identify key regional issues and encourage regional cooperation. ${ }^{122}$

Many of these recommendations have yet to be fully implemented. For example, the report recommended tying eligibility for growth-related funds to the adoption of a land use plan. Rather than make this a strict requirement, the North Carolina Department of Environment and Natural Resources offers bonus points to local governments with a plan and additional bonus points if the plan has an implementation strategy. ${ }^{123}$

In 1995, "new planning guidelines were approved that addressed many of the CFC's concerns," ${ }^{124}$ but these new guidelines proved controversial. In 1998, CAMA encountered substantial resistance from local communities when the CRC considered expanding the area in which CAMA development controls apply. ${ }^{125}$ In 1998, the CRC therefore adopted a two year moratorium on local planning and appointed a Land Use Planning Review Team to review the guidelines and administrative rules during the moratorium. ${ }^{126}$ The Team's final report, released in August 1999, recommended (among other things) that local land use planning requirements be extended throughout the river basins (rather than being confined to the coasts), that the state provide technical and financial assistance to local governments for updating land use plans, and that land use plans be tied to state funding for infrastructure improvement. ${ }^{127}$

One possible reason for recommending increased technical support to local governments would be to reduce their reliance on private consulting firms. In a survey of 40 local coastal land use plans in North Carolina, 30 were prepared entirely or in part by a private consulting firm, and at least 15 of those were prepared by the same firm. ${ }^{128}$ The use of consultants may overcome a lack of technical knowledge at the local government level, but it also reduces government engagement with the process, which can reduce officials' commitment to implementing the plan. ${ }^{129}$

North Carolina's state-mandated planning process has been described as one of the best in the country, but it still has significant progress to be made in local capacity building and implementation. 


\section{A Note on House Bill 819 - Sea Level Rise}

In March 2010, the North Carolina Coastal Resource Commission Science Panel on Coastal Hazards published a report on the predicted rates of sea level rise it expected North Carolina to experience by $2100 .^{130}$ The report summarized the conclusions of multiple studies, discussed upper and lower limits, and concluded that "The most likely scenario for 2100 AD is a rise of 0.4 meters to 1.4 meters (15 inches to 55 inches) above present". ${ }^{131}$ It went on, "Given the range of possible rise scenarios and their associated levels of plausibility, the Science panel recommends that a rise of 1 meter (39 inches) be adopted as the amount of anticipated rise by 2100 , for policy development and planning purposes." ${ }^{132}$

In 2011, State Senator David Rouzer (R) added language to the existing House Bill 819 that would have limited the CRC to using linear, historical data of sea level rise. By mid-2012, the bill stipulated:

Historic rates of sea-level rise may be extrapolated to estimate future rates of rise but shall not include scenarios of accelerated rates of sea-level rise unless such rates are from statistically significant, peer-reviewed data and are consistent with historic trends. ${ }^{133}$

This language was extremely controversial, as non-linear, accelerated sea level rise scenarios are not uncommon in the scientific literature and represent some of the most recent scientific advancements in the field. ${ }^{134}$ The graph below illustrates a range of global mean sea level rise scenarios, as calculated by NOAA for the National Climate Assessment. ${ }^{135}$ The various scenarios depend on predicted levels of future global greenhouse gas emissions and melting rates of glaciers. A linear projection of the historic baseline sea level rise would look most like the lowest case scenario, which could under-predict sea level rise by as much as $1.8 \mathrm{~m}$ (the difference between lowest and highest scenarios).

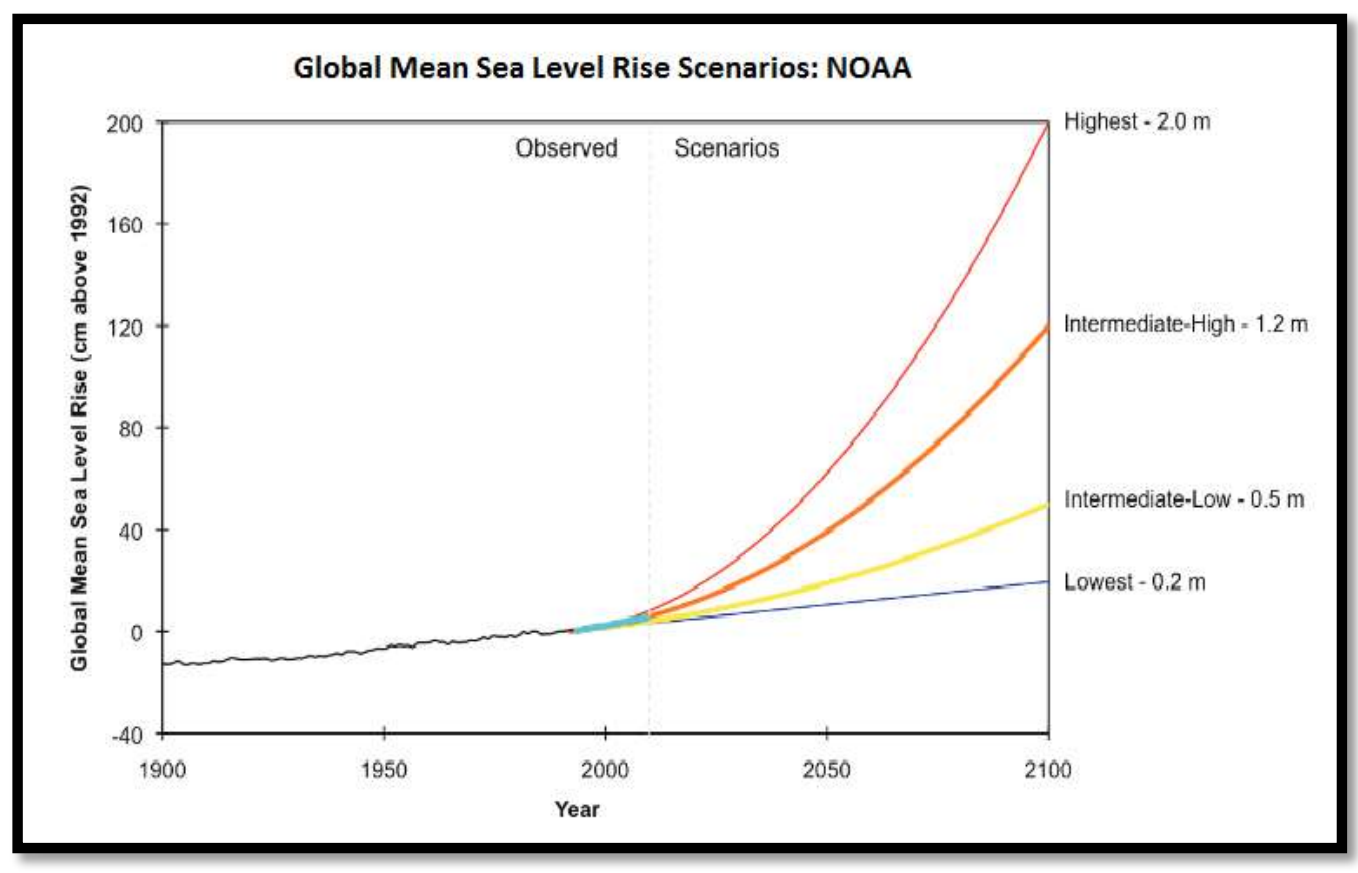


The language in House Bill 819 was eventually softened, and, in the end, the legislation does not limit North Carolina to a linear sea level rise projection. Rather, the law prevents the state from defining a rate of sea level rise for regulatory purposes before July 1, 2016 and, during the intervening years, directs the Science Panel to issue an updated report that includes a "summary of peer-reviewed scientific literature that address the full range of global, regional and North Carolina-specific sea-level change data and hypotheses, including sea-level fall, no movement in sea level, deceleration of sea-level rise, and acceleration of sea-level rise." ${ }^{136}$

The legislation became law when it passed both houses and Governor Beverly Perdue decided to neither sign nor veto. In a statement, Governor Perdue said the bill would become law "because it allows local governments to use their own scientific studies to define rates of sea level change." ${ }^{137}$ of course, given their resource constraints and technical limitations, it is unlikely that many local governments (if any) will establish their own sea level rise estimates. As a result, the four year delay on establishing a sea level rise estimate effectively means that North

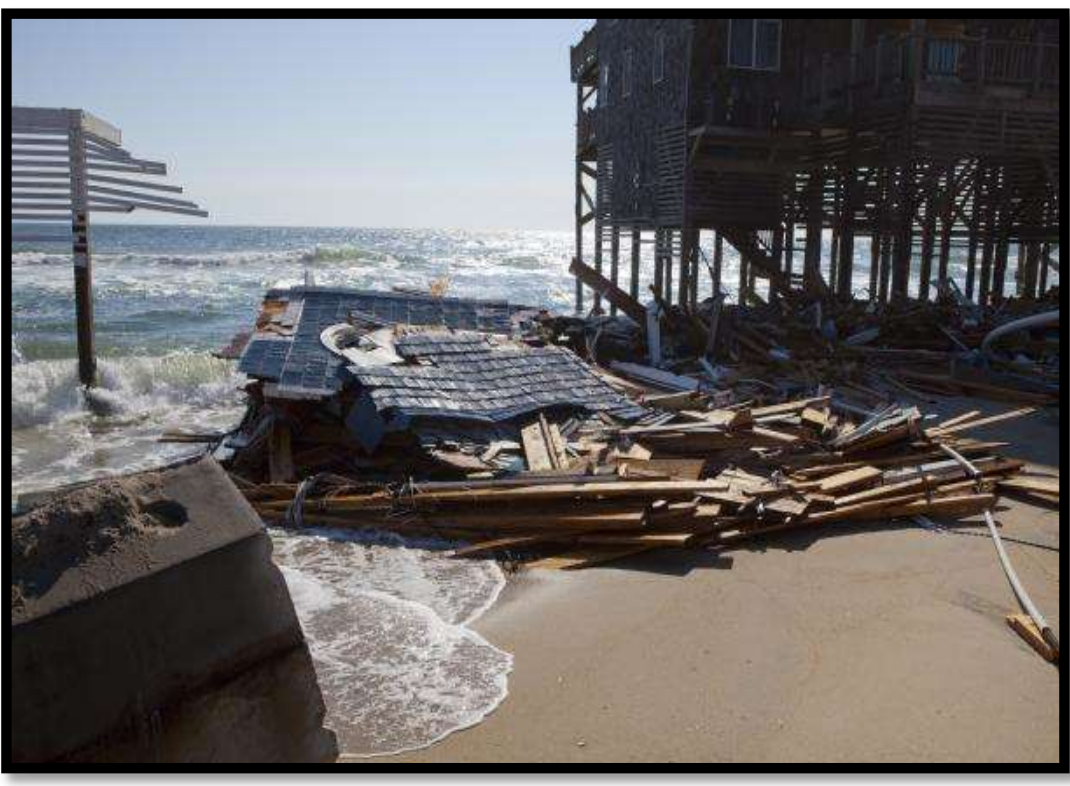

Rodanthe, North Carolina, Sep. 3, 2011. Hurricane Irene destroyed homes and eroded beaches to the point that the waves now reach under this elevated house.

Carolina is delaying effective regulation for four years, during which time coastal development can expand and limit the state's options when it eventually does turn its attention to sea level rise response.

State Representative Deborah Ross described the situation this way: "By putting our heads in the sand literally, we are not helping property owners. We are hurting them. We are not giving them information they might need to protect their property. Ignorance is not bliss. It's dangerous." 138

\section{Maine Shoreland Zoning Act}

The clearest example of state legislation providing direct guidance and minimum standards for local planning is the Maine Mandatory Shoreland Zoning Act (MSZA). ${ }^{139}$ The Act requires all municipalities to adopt, administer, and enforce local ordinances to regulate land use activities within 250 feet of great ponds, rivers, freshwater and coastal wetlands, and all tidal waters and within 75 feet of streams. One of the specific purposes of the Act is to "protect buildings and lands from flooding and accelerated erosion." 140 
The Act authorizes the Maine Department of Environmental Protection (MDEP) to establish minimum guidelines for local ordinances. Municipalities are not required to adopt the guidelines exactly - in fact, they are encouraged to tailor the guidelines to their specific community. However, the local ordinance must be at least as stringent as the DEP guidelines. ${ }^{141}$ The "Guidelines" are actually a model ordinance that enables localities to easily adopt, modify, or expand on the recommended provisions. If local governments fail to enact a municipal ordinance that is at least as strict as the guidelines, the Act not only authorizes but requires MDEP to adopt a suitable zoning ordinance. ${ }^{142}$ At present, 54 coastal communities in Maine have state imposed ordinances under this Act. ${ }^{143}$

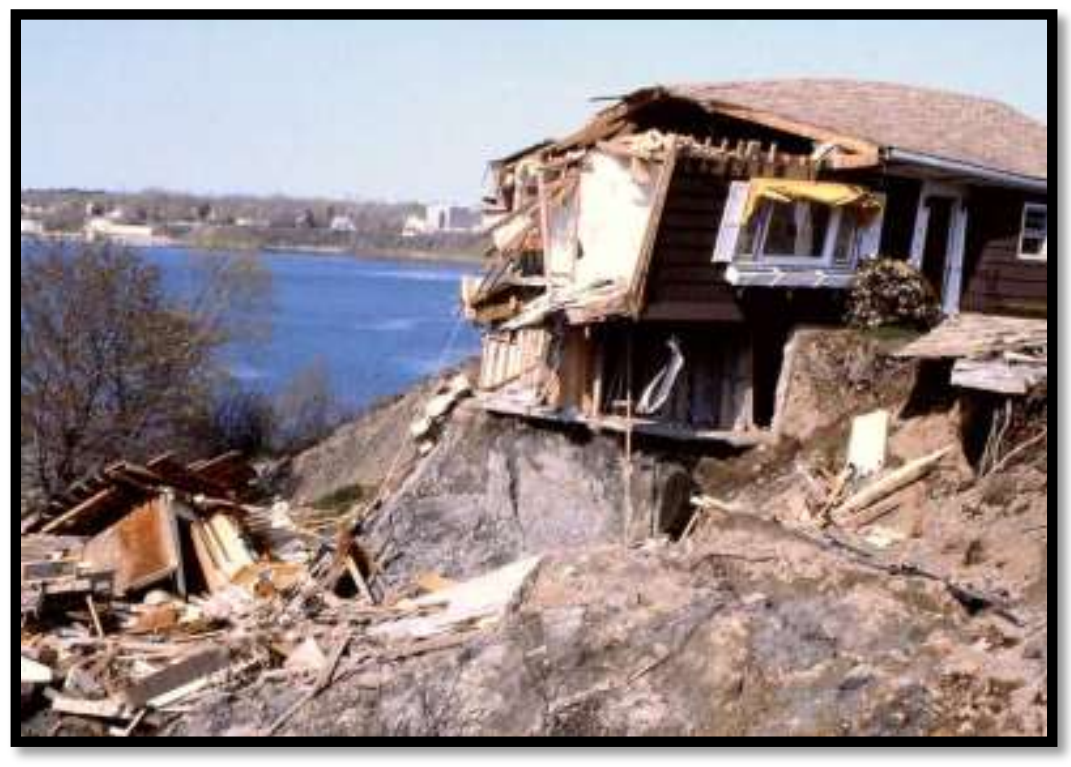

A clay bluff on the north shore of Rockland Harbor failed in 1996. This landslide formed a new scarp about 200 feet landward of the original top of the bluff in just a few hours. Two homes were destroyed. Photo: Maine Department of Agriculture, Conservation, and Forestry.

\section{LESSONS LEARNED AND RECOMMENDATIONS}

- Require planning at all levels. State mandates can improve local planning. Mandates are particularly effective when they identify clear prioritized goals, establish guidelines, and provide technical and financial support for local officials.

- Coordinate planning efforts. State and local governments need to coordinate their planning efforts and regulations. The goals at both levels need to be consistent and complementary in order to be effective. 


\section{FURTHER READING}

The Role of Coastal Zone Management Programs in Adaptation to Climate Change, Second Annual Report of the Coastal States Organization's Climate Change Work Group (2008).

noAa Office of Ocean and Coastal Resource Management, Adapting to Climate Change: A Planning GUIDE FOR STATE COASTAL MANAGERS (2010), available at http://coastalmanagement.noaa.gov/climate/adaptation.html.

Chad J. McGuire, Coastal Planning, Federal Consistency, and Climate Change: A Recent Divergence of Federal and State Interests, 27 NATURAL ReSOURCES AND ENVIRONMENT 1 (2012).

\section{REFERENCES}

${ }^{50}$ Rivers and Harbors Appropriation Act of 1899, 33 U.S.C. $\S 403,30$ Stat. $§ 1151$ (1899).

${ }^{51} / d$.

52 Id.

${ }^{53}$ United States v. Milner, 583 F.3d 1174 (9th Cir. 2009). See also, Leah Rindner, Forcing Adaptation through the Rivers and Harbors Act, 38 ECOLOGY LAW QUARTERLY 341 (2011), available at www.boalt.org/elq/documents/4Rindner.pdf.

${ }^{54}$ United States v. Milner, 583 F.3d 1174, 1188 (9th Cir. 2009)

${ }^{55}$ Coastal Barrier Resources Act, Public Law 97-348, 16 U.S.C. § 3501 et seq. (1982).

${ }^{56}$ See, U.S. Fish and Wildlife Service, Coastal Barrier Resources Act, http://www.fws.gov/cbra/Act/index.html (last visited Aug. 8, 2013).

${ }^{57}$ U.S. Fish and Wildlife Service, The Coastal Barrier Resources Act: Harnessing the Power of Market Forces to CONSERVE AMERICA'S COASTS AND SAVE TAXPAYER'S MONEY 2 (2002), available at www.fws.gov/cbra/Docs/TaxpayerSavingsfromCBRA.pdf.

${ }^{58}$ National Marine Sanctuaries Act, 16 U.S.C. $§ 1431$ et seq. (amended 2000).

59 NOAA, National Marine Sanctuaries Act Reauthorization, June 26, 2013, http://sanctuaries.noaa.gov/management/reauthorization.html (last visited Aug. 8, 2013).

${ }^{60}$ Coastal Zone Management Act of 1972, 16 U.S.C. $§ 1451$ et seq., 86 Stat. $§ 1280$ (1972).

${ }^{61}$ Id. $\S 1452(1)$.

62 Coastal Zone Management Program Regulations, 61 Code Federal Regulations § 923 (1996).

${ }^{63} 16$ U.S.C. § 1454.

6416 U.S.C. $\S 1455$.

6516 U.S.C. § $1455 a$. 
${ }^{66} 16$ U.S.C. $\S 1455 b$

6716 U.S.C. § $1456 \mathrm{~b}$.

${ }^{68}$ NOAA, FY 2012 Ocean and Coastal Resource Management Budget Allocations by Program, last updated Jan. 30, 2013, http://coastalmanagement.noaa.gov/funding/welcome.html (last visited Aug. 8, 2013).

69136 CONG. REC H8101 (daily ed. Sep. 26, 1990) (statement of Rep. Pallone) (“It is clear that under the CZMA, the whole idea is to have cooperation between the States and the Federal Government."). See also Martin LaLonde, Allocating the Burden of Proof to Effectuate the Preservation and Federalism Goals of the Coastal Zone Management Act, 92 MichigAN LAW REVIEW 438 (1993).

${ }^{70}$ See Chad J. McGuire, Coastal Planning, Federal Consistency and Climate Change: A Recent divergence of federal and state interests, 27 NatURAl ResourCES \& ENVIRONMENT (2012); Patrick J. Gibbons, Too Much of a Good Thing? Federal Supremacy \& the Devolution of Regulatory Power: The Case of the Coastal Zone Management Act, 48 NAVAL LAW REVIEW 84 (2001); John Duff, The Coastal Zone Management Act: Reverse Pre-Emption or Contractual Federalism?, 6 OCEAN ANd CoAstal LAW Journal 109 (2001). See also Bruce Kuhse, The Federal Consistency Requirements of the Coastal Zone Management Act: It's Time to Repeal This Fundamentally Flawed Legislation, 6 OCEAN AND COASTAL LAW JOURNAL 77 (2001) (arguing that the CZMA grants too much authority to the states, essentially resulting in reverse pre-emption).

71 U.S.C. $\S 1456$ (c)(3). The review procedures are similar but not exactly the same. The important element for this discussion is that the actions must be compliant with the State CMP. See also M. Kurtz, Managing Alaska's Coastal Development: State Review of Federal Oil and Gas Lease Sales, 11 ALASKA LAW REVIEW 377 (1994); Tim Eichenberg and Jack Archer, The Federal Consistency Doctrine: Coastal Zone Management and "New Federalism", 14 ECOLOGY LAW QUARTERLY 9, 14 (1987).

72 S. REP. No. 277, $94^{\text {th }}$ Cong., $1^{\text {st }}$ Sess. 9 (1975), reprinted in 1976 U.S.C.C.A.N. 1768, 1776, cited in LaLonde, supra note 69. See also McGuire, supra note 70; Gibbons, supra note 70.

${ }^{73}$ The original language of the CZMA required a consistency review only when federal actions had a direct effect on the coasts. 16 U.S.C. $\S 1456$ (c)(1). The Supreme Court in Secretary of the Interior v. California, 464 U.S. 312 (1984) interpreted that language to limit the scope of those federal actions that must comply with a State CMP. In 1990, Congress passed the Coastal Zone Management Act Reauthorization Amendments of 1990 and changed the language to require review of any Federal "activity within or outside the coastal zone that affects any land or water use or natural resource". 16 U.S.C. $\S 1456(c)(1)(A)$ (Supp. III 1991). "The Committee's principal objective in amending [section 307] is to overturn the decision of the Supreme Court in Secretary of the Interior v. California." 136 CONG REC. H8075 (daily ed. Sep. 26 1990), cited in LaLonde, supra note 69.

${ }^{74} 16$ U.S.C. $\S 1456 c(1)(C)$ (Supp. IV 1992); 15 C.F.R. § 930.34(b) (1993).

7516 U.S.C. § $1456(h)(1988)$.

7615 C.F.R. $\S 930.116$ (1991). The state is not required to attempt mediation before bringing suit. See also LaLonde, supra note 69.

7716 U.S.C. $\S 1456 \mathrm{c}(1)(\mathrm{B})$.

78 NOAA, Envisioning the Future of Coastal Management, revised May 9, 2008, http://coastalmanagement.noaa.gov/czm/czma vision.html (last visited Aug. 8, 2013).

${ }^{79}$ Coastal Coordination Act of 1991, 33 Texas Natural Resources Code $§ 201$ et. seq. (1991).

${ }^{80}$ Coastal Coordination Advisory Committee, Texas Coastal Management Program: 2012 Annual Report 2 (2012).

${ }^{81} / d$.

${ }^{82}$ Id. at 3.

${ }^{83}$ Id. at 4-5. 
${ }^{84}$ Id. at 7.

${ }^{85}$ Coastal Coordination Act of 1991, supra note 79, $§ 33.204(\mathrm{f})$; see also TEXAS COASTAL MANAGEMENT PROGRAM: 2012 ANNUAL REPORT, supra note 80, at 1, 27.

86 Department of Interior, Bureau of Ocean Energy Management, Alaska OCS Region, http://www.boem.gov/About-BOEM/BOEM-Regions/Alaska-Region/Index.aspx (last visited Aug. 9, 2013); see also U.S. Census Bureau, Statistical Abstract of the United States: 2012, Table 364: Coastline and Shoreline of the United States by State (2012).

${ }^{87}$ U.S. Census BUREAU, supra note 86.

${ }^{88}$ The Alaska Coastal Management Plan expired on June 30, 2011. NOAA Action Notice, Alaska Coastal Management Program Withdrawal from the National Coastal Management Program under the Coastal Management Zone Act (CZMA), 76 Federal Register 39857-39858 (July 7, 2011), available at http://www.gpo.gov/fdsys/pkg/FR-2011-07-07/html/2011-16987.htm.

${ }^{89}$ See, Lisa Demer and Kyle Hopkins, Alaska voters reject coastal zone measure, ANCHORAGE DAILY NEWS, Aug. 28, 2012, http://www.adn.com/2012/08/28/2603128/coastal-zone-measure-appears-doomed.html; Tim Brander, Coastal management initiative fails by a heavy margin, ALASKA JOURNAL OF COMMERCE, Aug. 31, 2012, http://www.alaskajournal.com/Alaska-Journal-of-Commerce/September-Issue-2-2012/Coastal-managementinitiative-fails-by-a-heavy-margin.

${ }^{90}$ Id. See also, Amanda Coyne, Oil companies spend big against Alaska coastal initiative, ALASKA DISPATCH, Aug. 21, 2012, http://www.alaskadispatch.com/article/oil-companies-spend-big-against-alaska-coastal-initiative.

${ }^{91}$ See, e.g., Jerzy Shedlock, Pros, cons of new coastal management program debated, JUNEAU EMPIRE, July 8, 2012, http://juneauempire.com/state/2012-07-08/pros-cons-new-coastal-management-program-

debated\#.Udx 5SvwIOM (last visited Aug. 12, 2013) (quoting State Representative Paul Seaton as saying, "This coastal management plan gives boroughs and certain unincorporated areas significant consultation as the feds make decisions on projects," an opportunity he felt would be lost without the Coastal Zone Management Project.).

${ }^{92}$ See NOAA, Alaska Withdraws from the National CZM Program, 6 COASTAL MANAGEMENT NeWs 5 (July 3, 2011).

${ }^{93}$ McGuire, supra note 70.

${ }^{94}$ See, e.g., Raymond Burby and Linda Dalton, Plans Can Matter! The Role of Land Use Plans and State Planning Mandates in Limiting the Development of Hazardous Areas, 54 PUBLIC AdMINISTRATION ReVIEW 229 (1994).

95 See, e.g., id; Raymond Burby and Peter May, Making Governments Plan: State Experiments in Managing LANd Use (Johns Hopkins University Press, 1997); Richard Norton, More and Better Local Planning: State-Mandated Local Planning in Coastal North Carolina, 71 Journal of the American Planning Association 55 (2005); I. BuRTON, R. Kates, and R. Sneed, The Human Ecology of CoAstal Flood Hazards in Megalopolis (University of Chicago Press (1969).

${ }^{96}$ See, e.g., Sierra Club, SMart Choices or Sprawling Growth: A 50-State Survey of Development (Sierra Club Foundation, 2000).

97 See, e.g., National Association of Home Builders, Smart Growth: Building Better places to Live, Work and Play (2000).

${ }^{98}$ See, e.g., American Planning Association, Policy Guide on Smart Growth (2012); American Planning Association, Policy Guide on Planning for Sustainability (2000); American Planning Association Policy Guide on Climate Change (2011) (noting that "Given the regional nature of climate change impacts, state and local governments are often the most appropriate levels of government to develop plans, incentives, standards, and regulations to address climate change mitigation and adaptation").

${ }^{99}$ See, e.g., Zhenghong Tang, Michael Lindell, Carla Prater, Ting Wei, and Christopher Hussey, Examining Local Coastal Zone Management Capacity in U.S. Pacific Coastal Counties, 39 CoASTAL MANAGEMENT 105, 124 (2011); S.D. 
Brody, Are we learning to make better plans? A longitudinal analysis of plan quality associated with natural hazards, 23 JouRnal of PLANNIng EduCATION AND RESEARCH 191 (2003).

${ }^{100}$ See, e.g., Michael McGinnis and Christina McGinnis, Adapting to Climate Impacts in California: The Importance of Civic Science in Local Coastal Planning, 39 COASTAL MANAGEMENT 225 (2011).

${ }^{101}$ See BURBY AND MAY, supra note 95; Philip R. Berke and Steven P. French, The Influence of State Planning Mandates on Local Plan Quality, 13 Journal of PLANNING EduCATION AND RESEARCH, 237, 242 (1994); Raymond Burby, Philip Berke, Linda Dalton, J. DeGrove, Steven French, E. Kaiser, et al., Is State-Mandated Planning Effective? 45 LAND USE LAW AND ZONING DIGEST 3 (1993); Linda Dalton and Raymond Burby, Mandates, Plans and Planners: Building Local Commitment to Development Management, 60 Journal of THE AMERICAN PLANNING AsSoCiATION 444 (1994).

102 BURBY AND MAY, supra note 95, at 105-106.

${ }^{103}$ See Philip R. Berke and Steven P. French, The Influence of State Planning Mandates on Local Plan Quality, 13 Journal of PLANNINg Education ANd ReSEARCH, 237, 242 (1994), citing Peter May, Regulatory federalism: State mandate design and hazard mitigation. Paper presented at the annual meeting of the Western Political Science Association, March 19-22 (1992).

${ }^{104}$ See Malcom Goggin, ann Bowman, James Lester, and Laurence O’Toole, Implementation theory and Practice, ToWARD A THIRD GeneRATION (Scott Foresman, 1990); McGinnis, supra note 100.

${ }^{105}$ Berke and French, supra note 103. See also D. McFarlane, Testing the statutory coherence hypothesis, 20 ADMINISTRATION AND SOCIETY 395 (1989).

${ }^{106}$ See D. MAZMANiAn ANd P. SABATIER, IMPLEMENTATION AND Public Policy (1983); P. Sabatier, Top-down and bottom-up approaches to implementation research: A critical analysis and suggested synthesis, 6 JOURNAL OF PUBLIC POLICY 21 (1986).

${ }^{107}$ See J. Scholz, Cooperative regulatory enforcement and the politics of administrative effectiveness, 85 AMERICAN PoltTICAL SCIENCE ReVIEW 115 (1991); D. Hedge, D. Menzel, and M. Kraus, The intergovernmental milieu and streetlevel implementation, 70 SOCIAL SCIENCE QUARTERLY 285 (1989).

${ }^{108}$ Berke and French, supra note 103, at 247 (emphasis added).

${ }^{109}$ See id.; J. Scholz, Cooperation, deterrence, and the ecology of regulatory enforcement, 18 LAW AND SOCIETY REVIEW 179 (1984).

${ }^{110}$ Berke and French, supra note 103, at 242-243.

${ }^{111}$ See, e.g., Burby and Dalton, supra note 94, at 232 (concluding "when plans recommended limitations on development, policy makers tended to adopt those recommendations").

112 BURBY AND MAY, supra note 95, at 105.

${ }^{113}$ Burby and Dalton, supra note 94; see also Norton supra note 95.

${ }^{114}$ Burby and Dalton, supra note 94.

${ }^{115}$ See Raymond Burby, Making Plans That Matter: Citizen Involvement and Government Action, 69 JOURNAL OF THE AMERICAN PLANNING ASSOCIATION 33 (2003).

${ }^{116}$ See, e.g., Edmund Burke, A Participatory Approach to Urban Planning (Human Science Press, 1979); Diane Day, Citizen Participation in the Planning Process: An Essentially Contested Concept?, 11 Journal OF PLANNING LITERATURE 421, 424-426 (1997); Thomas Beierle and Jerry Cayford, Democracy in Practice: Public Participation in EnVIronmental DeCISIONS (2002) 21-33; Laurie Pearce, Disaster Management and Community Planning, and Public Participation: How to Achieve Sustainable Hazard Mitigation, 28 NATURAL HAZARDS 211, 218 (2003). 
117 See, e.g., Benigno Aguirre, Planning, Warning, Evacuation and Search and Rescue: A ReVieW of the Social SCIence Research Literature 5 (Texas A\&M University, 1994); Rene A. Monnikhof and Jurian Edelenbos, Into the Fog? Stakeholder Input in Participatory Impact Assessment 19 IMPACT ASSESSMENT AND PROJECT APPRAISAL 29 (2001).

${ }^{118}$ See, e.g., Raymond Burke and Peter May, Intergovernmental Environmental Planning: Addressing the Commitment Conundrum, 41 Journal of Environmental Planning And Management 95 (2010); see also P. Healy, Development Plans: New Approaches to Making Frameworks for Land Use Regulation, 2 EUROPEAN PLANNING JOURNAL 39 (1994); James Creighton, Involving Citizens in Community DeCision Making. A Guidebook (Program for Community Problem Solving, 1992).

${ }^{119}$ N.C. Gen. Stat. $§ 113 A-106$ to -112 (1993)

${ }^{120}$ Id. at $§ 113-\mathrm{A}-11$.

${ }^{121}$ North Carolina CoAstal Futures Commission, Charting a COURSE fOr Our CoAst: A Report to the GovernOR (1994).

122 North Carolina Coastal futures Commission, a Progress Report on the Coastal futures Committee's Recommendations for CoAstal Management 1-5 (1999).

${ }^{123}$ Id. at 4. See also Hannah Holm, The Evolution of State Initiatives in North Carolina, POPULAR GOVERNMENT 21,21 (Fall 2000) (stating that "There also is no requirement that state funding for growth-related infrastructure projects be spent only in areas predesignated for urban growth, as there is in Maryland.").

${ }^{124}$ See COASTAL FUtURES COMMISSION, PROgRESS REPORT, supra note 122 , at 1.

${ }^{125}$ See Holm, supra note 123 , at 23.

${ }^{126}$ See COASTAl Futures COMmission, Progress RePORT, supra note 122, at 1; see also Norton, supra note 95 , at 5 (stating that the reason for the moratorium and review was that the "program erupted in controversy in mid-1998 when the CRC temporarily refused to certify a local plan based on environmentalists' complaints").

127 North Carolina Estuarine Shoreline Protection Stakeholder Process, Protecting north Carolina's Coastal RESOURCES: A FRAMEWORK FOR MAINTAINING AND IMPROVING WATER QUALITY 20 (1999).

${ }^{128}$ Norton, supra note 95 , at 7.

${ }^{129}$ See id.

130 North Carolina Coastal Resource Commission Science Panel on CoAstal hazards, north Carolina Sea-level Rise ASSESSMENT REPORT (March 2010).

131 Id. at 11 .

132 Id. at 12 .

${ }^{133}$ See, Jane Lee, Legislating Sea Level Rise, AMERICAN ASSOCIATION FOR THE AdVANCEMENT Of SCIENCE, June 12, 2012, http://news.sciencemag.org/environment/2012/06/legislating-sea-level-rise (last visited Aug. 12, 2013).

${ }^{134}$ See, e.g., S. Jevrejeva, A. Grinsted, J.C. Moore, and S. Holgate, Nonlinear trends and multiyear cycles in sea level records, 111 Journal of Geophysical Research: OCEANs (1978-2012), C9 (2006); John A. Church and Neil J. White, $A$ 20th century acceleration in global sea-level rise, 33 GEOPHYSICAL RESEARCH LETTERS L01602 (2006); Thomas, Rignot, E. Rignot, Gino Casassa, P. Kanagaratnam, César Acuña, T. Akins, Henry Brecher et al., Accelerated sea-level rise from West Antarctica, 306 SCIENCE 255 (2004).

${ }^{135}$ Figure ES1. Global Sea Level Rise Scenarios for the United States National Climate Assessment, NOAA Technical Report OAR CPO-1, Dec. 6, 2012, http://scenarios.globalchange.gov/sites/default/files/NOAA SLR r3 0.pdf.

136 House Bill 819, Fourth Edition June 12, 2012, Proposed Conference Committee Substitute H819-PCCS80412-SB6, available at http://www.ncleg.net/gascripts/billookup/billlookup.pl?Session=2011\&BillID=H819. 
137 Alon Harish, New Law in North Carolina Bans Latest Scientific Predictions of Sea-Level Rise, ABC NEWS, Aug. 2, 2012, http://abcnews.go.com/US/north-carolina-bans-latest-science-rising-sea-level/story?id=16913782 (last visited Aug. 12, 2013).

${ }^{138}$ Quoted in Wade Rawlins, North Carolina lawmakers reject sea level rise predictions, REUTERS, JUly 3, 2012, http://www.reuters.com/article/2012/07/03/us-usa-northcarolina-idUSBRE86217/20120703 (last visited Aug. 12, 2013).

${ }^{139}$ Mandatory Shoreland Zoning Act (MSZA), 38 M.R.S.A. $\S \S 435-449$ (1971).

140 Id. at $§ 435$.

${ }^{141}$ State of Maine Guidelines for Municipal Shoreland Zoning Ordinances: 06-096 Department of Environmental Protection, Part 1000, available at www.maine.gov/sos/cec/rules/06/096/096c1000.doc.

142 MSZA, supra note 139 , at $\S 438-A(4)$.

${ }^{143}$ Maine Department of Environmental Protection, Mandatory Shoreland Zoning: State Imposed Ordinance Chapters, http://www.maine.gov/dep/land/slz/\#stat (last visited Aug. 9, 2013). 


\section{CHAPTER 2}

\section{Rolling Setbacks and Public EASEMEnts}

Setbacks, buffers, and public easements all require private property owners to locate structures on shoreline lots some distance from the actual shore. They can be structured to "roll" a set distance from the shore, which allows them to automatically account for shoreline erosion and sea level rise without requiring substantial recurring action on the part of state or local agencies.

Setbacks, buffers, and rolling easements are able not only to protect shoreline properties by reducing their exposure to coastal floods and storms but also to enact long-term managed retreat from the coasts and prevent repetitive losses. Homes located on shoreline properties will still be exposed to some danger from coastal storms (especially as storms increase in intensity due to climate change), but the setback requirements provide a balance between development and protection by allowing property owners to build and remain near the coasts until the risks become unacceptably high.

Rolling setbacks and public easements are discussed together in this chapter because the mechanisms underlying these tools are similar, but the two approaches differ in the rights they convey. A setback conveys no rights to the public. Rather, it is a building siting restriction. A public easement, conversely, in this context actually grants the public a right of access to a portion of the beach front property. Easements may therefore be subject to greater takings challenges than setbacks, as will be discussed below.

\section{Public Trust Doctrine}

The Public Trust Doctrine was first codified by the Romans in $500 \mathrm{AD}$, took root in English law, and was subsequently brought to the colonies. ${ }^{144}$ It is therefore one of the oldest principles in American law. The essence of the Public Trust Doctrine is that the waters of the state (and the lands beneath them) are a public resource to be managed in trust by the government on behalf of the public and that all citizens have a right to access the waters. This trust is not invalidated by private ownership of the shores and cannot be abandoned by the state. ${ }^{145}$

In 1953 the U.S. Submerged Lands Act confirmed state ownership and control of all lands situated

The ability of the public to have access to and use of coastal lands, water and resources is a right that predates the founding of this country and has been woven into the fabric of our basic rights and principles.

- New Jersey Department of Environmental Protection 
below the mean low water line. ${ }^{146}$ Most states also recognize a public trust right to tidal waterways extending up to the mean high water mark. ${ }^{147}$ A few states, however, limit the public trust to only those lands below the mean low water mark (Delaware, Maine, Massachusetts, Minnesota, Pennsylvania, and Virginia). ${ }^{148}$ New Jersey and Texas have the most expansive public trust doctrine, encompassing the dry sand beach up to the first line of vegetation. $^{149}$

\section{Public Trust and Beach Nourishment}

The mean high water and low water lines - and the relative public and private rights they confer - fluctuate with the state of the beach and tides. As shores erode and sea levels rise, the mean high water mark (and, later on, the mean low water mark) will move slowly shoreward. This means that the coastal property will shrink in size and the public will gain more submerged land. Conversely, if water levels were to fall or a beach to grow, a private owner could gain extra feet of property.

Laws that fix a boundary between private and public lands may encounter problems when sea level rises beyond that boundary: do the submerged lands shoreward of the fixed boundary belong to the private owner or the public? A number of states have specific statutory provisions that provide that any land built through artificial beach nourishment activities belongs to the state. ${ }^{150}$ The Florida Supreme Court recently held that the erosion control line established by state law will remain fixed only so long as the state maintains a dry public beach seaward of that line. ${ }^{151}$ And the U.S. Supreme Court agreed that the government had a right to fill in the submerged lands it owned, and that this did not violate any rights of the coastal landowners (even though it meant their beach front properties were beach front no longer). ${ }^{152}$ Lawmakers introducing new legislation should include language to clarify the future relationship between private lands and public trust. 
Stop the Beach Renourishment, Inc. v. Florida Department of Environmental Protection, et al. 560 U.S. 130 S. Ct. 2592, 177 L. Ed. 2d 184 (2010)

Destin and Walton County were granted permits by the Florida Department of Environmental Protection to restore 6.9 miles of beach by filling in submerged lands and adding 75 feet of dry sand seaward of the former mean high tide line. Florida's Beach and Shore Preservation Act governed beach restoration and maintenance (nourishment) and authorized the Department to set an "erosion control line" where the old mean high water mark had been. This new "erosion control line" then becomes the boundary between private property and public, state-owned property.

Several owners of beachfront property in the area formed a nonprofit corporation, Stop the Beach Renourishment, Inc., to fight the project. They objected because the addition of 75 feet of sand would mean that their beach front properties would no longer be directly on the coast.

Coastal landowners in Florida have certain "special rights" with regard to the water, including the right to an unobstructed view of the water and the right to receive accretions to their property. The owners argued that the beach renourishment program would deprive them of their right to future accretions to their property if the shore should move seaward.

The Florida Supreme Court rejected this argument. It held that under Florida law, if the submerged lands became dry due to a hurricane or other avulsion, the lands would still belong to the state. This remains true even if the state causes the avulsion. Therefore, the state, as a property owner, could choose to fill in its submerged lands if it wanted. Once a strip of land had been added to the shore through avulsion, the landowner no longer had a right to subsequent accretions: the sand would be accreting on the state's land, not on the private land.

The U.S. Supreme Court agreed. There could be no taking unless the property owners could show a right to future accretions or a right to contact with the water that was superior to Florida's right to fill in its lands. According to Justice Scalia, delivering the opinion of the court, "the showing cannot be made."
Accretion - addition or removal of sand or sediment over a long period of time, so slowly that one cannot see the change occurring, but the difference becomes apparent over time

Avulsion - a sudden loss or addition of land, usually in a large amount 


\section{SETBACKS}

Setbacks protect new development from slow-onset sea level rise and shore erosion by siting buildings on the upland portions of coastal property lots. Setbacks may also provide some protection against harm from coastal storms, though the relatively close proximity of buildings to the shore will still present significant risks. Setbacks may be established through state legislation or municipal codes.

Although setbacks are most often used to protect coastal development and coastal ecosystems, the U.S. Supreme Court has also upheld the use of setbacks to further the goals of open space and access to light and air. ${ }^{153}$

Setbacks are building restrictions that establish a distance from a boundary line with which a land owner is prohibited from building or expanding structures.

Buffers require landowners to leave portions of their property undeveloped in order to ensure that adjacent development does not impact natural processes.

Setbacks provide long-term economic benefit by avoiding repetitive loss and repairs. And setbacks may provide short-term economic benefits by making coastal structures safer and thereby eliminating the need to invest in costly coastal armoring (see also Chapter 3 on the benefits of Preventing Coastal Armoring). Avoiding coastal armoring and the associated damage to natural beach ecosystems is particularly important in states that depend on beach tourism, the largest tourism industry in the United States. ${ }^{154}$ This will be discussed in further depth in the Kaua'i, HI, example below.

\section{Establishing a Setback Distance}

The most difficult aspect of establishing a setback is determining the appropriate setback distance. There are two main methods for establishing a setback line: set distances and erosion rates.

Set distances are sometimes called arbitrary setback lines and these are a standardized set distance from a specific feature (e.g., 40 feet from the mean high tide line).

Erosion rate setbacks are based on an observed or projected annual erosion rate of the shoreline (e.g. 70 times the annual coastal erosion rate).
Arbitrary setback lines are simpler to establish, as they simply require a statute or legislation to declare a minimum distance from a tideland landmark or the shoreward edge of the property. However, set distances may be over- or underambitious. If a distance is too small it will not provide adequate protection to homes. If it is too large, it may unnecessarily restrict development. This will depend to some extent on the rate of erosion and sea level rise in a given region. ${ }^{155}$

This problem can be addressed by a routine updating of setback distances, if a responsible 
agency or official has been given the authority. In South Carolina, for example, setback lines and erosion rate data are updated every 8 to 10 years. ${ }^{156}$

An alternate solution is to use setback distances based on historic or projected annual erosion rates. North Carolina and Florida have both established setbacks based on erosion rates. North Carolina's Administrative Code for Ocean Hazard Areas ${ }^{157}$ establishes a setback rate from the first line of vegetation that depends on the size of the structure.

It must be noted that neither set nor erosion-rate based setbacks account for natural disasters or large coastal storms. Setbacks may provide some level of risk reduction but are best suited for dealing with long-term, slowonset erosion and sea level rise.

For all structures less than 5,000 square feet, the setback requirement is 30 times the long-term average annual erosion rate. For structures between 5,000 and 9,999 square feet, the setback is 60 times the rate, and for structures above 10,000 square feet, the setback increases according to size to a maximum of 90 times the erosion rate. ${ }^{158}$ The erosion rate is specific to each part of the coastline and is determined through a complex study conducted by the Department of Environment and Natural Resources (in North Carolina rates vary from less than 1 foot per year to more than 8 feet per year). ${ }^{159}$ Establishing an erosion rate is a complicated and time consuming task. It requires dedicated personnel and funding as well as historic erosion data.

A number of states, rather than or in addition to updating their erosion rate data at routine intervals, use a combination of arbitrary setback and erosion rate distances. For example, North Carolina's setbacks are based on erosion rate data, but the statute also contains a minimum setback of 60 to 180 feet, depending on building size. ${ }^{160}$ Developers must build to either the erosion rate or the set distance, whichever is greater.

In Minnesota, the North Shore Management Plan (NSMP) - a joint powers project among ten local governments - used a hybrid of erosion rates and set distances. Where erosion rates

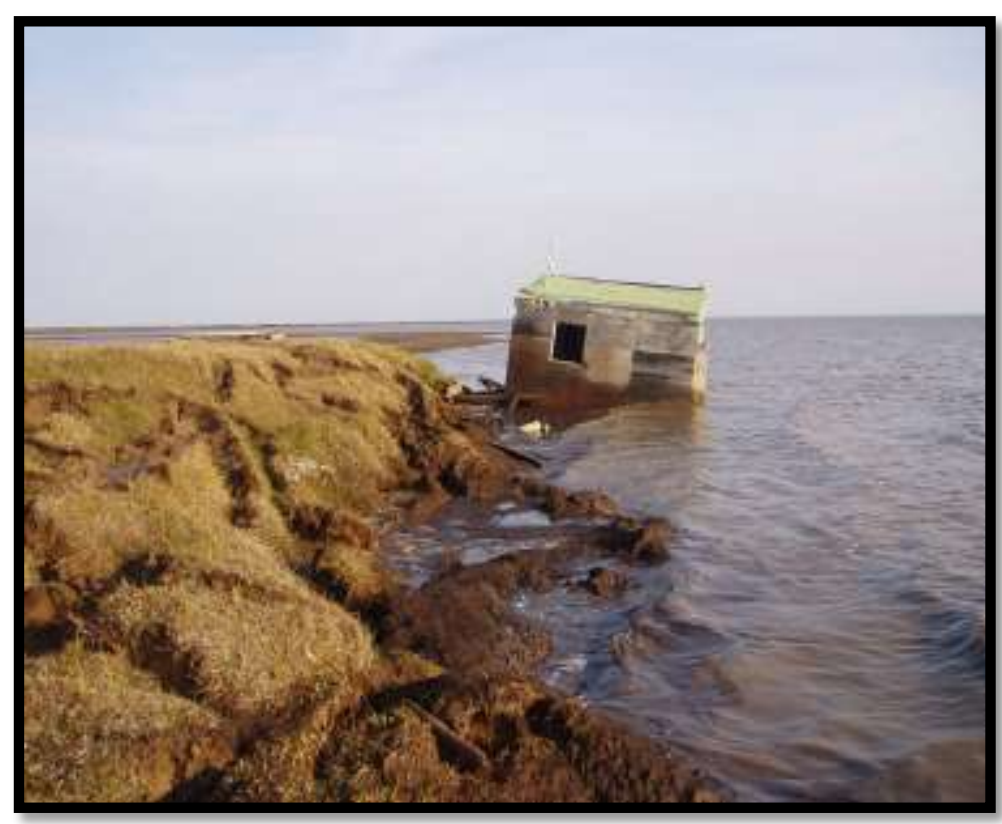
were known, the plan required a setback of 50 times the erosion rate plus 25 feet, and where erosion rates were unestablished, the setback was set at a standard 125 feet. $^{161}$

A CABIN ALONG ALASKA'S ARCTIC COAST WASHED INTO THE OCEAN BECAUSE THE BLUFF BENEATH IT ERODED AWAY. PHOTO: BENJAMIN JONES, USGS. 


\section{Takings Issues - Economic Value of Property}

In the seminal case Lucas $v$. South Carolina Coastal Council, ${ }^{++}$the U.S. Supreme Court specifically addressed the takings issues related to setbacks. In 1986, David Lucas purchased two vacant beachfront lots in Charleston, SC. At the time, building single family homes on the lots was allowed, and Lucas planned to develop his lots in this way. However, in 1988 the South Carolina legislature passed the Beachfront Management Act, ${ }^{162}$ which established a 40 year policy of retreat and implemented this policy through a setback 40 times the average erosion rate. ${ }^{163}$ In

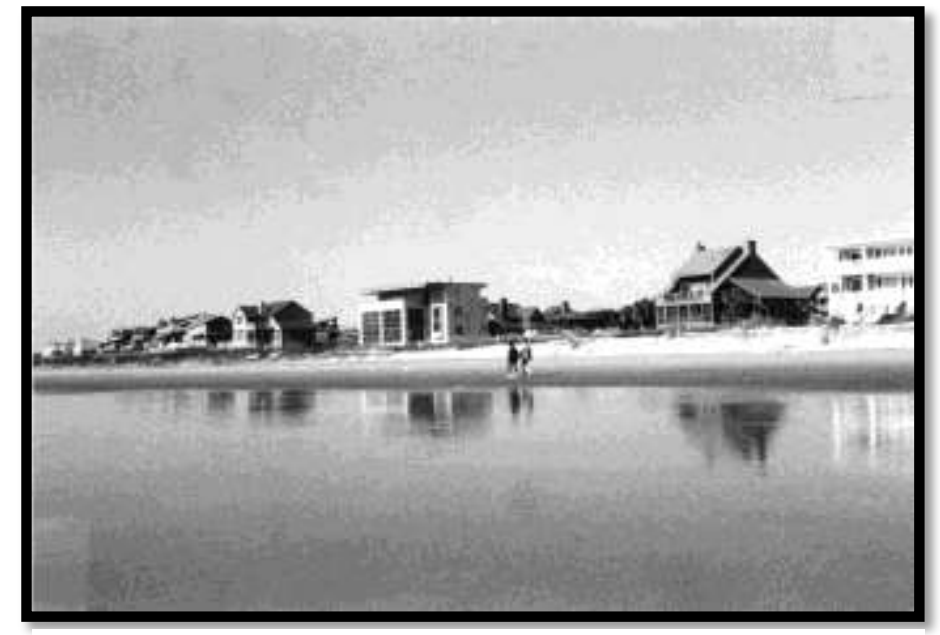

Lucas' lots in South Carolina as of Nov. 1994. Photo: William A. Fischel, Dartmouth College, by permission. effect, this prevented Lucas from developing his lot, which the Supreme Court found had deprived Lucas of "all reasonable investment-backed expectations" in his property. The regulation was found to be a taking, and the state was required to pay Lucas compensation. ${ }^{164}$

Lucas is often cited for the principle that a regulation may not deprive a landowner of $\underline{\text { all }}$ economic value in the property. However, the actual determination as to whether a regulation has removed all value or only diminished the property in value is difficult, and the outcome varies from state to state. In Maine, for example, the Maine Supreme Court found that property owners could still use shorefront property for recreational activities and so the property had not been deprived of all its economic value (see further discussion in Chapter 4 on Building Restrictions). ${ }^{\ddagger \ddagger}$

Governments can minimize the risk of facing a takings challenge by enacting setbacks as soon as possible so that potential developers are put on notice (reducing their "investmentbacked expectations") or by including a "savings" clause: a permitting process or other means by which the setback would not be applied so as to remove all economic value. ${ }^{165}$

\section{$\underline{\text { Minimum Lot Sizes }}$}

Setbacks are more likely to be problematic in areas where lot sizes are small and the setback may entirely preclude building on the lot, rather than requiring structures to be located near the back of a larger lot. Governments can mitigate this issue by requiring minimum lot sizes. The Minnesota Administrative Rules, for example, set forth minimum lot sizes for development on lakefronts. ${ }^{166}$

\footnotetext{
${ }^{+\dagger} 505$ U.S. 1003 (1992).

${ }^{\ddagger \ddagger}$ Wyer v Board of Environmental Protection, 747 A.2d 192 (Me. 2000).
} 


\section{Florida's Coastal Construction Control Line \& HuRricane OPAL}

In the 1980s, recognizing the threat of hurricanes to coastal properties, the Florida Department of Environmental Protection established a Coastal Construction Control Line (CCCL). ${ }^{167}$ The CCCL defines the zone along the coast that is vulnerable to a 100 year storm, and structures built seaward of the CCCL must obtain a permit from the Department and must meet strict siting and design requirements. ${ }^{168}$ These requirements include elevation and construction standards that are even stricter than the NFIP coastal V-zone requirements as well as enhanced wind-load standards beyond. ${ }^{169}$

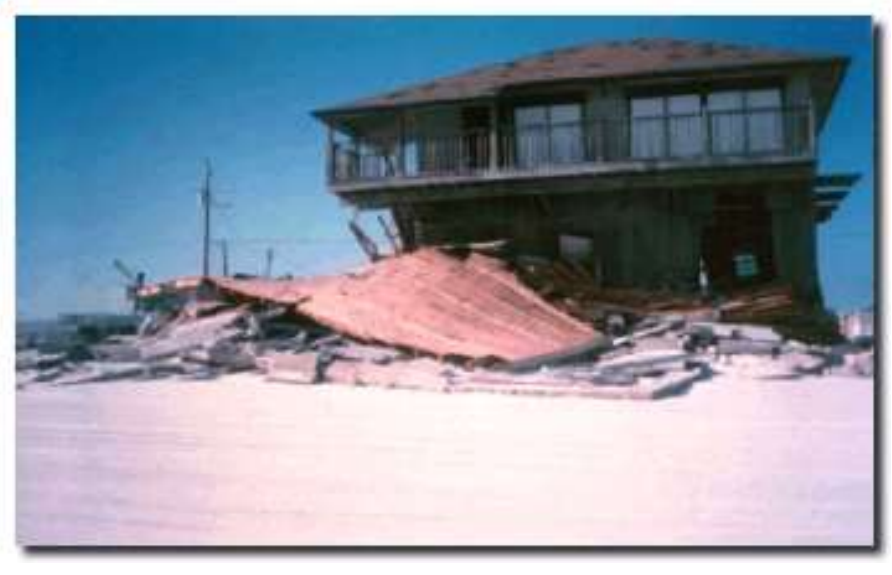

Damage from Opal. Photo: FL Department of Environmental Protection

On October 4, 1995, Hurricane Opal struck the Florida coastline as a Category 3 hurricane with 111 to 115 mile per hour winds. Of the 1,366 pre-existing structures seaward of the CCCL (structures built before the $\mathrm{CCCL}$ was put in place and therefore not subject to its stricter building requirements), 768 (or 56\%) were destroyed. ${ }^{170}$ On the other hand, only 2 of the 576 structures that complied with the $\mathrm{CCCL}$ building requirements were destroyed $(0.2 \%) .^{171}$

Florida has strengthened its $\mathrm{CCCL}$ program by combining it with a setback line that prohibits major structures seaward of a 30year erosion projection line (the expected position of the seasonal high water line 30 years from the date of the construction). ${ }^{172}$

\section{KAUAI, HaWAII - STATE \& LOCAL EFFORTS}

Kaua'l is the fourth largest of island of Hawaii and home to 113 miles of coastline - the kind of coastline that draws 7 million tourists to Hawaii each year and accounted for \$12.6 billion in $2011 .{ }^{173}$ Tourism accounts for more than $60 \%$ of all jobs in Hawaii. ${ }^{174}$ However, more than $70 \%$ of the beaches on Kaua'l are eroding. ${ }^{175}$

Recognizing the economic, cultural, and environmental importance of their beaches, in 2008 the Kaua'i county government adopted the Shoreline Setback and Coastal Protection Ordinance \#863. The ordinance explicitly notes that "The shoreline environment is one of Kaua'i's most important economic and natural resources," and explains the need for regulation: "beaches and coastal areas are part of the public trust, and it is government's fiduciary responsibility to protect beaches and coastal areas. ${ }^{176}$ 
The ordinance uses a combination of set distances and erosion rates depending on building size and lot size. If the lot is less than 160 feet in depth from the shore, then new buildings must be set back a set distance from the shore (40-100 feet) in proportion to the length of the lot. If the lot depth is greater than 160 feet, then the setback is based on an annual erosion rate. For structures less than 5,000 square feet, the structure must be set back 70 times the erosion rate plus a buffer of 40 feet. For buildings greater than 5,000 square feet, the setback increases to 100 times the annual erosion rate plus 40 feet. $^{177}$

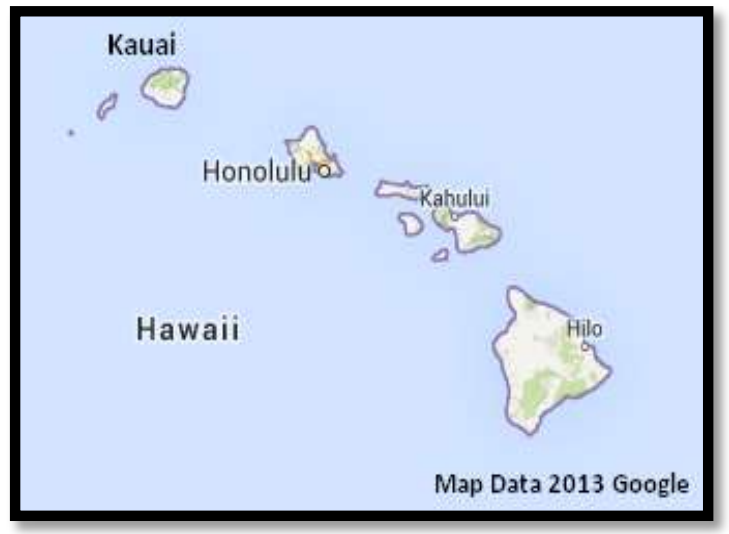

In addition, the ordinance prohibits efforts to "artificially fix the shoreline." If a structure is built seaward of the setback line (having acquired a variance), it is ineligible for protection by shoreline hardening for the life of the structure. These provisions are meant to protect the island's beaches against the detrimental effects of coastal armoring and to prevent property owners from relying on coastal hardening to protect their developments.

Similarly, state regulations, under the Hawaii Coastal Zone Management Program Policies for 'Beach Protection,' 178 prohibit the "construction of private erosion-protection structures seaward of the shoreline, except when they result in improved aesthetic and engineering solutions to erosion at sites and do not interfere with existing recreational and waterline activities; and (C) minimize the construction of public erosion-protection structures seaward of the shoreline" (emphasis added).

Despite these statutory provisions against armoring, shoreline armoring has continued to occur. This is due, at least in part, to "weak linkages between state and county agencies responsible for beach and shore conservation. Hawaii, in effect, has no widely accepted program, or plan related to beach conservation." 179 These weak linkages are due to confusing jurisdictional overlap at the coast. In Hawaii, the state has jurisdiction over lands seaward of the "shoreline," 180 and the way in which shoreline is defined can place this boundary far inland of the sites where erosion is occurring. The state has continued to permit coastal hardening in these areas, ${ }^{181}$ and state actions may therefore be at odds with local plans. Chapter 205 of the Hawaii Revised Statutes, Land Use Commission, allows counties to extend their jurisdiction to seaward of the mean sea level, but no county has done so to date. ${ }^{182}$

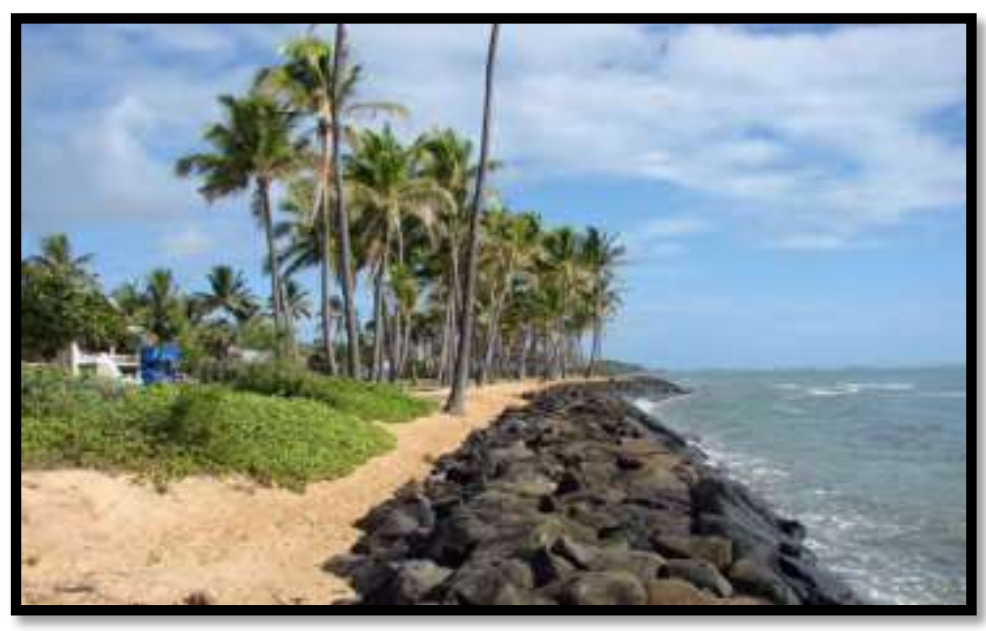

Reduction of beach on Kaua'i due to armoring. Photo: NOAA 
As a result of these problems, Hawaii has suffered extensive shoreline erosion due to coastal armoring. On the island of Oahu, U.S. Geologic Survey and University of Hawaii scientists concluded that "the reliance upon shoreline armoring to mitigate coastal erosion on Oahu has, instead, produced widespread beach erosion resulting in beach narrowing and loss." ${ }^{183}$ In fact, armoring had resulted in the loss of over 9 kilometers of sandy beach, $8 \%$ of the original 72 miles of sandy beach on Oahu, and $95 \%$ of that loss occurred in areas with coastal armoring. ${ }^{184}$ Greater coordination between state and county governments will be required to create a unified plan for the future of Hawaii beaches.

\section{California Coastal ACt}

In California, erosion of coastal bluffs is the primary motivator behind setback restrictions. The California Coastal Commission is one of three agencies that together administer the CA Coastal Management Program. ${ }^{185}$ Implementation of the California Coastal Act of $1976^{186}$ is primarily accomplished through the preparation of Local Coastal Programs (LCPs) by local authorities. ${ }^{\S}$ All coastal communities are required to prepare a plan, which must then be reviewed and approved by the Commission. These plans "contain the ground rules for future development and protection of coastal resources." ${ }^{187}$

As the Commission has the authority to approve or reject LCPs, the Commission also has the authority to require setbacks. ${ }^{188}$ In the context of coastal bluff development, the Commission has established a practice of correcting any LCP that does not include a setback of at least 25 feet for bluffs that are subject to coastal erosion. $^{189}$ Setback requirements may also be added with respect to wetlands and other sensitive habitats. As stated in a Land Use Plan (LUP) Update authored by Commission staff:

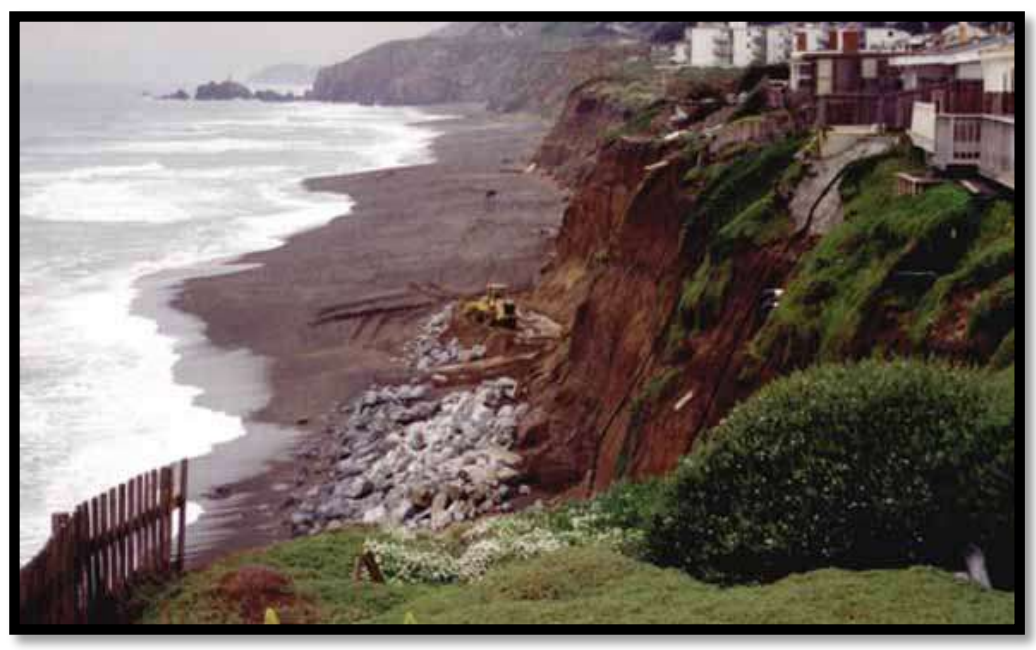

Pacifica California, 1997, along the 30 meter tall sea cliffs. Photo: USGS

Setbacks must be established in the LUP in order to determine how development will affect significant coastal resources including, but not limited to, bluffs, ESHA, wetlands, public access and recreation areas, and public views. ${ }^{190}$

\footnotetext{
${ }^{\S}$ An LCP includes a LUP, which may be the relevant portion of the local general plan, and any maps necessary to administer it, and the zoning ordinances, zoning district maps, and other legal instruments necessary to implement the land use plan.
} 
Setback distances in California LCPs are determined based on the expected life of the structure and known erosion rates. For example, Mendocino County's LCP ${ }^{191}$ states:

3.4-7: Setbacks shall be of sufficient distance to eliminate the need for shoreline protective works. Adequate setback distances will be determined from information derived from the required geologic investigation and from the following setback formula:

\section{Setback (meters) = Structure life (years) $x$ Retreat rate (meters/year)}

The retreat rate shall be determined from historical observation (e.g., aerial photographs) and/or from a complete geotechnical investigation.

Marin County's LCP ${ }^{192}$ stated that new structures "shall be set back from the bluff edge a sufficient distance to reasonably ensure their stability for the economic life of the development and to eliminate the need for shoreline protective works." 193 This assurance is provided by a calculation that takes into account the economic life of the structure and also factors in a minimum safety factor:

Determination of bluff setbacks. Adequate bluff setback distances will be determined based on the information provided in the geologic report required pursuant to Section 22.64.060.A.2 and the following setback formula (where 100 years represents the economic life of a structure and 1.5 represents a minimum safety factor):

\section{Setback (meters) $=100$ (years) $\times$ Retreat Rate (meters/year) + setback to achieve a slope stability Factor of Safety of at least 1.5 (minimum factor of safety) $)^{194}$}

Marin County's plan is also notable for including a statement that "predicted bluff retreat shall be evaluated considering only historical bluff retreat data, but also acceleration of bluff retreat due to continued and accelerated sea level rise, and other climate impacts according to best available science." ${ }^{195}$

In order to help local planners determine what the "best available science" on sea level rise and climate change might be, in 2013, the California Ocean Protection Council issued a State of California Sea-Level Rise Guidance Document. ${ }^{196}$ The Document made eight recommendations for the inclusion of sea level rise in coastal planning:

1. Use the ranges of SLR presented in the June 2012 National Research Council report on Sea-Level Rise for the Coasts of California, Oregon, and Washington as a starting place and select SLR values based on agency and context-specific considerations of risk tolerance and adaptive capacity. 
2. Consider timeframes, adaptive capacity, and risk tolerance when selecting estimates of SLR.

3. Consider storms and other extreme events.

4. Coordinate with other state agencies when selecting values of SLR and, where appropriate and feasible, use the same projections of sea-level rise.

5. Future SLR projections should not be based on linear extrapolation of historic sea level observations.

6. Consider changing shorelines.

7. Consider predictions in tectonic activity.

8. Consider trends in relative local mean sea level.

Although some of the details in the document are California-specific, the recommendations in their broad form provide a good foundation for coastal planners in any state. Other states should consider issuing similar guidance with state-specific information for their own planners.

\section{Enforcement}

Setbacks are only an effective means of promoting wise development and managed retreat if the setback requirements are enforced. The California Coastal Commission is authorized to take action against any property developer who:

Fails to obtain a Coastal Development Permit before construction; or Fails to comply with the conditions of the coastal development permit approval and to remedy violations of those development permits (including restoring sites to their "pre-violation" condition). ${ }^{197}$

The Commission first issues a "cease-and-desist" notice for a Coastal Act violation, and if the order is not complied with, the Commission can pursue enforcement in county courts, who are authorized to issue fines up to $\$ 30,000 .{ }^{198}$ The Coastal Act also provides for citizen suits to address violations and to enforce Commission orders. ${ }^{199}$ However, working through the courts can be a lengthy process. As of 2013, the Commission estimated that there are more than 2,000 backlogged enforcement cases and that, based on the current rate of resolution, these would take 100 years to resolve. ${ }^{200}$

Two 2013 bills introduced in the California legislature would expand the enforcement authority of the Coastal Commission if adopted. AB 976 seeks to allow the Commission to directly levy fines and issue holds without resorting to the judiciary. ${ }^{201}$ Sarah Christie, the legislative director for the CCC, was quoted as saying the bill would give the Commission an enforcement tactic already used by "virtually every state regulatory agency and local government in California, including Malibu." ${ }^{202}$

The second bill, AB 203, would prohibit the Commission from "filing as complete" or acting upon an application for a coastal development permit for a property where there is an existing violation until the violation is resolved. ${ }^{203}$ A coalition of opponents raised concerns that the bill 
does not contain sufficient due process and would thus unfairly penalize an applicant based on the mere assertion by the Commission staff that a violation had occurred. However, the bill also provides that any unresolved dispute between the executive director and the applicant regarding the bill's implementation must be resolved by the Commission at a noticed public hearing. ${ }^{204}$

California's ability to execute a managed retreat from its eroding shores will require not only continued planning in state and local land use plans but also enforcement in both the executive and judiciary branches.

\section{LESSONS LEARNED AND RECOMMENDATIONS}

- Using a combination of set distances and erosion rates for setbacks can provide minimum standards for areas that lack historic erosion data while also acknowledging that erosion and sea level rise are unlikely to affect the coastline evenly and that approaches in one area may be inappropriate in another.

- Setbacks should be designed to account for acceleration of erosion and sea level rise due to climate change. This can be done through the use of a safety factor or by planning for routine updating of the setback distances. Updating setback numbers would, ideally, not require a state level legislative response, which could be slow and delay necessary changes.

- Setbacks should be established as soon as possible in order to set property owners' expectations for the value of their property. Minimum lot sizes and "savings" clauses can also be used to avoid takings challenges. However, when structures are built seaward of the setback line due to a variance or permit, it should be clear that the owner takes on the financial risk and that no public funding will be provided for future relief or rebuilding.

- Setbacks should be combined with a prohibition against coastal armoring in order to best implement a policy of managed retreat and protect the long-term health of beaches. See Chapter 3 on Prohibiting Armoring for more details.

- State and local governments must coordinate their planning efforts and regulations. The goals at both levels need to be consistent and complementary in order to be effective. See Chapter 1 on Coastal Management Planning for further discussion.

- Provide an enforcement mechanism to ensure that setback provisions are complied with and conduct regular evaluations to determine if the setbacks have been effective. 


\section{FURTHER READING}

The California Coastal Commission's Legal Authority to Address Climate Change, CALIFORNIA COASTAL COMMISSION (last visited Aug. 16, 2013), http://www.coastal.ca.gov/climate/whyinvolved.html.

Memorandum from Mark Johnsson to California Coastal Commission (Jan. 16, 2003), available at http://www.coastal.ca.gov/W-11.5-2mm3.pdf. (Academic article authored by a Staff Geologist at the Coastal Commission discussing methodology for establishing bluff setbacks.)

Construction Setbacks, National Oceanic And Atmospheric Administration (Jul. 13, 2012), http://coastalmanagement.noaa.gov/initiatives/shoreline ppr setbacks.html.

Mark Randall \& Hendrik deBoer, Office of Legislative Research, Connecticut General Assembly, COASTLINE CONSTRUCTION RESTRICTIONS (2012), available at http://www.cga.ct.gov/2012/rpt/2012R-0046.htm.

David Slade, Putting the Public Trust Doctrine to Work (2d ed. 1990). 


\title{
ROLLING EASEMENTS
}

Rolling easement is a term sometimes used to refer to any public policy that protects lands in the public trust as the sea level "rolls" inland. ${ }^{205}$ Setbacks, conservation easements, prohibitions on coastal armoring, and building restrictions can all be written using coastal markers (such as vegetation lines or mean high water lines) that move with the sea level and therefore recognize a rolling nature to the public trust lands.

In this chapter, however, the term rolling easement is used more specifically as an easement that grants the public access to a portion of the dry beach on a private property owner's land and that rolls inland with the rising sea.

\section{Texas Open Beaches Act}

Texas is traditionally the only state recognized as having enacted a policy of rolling easements. This is a significant issue in Texas, which has had one of the highest erosion rates in the nation since 1983, losing five to ten feet of beach every year. ${ }^{206}$ Texas implements its rolling easement through the Texas Open Beaches Act (TOBA) of $1959,{ }^{207}$ which defines a public beach as:

\begin{abstract}
[A]ny beach area, whether publicly or privately owned, extending from the line of mean low tide to the line of vegetation bordering on the Gulf of Mexico to which the public has acquired a right of use or easement to or over the area by prescription, dedication, presumption, or has retained a right by virtue of continuous right of the public since time immemorial, as recognized in law and custom. $^{208}$
\end{abstract}

The Act also explicitly affirms the right of the public to access the entire public beach, including any privately owned lands seaward of the vegetation line. ${ }^{209}$ The Commissioner of the Texas General Land Office (GLO) is authorized to enforce the TOBA and, in order to provide public access, is authorized to prohibit or remove any "obstruction, barrier, or restraint that will interfere with the free and unrestricted right of the public." 210 This means the Commissioner has the authority to restrict not only seawalls and coastal armoring but also housing and other structures that are constructed or that end up seaward of the mean vegetation line due to beach erosion.

\section{$\underline{\text { Providing Notice \& Assistance }}$}

Recognizing the potential impact for landowners, the TOBA also includes a disclosure provision that requires sales of property along the coast to include specific language regarding the risks of owning coastal property in the contract (see inset). ${ }^{211}$ Texas further assists property owners (and mitigates taking litigation) by providing a $\$ 50,000$ payment to homeowners to assist with relocation expenses. ${ }^{212}$ 


\section{Texas Open Beaches Act — Disclosure Requirement — NAT. RES. § 61.025.}

[Sales] must include in any executory contract for conveyance the following statement:

The real property described in this contract is located seaward of the Gulf Intracoastal Waterway to its southernmost point and then seaward of the longitudinal line also known as 97 degrees, 12', 19" which runs southerly to the international boundary from the intersection of the centerline of the Gulf Intracoastal Waterway and the Brownsville Ship Channel. If the property is in close proximity to a beach fronting the Gulf of Mexico, the purchaser is hereby advised that the public has acquired a right of use or easement to or over the area of any public beach by prescription, dedication, or presumption, or has retained a right by virtue of continuous right in the public since time immemorial, as recognized in law and custom.

The extreme seaward boundary of natural vegetation that spreads continuously inland customarily marks the landward boundary of the public easement. If there is no clearly marked natural vegetation line, the landward boundary of the easement is as provided by Sections 61.016 and 61.017, Natural Resources Code.

State law prohibits any obstruction, barrier, restraint, or interference with the use of the public easement, including the placement of structures seaward of the landward boundary of the easement. STRUCTURES ERECTED SEAWARD OF THE VEGETATION LINE (OR OTHER APPLICABLE EASEMENT BOUNDARY) OR THAT BECOME SEAWARD OF THE VEGETATION LINE AS A RESULT OF NATURAL PROCESSES SUCH AS SHORELINE EROSION ARE SUBJECT TO A LAWSUIT BY THE STATE OF TEXAS TO REMOVE THE STRUCTURES.

The purchaser is hereby notified that the purchaser should:

(1) determine the rate of shoreline erosion in the vicinity of the real property;

and

(2) seek the advice of an attorney or other qualified person before executing this contract or instrument of conveyance as to the relevance of these statutes and facts to the value of the property the purchaser is hereby purchasing or contracting to purchase.

\section{Litigation Experience}

When Hurricane Alicia struck Texas August 18, 1983, it moved the public beach easement nearly 13 feet inland (150 inches). As a result, several homes became located on the public beach, so their repair or reconstruction was prohibited. ${ }^{213}$ In Matcha v. Mattox, (1986), the TOBA was challenged as a taking and was upheld because the beach easement had "migrated onto their property." ${ }^{214}$ As of 2003 , Texas allowed homeowners to seek a moratorium against removal for two years to see if the beach would return to its pre-storm distance, thereby placing the home back on solely private property. ${ }^{215}$ 
When Hurricane Ike hit in 2008 and destroyed many coastal properties, the General Land Office first established a temporary line 4.5 feet above sea level for interim permitting and rebuilding decisions and then later moved back to the vegetation line for establishing the public beach boundary. ${ }^{216}$ Then-Texas General Land Commissioner Jerry Patterson explained the delay at the time by saying, "You want to have at least a complete all four seasons and find out what Mother Nature is actually going to do until she finishes what she's going to do." ${ }^{217}$ Although reasonable from an enforcement perspective, it left homeowners uncertain whether or not to invest in repairs.

Thirty-seven homes along Pedestrian Beach, near Surfside, Texas, were denied permits to repair their septic systems and had their access to water shut off. ${ }^{218}$ The houses were found to significantly block public access to the beach and were therefore ordered to be removed. Property owners sued for compensation, claiming this was a government taking of their property, but the TOBA was upheld by the Texas Court of Appeals in Brennan v. State. ${ }^{219}$

However, it is important to note that the court in Brennan held that TOBA was not a taking because the Act itself had not established the easement. Rather, the act was an enforcement mechanism for a public easement that had been established through custom and historic dedication. $^{220}$

\section{Severance v. Patterson - Avulsion v. Accretion}

In 2011, the Texas Supreme Court issued a decision in Severance v. Patterson that makes the future of rolling easements uncertain. ${ }^{* * *}$ In Severance, for the first time in Texas law, the Court distinguished between accretion, in which slow-onset beach erosion moves the beach, and avulsion, in which a storm or other catastrophic event suddenly moves the beach, and found that Texas' rolling easement does not apply to avulsion. Furthermore, the Court held that unless a public easement was expressly included in the initial land grant, the state cannot rely on custom alone to secure public access. ${ }^{221}$ The court looked at TOBA and decided that the Act did not explicitly recognize a "rolling" easement. This creates significant uncertainty about the ability of the General Land Office to remove structures from eroding beaches following storms and to maintain public access. ${ }^{222}$

\footnotetext{
${ }^{* * *}$ Severance v. Patterson, 345 S.W.3d 49 (Tex. 2011).
} 


\section{LESSONS LEARNED AND RECOMMENDATIONS}

- A state wishing to implement a rolling easement should explicitly create one in state legislation. The initial creation of the easement may be considered a taking and require compensation, either monetary or through an offset. ${ }^{++t}$ However, this compensation will be far less substantial than that required to purchase a home outright, and it will also secure public beach access.

- A rolling easement could also be acquired through the use of exactions. Private owners seeking to build or expand coastal properties could be required to allow a public easement as an offset to the negative externalities of coastal development. (See Chapter 3 on Prohibiting Coastal Armoring for a further discussion on exactions.)

- Rolling easements must be combined with policies to prevent coastal armoring in order to be effective. Coastal armoring would both destroy the beach (thereby negating the public access purpose of the easement) and prevent the beach from rolling inland.

- Sales of coastal property should include a disclosure requirement that informs prospective purchasers of the risks they face. This may not prevent takings litigation, but it will promote awareness of the costs of coastal living, which will assist in the implementation of further policies.

\section{FURTHER READING}

James Titus, Rolling Easements Primer (EPA Climate Ready Estuaries, 2011), available at www.water.epa.gov/type/oceb/cre/upload/rollingeasementsprimer.pdf.

Meg Caldwell \& Craig Holt Segall, No Day at the Beach: Sea Level Rise, Ecosystem Loss, and Public Access along the California Coast, 34 ECOLOgy LAW QUARTERLY 533 (2007).

Public Use: Texas Works to Protect Rights and Beaches, National Oceanic AND AtMOSPHeric Administration CoAstal Services Center (last visited Aug. 16, 2013), http://www.csc.noaa.gov/magazine/2007/06/article2.html.

Severance v. Patterson - Frequently Asked Questions, TeXAS General LAND OfFICE (last visited Aug. 16, 2013), http://www.glo.texas.gov/what-we-do/caring-for-the-coast/ documents/openbeaches/faq-open-beaches.pdf.

\footnotetext{
${ }^{+++}$A home with a rolling easement would depreciate in value, but if the loss is expected to occur 100 years from today, it would only reduce the current property value by I to 5 percent, which could be compensated or offset by other permit considerations (Titus, 1998).
} 


\section{REFERENCES}

${ }^{144}$ First codified by the Roman Emperor Justinianaround 500 AD as part of Roman civil law, then adopted by British common law and finally by the thirteen original colonies. NEW JERSEY DEPARTMENT OF ENVIRONMENTAL PROTECTION, Public Access in New Jersey: The Public Trust Doctrine and Practical Steps to Enhance Public Access 9-10 (2005), available at www.state.nj.us/dep/cmp/access/public_access_handbook.pdf.

145 See id.; David Slade, Putting the Public Trust Doctrine to Work (2d ed. 1990); RALPH W. JOHNSON ET AL., SHORELANDS and Coastal Zone management Program, Washington Department of Ecology, the Public Trust Doctrine and Coastal ZONE MANAGEMENT IN WASHINGTON STATE (1991), available at https://fortress.wa.gov/ecy/publications/publications/93054.pdf.

${ }^{146} 43$ U.S.C. § 1301-1315 (2013).

${ }^{147}$ Borax Consolidated, Ltd. v. City of Los Angeles, 296 U.S. 10 (1935) specified the mean high tide line as the shoreline boundary. Following the ruling most states chose to adopt this federal standard. See also Meg Caldwell \& Craig Holt Segall, No Day at the Beach: Sea Level Rise, Ecosystem Loss, and Public Access along the California Coast, 34 ECOlogy LaW QuARTERLY 533 (2007).

${ }^{148}$ Massachusetts, Maine, Delaware, and Virginia extend private title to mean low water. Generally, this is a result of colonial ordinances intended to encourage wharf development. See Shively v. Bowlby, 152 U.S. 1, 18-26 (1984) (reviewing the extent of private title and public trust in the colonies); Heather J. Wilson, The Public Trust Doctrine in Massachusetts Land Law, 11 Boston College EnVIRonmental AfFaiRs LAW ReVIeW 839 (1984).

${ }^{149}$ Texas Open Beaches Act, TeX. NAT. Res. Code ANN. § 61 (2010); Matthews v. Bay Head Improvement Ass'n, 471 A.2d 355 (N.J. 1984) (holding that the public trust right to bathe is meaningless without the accompanying right to be on the dry sand beach).

${ }^{150}$ For example, Florida's Beach and Shore Preservation Act, FLA. STAT. $§ 161.053$ (2010) requires that an erosion control line be established prior to nourishment activities and designates this line as the boundary between public and private property.

${ }^{151}$ Walton Cnty. v. Stop the Beach Renourishment Inc., 998 So.2d 1102 (Fla. 2008). Similarly, in North Carolina, all nourishment activities undertaken with public funding inhere title in the newly created beach to the state. 182 N.C. Gen. Stat. § 146-6(f) (2010). See also Cal. Civ. Code § 1014 (2010); Tex. Nat. Res. Code § 61 (2010).

152 Stop the Beach Renourishment, Inc. v. Florida Department of Environmental Protection, et al. 560 U.S. 130 S. Ct. 2592, 177 L. Ed. 2d 184 (2010).

${ }^{153}$ Gorieb v. Fox, 274 U.S. 603 (1927).

154 J.F. O'Connell, Shoreline Armoring Impacts and Management Along the Shores of Massachusetts and Kauai,

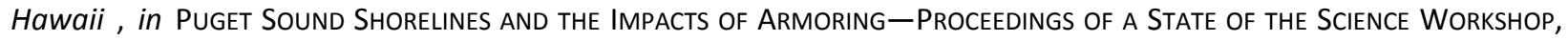
MAY 2009 65, 65 (H. Shipman et al. eds., 2010).

155 Construction Setbacks, NATIONAL OCEANIC AND ATMOSPHERIC AdMINISTRATION (Jul. 13, 2012), http://coastalmanagement.noaa.gov/initiatives/shoreline_ppr_setbacks.html.

${ }^{156} / d$.

157 15A N.C. AdMIN. CODE 7B .0306 (2009).

158 Id.; see also Construction Setbacks, NATIONAL OCEANIC AND AtMOSPHeric AdMinistration (Jul. 13, 2012), http://coastalmanagement.noaa.gov/initiatives/shoreline_ppr_setbacks.html.

${ }^{159}$ The average erosion rate is defined in 15A N.C. ADMIN. CODE 7H 0304 (2009). The average erosion rates of various North Carolina beaches and information on how those rates were calculated can be found in NORTH Carolina Department of Environment and Natural Resources - Division of Coastal Management, 2011 Long-Term 


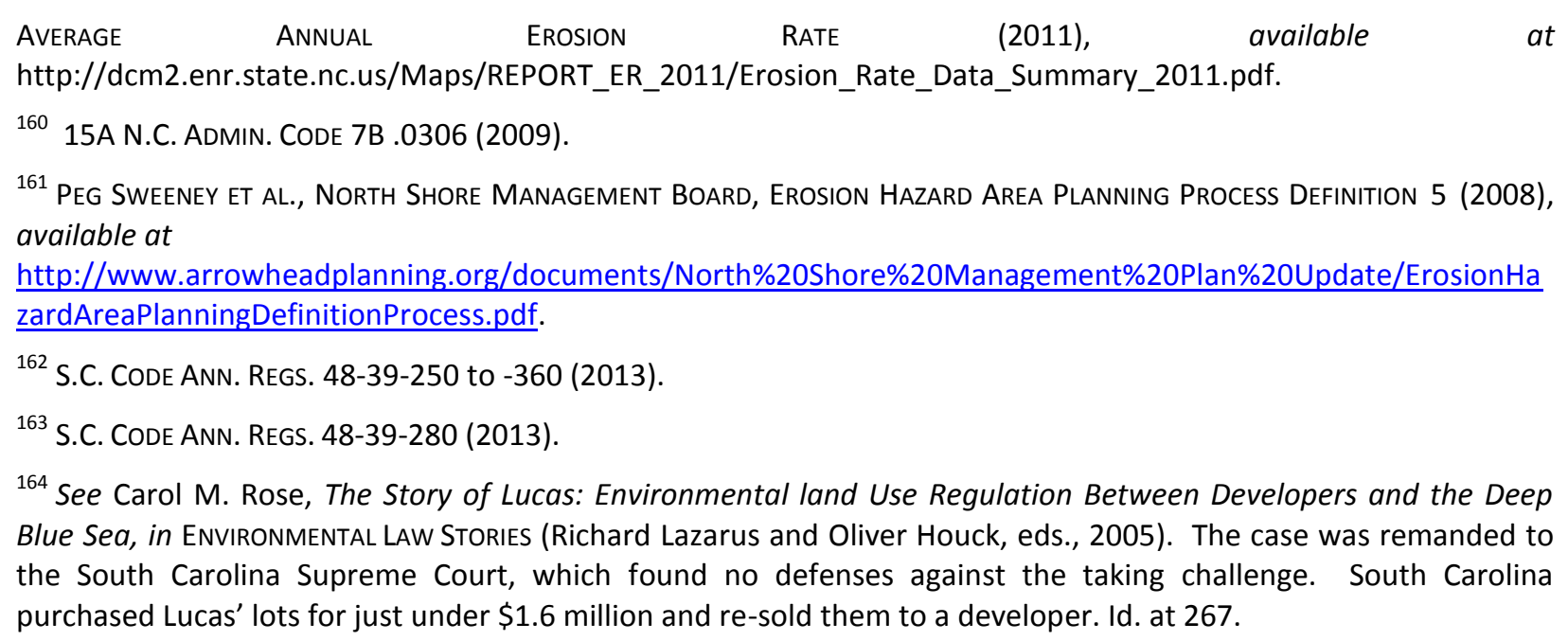
http://www.sfbayjv.org/tools/SetbackLaw.pdf. See also Del Oro Hills v. City of Oceanside, 31 Cal. App. 4th 1060, 1076 (1995) ("[A]n ordinance is safe from a facial challenge if it preserves, through a permit procedure or otherwise, some economically viable use of the property.").

${ }^{166}$ MINN. R. 6120.3300 (2013).

${ }^{167}$ Fla. AdMin. Code AnN. R. 62b-33.002 (2013).

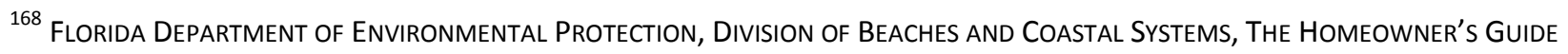
to the Coastal Construction Control line Program (Section 161.053, Florida Statutes) (2006), available at www.dep.state.fl.us/beaches/publications/pdf/propownr.pdf.

${ }^{169}$ SANDY WARD \& CATHERINe MaIN, NATIONAL OCEANIC AND ATMOSPHERIC AdMINISTRATION, ReduCING THE IMPACTS OF COASTAL HAZARDS 12 (1998), available at http://oceanservice.noaa.gov/websites/retiredsites/sotc pdf/RTT.PDF.

170 Id. at 13.

171 Florida Department of EnVIRonmental Protection, Division of BeAches And CoAstal Systems, The Homeowner's Guide to the Coastal Construction Control line Program (Section 161.053, Florida Statutes) 3 (2006), available at www.dep.state.fl.us/beaches/publications/pdf/propownr.pdf.

172 Id. at 7.

${ }^{173}$ Hawaii Beaches Eroding: Maui, Kauai, Oahu Tourist Sites Disappearing, Huffington POST, May 8, 2012, http://www.huffingtonpost.com/2012/05/08/hawaii-beaches-eroding n 1499870.html.

${ }^{174}$ S.G. Genz et al., The Predictive Accuracy of Shoreline Change Rate Methods and Alongshore Beach Variation on Maui, Hawaii, Journal of COASTAL ReSEARCH, Jan. 2007, at 87, 87.

${ }^{175}$ Press Release, United States Geological Survey, 70 Percent of Beaches Eroding on Hawaiian Islands Kauai, Oahu, and Maui (May 7, 2012), http://www.usgs.gov/newsroom/article.asp?ID=3199. See also C. Fletcher, Kauai Shoreline Study Erosion Maps, School of OCEAN AND EARTH SCIENCE AND TECHNOLOGY, UNIVERSITY OF HAWAI`I AT MĀNOA (2009), http://www.soest.hawaii.edu/coasts/kauaicounty/KCounty.html.

${ }^{176}$ KAUA'I COUNTY, HAW., ORDINANCE $863 \S 1$ (Jan. 25, 2008).

177 KAUA'I COUNTY, HAW., CODE $§ 8-27.3$ (2008).

178 HAW. REV. STAT. § 205A-2(c)(9)(B) (2013).

179 Hawall Department of Land and Natural Resources, Hawall Coastal ERosion Management Plan 20 (2000), available at http://hawaii.gov/dlnr/occl/documents-forms/policies-plans/coemap.pdf. 
${ }^{180}$ HAW. REV. STAT. $§ 205 A-1$ (2013). "The upper reaches of the wash of the waves, other than storm or seismic waves, at high tide during the season of the year in which the highest wash of the waves occurs, usually evidenced by the edge of vegetation growth, or the upper limit of debris left by the wash of the waves." Id.

${ }^{181}$ See O'Connell, supra note 154 , at 68.

182 HaWAII COASTAL EROSION MANAgEMENT PLAN, supra note 179 , at 18.

${ }^{183}$ C. Fletcher et al., Beach Loss Along Armored Shoreline on Oahu, Hawaiian Islands, JOURNAL OF COASTAL RESEARCH, Winter 1997, at 209.

${ }^{184}$ Bradley M. Romine \& Charles H Fletcher, Armoring on Eroding Coasts Leads to Beach Narrowing and Loss on Oahu, Hawaii, in Pitfalls of Shoreline Stabilization: Selected Case Studies 141, 148 (J.A.G. Cooper \& Orrin H. Pilkey eds., 2012).

${ }^{185}$ The other two coastal management agencies are the San Francisco Bay Conservation and Development Commission and the California Coastal Conservancy.

${ }^{186}$ CAL. Pub. RES. CODE $\S \S 30000-30900$ (West 2013).

${ }^{187}$ Local Coastal Programs, CALIFORNIA COASTAL COMMISSION (2012), http://www.coastal.ca.gov/lcps.html.

${ }^{188}$ See, e.g., City of Pismo Beach Request, http://documents.coastal.ca.gov/reports/2013/1/Th20a-1-2013.pdf ("Thus, as modified, the amendment ensures internal consistency among LCP policies, and is also consistency with the requirement that bluff top setbacks minimize risks from coastal hazards, consistent with Coastal Act Section 30253.").

189 See, e.g., id. (requiring a twenty-five foot setback); see also CALIFORNIA COASTAL COMMISSION, STAFF Recommendation on City of NeWPort BeACH LAND Use PLAN AMENDMENT 1-04 (2005), available at http://www.coastal.ca.gov/lb/Th8d-10-2005.pdf.

${ }^{190} / d$.

191 County of Mendocino, California, Mendocino General Plan: CoAstal Element (1991), available at http://www.co.mendocino.ca.us/planning/plans/planCoastalTOC.htm.

192 Marin County Planning Commission, marin County local Coastal Program land Use Plan \& Development Code: PROPOSED AMENDMENTS (2012), available at http://www.co.marin.ca.us/depts/CD/main/lcp/LCP-index.html.

193 Id. § C-EH-5, at 33.

194 MARIN COUNTY, CAL., CODE $§ 22.64 .060$ (B) (2012).

195 Marin County Planning Commission, marin County local Coastal Program land Use Plan \& Development Code: PROPOSED AMENDMENTS \& C-EH-5, AT 33 (2012), available at http://www.co.marin.ca.us/depts/CD/main/lcp/LCPindex.html.

${ }^{196}$ State of California SeA-LeVel Rise Guidance Document (California Ocean Protection Council, March 2013), http://www.opc.ca.gov/webmaster/ftp/pdf/docs/2013_SLR_Guidance_Update_FINAL1.pdf. The California Ocean Protection Council was established under the 2004 California Ocean Protection Act and directed to issue SLR guidance by Governor Schwarzenegger's Executive Order S-13-08.

197 Enforcement Program Overview, CALIFORNIA COASTAL COMMISSION (last visited Aug. 16, 2013), http://www.coastal.ca.gov/enforcement/enforcement_program.pdf.

198 See CAL. PUB. RES. CODE §§ 30810-30821 (West 2013).

199 Id.

${ }^{200}$ Committee on natural Resources, California State Assembly, Bill Analysis: AB-203 Coastal Resources: Coastal Development Permits: Penalties 3 (2013), available at http://www.leginfo.ca.gov/pub/13-14/bill/asm/ab 02010250/ab 203 cfa 20130328155218 asm comm.html. 
${ }^{201}$ Melissa Caskey, Coastal Commission Seeks Broad Authority to Fine Violators, MALIBU TIMES, Apr. 23, 2013, http://www.malibutimes.com/news/article 6275b552-acad-11e2-855f-0019bb2963f4.html.

202 Id.

203 A.B. 203, State Assemb., 2013-2014 Sess. (Cal. 2013), available at http://www.leginfo.ca.gov/pub/1314/bill/asm/ab_0201-0250/ab_203_bill_20130130_introduced.html ("The bill would prohibit the commission, with exceptions, from filing as complete, or acting upon, an application for a coastal development permit for a project on property that is subject to an existing violation case for which a violation notification letter has been sent, or a cease and desist order, restoration order, or notice of violation has been issued or recorded until the violation has been resolved.").

${ }^{204}$ A.B. 203 is currently inactive. A.B. 976 is currently in the Standing Committee on Rules for Assignment.

205 James Titus, Rising Seas, Coastal Erosion, and the Takings Clause: how to Save Wetlands and Beaches Without Hurting Property Owners, 57 Maryland Law Review 1279, 1316 (1998). See also Meg Caldwell \& Craig Holt Segall, No Day at the Beach: Sea Level Rise, Ecosystem Loss, and Public Access Along the California Coast, 34 Ecology LAW QUARTERLY 533 (2007).

${ }^{206}$ Public Use: Texas Works to Protect Rights and Beaches, NATIONAL OCEANIC AND ATMOSPHERIC AdMINISTRATION COASTAL SERVICES CENTER (last visited Aug. 16, 2013), http://www.csc.noaa.gov/magazine/2007/06/article2.html.

${ }^{207}$ TOBA was the result of the codification of the court's decision in Luttes v. State, 324 S.W.2d 167 (Tex., 1958), which decided that the land is 'public' from the mean high tide line seaward.

${ }^{208}$ Tex. NAT. Res. CODE ANN. § 61.001 (West 2010).

${ }^{209}$ Id. $§ 61.011$.

${ }^{210}$ Id. $\S 61.018$.

${ }^{211}$ Id. $\S 61.025$.

${ }^{212}$ Public Use: Texas Works to Protect Rights and Beaches, NATIONAL OCEANIC AND ATMOSPHERIC ADMINISTRATION COASTAL SERVICES CenTER (last visited Aug. 16, 2013), http://www.csc.noaa.gov/magazine/2007/06/article2.html.

${ }^{213}$ Matcha v. Mattox, 711 S.W.2d 95 (Tex. 1986); see also Hurricane Alicia, 1983, USA TodAY, Sept. 21, 2005, http://usatoday30.usatoday.com/weather/hurricane/history/walicia.htm.

${ }^{214}$ Matcha v. Mattox, 711 S.W.2d 95 (Tex. 1986).

$215 \mathrm{Jim}$ Hiney, Taking a Stand in the Sand, TEXAS SHORES, Winter 2004, at 2, 19.

216 FAQ: Hurricane Ike and the Texas Open Beaches Act, TEXAS GENERAL LAND OfFICE (last visited Aug. 16, 2013), http://www.glo.texas.gov/texas-beach-access/pdf/news/FAQ 082109.pdf.

217 See Michael Graczyk \& Cain Burdeau, Some Ike Victims May Not be Allowed to Rebuild, USA ToDAY, Sept. 18, 2008, http://www.huffingtonpost.com/2012/05/08/hawaii-beaches-eroding n 1499870.html.

${ }^{218}$ Brannan v. State, 365 S.W.3d 1, 6 (2013).

${ }^{219}$ Id.

${ }^{220}$ Id. at 27. See also Michael McCauley, Texas Court Upholds "Rolling Easements" on Beachfront Property, 30:1 WATER LOG 11 (2010), available at http://nsgl.gso.uri.edu/masgc/masgcn1003b.pdf.

${ }^{221}$ Severance v. Patterson, 370 S.W.3d 705 (Tex. 2012).

${ }^{222}$ Severance v. Patterson - Frequently Asked Questions, TeXAS General LAND OffiCE (last visited Aug. 16, 2013), http://www.glo.texas.gov/what-we-do/caring-for-the-coast/documents/open-beaches/faq-open-beaches.pdf. 
Columbia Center for Climate Change Law

$62 \mid \mathrm{P}$ a g e 


\section{ChAPTER 3}

\section{Preventing Private Coastal Armoring}

Coastal armoring is one of the most prevalent structural solutions to the risks posed by erosion and sea level rise. The term 'coastal armoring' encompasses a number of practices that are generally divided into soft and hard approaches. Soft armoring refers to the use of organic materials to strengthen and protect the shoreline. Because soft armor uses living materials, it can imitate natural systems, interact with the local ecosystem, and adapt to changes in the environment. ${ }^{223}$ Hard armoring refers instead to structures like retaining walls and bulkheads that physically block wave and current action from reaching the vulnerable shoreline. ${ }^{224}$ Hard armoring has traditionally been employed by private owners and local governments who want to preserve coastal development and its associated economic benefits.

This chapter will focus on methods to prevent the use of hard armoring by private landowners. State legislatures and executive agencies can limit the ability of private landowners to install hard armoring solutions by enacting strict requirements for building permits or by simply banning the use of hard armoring. Preventing hard armoring will allow sea level rise, erosion, and other natural processes to take their course without impediment and the resulting changes to the shoreline will encourage landowners to build further inland. This can be particularly effective in promoting managed retreat when coupled with a setback or rolling easement (see Chapter 2 ). Preventing armoring will allow the beach to recede landward, and the setback or rolling easement will require the relocation or removal of structures that become located too close to the coast.

A number of states, including Maine, Massachusetts, North Carolina, Oregon, Rhode Island, South Carolina, and Texas, have banned shoreline armoring or imposed significant restrictions. There are three general approaches to controlling hard armoring: enact a statute that prohibits it entirely, require a rigorous permitting process, or obtain exactions from coastal landowners.

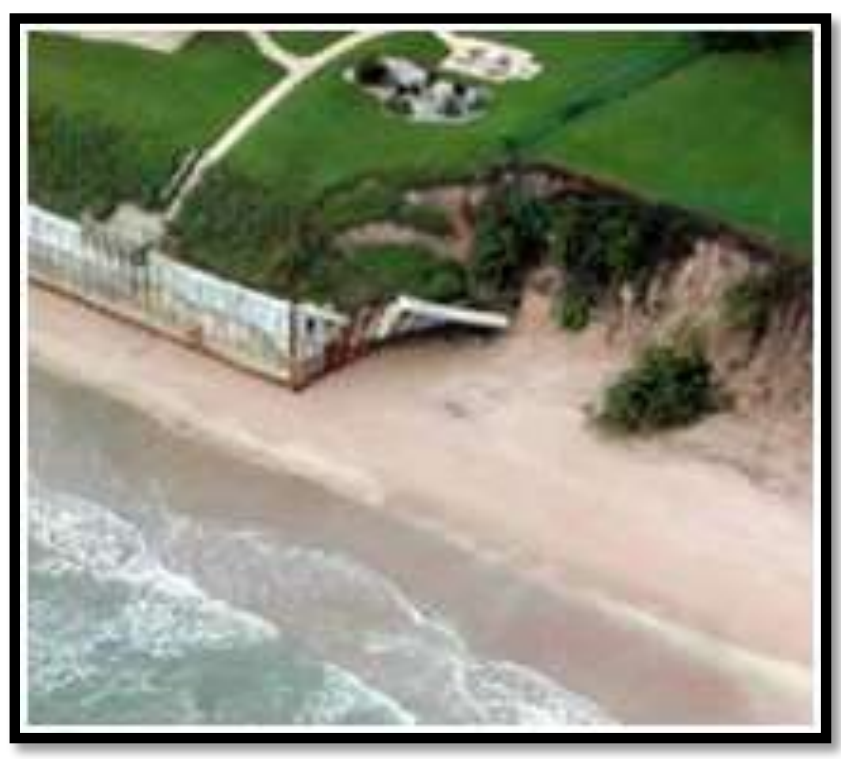

States generally avoid a strict prohibition, but examples of permitting, restrictions and exactions will be discussed in greater detail below.

The effect of a bulkhead on adjacent property.

Photo: US Fish and Wild life Service. 


\begin{tabular}{|c|c|}
\hline Common Hard Armoring Structures & Example \\
\hline \multicolumn{2}{|l|}{$\begin{array}{c}\text { Seawalls: } \\
\text { Shore-parallel vertical structure, generally } \\
\text { concrete, wood, or steel, that primarily protects } \\
\text { the shore against the force of waves. }\end{array}$} \\
\hline $\begin{array}{l}\text { Bulkheads and Retaining Walls } \\
\text { Shore-parallel vertical structure, generally } \\
\text { concrete, wood, or steel, that prevents erosion by } \\
\text { separating land and water and retaining soil.. }\end{array}$ & 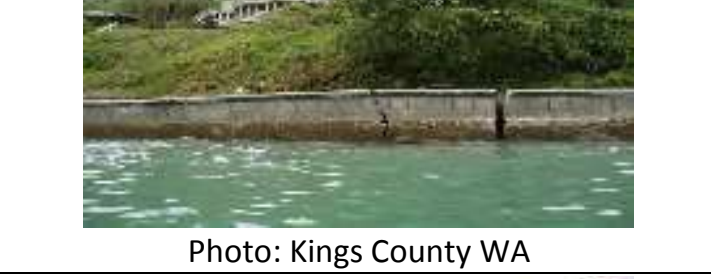 \\
\hline $\begin{array}{l}\text { Revetment: } \\
\text { A slope of stone or other material built to protect } \\
\text { an embankment or other coastal structure by } \\
\text { absorbing the energy of incoming waves. } \\
\text { Revetments built out of smaller rocks are known } \\
\text { as riprap (a term that also applies to the stone } \\
\text { used to build the riprap). }\end{array}$ & Photo: Federal Highway Administration \\
\hline $\begin{array}{l}\text { Groin: } \\
\text { A narrow, shore-perpendicular structure built to } \\
\text { interrupt water flow, reduce longshore currents, } \\
\text { and limit the movement of sediment. }\end{array}$ & $\begin{array}{l}\text { Photo: NC Department Environment and Natural } \\
\text { Resources }\end{array}$ \\
\hline $\begin{array}{l}\text { Breakwater: } \\
\text { An offshore, beach-parallel structure usually } \\
\text { consisting of large (several ton) rocks designed to } \\
\text { reduce intensity of wave action. }\end{array}$ & Photo: Seattle Department of Transportation \\
\hline $\begin{array}{l}\text { Levee: } \\
\text { A raised embankment, usually earthen, parallel to } \\
\text { the water, designed to contain or divert the flow } \\
\text { of water. }\end{array}$ & 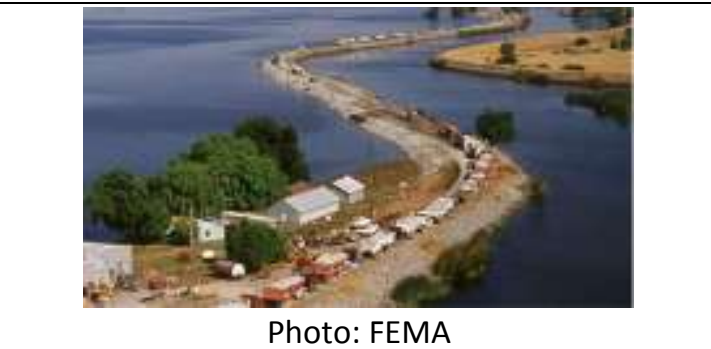 \\
\hline
\end{tabular}




\section{Costs and Harms of Hard Armoring}

Hard armoring has significant costs and limitations. In additional to the financial cost to build and maintain armoring structures, hard armoring can damage property, harm ecosystems, destroy public beach access, and encourage development in risky areas.

Hard armoring structures can be expensive to build: millions of federal, state, and private dollars have been expended annual on shore armoring, which can cost anywhere from $\$ 500$ to $\$ \mathbf{\$} 7,600$ per linear foot of coast. ${ }^{225}$ A proposal to install harborwide barriers to protect New York City could cost $\$ 25$ billion just to build and take two to three decades to complete. ${ }^{226}$ As the U.S. Army Corps of Engineers notes, even choosing a 'low cost' hard armoring solution "does not necessarily mean they are 'cheap'." 227 In addition to the initial construction costs, hard armoring structures can also be expensive to maintain, ${ }^{228}$ and many

\section{Costs of Armoring}

In California, between 1985 and 1990, 45 miles of armoring was installed at an average cost of $\$ 1,500$ per foot for a total of $\$ 60$ million per year. By 1998, coastal armoring had been installed to protect $12 \%$ (roughly $1 / 8$ ) of the coastline statewide and California residents were paying more than $\mathbf{\$} \mathbf{7 5}$ million per year. have a finite lifespan and will need to be replaced once or even twice before the end of the century. ${ }^{229}$ Rising sea levels due to climate change will increase the chance that walls will need to be raised or rebuilt higher at additional expense.

In addition to the construction and maintenance costs, hard armoring structures have social and environmental costs. The presence of a hard structure on the shore disrupts the natural interaction of sand and waves. Indeed, this is its purpose: to prevent erosion due to this interaction. However, hard structures can have unintended consequences that actually accelerate beach erosion in front of the structure, cause additional erosion on neighboring properties, narrow the beach (thereby restricting public access to the beach), and harm coastal ecosystems. ${ }^{230}$

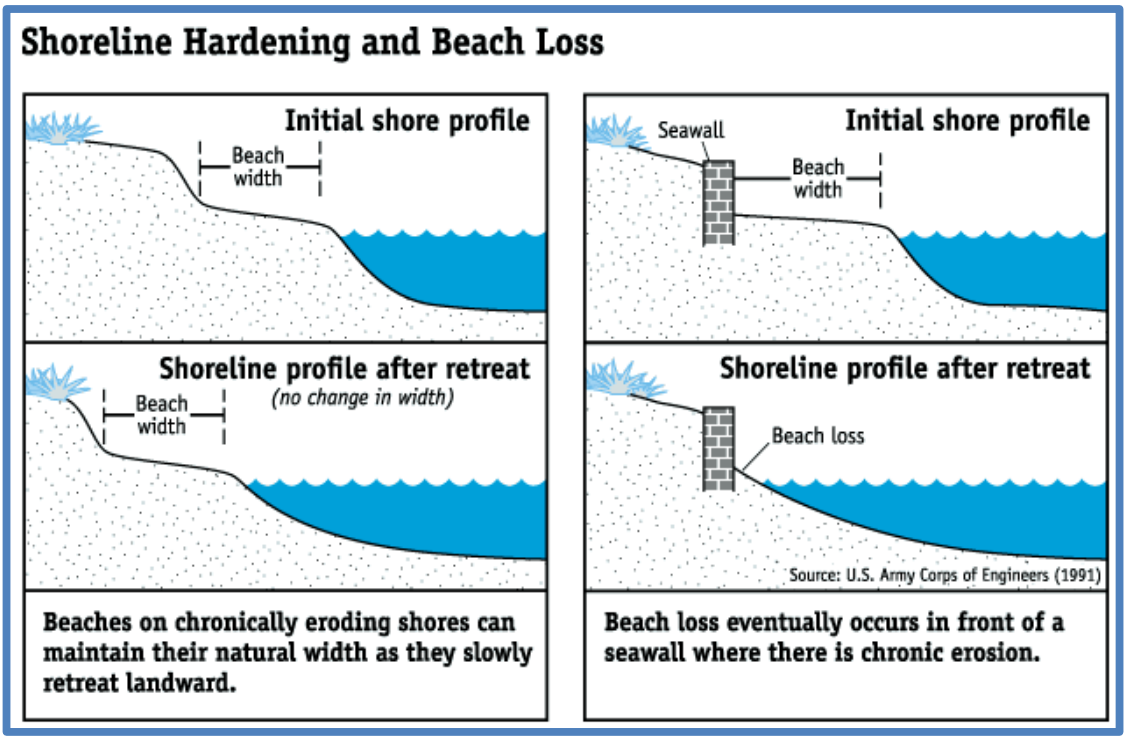

On eroding beaches without armoring structures, the beach will naturally migrate inland while often retaining its original width. But the presence of an armoring structure prevents this migration and results in the narrowing of the original beach and, eventually, the loss of the beach entirely (see image at left). ${ }^{231}$ 
Seawalls, bulkheads, and breakwaters can redirect wave action towards neighboring shores, causing damage to neighboring properties (see image below). And longshore currents (parallel to the shore) can cause "flanking" erosion along the edges of the armoring, ${ }^{232}$ damaging nearby properties and in some cases causing instability of the seawall. ${ }^{233}$ Some structures may increase the energy of waves in front of and alongside the structure, thereby accelerating the very beach erosion they were meant to prevent. $^{234}$ Vertical seawalls and bulkheads can cause vertical erosion in front of the structure, called scour, as illustrated below. By changing

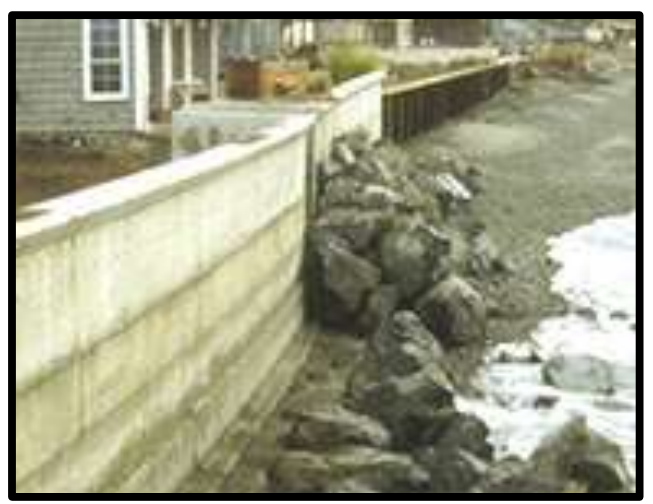

Narrowed beach in front of a bulkhead. Photo: WA Department of Ecology. the wave and current dynamics and preventing beach migration, barriers can also cause additional flooding in nearby areas that are unprotected, making those communities more vulnerable than they would have been before the installation of the armoring structures. ${ }^{235}$ These harmful effects can extend far beyond the immediate reach of the armoring. ${ }^{236}$

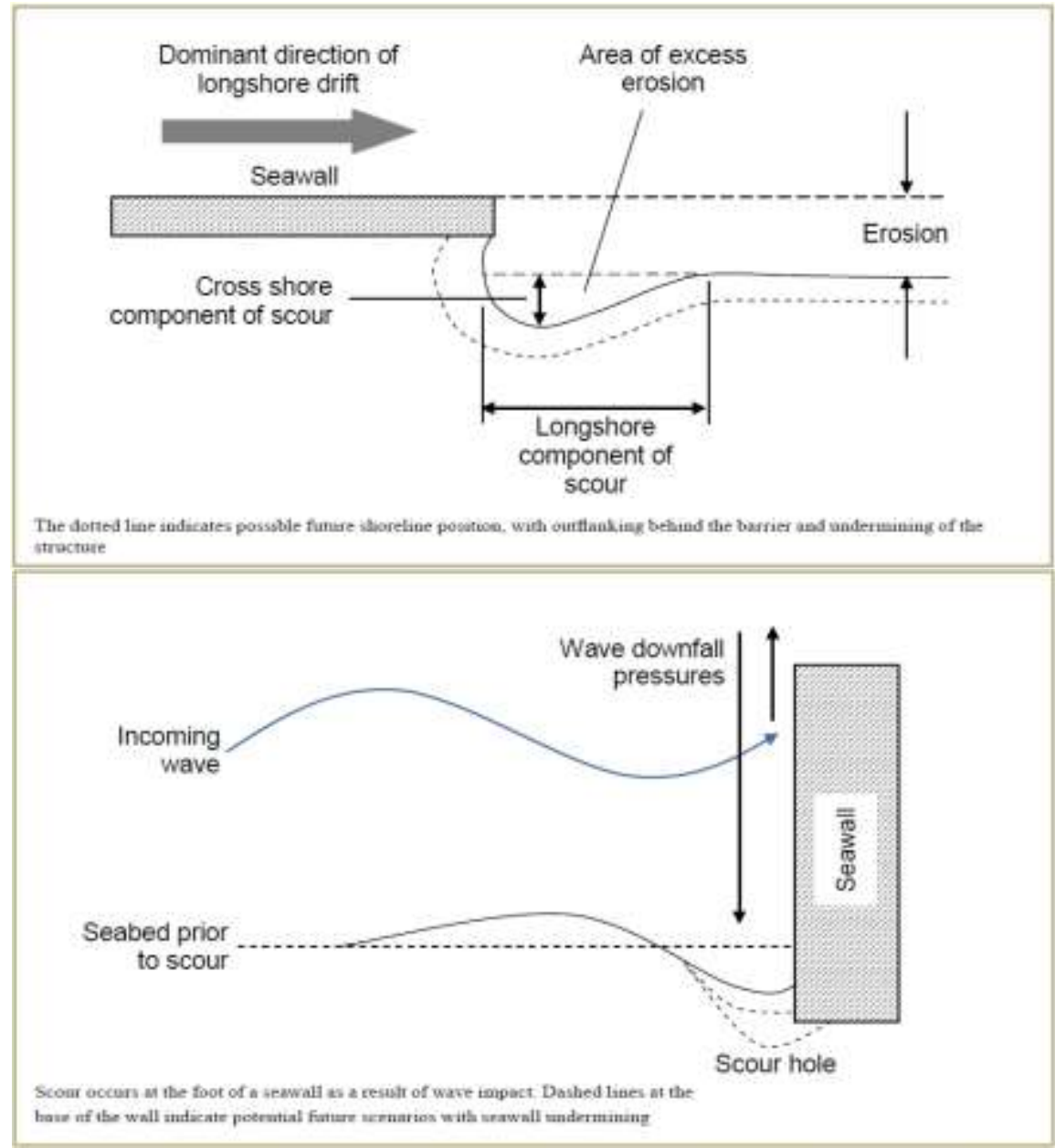

Source: UNEP, Technologies for Climate Change Adaptation: Coastal Erosion and Flooding (2010). 


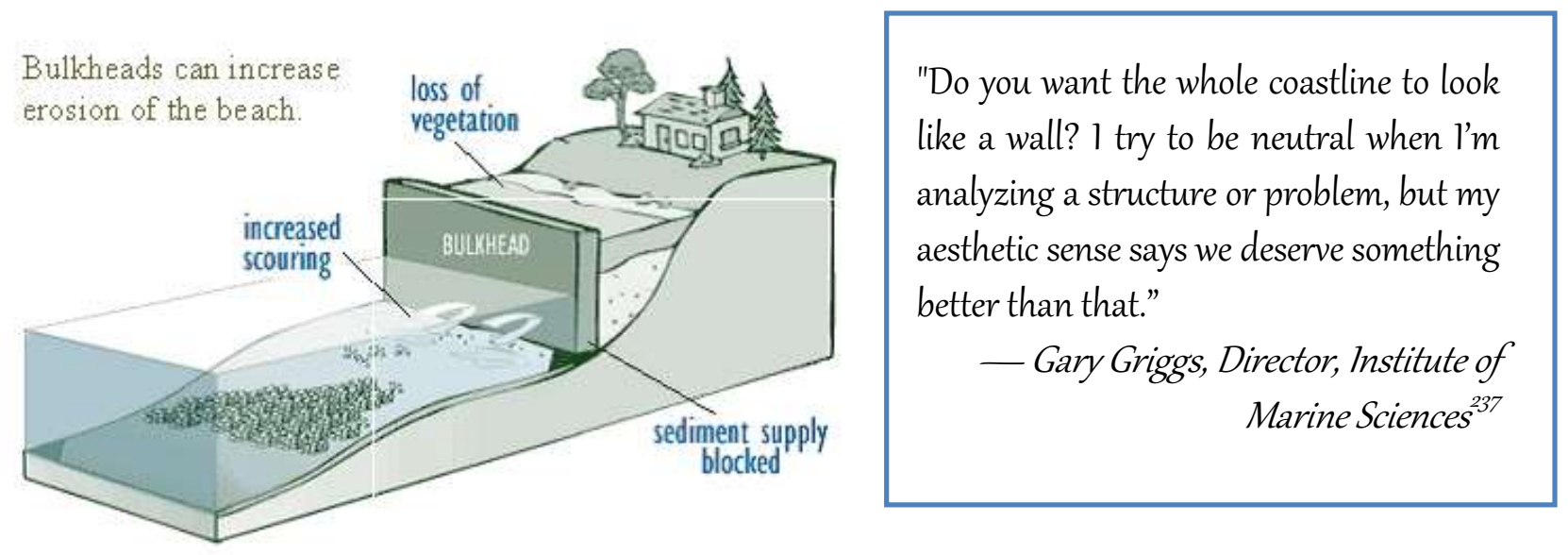

Effect of bulkhead on surrounding land. Photo: WA Department of Ecology.

On the environmental side, coastal armoring disrupts coastal ecosystems by blocking natural sediment flows, displacing vegetation (construction often destroys local vegetation, which does not always recover), preventing driftwood accumulation, and upsetting the natural food web upon which the ecosystem depends. ${ }^{238}$

Coastal armoring can also increase risk to coastal communities. As described by the United Nations Internal Strategy for Disaster Reduction:

Protective works have a tendency to increase the level of development in floodprone areas, as the assumption is made that it is now safe to build and invest in areas that are protected. However, it must be recognized that at some point in the future the design event will likely be exceeded and catastrophic damages will result. ${ }^{239}$

Some communities believe they are protected by a seawall or bulkhead and therefore decline to spend additional funds on other protection measures (such as setbacks and building codes).

But, if the coastal armoring fails (as has happened in the past, in New Orleans ${ }^{240}$ and Japan ${ }^{241}$ most recently, and is possible in the future) the resulting damage to the community can be extreme. Policy makers should be careful to avoid this hazard by raising awareness on the risks of flooding and catastrophic failure and requiring redundancies in flood protections.

Failed Sea Wall in the 9th Ward of New Orleans. Photo National Park Service.

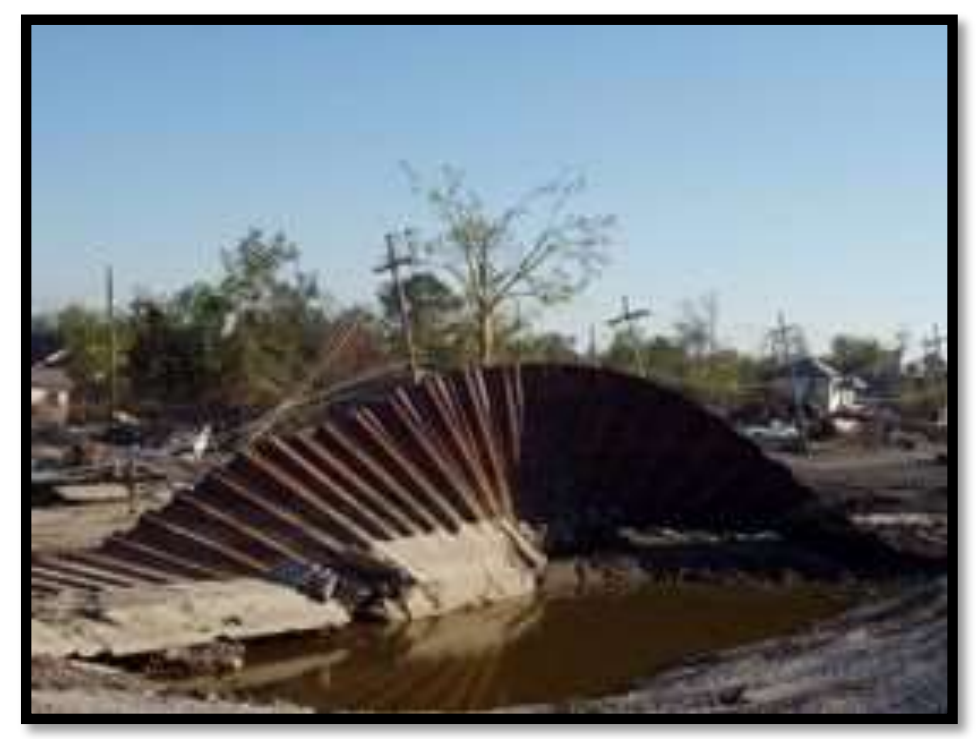




\section{A Note on the Common Enemy Doctrine}

The Common Enemy Doctrine is an old legal principle that considers waters to be a "common enemy" of landowners and therefore gives a landowner the right to repel or capture water without becoming liable for the adverse effects this might have on neighbors. ${ }^{242}$ Landowners seeking to build hard armoring structures have raised this doctrine as a defense against the damage their seawalls might cause to neighbors (see inset).

In recent years, there has been a shift toward replacing the common enemy doctrine with a reasonable use test, which holds landowners liable if their actions are unreasonable or result in unreasonable harm to neighboring lands. ${ }^{243}$ Roughly half the United States has adopted the reasonable use test. ${ }^{244}$ Some states use a modified common enemy doctrine that, in practice, often ends up resembling the reasonable use test. $^{245} \quad$ The remaining states apply the civil law rule, ${ }^{246}$ which is effectively the opposite of the common enemy doctrine. Under the civil law rule, a landowner must accept the natural drainage of the land.

\section{Washington}

\section{Common Enemy Doctrine Does Not Apply to Seawater}

Grundy v. Thurston County, 55 Wn.2d 1 (2005)

Evelyne Grundy's neighbors, the Bracks, raised their existing seawall by 16-18 inches, making it 4 inches higher than hers. Grundy sued the Bracks for creating a nuisance, arguing that the uneven seawalls would make her property vulnerable to flooding. The Washington Supreme Court held that the common enemy doctrine did not apply to seawater, which meant that the Bracks could not use the doctrine as a defense for their actions. Almost every development affects drainage patterns, so most courts implementing this rule attempt to balance the interests of neighboring land owners against the benefit of development.

Policymakers may want to learn more about the doctrines in their particular state before designing a prohibition on hard armoring. ${ }^{247}$ These doctrines may prevent state agencies from preventing armoring without clear legislative guidance. Nothing in these doctrines, however, should prevent a state legislature from enacting a law to limit hard armoring.

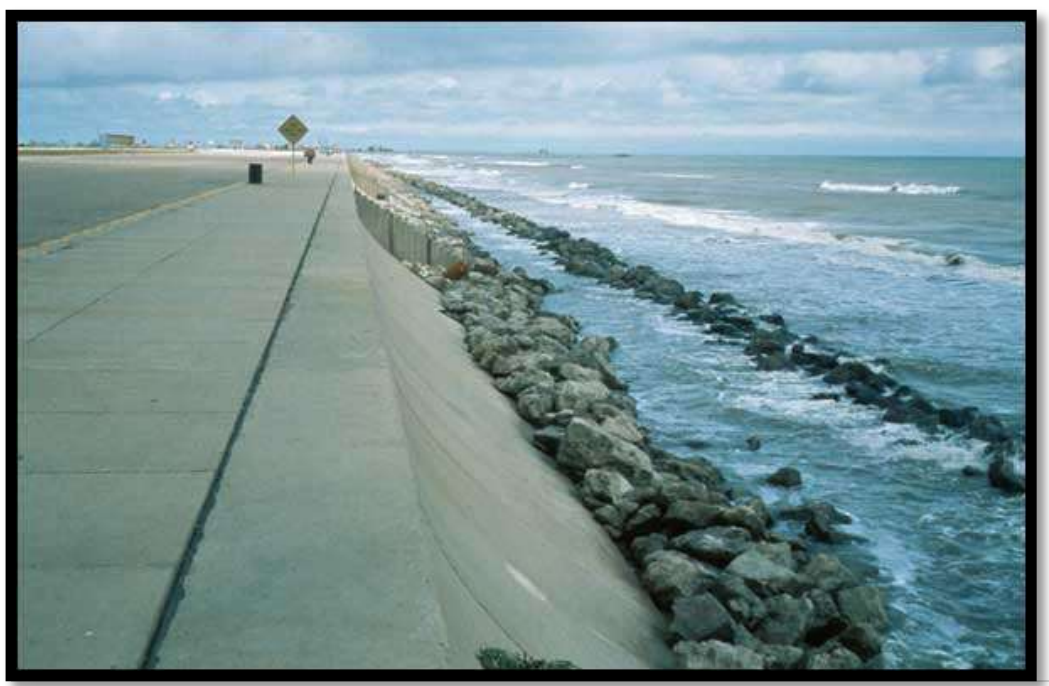

Hard structures, such as the Galveston seawall, can increase erosion of adjacent beaches. Source: USGS. 


\section{Prohibition and Permitting}

Total prohibition of coastal armoring would be most effective for protecting the long-term health of public beaches and for promoting managed retreat. However, most states that prohibit armoring actually prohibit armoring only in designated areas or under certain conditions. Courts in Oregon and North Carolina have upheld armoring prohibitions against takings challenges. ${ }^{248}$ For discussion of how prohibition of armoring relates to setback requirements, see the case study of Kaua'i, Hawaii, in Chapter 2 Setbacks.

\section{Texas Coastal Coordination Council ${ }^{249}$}

Texas (see inset) places a general prohibition on the construction of erosion response structures. This is then tempered by a clause that permits shore protection projects under certain limited circumstances. Specifically, the Coastal Coordination Council regulation that is cited (§501.14(k)(2), replaced by $\S 501.26$ (b)(2)) provides that shoreline protection projects are only permitted in order to protect community developments, public infrastructure, and "shall not be used solely to protect individual structures or properties." ${ }^{250}$ The regulations therefore effectively prohibit private shoreline armoring but allow government agencies to build armoring structures to defend public areas. Additional requirements in the Texas Open Beaches Act and Texas Dune Protection Act (Texas Natural Resources Code, Chapter 63), apply to structures that may affect dunes and public access to the beach.

\section{Texas Administrative Code $\S 15.6$}

\section{Concurrent Dune Protection and Beachfront Construction Standards}

(c) Prohibition of erosion response structures. Local governments shall not issue a permit or certificate allowing construction of an erosion response structure. Notwithstanding the general prohibition on constructing erosion response structures, a local government may authorize the construction of a structural shore protection project that conforms with the policies of the Coastal Coordination Council promulgated in 31 TAC $\S 501.14(\mathrm{k})(2)$. However, a local government may issue a permit or certificate authorizing construction of a retaining wall, as defined in $\$ 15.2$ of this title (relating to Definitions), under the following conditions. These conditions only apply to the construction of a retaining wall; all other erosion response structures are prohibited.

(1) A local government shall not issue a permit authorizing the construction of a retaining wall within the area 200 feet landward of the line of vegetation.

(2) A local government may issue a permit authorizing construction of a retaining wall in the area more than 200 feet landward of the line of vegetation. 


\section{Maine Coastal Sand Dune Rules ${ }^{251}$}

In 1979, following the most destructive storm Maine's coast had ever experienced, the state legislature passed a landmark bill known as the Coastal Sand Dune Rules, ${ }^{252}$ which established a permit program for building on sand beaches. The Maine Coastal Sand Dune Rules preclude construction that "unreasonably" creates a flood hazard, causes erosion to the beaches and dunes, interferes with sand movement or storage, or adversely impacts wildlife or recreational uses of beaches.

The Sand Dune Rules have two particularly interesting features relating to shore armoring (see excerpts from the Rules below). First, $\S 5$ (E) prohibits the building of new seawalls and the expansion of existing seawalls unless the expansion would be less damaging to the coastal sand dune system. This strikes a compromise between allowing existing seawalls to remain and protect the buildings that rely on those walls and preventing additional walls and new development in a vulnerable area.

The second notable feature, $\S 5$ (D), also acts to prevent new risky development. $\S 5$ (D) prohibits new development in shore areas that will be at risk from erosion or a two-foot sea level rise within 100 years. [It is important to note that this is a conservative estimate of sea level rise for the region. ${ }^{253}$ ] The law places the burden on the landowner to prove that a structure will not be vulnerable to erosion, and "reliance upon an existing seawall is not sufficient evidence of site stability" (see Fichter inset). Placing the burden of evidence on the private property owner both encourages private owners to learn about the hazards and preserves government resources.

Section 5 (D) also reduces the construction and armoring cycle that is usually presented by seawalls - in which a landowner is allowed to build a seawall, builds structures that raise the value of the property and necessitate the building of further seawalls that enable the building of further structures. By not allowing a landowner to rely on the presence of a seawall, the Maine Sand Dune Rules reduce the risk that landowners will develop in risk areas believing that the seawalls will protect them. This also reduces the risk of damage from a catastrophic failure of the seawall. 


\section{MAINe SAND DUNe RULES}

\section{$\S$ 5. Standards for All Projects}

\section{(C) Shoreline changes within 100 years}

A project may not be permitted if, within 100 years, the property may reasonably be expected to be eroded as a result of changes in the shoreline such that the project is likely to be severely damaged after allowing for a two foot rise in sea level over 100 years. Beach nourishment and dune restoration projects are excluded from this requirement.

\section{(D) Building size restrictions}

No building greater than 35 feet in height or covering a ground area greater than 2,500 square feet may be constructed in a coastal sand dune system unless the applicant demonstrates by clear and convincing evidence that:

(1) The site will remain stable after allowing for a two foot rise in sea level over 100 years, and

(2) The increased height will not have an unreasonable adverse effect on existing uses that rely on access to direct sunlight including, but not limited to: native dune vegetation and recreational beach use.

\section{Reliance upon an existing seawall is not sufficient as evidence of site stability ...}

\section{(E) Seawalls and similar structures}

No new seawall or similar structure may be constructed. No existing seawall or similar structure may be altered or replaced except . . . with a structure of different dimensions or in a different location that is farther landward . . . No existing seawall or similar structure may be altered or replaced except as provided below.

(1) Permanent alteration of different dimensions or location. With a permit from the department, a seawall or similar structure may be replaced with a structure of different dimensions or in a different location that is farther landward if the department determines that the replacement structure would be less damaging to the coastal sand dune system, existing wildlife habitat and adjacent properties than replacing the existing structure with a structure of the same dimensions and in the same location.

Note: The DEP encourages landowners to consider removing a seawall or similar structure and covering the area with sand and dune vegetation, or replacing the structure in a more landward position to reduce its influence on the beach and sand dune system. 


\section{Exactions}

An exaction, in this context, is a condition tied to the granting of a development permit by the government. The exaction requires a landowner to take some action or refrain from some action in order to mitigate the expected negative effects of the development. The rationale is that new development causes some external costs that the developer should be required to internalize.

In the context of coastal management, a state or local government could condition the granting of a permit on an agreement from the landowner not to build new coastal armoring. Exactions have become common development regulation tools and could also be useful for establishing rolling easements or implementing setbacks or building restrictions. ${ }^{254}$ For example, regulators could use exactions to require landowners to dedicate lands to buffer against flood risks or require landowners to remove structures as they become threatened. ${ }^{255}$ Exactions could also be used to limit redevelopment of damaged structures by granting redevelopment permits subject to conditions that structures be relocated as far inland on the lot as buildable space will allow, prohibit armoring, and require removal of threatened structures.

The California Coastal Commission uses exactions to limit future armoring. As a condition of a coastal development permit, landowners must agree not to seek a permit to protect structures with hard coastal armoring. ${ }^{256}$ A sample permit may specify, among other requirements, that:

A. By acceptance of this permit, the applicants agree, on behalf of themselves and all successors and assigns, that no bluff or shoreline protective device(s) shall ever be constructed to protect the development approved pursuant to this Coastal Development Permit, including, but not limited to, the residence with the attached garage, foundations, well, septic system, and driveway in the event that the development is threatened with damage or destruction from waves, erosion, storm conditions, bluff retreat, landslides, ground subsidence or other natural hazards in the future. By acceptance of this permit, the applicants hereby waive, on behalf of themselves and all successors and assigns, any rights to construct such devices that may exist under Public Resources Code Section 30235 or under Local Coastal Plans.

$\cdots$

C. In the event the edge of the bluff recedes to within 10 feet of the principal residence but no government agency has ordered that the structures not be occupied, a geotechnical investigation shall be prepared by a licensed geologist or civil engineer with coastal experience retained by the applicant, that addresses whether any portions of the residence are threatened by 
wave, erosion, storm conditions, or other natural hazards. The report shall identify all those immediate or potential future measures that could stabilize the principal residence without shore or bluff protection, including but not limited to removal or relocation of portions of the residence. The report shall be submitted to the Executive Director and the appropriate local government official. If the geotechnical report concludes that the residence or any portion of the residence is unsafe for occupancy, the permittee shall, within 90 days of submitting the report, apply for a coastal development permit amendment to remedy the hazard which shall include removal of the threatened portion of the structure. ${ }^{257}$

\section{Close Nexus and Rough Proportionality Requirements}

Three U.S. Supreme Court cases on exactions have established that exactions, particularly those that create a public easement across private property, are compensable takings unless they have both a "close nexus" between the purpose of requiring a permit and the requested exaction and a "rough proportionality" between the burden on the private property owner and the benefit to the public.

\section{Nollan v. California Coastal Commission, 483 U.S. 825 (1987)}

The Nollans owned beachfront property in Ventura County, California. A concrete seawall separated the beach portion of their property from the rest of the lot. The building on the lot was a small bungalow, but the Nollans wanted to replace the bungalow with a larger house. In order to do so, the Nollans were required to obtain a coastal development permit from the California Coastal Commission. The Commission granted the permit subject to the condition that the Nollans allow a public easement to pass across a portion of their beach property between the mean high tide line and the seawall. This easement would allow the public easier access to larger public beaches in the area. The Nollans objected to the easement and argued that the imposition of the easement constituted a taking of their property without just compensation.

The Commission argued that the new house would block the ocean view and contribute to "a 'wall' of residential structures that would prevent the public psychologically...from realizing a stretch of coastline exists nearby that they have every right to visit." ${ }^{258}$ This negative effect of the Nollans' development could be offset by the requested public easement. As discussed in the Takings Overview in Preliminary Matters, a regulation is generally not a taking if it substantially advances a legitimate government interest and if it does not deny the owner the economically viable use of his land. However, in the Nollan case, the Supreme Court held that the reducing the "psychological barrier" to public beach access was not a sufficiently legitimate state interest to be upheld. 
In a subsequent exactions case, Dolan v. City of Tigard, 512 U.S. 374 (1994), the Supreme Court further held that an exaction must have an "essential nexus" to the public policy being advanced and the burden on the private landowner must be roughly proportionate to the benefit to the public.

The Court decisions in Nollan and Dolan have not been consistently applied, and several state and federal courts have limited the principles in Nollan/Dolan to apply only to exactions that establish a public easement or require a public dedication of private land. ${ }^{259}$ The status of these rules has been further complicated by the Supreme Court's 2013 decision in Koontz (see discussion of Koontz in Preliminary Matters). This case law does not necessarily prevent the use of exactions to prohibit the building of seawalls and coastal armoring. Rather, it means that agencies must be careful when they shape the exaction and explain the public policy that they are trying to further with the exaction.

\section{Mitigation Fees}

Although not strictly speaking a managed retreat tool, mitigation fees can help governments fund other expensive managed retreat projects. Mitigation fees are fees that are assessed to landowners whose development actions burden or cause harm to other landowners or to the public.

In 2008, the California Court of Appeal for the $6^{\text {th }}$ District upheld a $\$ 5.3$ million mitigation fee intended to compensate the public for the lost recreation value of a beach that is expected to completely erode due to shoreline armoring that was approved for a poorly sited condominium development built before the Coastal Act. ${ }^{260}$ This demonstrates that even when armoring is allowed, it does not need to relinquish public rights to the coast. Mitigation fees, as mentioned, can help offset the costs of coastal development and make developers internalize some of the harms of their construction. However, policy makers should not rely on mitigation fees alone to regulate coastal development as, in the absence of other regulatory schemes, this could create a situation in which developers feel they can buy the coast. 


\section{MASSACHUSETTS ARMORING}

Massachusetts has about 1,500 miles of tidal shoreline (including seacoast, offshore islands, sounds, and bays). ${ }^{261}$ Almost $70 \%$ of the state's population resides in coastal counties and, excluding major urban areas such as Boston, 36,000 people live within 500 feet of the shore. ${ }^{262}$

Approximately $78 \%$ of the Massachusetts ocean-facing shore is exhibiting a long-term erosion trend. ${ }^{263}$ Statewide, the coastal shoreline is eroding roughly 0.56 feet per year. ${ }^{264}$ In some areas, though, this rate is substantially increased. The southwest shore of Nantucket, for example, is eroding at an average of 10-12 feet per year. ${ }^{265}$ The beach near Scituate has been eroding at a rate of 2 feet per year. ${ }^{266}$

Despite the threat this erosion poses to Massachusetts landowners and infrastructure, Massachusetts General Law Chapter 91, the Massachusetts Public Waterfront Act, requires authorization in order to build or alter structures constructed seaward of the mean high water line. ${ }^{267}$ Chapter 91 authorization is required for a range of engineering structures including piers, wharves, revetments, dams, and bridges. The Massachusetts Department of Environmental Protection (MassDEP) manages Chapter 91. Armoring coastal dunes is also implicitly prohibited by a regulatory performance standard that requires structures and activities not to interfere with the natural migration and constant changing of shape of coasts. Furthermore, an activity may not prevent a coastal dune from eroding and providing sand to other coastal resources. Massachusetts' regulatory prohibition on hard armoring is based on the recognition that hard armoring structures interfere with sedimentation and dune cycles that are vital to the coastal ecosystem.

Despite the presence of these regulations, almost $27 \%$ of Massachusetts' ocean-facing shoreline is protected by hard armoring, a number that does not include regions that may be protected by shore-perpendicular structures (such as groins). ${ }^{268}$ Approximately 140 miles of shoreline are covered by publicly owned coastal structures, and an additional 230 miles are covered by privately-owned structures. ${ }^{269}$ Many of these structures were built prior to modern coastal policies and regulations and until recently, no centralized database of coastal structures existed. ${ }^{270}$ A recent survey of Massachusetts identified 6,611 privately-owned coastal structures. ${ }^{271}$ The final inventory included 2,967 bulkheads/seawalls, 1,660 revetments, 1,969 groins/jetties, and 15 sandbag structures. The Boston Harbor region has the highest percentage of protected coastline at $58 \% .{ }^{272}$

Prior to construction of these shore protection structures, sediment contained in the coastal banks was available to replenish downdrift shorelines. ${ }^{273}$ The build-up of armoring along the coast has prevented this replenishment and has resulted in extensive loss and narrowing of recreational beaches, reduction or loss of lateral beach access, and the elimination or alteration of marine habitat in many areas, particularly along the South Shore of Massachusetts. ${ }^{274}$ Protection of private on-shore infrastructure has resulted in a loss of public access to these beaches and the public and ecological benefits they provide. 


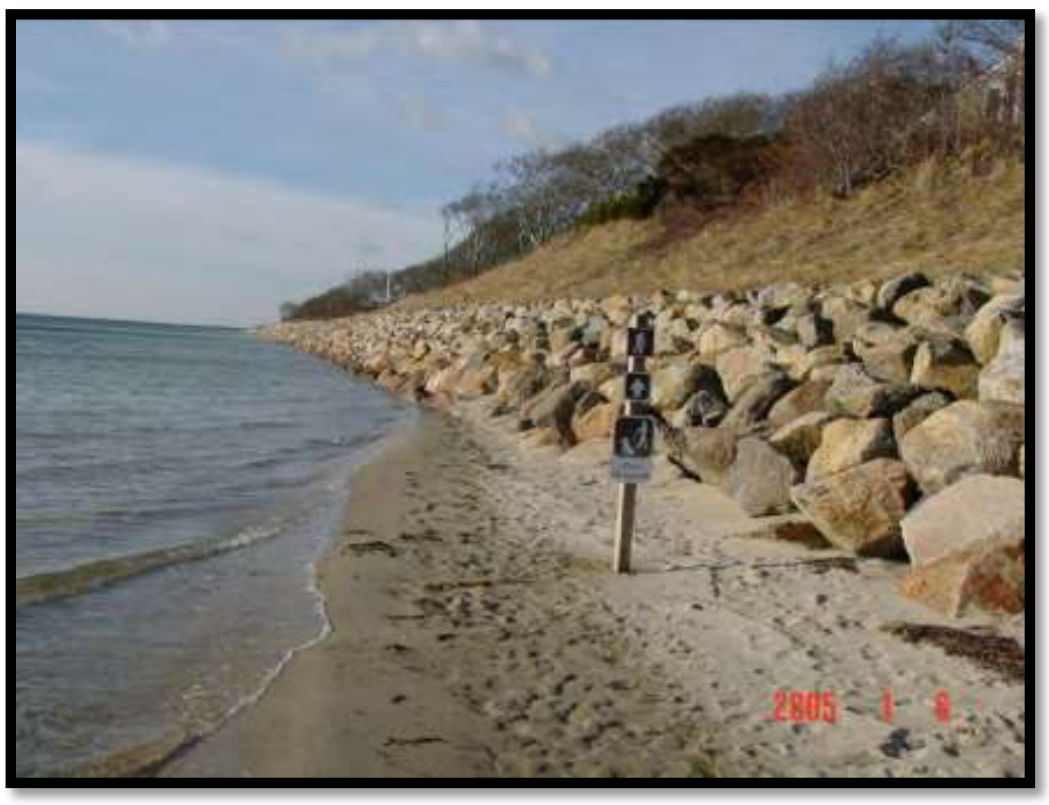

The loss of public lateral beach access due to shoreline armoring along the shore of Chatham, Massachusetts. Prior to revetment construction, a dry sandy beach provided lateral public beach access to a U.S. Fish and Wildlife property. Photo O'Connell, USGS.

In addition to the environmental costs, hard armoring structures present an on-going economic cost. According to a 2009 statewide study of public infrastructure along the Massachusetts coastline, almost $80 \%$ of coastal structures have outlived their supposed 50year lifespan. ${ }^{275}$ Unfortunately, the same survey shows that $85 \%$ of the infrastructure has gone unrepaired from 1958 to $2009 .{ }^{276}$ Based on 2006 figures, it is estimated that it would cost $\$ 31.5$ million a year for 20 years to make high priority fixes. ${ }^{277}$ After 2012 's Hurricane Sandy, the surveyed costs are sure to be underestimated.

In the town of Salisbury, with only 4 miles of shoreline exposed to the open ocean, 12 structures of a total of 5,570 feet of protection would require approximation $\$ 1.8$ million to bring all coastal structures to the condition as last repaired or originally constructed. ${ }^{278}$ Newbury, with only 1 mile of shoreline exposed to the open ocean, has 17 structures covering 5,025 that would require $\$ 2.1$ million to become optimal. ${ }^{279}$ All told, the price tag to fix the seawalls in Massachusetts was more than $\$ 600$ million in 2006 dollars. ${ }^{280}$ This $\$ 600$ million would only repair the walls; it would not be sufficient to expand their length or raise their height to protect against sea level rise and the increased intensity expected from future storms. ${ }^{281}$ For that, more than $\$ 1$ billion would be required. ${ }^{282}$

In an interview with the Boston Globe, S. Jefress Williams, a coastal marine geologist and scientist emeritus with the U.S. Geological Survey Woods Hole Science Center, said, "We are now facing a societal debate about how much people want to pay - and who pays - for coastal defense." ${ }^{283}$ In the same article, Rick Murray, a professor of earth science at Boston University and a Scituate selectman, put it more bluntly: "Not everything we love can be saved." 284 


\section{LESSONS LEARNED AND RECOMMENDATIONS}

- Take strong action. Coastal armoring has significant external costs to the long-term health of the shoreline and to public access to the coasts. A statewide prohibition or rigorous permitting requirements for coastal armoring is an effective method for preserving the coasts in those areas where feasible. (In many locations, such as certain kinds of urban waterfronts, this is not feasible.)

- Act quickly. Legislation and regulations should be enacted as soon as possible in order to limit the number and scope of existing structures that will be grandfathered in under the old permissive standards. Legislation should also limit, to the extent possible, the repair, rebuilding, and expansion of existing armoring. It should also transfer responsibility for funding the maintenance and replacement of existing structures to private landowners so that the costs of maintaining coastal armoring are internalized by coastal landowners.

- Use multiple tactics. Legislation, exactions, or agency policies prohibiting armoring should be coupled with setbacks, rolling easements, rebuilding restrictions and other managed retreat tools.

- Place the burden of proof on the landowner. Coastal development permits should not allow the existence of a seawall or other hard armoring to be sufficient evidence of the safety and stability of a development site. Placing the burden of proof on the landowner serves both to raise awareness with the development community and to save government resources. This will also limit harm in the case of a catastrophic event or failure of the armoring.

- Break the sea wall cycle whenever possible by preventing development that relies on the continued existence of coastal armoring. Such development will require substantial ongoing funding to repair, rebuild, and expand coastal armoring to keep it safe. Managed retreat is not only about re-locating existing communities but also about preventing new development in vulnerable areas.

- Requiring landowners to promise not to build coastal armoring in order to receive a development permit can be a powerful coastal development tool and can be used broadly to accomplish managed retreat. When exactions are used, agencies should be careful in how they spell out the legitimate government interest that is being served by the exaction and should be sure that the burden on the landowner is proportionate to the benefit to the public.

- Pursuing mitigation fees for public harms resulting from hard armoring (such as lost access to public beaches) can provide needed revenue to pursue other managed retreat policies 
but should be used only in combination with other regulatory policies so as to avoid the appearance of selling the coast.

- When coastal armoring has proven ineffective, been substantially damaged by storms, or encroached on public lands, governments can take this opportunity to require the removal of existing structures.

\section{FURTHER READING}

Meg Caldwell, No Day at the Beach: Sea Level Rise, Ecosystem Loss, and Public Access along the California Coast, 34 ECOLOGY L.Q. 533, 564-66 (2007).

Jennifer E. Dugan and David M. Hubbard, Ecological Effects of Coastal Armoring: A Summary of Recent Results for Exposed Sandy Beaches in Southern California, in PUGET SOUND SHORELINES AND the IMPACtS of ARMORING-PRoceedings of a State of the SCIENCE Workshop, May 2009: U.S. Geological SuRVey SCIENTIFic InVESTIGations RePort 2010-5254, 65-76 (Shipman, H., Dethier, M.N., Gelfenbaum, G., Fresh, K.L., and Dinicola, R.S., eds., 2010), available at http://pubs.usgs.gov/sir/2010/5254/pdf/sir20105254 chap19.pdf.

G.B. Griggs, The impacts of coastal armoring, 73 SHORE AND BEACH 1, 13-22 (2005).

The Heinz Center for Science, Economics, and the Environment, Evaluation of Erosion hazards: Prepared for the Federal Emergency Management Agency 23 (2000).

Massachusetts Coastal Infrastructure Inventory and Assessment Project: Summary Report (Massachusetts Department of Conservation and Recreation, Office of Waterways, 2009), available at www.mass.gov/eea/docs/czm/stormsmart/seawalls/public-inventory-report2009.pdf

James F. O'Connell, Shoreline armoring impacts and management along the shores of Massachusetts and Kauai, Hawaii, in Puget Sound Shorelines AND the IMPACTS OF ArMoringProceedings of a State of the SCIence Workshop, May 2009: U.S. Geological SurVey SCIentific INVESTIGATIONS REPORT 2010-5254, 65-76 (Shipman, H., Dethier, M.N., Gelfenbaum, G., Fresh, K.L., and Dinicola, R.S., eds., 2010), available at http://pubs.usgs.gov/sir/2010/5254/pdf/sir20105254 chap7.pdf.

U.S. Army Corps of Engineers, Low Cost Shore Protection: A Guide for local Government Officials (1981). 


\section{REFERENCES}

223 Shoreline Stabilization Techniques, New York State Department of Environmental Conservation, http://www.dec.ny.gov/permits/67096.html (last visited Aug. 9, 2013).

${ }^{224}$ Id.

${ }^{225}$ Cost estimates vary depending on material used and whether the estimate includes only material or also labor, repair, maintenance, and replacement costs. See Andrew J. Rella and John K. Miller, A Comparative Cost Analysis of Ten Shore Protection Approaches at Three Sites Under Two Sea Level Rise Scenarios (Hudson River Sustainable Shorelines Project, 2012) (noting that material alone for a bulkhead can range from $\$ 116$ to $\$ 1,200$ per linear foot); Thomas Ruppert, Sea-Level Rise and Drainage: Where the Water Hits the Road, Presentation Florida Sea Grant College Program, https://nrm.dfg.ca.gov/FileHandler.ashx?DocumentID=64899 (estimating $\$ 300$ to $\$ 4,000$ per linear foot for shoreline armoring); G.B. Griggs, The impacts of coastal armoring, 73 SHORE AND BEACH $1,13-22$ (2005) (giving an upper estimate of $\$ 7,800$ per linear foot for hard armoring solutions). Inset data on California cost of armoring from the Monterey National Marine Sanctuary, Resource Issues: Coastal Armoring, http://montereybay.noaa.gov/resourcepro/resmanissues/coastal.html (last visited Aug. 13, 2013). Other estimates place the cost at $\$ 400,000$ to $\$ 14$ million per kilometer. These numbers are likely to be higher in 2013 dollars. See M. Linham, C. Green and R. Nicholls, Costs of adaptation to the effects of climate change in the world's large port cities, WORK STREAM 2, REPORT 14 OF THE AVOID PROGRAMME (AV/WS2/D1/R14), 48 (2010), available at www.avoid.uk.net (summarizing literature estimates on seawall, dike, and hardening costs); Intergovernmental Panel on Climate Change Coastal Zone Management Subgroup, Strategies for adaptation to sea level rise: Report of the Coastal Zone Management Subgroup, response Strategies Working Group of the Intergovernmental Panel on Climate Change, The Hague: Ministry of Transport, Public Works and Water Management (1990) (providing estimates depending on type of armoring using 1989 dollars); R.J. Nicholls and S.P. Leatherman, Global Sea Level Rise, in As CLIMATE CHANGES: INTERNATIONAL IMPACTS AND IMPLICATIONS (Kenneth M. Strzepek and Joel Smith, eds., 1995) at 101 (noting that rural seawalls may cost between $\$ 0.4$ and 8.1 million per kilometer of seawall, and that urban seawalls are likely to be more expensive than rural seawalls); M. HEBURGER, H. COOLEY, P. HERRERA, P.H. GLEICK, AND E. Moore, The Impacts of Sea level Rise on the California CoAst. California Climate Change Centre: California $35-36$ (2009) (estimating \$4.4 million to \$27.5 million per kilometer for a one meter high dike along California).

${ }^{226}$ Stronger More Resilient New York, Chapter 3 Coastal Barriers p 49.

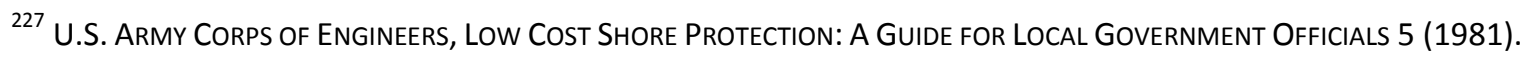

${ }^{228}$ See HEBURGER, supra note225, at 36 (noting that average maintenance costs for levees are about $10 \%$ per year of the costs of construction, and estimated maintenance costs for seawalls run from $1 \%-4 \%$ per year).

${ }^{229}$ See Rella and Miller, supra note 225 , at 3.

${ }^{230}$ For damage to ecosystems, see Jennifer Dugan, David Hubbard, Ivan Rodil, David Revell and Stephen Schroeter, Ecological effects of coastal armoring on sandy beaches, 29 MARINE ECOLOGY 160 (2008).

${ }^{231}$ See, e.g., Charles H. Fletcher, Robert Mullane, and Bruce Richmond, Beach Loss Along Armored Shorelines on Oahu, Hawaiian Islands, 13 Journal Of COAStAl ReSEARCH 209, 213 (1997); Owen Pilkey and H.L. Wright, Seawalls Versus Beaches, 4 Journal of COASTAL ReSEARCH (Special Issue) 4 (1988); N.C. Kraus and W.G. McDougal, The effects of seawalls on the beach: Part 1 , An updated literature review, 12 JOURNAL OF COASTAL RESEARCH 691 (1996); G. B. Griggs, The armoring of California's coast, in CALIFORNIA AND THE WORLD OCEAN '97 CONFERENCE, PROCEEDINGS: RESTON, VA., American Society of CiVIL Engineers 515-526 (O.T. Magoon, H. Converse, B. Baird, and M. Miller-Henson, eds., 1998); J.F. Tait and G.B. Griggs, Beach response to the presence of a seawall-A comparison of field observations, 58 SHORE AND BEACH 11-28 (1990); M. J. Hall and O. Pilkey, Effects of hard stabilization on dry beach widths for New Jersey, 7 JOURNAL OF COASTAL RESEARCH 771-785 (1991). 


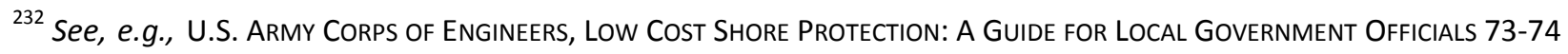
(1981).

${ }^{233}$ See Matthew linham and Robert Nicholls, Technologies for Climate Change Adaptation: CoAstal Erosion and FLOODING 40 (UNEP, 2010).

${ }^{234}$ See, e.g., Aram Terchunian, Permitting Coastal Armoring Structures: Can Seawalls and Beaches Coexist?, SPECIAL Issue 4 Journal of Coastal ReSeARCH 65, 67 (1988); H.J. Steetzel, A Model for Beach and Dune Profile Changes near Dune Revetments, Proceedings of Coastal Sediments '87 Conference, NeW Orleans, LA, May 12-14, 1987, p 87-97 (1987); W.G. McDougal, M.A. Sturtevant, and P.D. Komar, Field and Laboratory Investigations of the Impact of Shoreline Stabilization Structures on Adjacent Properties, ProCEEDINGS OF COASTAL SEDIMENTS '87 CONFERENCE, NEW ORLEANS, LA, MAY 12-14, 1987, p 961-973 (1987).

${ }^{235}$ New York City, Chapter 3: Coastal Barriers, 49, in A Stronger More ReSILIENT New York (New York City, 2013), available at http://www.nyc.gov/html/sirr/html/report/report.shtml.

${ }^{236}$ See Jennifer E. Dugan and David M. Hubbard, Ecological Effects of Coastal Armoring: A Summary of Recent Results for Exposed Sandy Beaches in Southern California, in PUGET SOUND SHORELINES AND THE IMPACTS OF ARMORING-

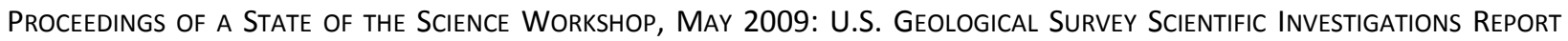
2010-5254, 65-76 (Shipman, H., Dethier, M.N., Gelfenbaum, G., Fresh, K.L., and Dinicola, R.S., eds., 2010), available at http://pubs.usgs.gov/sir/2010/5254/pdf/sir20105254 chap19.pdf; Jennifer Dugan David Hubbard, Ecological responses to coastal armoring on exposed sandy beaches, 74 SHORE AND BEACH 10-16 (2006); Dugan et al, supra note 230 .

${ }^{237}$ Quoted in Bruce Willey, Living on the Edge: A Saga of Seawalls, Who Wants Them, Who Doesn't, and the Fate of California's Disappearing Coastline, GOOD TIMES, Feb. 27, 2003, http://hydro.csumb.edu/essp\%20360/html/gdtimes 1.html.

238 See Dugan et al, supra note 230; I. Colombini and L. Chelazzi, Influence of marine allochthonous input on sandy beach communities, 41 OCEANography ANd Marine Biology: AnNuAl ReVIeW, 115 (2003); Jennifer Duncan, David Hubbard, M. McCrary, and M. Pierson, The response of macrofauna communities and shorebirds to macrophyte wrack subsidies on exposed beaches of southern California, 58S ESTUARINE, COASTAL AND SHELF SCIENCE, 133 (2003).

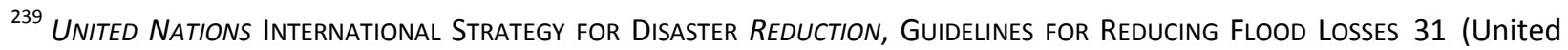
Nations, 2004), available at www.unisdr.org/files/558 7639.pdf.

${ }^{240}$ See, e.g., Brian Handwerk, New Orleans Levees Not Built for Worst Case Events, NATIONAL GEOGRAPHIC NEWS, Sep. 2, 2005, http://news.nationalgeographic.com/news/2005/09/0902 050902 katrina levees.html (last visited Aug. 7, 2013).

${ }^{241}$ See, e.g., Norimitsu Onishi, Seawalls Offered Little Protection Against Tsunami's Crushing Waves, NEW YoRK TIMES, Mar. 13, 2011, http://www.nytimes.com/2011/03/14/world/asia/14seawalls.html?pagewanted=all (last visited Aug. 7, 2013).

${ }^{242}$ See Wendy B. Davis, Reasonable Use Has Become the Common Enemy: An Overview of the Standards Applied to Diffused Surface Water and the Resulting Depletion of Aquifers, 9 AlB. L. ENVIRONMENTAL OUTLOOK JOURNAL (2004).

${ }^{243}$ See JOHn W. JOHnSON, United StATES WATER LAW: AN INTRODUCTION 90 (CRC Press, 2009).

${ }^{244}$ Id. States that have adopted the reasonable use test include: Alaska (Weinberg v. Northern Alaska Development Corp, 384 P.2d 450 (Alaska 1963)); Arkansas (Harris v. Brooks, 225 Ark. 444, 283 S.W. 2d, 134 (1955)); California (Tulare Irrigation Dist. v. Lindsay-Strathmore Irrigation Dist., 3 Cal. 2d 489, 45 P.2d 972 (Cal. 1935)); Connecticut (Bielonko v. Blanchette Builders, Inc., 1999 WL 68650 (Conn. Super. Feb. 2, 1999); Page Motor Co. v. Baker, 438 A.2d 739 (Conn. 1980)); Delaware (Weldin Farms, Inc. v. Glassman, 414 A.2d 500 (Del. 1980); Trustees of the Village of Arden v. Unity Construction Company, 2002 WL 1271677 (Del. Ch. May 31, 2002)); Florida (Westland Skating Center, Inc. v. Gus Machado Buick, Inc., 542 So.2d 959, 962 (Fla. 1989)); Hawaii (Association of Apartment Owners of Wailea Elua v. Wailea Resort Co., 58 P.3d 608, 617 (Hawaii 2002)); Kentucky (Klutey v. Commonwealth, Dept. of Highways, 428 S.W.2d766 (Ky. 1967)); Massachusetts (DeSanctis v. Lynn Water and Sewer Commission, 
666 N.E.2d 1292 (Mass. 1996)); Minnesota (Kral v. Boesch, 557 N.W.2d 597 (Minn. 1996)); Mississippi (Hall v. Wood, 443 S.2d 834, 840, n.1 (Miss. 1983)); Missouri (Heins Implement Co. v. Missouri Highway \& Transportation Commission, 859 S.W.2d 681, 689 (Mo. 1993)); Nevada (County of Clark v. Powers, 611 P.2d 1072 (Nev. 1980)); New Hampshire (Dudley v. Beckley, 567 A.2d 573, 574 (N.H. 1989); Franklin v. Durgee, 51 A.911 (N.H. 1901)); New Jersey (Sheppard v. Frankford, 617 A.2d 666, 668 (N.J. 1992)); New Mexico (Gutierrez v. Rio Rancho Estates, Inc., 605 P.2d 1154 (N.M. 1980)); North Carolina (BNT Company v. Baker Precythe Dev. Co., 564 S.E.2d 891, 896 (N.C. 2002)); North Dakota (Burlington Northern and Santa Fe Railway Company, v. Benson County Water Resource District, 618 N.W.2d 155, 160 (N.D. 2000)); Ohio (McGlashan v. Spade Rockledge Terrace Condo Development Corp., 402 N.E.2d 1196 (Ohio 1980)); Rhode Island (Zannini v. Arboretum Development, 1998 WL 1017288 (R.I. Super. July 7, 1988) (unpublished)); Utah (Morgan v. Quailbrook Condominium Co., 704 P.2d 573 (Utah 1985)); West Virginia (Graham V. Beverage, 566 S.E.2d 603, 612 (W. Va. 2002)); and Wisconsin (Wisconsin v. Deetz, 224 N.W.2d 407 (Wisc. 1974)).

${ }^{245}$ States that maintain a modified common enemy doctrine include: Alabama (Peak v. Parks, 2003 WL 21489412 (Ala. Civ. App. June 30, 2003) (requiring the plaintiff to prove the defendant acted with wontonness); District of Columbia (Ballard v. Ace Wrecking Co., 289 A.2d 888, 890 (D.C. 1971)); Indiana (Romine v. Gagle, 782 N.E.2d 369 (In. 2003)); Kansas (Williamson v. Hays, 64 P.3d 364 (Kan. 2003)); Maine (Johnson v. Whitten, 384 A.2d 698 (Me 1978)); Montana (Montana Dept. of Highways v. Feenan, 752 P.2d 182, 184 (Mont. 1988)); Nebraska (Schott v. Hennings, 2000 WL 279898 (March 14, 2000)); Oklahoma (Mattoon v. City of Norman, 617 P.2d 1347, 1349 (Ok. 1980)); South Carolina (Silvester v. Spring Valley Country Club, 543 S.E.2d 563 (S.C. 2001)); and Virginia (Mullins v. Greer, 311 S.E.2d 110, 112 (Va. 1984)).

${ }^{246}$ States that use the civil law rule include: Arizona (Gillespie Land \& Irrigation Co. v. Gonzalez, 379 P.2d 135, 146 (Az. 1963) ( holding that one who alters a natural watercourse will be liable for its inability to carry away waters flowing into it); Colorado (Bittersweet Farms, Inc., v. Zimbelman, 976 P.2d 326 (Colo. 1998); Hoff v. Ehrlich, 511 P.2d 523 (Colo. 1973) (finding that dominant estate has easement in lower estate for drainage of surface water; the court does not use the term Civil Law, but the stated rule is similar); Georgia (McMillen Development Corp. v. Bull, 188 S.E.2d 491 (Ga. 1972)); Idaho (Utter v. Gibbins, 48 P.3d 1250 (Idaho 2002)); Illinois (Dessen v. Jones, 551 N.E.2d 782, 786 (III. 1990)); lowa (Grace Hodgson Trust v. McClannahan, 569 N.W.2d 397 (lowa 1997); O’Tool v. Hathaway, 461 N.W.2d 161 (lowa 1990)); Louisiana (Crr v. Oake Tree Apartments, 786 So.2d 230, 235 (La. 2001)); Maryland (Mark Downs, Inc., v. McCormick Properties, Inc., 441'A.2d 1119 (Md. App. 1982)(explaining that the civil law rule, while still applicable, has been modified by a reasonableness of use qualifier)); Michigan (Kernan v. Homestead Development Co., 591 N.W.2d 369, 372 (Mich. 1998)); Oregon (Wellman v. Kelley, 252 P.2d 816, 821 (Oregon 1953)); Tennessee (Zollinger v. Carter, 837 S.W.2d 613 (Tenn. 1992)); and Texas (Jefferson County Drainage District No. 6 v. Lower Neches Valley Authority, 876 S.W.2d 940 (Texas 1994)).

${ }^{247}$ Outliers to the common enemy doctrine, modified doctrine, reasonable use test, and civil law rule, include: Pennsylvania, which adheres to the Common Enemy doctrine without modification (and then only in urban areas) (Fazio v. Fegley Oil Co., Inc., 714 A.2d 510 (Penn. 1998)); Vermont, which uses nuisance language and trespass analysis to determine liability (Canton v. Graniteville Fire District No. 4, 762 A.2d 808 (Vt. 2000)); and Wyoming, which relies on negligence laws rather than adopting any of the standard rules (Tompkins v. Byrtus, 267 P.2d 753 (Wyo. 1954).

${ }^{248}$ See Shell Island Homeowners Ass'n v. Tomlinson, 134 N.C. App. 217 (1999); Stevens v. City of Cannon Beach, 317 Or. 131 (1993).

24931 TeXas Administrative CODE, Part 16, $\S 501$ et. seq. Full text is available online at http://info.sos.state.tx.us/pls/pub/readtac\$ext.ViewTAC?tac view=3\&ti=31\&pt=16.

25031 TEXAS ADMINISTRATIVE CODE $\S 501.26(\mathrm{~b})(2)(\mathrm{k})(2)$. For more information on the repeal of $\S 501.14$ and adoption of $\S \S 501.16$ - 501.34, see 29 TEXAS REGISTER 7038 (July 23, 2004), and notice at http://texinfo.library.unt.edu/texasregister/html/2004/oct01/adopted/31.NATURAL\%20RESOURCES\%20AND\%20CONSERVATION.html (last visited Aug. 13, 2013).

${ }^{251}$ Natural Resources Protection Act, 38 M.R.S. §§ 480-A to 480-GG (2008) (Maine). 
${ }^{252}$ Maine Department of Environmental Protection, Natural Resources Protection Act, Chapter 355, Coastal Sand Dune Rules (1983), available at http://www.seagrant.umaine.edu/coastal-hazards-guide/permitting-andrules\#355.

${ }^{253}$ See U.S. Global Change Research Program, Second National Assessment (2009), noting that "Sea level rise in this region [Northeast U.S.] is projected to rise more than the global average" (Northeast), and that "recent estimates of global sea-level rise substantially exceed the IPCC estimates, suggesting sea-level rise between 3 and 4 feet in this century" (Coasts), but noting that melting of the Greenland or Antarctic ice sheets could yield even higher estimates (Global Climate Change).

${ }^{254}$ See J. Peter Byrne and Jessica Grannis, Coastal Retreat Measures, in The LAW Of AdAPTATION to Climate ChANGE (Michael Gerrard and Katrina Kuh, eds., 2012).

255 These types of exactions impose one form of "rolling easement" policy. See James G. Titus, Rising Seas, Coastal Erosion, and the Takings Claus: How to Save Wetlands and Beaches Without Hurting Property Owners, 57 MARYLAND LAW RevieW 1279, 1309, 1357-58 (1998); see also Meg Caldwell, No Day at the Beach: Sea Level Rise, Ecosystem Loss, and Public Access along the California Coast, 34 ECOLOGY L.Q. 533, 564-66 (2007); EPA, ANTICIPATORY PLANNING FOR SEA-LEVEL RISE ALONG THE COAST OF MAINE 6-12 (1995), available at

http://epa.gov/climatechange/effects/downloads/maine_0.pdf.

${ }^{256} 20$ CAL. PUB. RES. CODE §§ 30235, 30607; see also Caldwell, supra note 255, at 565-66.

${ }^{257}$ See Caldwell, supra note 255 , at 564.

${ }^{258}$ Nollan v. California Coastal Comm'n, 483 U.S. 825, 828 (1987) (internal quotations omitted).

${ }^{259}$ See W. Andrew Gowder, Jr., Recent Developments in Exactions and Impact Fees: Public Dedications Required of Private Land, 44 THE URBAN LAWYER 667 (2012); lowa Assurance Corp. v. City of Indianola, 650 F.3d 1094 (8 ${ }^{\text {th }}$ Cir. 2011); West Linn corporate Park, LLC v. City of West Linn, 428 F. App'x 700 ( $9^{\text {th }}$ Cir. 2011); Conklin Development v. City of Spokane Valley, 448 F. App'x 687 ( $9^{\text {th }}$ Cir. 2011) (noting that “Nollan/Dolan has not been extended 'beyond the special context' of adjudicative land use exactions that involved dedications of property so onerous that, outside the exactions context, they would be deemed per se physical takings." Id. at 689); Krupp v. Breckenridge Sanitation District, 19 P.3d 687, 697 (Colo. 2001); Portland v. Tualatin Hills Park \& Recreation District, 62 P.3d 404, 411 (Or. Ct. App. 2003).

${ }^{260}$ Ocean Harbor House Homeowners Ass'n v. Cal. Coastal Comm’n, 163 Cal. App. 4th 215 (2008).

${ }^{261}$ U.S. Census Bureau, Statistical AbStract of the United States 225, Table 364 (2012).

262 The Heinz Center for SCIence, Economics, and the Environment, Evaluation of Erosion hazards: Prepared for the Federal Emergency Management Agency 23 (2000).

${ }^{263}$ See O'Connell, Shoreline Armoring Impacts, supra note 154.

${ }^{264}$ Woods Hole Oceanographic Institution, Evaluation of Coastal Erosion Hazards: Results from a national Study and a Massachusetts Perspective, August 2001, https://www.whoi.edu/fileserver.do?id=74547\&pt=2\&p=88768; James O'Connell, Historic Shoreline Change Mapping and Analysis Along the Massachusetts Shore, Proceedings of the Tenth Symposium of Coastal and Ocean Management, Coastal Zone, Boston, MA (1997).

${ }^{265}$ Woods Hole, supra note 264.

${ }^{266} / d$.

${ }^{267}$ Massachusetts Public Waterfront Act, Mass. Gen. Laws ch. $91 \S \S 1$ et. seq.

${ }^{268}$ See Massachusetts Office of Energy and Environmental Affairs, StormSmart Coasts- Inventories of Seawalls and Other Coastal Structures, available at http://www.mass.gov/eea/agencies/czm/program-areas/stormsmartcoasts/seawall-inventory/ (Last visited Aug. 9, 2013). 
269 Jeremy Fontenault, Nathan Vinhateiro, Kelly Knee, Mapping and Analysis of Privately-OWNed CoAStal Structures ALONG THE MASSACHUSETTS SHORELINE 1 (2013), available at http://www.mass.gov/eea/agencies/czm/programareas/stormsmart-coasts/seawall-inventory.

270 Id.

${ }^{271}$ Id.

272 J.F. O'Connell, Shoreline Armoring Impacts and Management Along the Shores of Massachusetts and Kauai,

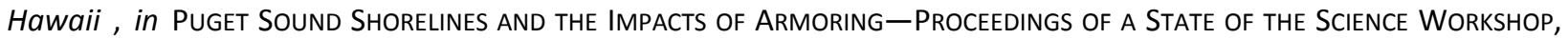
MAY 2009 65, 65 (H. Shipman et al. eds., 2010), citing State of Massachusetts, 2010, South shore coastal hazards characterization atlas: Boston, Mass., Office of Coastal Zone Management, available at www.mass.gov/eea/docs/czm/stormsmart/seawalls/boston-harbor/boston.pdf.

${ }^{273} / d$.

${ }^{274}$ Id.

275 See Beth Daley, Fighting a losing battle with the sea, THE Boston GLOBE, Apr. 3, 2011, http://www.boston.com/news/science/articles/2011/04/03/fighting a losing battle with the sea/?page=2 (last visited Aug. 9, 2013); Jessica Bartlett, Sandy puts South Shore's seawalls in spotlight, THE BOSTON GLOBE, Nov. 4, 2012, $\quad$ http://www.bostonglobe.com/metro/regionals/south/2012/11/04/sandy-puts-south-shore-seawallsspotlight/Y1LPUWFRFgBlj2mHW2WL2J/story.html (Last visited Aug. 9, 2013). See also MASSACHUSETTS COASTAL INFRASTRUCTURE INVENTORY AND ASSESSMENT PROJECT: SUMmARY REPORT (Massachusetts Department of Conservation and Recreation, Office of Waterways, 2009), available at www.mass.gov/eea/docs/czm/stormsmart/seawalls/publicinventory-report-2009.pdf (noting that only 15\% of coastal armoring structures in Massachusetts are less than 50 years old).

276 See MASSACHUSETTS SUMMARY REPORT, supra note 275; Bartlett, supra note 275.

${ }^{277}$ See Bartlett, supra note 275.

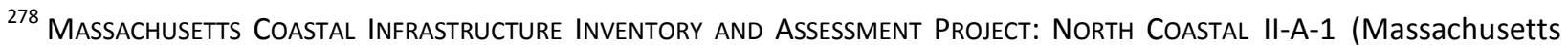
Department of Conservation and Recreation, Office of Waterways, 2009), available at www.mass.gov/eea/docs/czm/stormsmart/seawalls/north-shore/salisbury-essex.pdf.

${ }^{279}$ Id., at III-A-1.

${ }^{280}$ The Commonwealth is responsible for 38.41 miles of structure and the municipalities are responsible for 100.73 miles of structure. The total assessed value for repairs in 2006 dollars is $\$ 626,798,185$. MASSACHUSETTS SUMMARY REPORT, supra note 275 , at 6.

${ }^{281}$ Daley, supra note 275.

${ }^{282}$ Id., quoting the Massachusetts Department of Conservation and Recreation.

283 Id.

${ }^{284}$ Id 
Columbia Center for Climate Change Law

84 | P a g e 


\section{CHAPTER 4}

\section{REBUILDING RESTRICTIONS}

Catastrophic events raise questions not only about how to respond to the immediate damage to physical structures but also how to prevent future damage from reoccurring. Rebuilding restrictions - policies and guidelines that shape owners' responses to property damage - have the potential not only to promote repairs and modifications that will protect against future disasters but also to encourage property owners to retreat from vulnerable shoreline.

Rebuilding restrictions generally fall into one of two categories:

i. Limited Resilient Rebuilding policies require that damaged structures be replaced by more resilient structures, be built at higher elevations, or be moved further from the coast.

ii. Conditional Rebuilding policies require that property owners agree to certain conditions before they are allowed to rebuild structures. Owners might be asked to agree not to build protective armoring, to purchase insurance, to remove structures when threatened by erosion or inundation, or to be limited in the number of times they can rebuild. See Chapters 2 and 3 on Setbacks and Prohibiting Armoring for further discussion.

Policies that prohibit rebuilding entirely may constitute takings under the $5^{\text {th }}$ Amendment (see Takings Discussion in Preliminary Matters) and may therefore require governments to compensate landowners for the loss of their property. ${ }^{285}$ As a result, most governments use one of the two categories above. Policies restricting a property owner's ability to rebuild are also less likely to be considered takings if the guidelines or legislation clearly states the public safety and cost avoidance goals of the policy.

Rebuilding restrictions gradually phase out high-risk uses of coastal property, providing long-term cost savings by avoiding repetitive repairs to private property and public infrastructure. ${ }^{286}$ Rebuilding restrictions can also be used to promote managed retreat by requiring property owners to build further from the coasts (using setback requirements) or by raising the costs (financial and time) of rebuilding such that landowners relocate further inland.

Building or rebuilding restrictions may be implemented at the state level by adding conditions to public funding or passing specific legislation and at the local level by updating building codes, creating land use plans that designate coastal areas, or changing zoning regulations, among other possibilities. 


\section{Prior Non-Conforming Use}

Zoning law has an established practice for prior non-conforming uses. Once a use has been permitted on a property, the landowner has an expectation that the use will be permitted to continue to exist, even if the regulations change. ${ }^{287}$ This same principle applies to building codes and regulations. ${ }^{288}$ The old uses and buildings are grandfathered in under the old regulations. In some states, when a building is demolished and rebuilt (as in the aftermath of a coastal storm) or modified extensively the non-conforming use is still permitted to continue, ${ }^{289}$ but in others, once a building is destroyed, its successor must comply with the latest regulations. ${ }^{290}$

In the case of managed retreat, policy makers should put new zoning requirements and building code regulations into place as soon as possible so as to apply to the most new developments. Any delay will mean more development grandfathered in under the old regulations. Furthermore, policy makers should make clear guidelines to establish under what circumstances the new regulations will apply. For example, does a house have to rebuild to the new regulations if it is damaged $50 \%$ of its value, or only $25 \%$ ? Making these decisions and setting these guidelines in place before a disaster will facilitate enforcing them later.

\section{FEDERAL REQUIREMENTS}

Building restrictions are primarily a state and local issue, implemented through state legislation and local zoning regulations and building codes. However, federal agencies that provide disaster relief funding often place limitations on that funding that affect rebuilding decisions.

\section{National Flood Insurance Program (NFIP)}

Created by Congress in 1968 and administered by FEMA, the NFIP encourages states and municipalities to manage development in floodplains by offering flood insurance in areas that have adopted minimum regulations. ${ }^{291}$ This is a significant incentive, as homeowners are not eligible to receive federally backed mortgages without flood insurance, and private insurers have largely abandoned the market. Through mapping, insurance rate-setting, and developing minimum floodplain regulations, the NFIP affects how state and local governments adapt to sea-level rise.

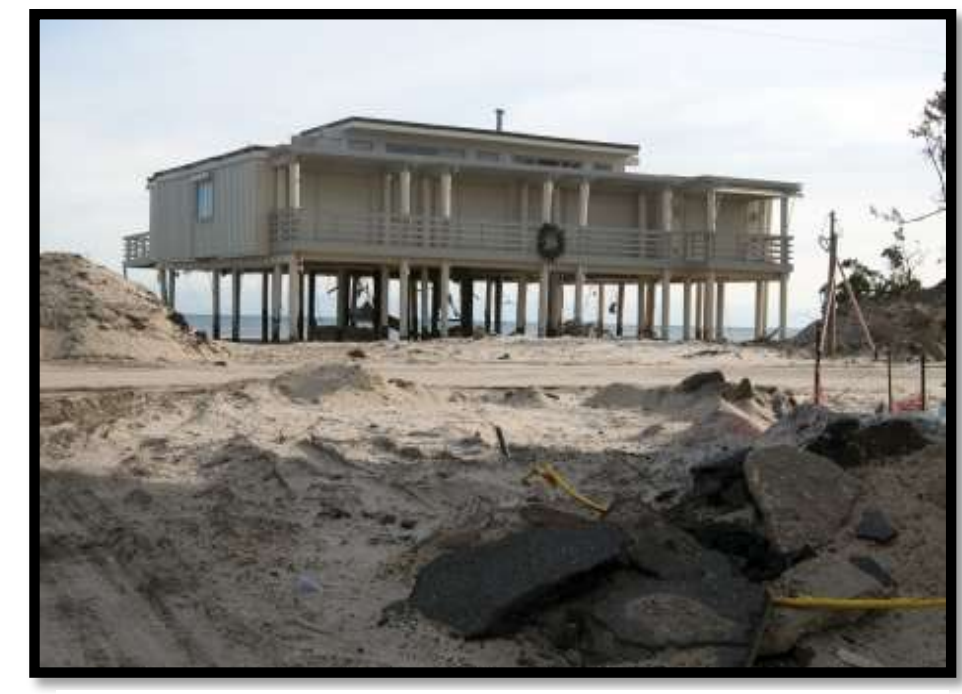

Residential home being raised to adhere to Base Flood Elevations. Photo courtesy of FEMA 
A community participating in the NFIP must adopt and enforce a floodplain management ordinance that minimizes future flood risks to new or existing construction. ${ }^{292}$ The NFIP requires communities adhere to building requirements or set standards for construction in flood-prone areas (see inset for example of NFIP requirement). Communities that participate in NFIP but fail to enforce these standards are prohibited from receiving flood insurance, federal grants and loans, federal disaster assistance, federal mortgage insurance, or federal funding for the acquisition or construction of structures located in the floodplain. ${ }^{293}$

Unfortunately, the Flood Insurance Rate Maps (FIRMs) and Special Flood Hazard Areas (SFHAs) that are used to implement the NFIP policies and identify vulnerable areas are often out of date. ${ }^{294}$ New digitized maps are being created, but they are often based on data from paper maps decades old and are slow to be created. Congress has cut map funding by more than half since 2010 , from $\$ 221$ million down to $\$ 100$ million in $2013 .{ }^{295}$ Additionally, new maps do not account for increased future risks that will be presented due to sea level rise. ${ }^{296}$ Thus, the more stringent NFIP regulations often do not apply to endangered areas.

Furthermore, the NFIP has been criticized for providing subsidized insurance to homeowners in vulnerable areas, thereby providing the means and incentive for owners to build and rebuild in flood-prone areas. The Biggert-Waters National Flood Insurance Reform Act of 2012 has addressed some of these concerns by directing FEMA to raise flood insurance rates to reflect actuarial risk, but this will be slow to phase in and to change the public mindset. (Read more about NFIP reforms in the NFIP overview in Preliminary Matters.)

\section{NFIP Requirements for Participation of Communities in NFIP 60.3(c)(5)}

Communities must: Require, for all new construction and substantial improvements, that fully enclosed areas below the lowest floor that are usable solely for parking of vehicles, building access or storage in an area other than a basement and which are subject to flooding shall be designed to automatically equalize the hydrostatic flood forces on exterior walls by allowing for the entry and exit of floodwaters. Designs for meeting this requirement must either be certified by a registered professional engineer or architect or meet or exceed the following minimum criteria: A minimum of two openings having a total net area of not less than one square inch for every square foot of enclosed area subject to flooding shall be provided. The bottom of all openings shall be no higher than one foot above grade. Openings may be equipped with screens, louvers, valves, or other coverings or devices provided that they permit the automatic entry and exit of floodwaters. 
NFIP - Building Requirements in Special Flood Hazard Areas (SFHAs)

A local permit is required for all development in the SFHA $^{297}$ as it is designated on a local FIRM. Proposed development projects must meet all NFIP and local requirements in order to obtain a permit ${ }^{298}$ and additional federal and state permits may be required, especially in areas of particular environmental conservation importance. Federal permits, for example, may be required by the U.S. Army Corps of Engineers for development near wetlands, barrier islands, or navigable waterways. ${ }^{299}$

The NFIP also requires that proponents of new development ensure that the structure will not increase the flood hazard to other properties. ${ }^{300}$ For example, all projects in the regulatory floodway must undergo an encroachment review to determine what effect they will have on flood flows. $^{301}$

\section{NFIP - Building \& Rebuilding Requirements}

When damage to a building exceeds $50 \%$ of a structure's pre-disaster value, the NFIP places conditions on rebuilding to promote resiliency and prevent repetitive losses. ${ }^{302}$ This could include raising the house above the flood elevation. ${ }^{303}$ The elevation requirement can be met by using elevation on fill, piles, posts, piers, columns, walls or a crawlspace.

New construction (including repairs, remodeling, and additions) in coastal flood hazard zones ( $V$ and $A$ zones) must meet minimum NFIP and community standards. ${ }^{304} \mathrm{~A}$ summary of general construction requirements set forth by FEMA can be found in the table on page $90 .^{\ddagger \neq \ddagger}$

Construction requirements in $\mathbf{V}$ zones are more stringent than those in $\mathbf{A}$ zones because $\mathrm{V}$ zones face increased flood, wave, flood borne debris, and erosion hazards. However, as can be seen in the table on the next page FEMA strongly recommends that buildings in Coastal $A$ zones be designed and constructed to $\mathbf{V}$ zone standards. ${ }^{305}$

\section{Useful Definitions}

\section{Substantial Damage}

Damage of any origin sustained by a structure to its pre-damaged condition would equal or exceed $50 \%$ of the market value or replacement cost of the structure before the damage occurred.

\section{Zone}

Coastal areas subject to inundation by the 100 year-flood event with additional hazards associated with storminduced wave action ( $V$ for velocity).

Both $\mathrm{A}$ and $\mathrm{V}$ zones are subject to mandatory insurance requirements and building restrictions.

\section{Coastal A Zone}

Coastal areas subject to inundation by the 100year-flood event. A zones are generally found further inland than $\mathrm{V}$ zones, but in some areas, particularly riverine areas, no $\mathrm{V}$ zones are present and $\mathrm{A}$ zones are located immediately along the shore.

\footnotetext{
${ }^{\ddagger \ddagger \ddagger}$ For a complete guide of requirements and recommendations for new constructions as well as repairs, remodeling, and additions, see FEMA Technical Fact Sheet No. 2, Home Builder's Guide to Coastal Construction: Summary of Coastal Construction Requirements and Recommendations (2005).
} 
FEMA requirements set a baseline, but local governments can and often should impose more restrictive requirements in floodplains. For example, local governments should encourage or require new construction in the Coastal $A$ zone to comply with $V$ zone standards, as climate change will often redraw the map lines on vulnerability and buildings in A zones may find themselves faced with $\vee$ zone level hazards. Building restrictions are a proactive measure and do not affect existing buildings, so implementing strict standards now will help ensure that buildings can withstand the hazards they will face in the future.

Disasters may present an opportunity to improve resilience by enforcing recent rebuilding restrictions in areas with pre-existing development. If a building is located below the 100-year flood elevation and is substantially damaged (or substantially improved), even if the building was constructed before any elevation requirements were issued, NFIP regulations state that the home must be brought into compliance with the local government's flood damage prevention regulations. ${ }^{306}$

NFIP rebuilding conditions emphasize accommodation - adapting a structure to permit future flooding to occur without causing damage - rather than retreat. This limits the amount of repetitive damage that communities experience, but it does not remove the risk of future flood events and it does not reduce the burden on local governments to continue to provide and maintain public infrastructure in vulnerable areas. NFIP also does not require communities to limit population densities or use intensity in flood-prone areas, so communities would have to take additional actions beyond the NFIP requirements in order to truly reduce their exposure to flood-damage.

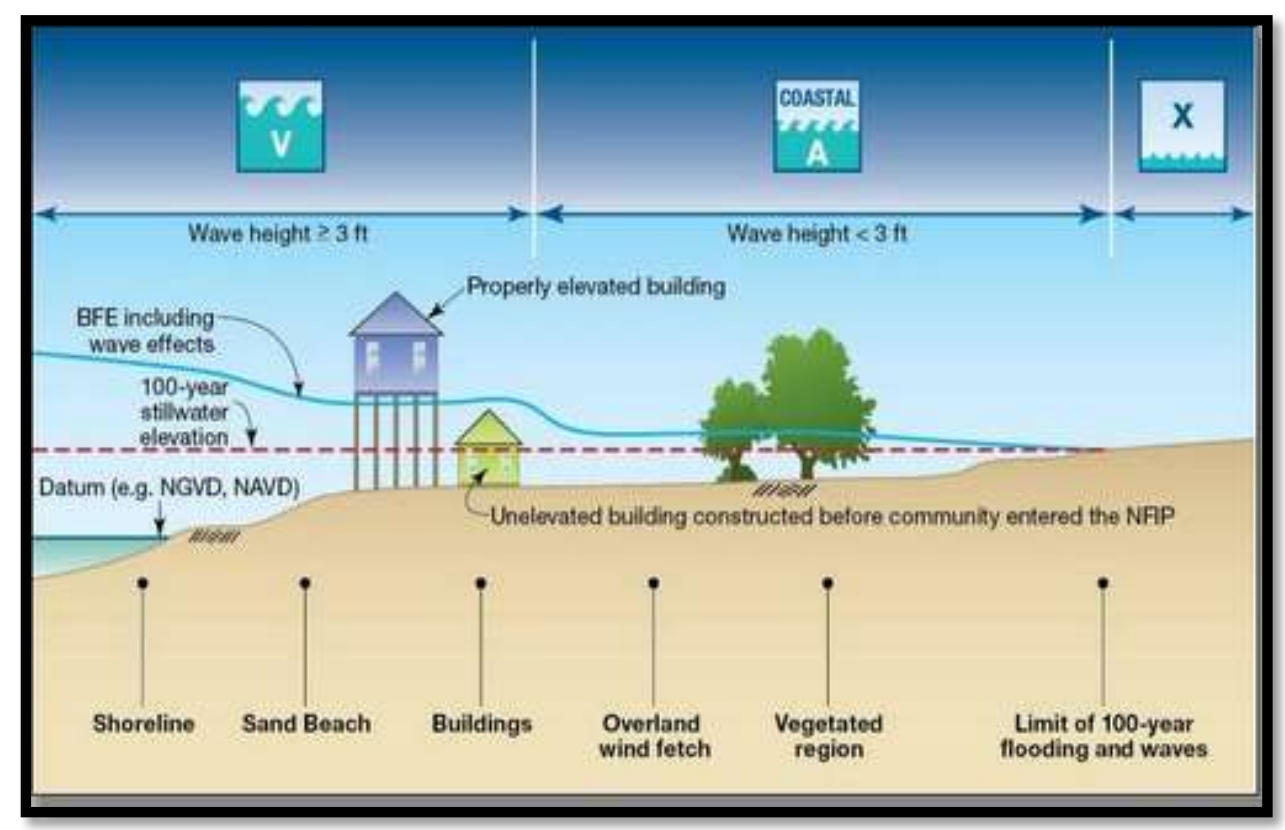

Example of building restrictions in V and coastal A zones. Graphic:

FEMA Region II. 


\section{FEMA General Requirements and Recommendations for New Construction}

\begin{tabular}{|c|c|c|c|}
\hline & V V Zone & $\begin{array}{l}\begin{array}{l}\text { Coastal } \\
\text { A zone areas } \\
\text { with potential for } \\
\text { breaking wave }\end{array} \\
\text { and erosion during base } \\
\text { flood }\end{array}$ & $\begin{array}{l}\begin{array}{l}\text { A zone areas } \\
\text { with shallow } \\
\text { flooding only }\end{array} \\
\text { where potential for } \\
\text { breaking waves and } \\
\text { erosion is low }\end{array}$ \\
\hline Design & $\begin{array}{l}\text { Building and its foundation } \\
\text { must be designed, } \\
\text { constructed, and anchored to } \\
\text { prevent floatation, collapse, } \\
\text { and lateral movement due to } \\
\text { simultaneous wind and water } \\
\text { loads. }\end{array}$ & $\begin{array}{l}\text { Building must be designed, } \\
\text { constructed, and anchored } \\
\text { to prevent flotation, } \\
\text { collapse, and lateral } \\
\text { movement resulting from } \\
\text { hydrodynamic and } \\
\text { hydrostatic loads, including } \\
\text { the effects of buoyancy. } \\
\text { Recommendation: } \\
\text { Follow V-zone requirement }\end{array}$ & $\begin{array}{l}\text { Building must be } \\
\text { designed, constructed, } \\
\text { and anchored to prevent } \\
\text { flotation, collapse, and } \\
\text { lateral movement } \\
\text { resulting from } \\
\text { hydrodynamic and } \\
\text { hydrostatic loads, } \\
\text { including the effects of } \\
\text { buoyancy. }\end{array}$ \\
\hline $\begin{array}{l}\text { Free of } \\
\text { Obstructions }\end{array}$ & $\begin{array}{l}\text { The space below the lowest } \\
\text { floor must be free of } \\
\text { obstructions (e.g. free of any } \\
\text { building element, equipment, } \\
\text { or other fixed objects that can } \\
\text { transfer flood loads to the } \\
\text { foundation, or that can cause } \\
\text { floodwaters or waves to be } \\
\text { deflected into the building) or } \\
\text { must be constructed with } \\
\text { non-supporting breakaway } \\
\text { walls, open lattice, or insect } \\
\text { screening. }\end{array}$ & $\begin{array}{l}\text { None } \\
\text { Recommendation: } \\
\text { Follow V-zone requirement }\end{array}$ & None \\
\hline Materials & $\begin{array}{l}\text { Structural and non-structural } \\
\text { building materials at or below } \\
\text { Base Flood Elevation (BFE) } \\
\text { must be flood-resistant. }\end{array}$ & $\begin{array}{l}\text { Structural and non- } \\
\text { structural building } \\
\text { materials at or below BFE } \\
\text { must be flood-resistant. }\end{array}$ & $\begin{array}{l}\text { Structural and non- } \\
\text { structural building } \\
\text { materials at or below } \\
\text { BFE must be flood- } \\
\text { resistant. }\end{array}$ \\
\hline Siting & $\begin{array}{l}\text { All new construction shall be } \\
\text { landward of mean high tide. } \\
\text { Recommendation: } \\
\text { Site new construction } \\
\text { landward of long-term erosion } \\
\text { setback and landward of area } \\
\text { subject to erosion during } 100- \\
\text { year costal flood event. }\end{array}$ & $\begin{array}{l}\text { Encroachments into } \\
\text { floodways designated } \\
\text { along rivers and streams } \\
\text { are prohibited unless they } \\
\text { will cause no increase in } \\
\text { flood stage. } \\
\text { Recommendation: } \\
\text { Follow the V-zone } \\
\text { requirement }\end{array}$ & $\begin{array}{l}\text { Encroachments into } \\
\text { floodways designated } \\
\text { along rivers and streams } \\
\text { are prohibited unless } \\
\text { they will cause no } \\
\text { increase in flood stage. }\end{array}$ \\
\hline
\end{tabular}

Table. FEMA General Construction Requirements 


\section{STATE RESTRICTIONS}

Establishing building codes and revising zoning restrictions are land use planning decisions often considered to be the province of local governments, but some problems, such as addressing long-term vulnerability to coastal hazards, have been increasingly viewed as beyond the scope or capacity of local governments, and states can play a significant role in adopting or strengthening land use and development management plans. ${ }^{307}$ See Chapter 1 on Coastal Management Plans for a more in-depth discussion on the influence state plans can exert on local governments and for an assessment of the Maine Shoreland Zoning Act that required local governments to adopt minimum standards for local coastal zoning.

\section{Maine Coastal Sand Dune Rules $\$ \S \S$}

The Maine Coastal Sand Dune Rules, as the name would imply, govern private and public development on the Maine sand dune system. ${ }^{308}$ Section 6 governs the standards for building and re-building on frontal dunes. Excerpts are provided on the following page.

Section 6 of the Maine Coastal Sand Dune Rules has several notable features. First, sections 6 (B) and (C) prohibit new construction "on or seaward of a frontal dune" and in a V-Zone. Section (C) even limits vertical additions to a building in a V-zone, recognizing that winds and waves are threats to buildings in the $V$ zone as well as floods. Sections (D-F) all include rebuilding standards that limit the size of a replacement building to the dimensions of the previous building. These provisions both work to limit the intensity of use in these areas. They prevent, for example, a developer from acquiring a single-family home property and turning it into a higher-density subdivision. This limits the number of people and amount of property at risk in these regions.

Sections (D-F) also incorporate Maine's setback requirement into the rebuilding restrictions. The new building "must be moved back from the beach to the extent practicable, as determined by the department given setback requirements and site limitations." This helps to avoid repetitive losses by moving buildings away from the most vulnerable coastline. (See Chapter 2 on Setbacks and Easements for more information.)

The most interesting provision is Section 6 (E), which states "A building may not be reconstructed more than once...if the building is located in a V-Zone." This is the most direct effort to limit repetitive losses and it does so by the straightforward means of recognizing that $V$ zones are vulnerable areas likely to be exposed to repeated hazards. These regulations have had the positive outcome of limiting repetitive losses to new construction in the V-zone. ${ }^{309}$

\footnotetext{
$\S \S \S$ For more on the history of the Maine Coastal Sand Dune Rules and how the Rules restrict the construction of coastal armoring, see Chapter 3 on Preventing Armoring.
} 


\section{Maine SAND DUne Rules}

\section{$\S$ 6. Standards for Frontal Dune Projects}

(B) New construction in frontal dunes. A new structure or addition to an existing structure may not be constructed on or seaward of a frontal dune...

(C) Construction in V-Zone. No new structure or addition to an existing structure, including but not limited to vertical additions may be constructed in a V-zone except for ramps and elevators providing handicap access as outlined in Section $6(B)(3)$, open fences and fire escapes constructed on existing buildings or similar structures as required by local fire codes. A building in a V-Zone may only be reconstructed under Section 6(D) if it was involuntarily severely damaged by fire or some other force majeure not to include wave action from an ocean storm. If only a portion of a building is located in a V-Zone, this section applies to the portion of the building that is in the V-Zone.

(D) Reconstruction of buildings not severely damaged by wave action from an ocean storm. Reconstruction of a building not severely damaged by wave action from an ocean storm must meet the following standards.

(1) The building must be moved back from the beach to the extent practicable, as determined by the department given setback requirements and site limitations...

(2) The area and dimensions of the footprint of the building may not exceed the area and dimensions of the footprint of the previously existing building when the building is reconstructed in the same location. The area of the footprint of the building may not exceed the area of the footprint of the previously existing building if the building is moved farther back from the beach.

$\cdots$

(E) Reconstruction of buildings severely damaged by wave action from an ocean storm ... A building may not be reconstructed more than once in accordance with this section if the building is located in a V-Zone. A building located outside a V-Zone may not be reconstructed more than once without complying with the standards outlined in Section 6(F). [Similar restrictions are imposed to those in § 6(D).]

(F) Reconstruction of buildings severely damaged by wave action from an ocean storm that have already been reconstructed once. Buildings in the frontal dune, but outside of the VZone that are severely damaged by wave action from an ocean storm must meet the following minimization and mitigation standards. [Imposes set back, lot coverage restrictions, and mitigation requirements.] 
Maine's tidally influenced shoreline is both the longest and the most privately owned (97\%) along the U.S. East Coast. ${ }^{310}$ One of the main challenges facing Maine coastal planners is therefore how to influence private landowners to implement risk management policies on their private property. When the Maine Sand Dune Rules were introduced, and during their early implementation, state officials conducted a strong public education effort to raise awareness about the reality of sea level rise and beach erosion and the dangers posed to private property. ${ }^{311}$

The Maine Sand Dune Rules allow variances to the straightforward prohibitions established in Section 6. ${ }^{312}$ Specifically, Section 9 allows for the Department of Environmental Protection (DEP), which administers the act, to grant variances and allow construction in $V$ zones and on or seaward of frontal dunes. Variances are on occasion a necessary reality to balance the strict prohibition against rebuilding with a recognition of private property rights (and a need to avoid takings claims - see below).

One further rebuilding provision of the Maine Sand Dune Rules that is worth note is Section 10 , which provides that any structure that encroaches on a coastal wetland for six months or more must be removed.

\section{Maine SAND Dune Rules}

$\S 10$. Standard conditions of permits

\section{(A) Shoreline recession}

If the shoreline recedes such that a coastal wetland, as defined under 38 M.R.S.A. $\S 480-$ $B(2)$, extends to any part of the structure, including support posts, but excluding seawalls, for a period of six months or more, then the approved structure along with appurtenant facilities must be removed and the site must be restored to natural conditions within one year.

Note: This contingency is applied to all projects that receive a permit for construction in the coastal sand dune system and is appended to the property deed and passed on to subsequent property owners when a title is transferred. [Note is part of DEP Rules]

\section{Takings and the Maine Sand Dune Rules}

In the seminal case Lucas v. South Carolina Coastal Council, the U.S. Supreme Court determined that a regulatory action could be a taking, requiring government to compensate the private landowner, unless the regulation advanced a legitimate government interest and did not deprive the property owner of all "reasonable investment-backed expectations" in the property. ${ }^{313}$

Maine has had relatively little outcry surrounding the Sand Dune Rules, in part because the state has not been challenged, to date, with a major disaster affecting large portions of the 
population. There have been a significant number of court challenges to the Sand Dune Rules, but the Maine Supreme Court has continued to support the constitutionality of the rules and their enforcement. The Court's decision in Wyer in $\mathbf{2 0 0 0}$ was particularly notable because the court found that uses that were not economically optimal, such as picnics, parking, and recreation, could be considered as benefits to the property owner even if the property owner was denied the right to build permanent structures thus preventing the takings claim. This case highlights the uncertainty that surrounds takings issues.

\section{Wyer v Board of Environmental Protection, 747 A.2d 192 (Me. 2000)}

William Wyler was denied a variance to build on a coastal property. The Maine Supreme Court ruled that denial of the variance was not a government taking because the denial of the variance had not "rendered the property substantially useless and stripped it of all practical value." The court reasoned that "because of the property's close proximity to Higgins Beach in Scarborough, the [trial] court properly considered the uses of the property for parking, picnics, barbeques and other recreational uses as beneficial uses available to Wyer despite the restrictive regulation." Moreover, the court "had competent evidence to support its findings that the property had a value of $\$ 100,000$ before the Department of Environmental Protection denied the variance and $\$ 50,000$ after it denied the variance."

\section{LOCAL RESTRICTIONS}

Local governments can also implement zoning and building code regulations that restrict property owners' ability to construct buildings in the coastal area and to rebuild damaged buildings after a disaster. This can be achieved through zoning acts, ${ }^{314}$ building codes, or other planning ordinances.

\section{Example - City of Waveland, Mississippi}

The state legislature in Mississippi delegated the authority to local governments to adopt regulations designed to promote the public health, safety, and general welfare. ${ }^{315}$ Drawing on this authority, the City of Waveland, MS, adopted a series of floodplain management regulations that included building restrictions, including Flood Damage Prevention Ordinance Number $342 .{ }^{316}$ Ordinance 342 clearly states that "It is the purpose of this ordinance to promote the public health, safety and general welfare and to minimize public and private losses due to flood conditions in specific areas." ${ }^{137}$ This specific statement of purpose draws on health and safety, which are broadly recognized as legitimate government interests that can be pursued even if they place some burdens on private landowners. 


\section{City of Waveland, MS Flood Damage Prevention Ordinance Number 342:}

Located within areas of special flood hazard areas established in Article 3, Section B are Coastal High Hazard Areas, designated as Zones V1-V30, VE and/or V. These areas have special flood hazards associated with high velocity waters from surges and, therefore, in addition to meeting all provisions in this ordinance, the following provisions shall also apply:

1. All new construction and substantial improvements in Zones V1-V30 and VE (V if the base flood elevation is available) shall be elevated on pilings and columns so that:

a. The bottom of the lowest horizontal structural member of the lowest floor (excluding the pilings or columns) is elevated one foot or more above the base flood level; and

b. The pile or column foundation and structure attached thereto is anchored to resist flotation, collapse and lateral movement due to the effects of wind and water loads acting simultaneously on all building components. Wind and water loading values shall each have a one percent chance of being equaled or exceeded in any given year (100-year mean recurrence interval).

2. A registered professional engineer or architect shall develop or review the structural design, specifications and plans for the construction, and shall certify that the design and methods of construction to be used are in accordance with accepted standards of practice for meeting the provisions of Section $\mathrm{G}(\mathrm{I})(\mathrm{a})$ and (b).

4. All new construction shall be located landward of the reach of mean high tide.

5. Provide that all new construction and substantial improvements have the space below the lowest floor either free of obstruction or constructed with non-supporting breakaway walls, open wood latticework, or insect screening intended to collapse under wind and water loads without causing collapse, displacement, or other structural damage to the elevated portion of the building or supporting foundation system. For the purpose of this section, a breakaway wall shall have a design safe loading resistance of not less than 10 and no more than 20 pounds per square foot.... Use of breakaway walls which exceed a design safe loading resistance of 20 pounds per square foot (either by design or when so required by local codes) may be permitted only if a registered professional engineer or architect certifies that the designs proposed meet the following conditions:

a. Breakaway wall collapse shall result from water load less than that which would occur during the base flood; and, coastal building sites for landscaping and site grading as long as the fill does not interfere with the free passage of floodwaters and debris underneath the building or cause changes in flow direction during coastal storms such that will cause additional damage to buildings on the site or to any adjacent buildings. ...[continued] 


\section{Rebuilding Restrictions Post-Sandy in New York and New Jersey}

In the aftermath of Hurricane Sandy, which struck the east coast October 2012, rebuilding restrictions were enforced in New York and New Jersey. A tangled mix of federal, state, and local requirements confused homeowners and illustrated the importance of pre-planning and coordination.

In New York City, FEMA released provisional updated flood maps to serve as a guide for where and how homes and businesses could be safely rebuilt. These were the first updates to those maps to be issued since 1983, and the new maps placed thousands of buildings into Zone $A$ and $V$ areas. ${ }^{318}$ In order to build according to the FEMA regulations, structures would need to be elevated above the Advisory Base Flood Elevation (ABFE), a requirement that would conflict with city height restrictions for buildings. ${ }^{319}$ In response, the Bloomberg administration issued an executive order suspending certain zoning restrictions, such as building heights, in order to remove obstacles for property owners to rebuild in conformance with the new federal restrictions. ${ }^{320}$

\section{Zoning Changes}

Local governments can limit damage in coastal areas by limiting the intensity of use in vulnerable locations. Overlay zoning and downzoning are two possible methods to modify existing zoning laws.

\section{Overlay Zoning}

Overlay zoning works in concert with existing zoning laws to apply an additional layer of regulation in special areas, such as coastal hazard areas. Overlays can set development densities, building regulations, setback requirements, or water-dependent use requirements. ${ }^{321}$

Greenwich, Connecticut, using the authorization of the Connecticut Coastal Management Act, ${ }^{322}$ has implemented a Coastal Overlay Zone whose purpose is to "limit the potential impact of coastal flooding and erosion patterns on coastal development so as to minimize damage to and destruction of life and property and to reduce the necessity of public expenditure to protect future development from such hazards." ${ }^{323}$ Development projects within the zone require a Coastal Site Plan detailing the project's water-dependent activity and a "description of proposed methods to mitigate adverse effects on coastal resources." 324

Del Mar, California, has enacted a Floodplain Overlay Zone specifically to address coastal flooding:

The purpose of the regulations of this Chapter is to promote the public health, safety and general welfare by ensuring that new development, as defined herein, is appropriately sited and constructed so as to avoid hazards to those 
who will occupy the development; and to avoid damage or hazards to the surrounding area. These regulations are also intended to ensure that development within the Floodplain Overlay Zone will not obstruct flood flow; will be designed to reduce the need for construction of flood control facilities that would be required if unregulated development were to occur; and to minimize the cost of flood insurance to Del Mar residents. ${ }^{325}$

The regulations applied to the Floodplain Overlay Zone include building restrictions (such as elevations and location of electrical equipment), siting requirements (no new building seaward of the mean high tide line), and information disclosures (including insurance requirements). ${ }^{326}$

\section{Downzoning}

Downzoning reduces the use intensity of an existing zone by reducing densities or permitted uses in the area. ${ }^{327}$ Existing structures and permitted uses within a down-zoned area are allowed to remain, but if a building is damaged or destroyed, its reconstruction must conform to the most current zoning and building requirements, which are likely to be more stringent. ${ }^{328}$ Specific down-zoning measures could include changing the classification of a zone, for example from "residential" to "conservation" or reducing the allowed residential density from three units per acre to one unit per acre.

State authorization for downzoning may be required. The Connecticut Coastal Management Act, for example, explicitly authorizes municipalities to use tools such as downzoning to regulate development in coastal areas. ${ }^{329}$ This authority was not available under the previous Zoning Enabling Act. ${ }^{330}$

\section{Uninhabitability}

Coastal storms, sea level rise, and beach erosion all have the potential to threaten the stability and safety of coastal homes. In some cases, homes will be uninhabitable due to safety concerns about the stability of foundations or the function of sewage and water connections. In Sandwich, Massachusetts, following storms in winter 2013, several homes were declared uninhabitable after winds and waves washed away foundations. ${ }^{331}$ In Pacifica, California, the 1997-1998 El Nino storms accelerated erosion on coastal cliffs and left homes exposed and in some cases projecting over the edge of the cliff. Seven houses had to be demolished in one neighborhood. ${ }^{332}$

In Isla Vista, California, in 2004, five large apartment complexes, worth almost \$20 million were condemned due to cliff erosion that had made the homes uninhabitable. ${ }^{333}$ The houses were built primarily in the 1960s and 1970s, when the area still had a beach (reportedly large enough to play volleyball on) and the threat seemed distant. ${ }^{334}$ Today, the problem persists, in part because Isla Vista is home to a large student population from the nearby University of California Santa Barbara, and apartment complexes along the threatened cliffs command a 
premium rent. Reportedly, the college students themselves seem unaware of the threat or rely on information from their landlords, which can be at odds with that provided by the county. ${ }^{335}$

Building restrictions on coastal homes should be carefully monitored in order to detect when coastal erosion has made properties unlivable. This should also be coupled with a setback requirement so that homeowners do not simply patch the damage following each storm but when feasible relocate the property inland to prevent repeated future damage.
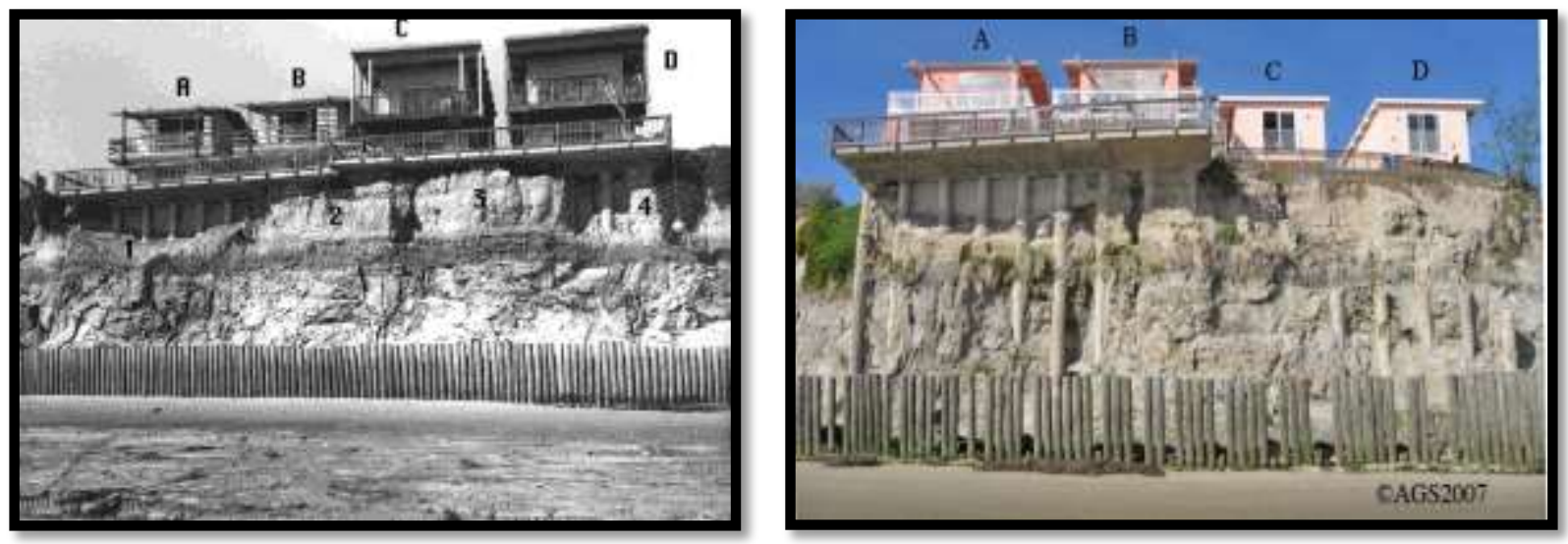

Isla Vista in 1987 (left) and 2007 (right). Notice how two homes have had to cut back away from the cliff. Photo: USGS.

\section{LESSONS LEARNED AND RECOMMENDATIONS}

- Implement building restrictions and zoning decisions as soon as possible. These actions will only affect structures built after the regulations are put in place, so to avoid having buildings grandfathered in under old regulations, these need to be put in place promptly.

- Draft building and rebuilding requirements with future hazards in mind as well as current hazards. Sea level rise and climate change are likely to exacerbate the risks faced by coastal communities. Buildings in some $A$ zones will soon have to face $V$ zone-like hazards, so regulations should require buildings in $A$ zones to comply with all $V$ zone requirements. Consider implementing regulations not only for the 1 in 100 year flood but also for the 1 in 500 year flood.

- Prohibit repetitive repairs. Limit the number of times a building may be severely damaged by coastal events before it has to be removed entirely. This is an excellent way to prevent the costly public expenditures that will be required by repetitive losses along the coasts. Stating these requirements explicitly in advance of a disaster will put the community on notice. 
- Educate the public about the risks associated with coastal living and the ways in which building restrictions address those risks. Conduct education campaigns when and where possibly. Partner with scientists and policy experts from universities, environmental groups, and other advocacy organizations.

- Place the burden of proof on the private property owner. This will both require the property owner to educate him or herself about the risks facing the property and will reduce the resource burdens on government agencies.

- Coordinate zoning, building restrictions, setbacks, easements and other coastal management tools within a coherent coastal management plan to ensure that all tools are working towards complementary goals.

- Coordinate federal, state, and local building and rebuilding requirements to the extent possible. Conduct this review and coordination before a disaster so that property owners will be able to begin repairs as soon as possible after a disaster.

\section{FURTHER READING}

FEMA, Help after a Disaster, Applicant's Guide to the Individuals \& Households Program (July 2008), http://www.fema.gov/pdf/assistance/process/help after disaster english.pdf.

FEMA, Know the Facts about the NFIP before Repairing or Rebuilding (February 2006), http://www.fema.gov/news-release/2006/02/23/know-facts-about-nfip-repairing-orrebuilding.

Jessica Grannis, Julia Wyman, Meagan Singer, Jena Shoaf, Colin Lynch, Coastal Management in the Face of Rising Seas: Legal Strategies for Connecticut 5 Sea Grant Law \& Policy Journal 59, 72 (2012).

New York City, Information about Rebuilding after Hurricane Sandy, http://www.nyc.gov/html/om/pdf/2013/eo qa 013013.pdf.

Jay M. Zitter, Annotation, Validity of Provisions for Amortization of Nonconforming Uses, 8 A.L.R.5th 391, 412-22 (1992). 


\section{REFERENCES}

${ }^{285}$ See, e.g., Lucas v. South Carolina Coastal Council 505 U.S. 1003 (1992) (holding that the local government's nobuild regulation resulted in a takings violation); First English Evangelical Lutheran Church v. Los Angeles County, 482 U.S. 304 (1987) (holding that the temporary ordinance prohibiting rebuilding after a flood violated constituted a taking).

${ }^{286}$ For example, New Jersey prohibits rebuilding in the most vulnerable areas of the coast of New Jersey that experienced damage due to Hurricane Sandy, available at http://newjersey.sierraclub.org/PressReleases/0448.asp (last visited Aug. 9, 2013).

${ }^{287}$ For discussion on prior non-conforming uses, see Christopher Serkin, Existing uses and the Limits of Land Use Regulations, 84 NeW York UNIVERSITY LAW REVIEW 1222 (2009); Terry Rice, Survey: Zoning and Land Use, 50 SyRACUSE LAW REVIEW 917 (2000).

${ }^{288}$ See, e.g., Joseph A. Katarincic, Elimination of Non-Conforming Uses, Buildings, and Structures by AmortizationConcept Versus Law, 2 DUQuesne LAW ReVIEW 1 (1963).

${ }^{289}$ For example, in Connecticut the Zoning Enabling Act (ZEA) limits the ability of local governments to phase out non-conforming uses. See Jessica Grannis, Julia Wyman, Meagan Singer, Jena Shoaf, Colin Lynch, Coastal Management in the Face of Rising Seas: Legal Strategies for Connecticut, 5 SEA GRANT LAW AND Policy JouRnaL 59, 77 (2012).

${ }^{290}$ See Serkin, supra note 287.

291 FEMA, Know the Facts About the NFIP Before Repairing or Rebuilding, http://www.fema.gov/newsrelease/2006/02/23/know-facts-about-nfip-repairing-or-rebuilding (last visited 30, July 2013).

${ }^{292}$ National Flood Insurance Program § 60.3 (a)(3)(iii), 42 U.S.C. §§ 4011-4032 (2012).

${ }^{293}$ Flood Disaster Protection Act of $1973 \S 202($ a), 42 U.S.C. $\S 4012$ (2012). See also FEMA, Know the Facts, supra note 291.

${ }^{294}$ For example the FEMA maps for New York were from 1983 before Sandy. See Mayoral Press Release, Mayor Bloomberg Announces New Measures to Allow Home and Property Owners Rebuilding After Hurricane Sandy to Meet Updated Flood Standards, Jan. 31, 2013, PR-044-13, http://www.nyc.gov/portal/site/nycgov/menuitem.c0935b9a57bb4ef3daf2f1c701c789a0/index.jsp?pagelD=mayor press release\&catID=1194\&doc name=http\%3A\%2F\%2Fwww.nyc.gov\%2Fhtml\%2Fom\%2Fhtml\%2F2013a\%2Fpro 44-13.html\&cc=unused1978\&rc=1194\&ndi=1 (last visited Aug. 15, 2013) (stating that New York FEMA maps had last been updated in 1983); Jill Colvin, FEMA Re-Drawing City's Flood Zone After Superstorm Sandy, DNAINFo, Dec. 6, 2012, http://www.dnainfo.com/new-york/20121206/new-york-city/fema-redrawing-citys-flood-zone-aftersuperstorm-sandy (last visited Aug. 15, 2013). See also, Nancy Cohen, Vermont to FEMA: Put Our Flooding on Your Maps, NPR, Apr. 28, 2013, http://m.npr.org/story/179561106 (saying that latest flood maps were "decades old").

${ }^{295}$ Theodoric Meyer, As Need For New Flood Map Rises, Congress and Obama Cut Funding, Scientific American, May 27, 2013, http://www.scientificamerican.com/article.cfm?id=new-fema-flood-maps-needed-but-fundingslashed (last visited Aug. 15, 2013).

${ }^{296}$ Ernest B. Abbott, Floods, Flood Insurance, Litigation, Politics-and Catastrophe: The National Flood Insurance Program, 1 Sea GRANt LaW \& Policy JouRnal, 140 (2008).

297 To learn more about Special Flood Hazard Areas, see FEMA, Special Flood Hazard Areas, http://www.fema.gov/floodplain-management/special-flood-hazard-area (last visited Aug. 15, 2013).

${ }^{298}$ FEMA, Permit for Floodplain Development, http://www.fema.gov/national-flood-insurance-program-2/permitfloodplain-development (last visited Aug. 15, 2013). 
${ }^{299}$ U.S. Army Corps of Engineers $\S 404,40$ CFR 230 (1994) (permits for wetlands filling; permits for work in navigable waterways U.S. Coast Guard; permits for bridges and causeways that may affect navigation). U.S. Fish and Wildlife Service-consultations required under Endangered Species Act of 1973, §§ 7, 10, 16 U.S.C. §§ 15311544.

${ }^{300}$ National Flood Insurance Program $\S 60.3$ (a)(4)(iii).

${ }^{301} / d$.

302 FEMA National Flood Insurance Program, The 50\% Rule, FEMA Region VII, Apr. 21, 1997, available at http://dnr.ne.gov/floodplain/flood/Desk Reference/Tab-03-Regional Guidance/50 Rule.pdf (Accessed 30, July 2013).

${ }^{303}$ See, e.g., New Jersey State Uniform Construction Code, N.J.A.C. 5:23; State of New Jersey Department of Environmental Protection Division of Land Use Regulation, Frequently Asked Land Use Permitting Questions Post Superstorm Sandy, Updated July 2, 2013, http://www.nj.gov/dep/landuse/SandyFAQ.html\#a11 (in Detailed Information Flooding Question 4) (last visited Aug. 15, 2013).

${ }^{304}$ FEMA Technical Fact Sheet No. 2, Home Builder's Guide to Coastal Construction: Summary of Coastal Construction Requirements and Recommendations (2005), available at (http://www. mscoastalmapping.com/PDF/hgcc fact02.pdf).

${ }^{305} / d$., at 1.

${ }^{306}$ Flood Evaluation Determinations § 42 U.S.C. § 4104 (2012).

${ }^{307}$ See, e.g., Philip Berke and Steven French, The Influence of State Planning Mandates on Local Plan Quality, 13 JoURNAL OF PLANNING EdUCATION AND RESEARCH 237 (1994), available at http://jpe.sagepub.com/content/13/4/237.

${ }^{308}$ Natural Resources Protection Act, Maine Revised Statutes Annotated $§ 355$ (2004).

${ }^{309}$ See Julia Knisel, Hazardous Beach-System Development in Maine and Some Outcomes of the Sand Dune (Thesis in Masters of Science in Marine Policy, University of Maine, 2003), available at http://digitalcommons.library.umaine.edu/etd/154 (stating most paid insurance claims in Maine as of 2003 had occurred on properties grandfathered in from before the Rules were implemented).

${ }^{310}$ See Joseph T. Kelley et. al., Managing Beaches in the Northeast: The History of Maine's Sand Dune Rules, Proceedings from $13^{\text {Th }}$ Biennial Coastal Zone Conference, Baltimore, MD, July 13-17, 2003 (2003) at 1, Citing P.L. Ringold AND J. Clark, THe CoAStal AlmanaC (W.H. Freeman and Co., San Francisco, CA, 1980).

${ }^{311}$ See Lisa A. St. Amand, Sea Level Rise and Coastal Wetlands: Opportunities for a Peaceful Migration, 19 BostoN College Environmental Affairs LaW Review 1, 8 (1991), http://lawdigitalcommons.bc.edu/ealr/vol19/iss1/2.

${ }^{312}$ See Knisel, supra note 309, at 58.

${ }^{313}$ Lucas v. South Carolina Coastal Council, 505 U.S. 1003, 1034 (1992).

${ }^{314}$ This concept of incorporating adaptation goals into the design of zoning districts was initially proposed by Tom Ankersen, Director of the Conservation Clinic at the University of Florida Levin College of Law. See Thomas T. Ankersen, et al., Presentation to the Charlotte Harbor National Estuary Program, Comprehensive Plan Policies, Land Development Regulations, and a Parcel-Specific Implementation Strategy to Address Sea Level Rise Impacts in Florida (May 27, 2010), available at http://www.flseagrant.org/coastalplanning/wp-_content/uploads/2012/03/sea_level_rise_Cons.Clinic_2010_v.2.pdf.

${ }^{315}$ Mississippi Code Annotated, Title 17, Chapter 1 (1972).

316 City of Waveland, Mississippi, Flood Damage Prevention Ordinance 342, Art. 5 §A (2009) http://www.georgetownclimate.org/sites/default/files/CITY\%200F\%20WAVELAND\%20ordinance\%20342.pdf.

${ }^{317}$ Id.

${ }^{318}$ See Mayor Bloomberg Announces New Measures to Allow Home and Property Owners Rebuilding After Hurricane Sandy to Meet Updated Flood Standards, Jan. 31, 2013, supra note 294; FEMA Region II Coastal Analysis 
and Mapping, View Best Available Flood Hazard Data for New Jersey and New York, http://www.region2coastal.com/bestdata (last visited Aug. 15, 2013); Annie Karni, Feds find big jump in floodprone New Yorkers, CRAIN'S NEW YORK BUSINESS, June 10, 2013 http://www.crainsnewyork.com/article/20130610/NEWS/130619983 (last visited Aug. 15, 2013) (stating that new maps covered twice as many buildings as the previous maps).

${ }^{319}$ See Mayor Bloomberg Announces New Measures to Allow Home and Property Owners Rebuilding After Hurricane Sandy to Meet Updated Flood Standards, Jan. 31, 2013, supra note 294; see also Matt Chaban, City Waives Some Rules to Speed Rebuilding, CRAIN'S NEW YORK BUSINESS, Jan. 31, 2013, www.crainsnewyork.com/article/20130131/REAL ESTATE/130139975 (last visited Aug. 15, 2013).

${ }^{320}$ Id.

${ }^{321}$ See Brian Ambrette, Municipal Zoning Options for Adaptation to Sea Level Rise in Connecticut, The Nature Conservancy White Papers, http://www.scrcog.org/documents/hazard mitigation/background material/TNC CT Municipal Zoning Options \%20for\%20SLR.pdf (last visited Aug. 15, 2013).

322 CGS §§ 22a-90 - 22a-112, inclusive (1980); Greenwich Municipal Code, Use Regulations, § 6-111(A) Coastal Overlay Zone.

323 Greenwich Municipal Code, Use Regulations, § 6-111 Coastal Overlay Zone, available at http://www.greenwichct.org/upload/medialibrary/23f/pzRegsDivision09.pdf (page 41).

${ }^{324}$ Id. § 6-111(C)C(5).

325 Del Mar, CA, Municipal Code, Chapter 30.56, available at http://www.delmar.ca.us/Government/Municipal\%20Code/Chapter_3056.pdf.

${ }^{326} / d$.

${ }^{327}$ See generally, Jessica Grannis, Julia Wyman, Meagan Singer, Jena Shoaf, Colin Lynch, Coastal Management in the Face of Rising Seas: Legal Strategies for Connecticut 5 SEA GRANT LAW \& Policy JouRnal 59, 72 (2012).

${ }^{328}$ See generally, 82 American Jurisprudence $2^{\text {nd }}$ Edition, Zoning and Planning $§ 178$ (1976); see also Jay M. Zitter, Annotation, Validity of Provisions for Amortization of Nonconforming Uses, 8 A.L.R.5th 391, $412-22$ (1992); Osborne Reynolds, Jr., The Reasonableness of Amortization Periods for Nonconforming Uses - Balancing the Private Interest and the Public Welfare, 34 WASHINGTON UNIVERSITY JOURNAL OF URBAN AND CONTEMPORARY LAW 99 (1988).

${ }^{329}$ CONN. GEN. STAT. §22a---103(c); see also Grannis et al., Coastal Management in the Face of Rising Seas, supra note 327.

${ }^{330} / d$.

${ }^{331}$ See e.g., George Brennan and Doug Fraser, Storm erosion threatens houses, dunes, CAPE COD TIMES, Feb. 13, 2013, http://www.capecodonline.com/apps/pbcs.dll/article?AID=/20130213/NEWS/302130323/-1/rss02 (last visited Aug. 15, 2013).

332 USGS, 1997-1998 El Nino Coastal Monitoring Program, http://walrus.wr.usgs.gov/elnino/coastal/pacifica.html (last visited Aug. 15, 2013) (stating that 7 of the 9 monitored homes were demolished).

333 See Curtis Brainard, Retreat or Retrench?, The New York Times, June 9, 2005, http://www.nytimes.com/2005/06/09/garden/09erode.html?pagewanted=all.

${ }^{334}$ See id.; Robert Norris, Thirty-Four Years of Observations at Isla Vista, Cliff Erosion, 21 COAST AND OCEAN (2005), http://www.coastandocean.org/spring summer2005/pages/five.html

${ }^{335}$ See Brainard, supra note 333; Ben Afshar, Erosion a serious problem many students in Isla Vista are unaware of, THE CHANnels, Apr. 19, 2011, http://www.thechannels.org/news/2011/04/19/erosion-a-serious-problem-manystudents-in-isla-vista-are-unaware-of. 


\section{CHAPTER 5}

\section{ACQUiSITION: EASEMENTS, EMINENT Domain, AND BuYOUTS}

Acquisition programs are the most commonly used tool to reduce community vulnerability to littoral and riverine flooding. They are also the most expensive options, as the government must use public funds to purchase the lands. Buyout programs, in particular, may have longterm economic costs in terms of lost tax revenue if landowners relocate outside the tax district. However, acquisition programs also give the government the greatest degree of control and have additional benefits as they not only remove the threat of repeated flood damage to infrastructure but also reduce public expenditures on risk mitigation and enable the creation of natural buffers that benefit the broader community.

\section{Fee Simple or Easement}

Acquisition programs are used by government agencies to acquire an interest in private property. Some acquisition programs acquire a conservation easement, in which a landowner donates or is compensated for development rights on the property. Conservation easements are most effective when the landowner desires to maintain the current level of development on the property or where lots are large enough such that the government can obtain an easement on a portion of the lot and still permit development to occur in other portions. In areas of heavy development and small lot size, acquisition programs more often purchase a fee simple, or title, to the property, and the government therefore becomes the titled landowner. Although there are other types of acquisition, these two are the main examples used for managed retreat and will be discussed in further detail.

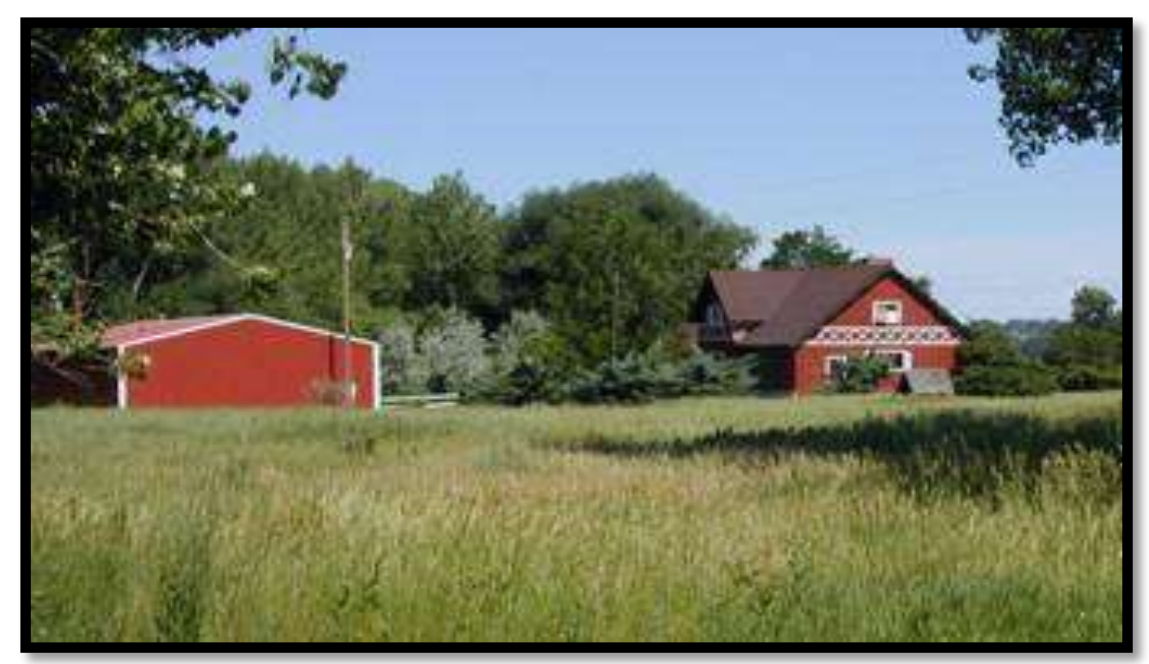

Conservation easements on small-acreage rural properties in Boulder, $\mathrm{CO}$, act as buffers from encroaching development and help retain agricultural traditions in the area. Photo: City of Boulder. 


\section{CONSERVATION EASEMENTS}

A conservation easement is a voluntary legal agreement between a landowner and an organization that restricts specific activities on a piece of property in order to protect conservation values such as ecosystems, wildlife habitat, biodiversity, or open space. Conservation easements have been used in every state and protect millions of acres of land. Easements may be held by federal, state, or local government agencies as well as local and regional nonprofit organizations. Numerous federal agencies hold conservation easements throughout the United States: as of 2004, the National Park Service alone held easements on 253,348 acres. ${ }^{336}$ In Pennsylvania, 6,276 conservation easements held by federal, state, local, private, and nonprofit organizations cover 495,952 acres and maintain the land for environmental purposes or as open space for farming, forests, and recreation. ${ }^{337}$ Conservation easements are binding on all future owners for the duration of the easement, which is often in perpetuity, although conservation easements can be negotiated for shorter periods of time, as will be discussed.

\section{Compensation}

Conservation easements can be established through a voluntary donation of development rights by the landowner or through purchase of the development rights by the government (or other organization). ${ }^{338}$ Purchased development rights (PDRs) are attractive to landowners because they provide direct financial compensation. The Coastal and Estuarine Land Conservation Program (CELCP) administered by NOAA provides a limited amount of funding (roughly \$3 million annually) to help protect coastal and estuarine areas that have significant conservation value and are threatened by conversion to another use. ${ }^{339}$ In addition to direct purchase, there are other incentives for landowners to pursue conservation easements including tax credit programs and estate tax benefits.

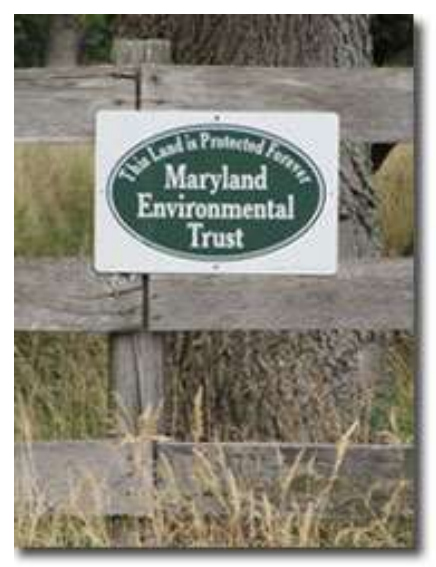

Photo courtesy of the Maryland Department of Natural Resources.

\section{$\underline{\text { Tax Credits }}$}

The federal government has offered a tax deduction for easement donations since $1964,{ }^{340}$ and in 1983, North Carolina became the first state to establish a state tax credit program for conservation easements. In 1999, Colorado, Connecticut, Delaware, and Virginia enacted their own state programs, and several other states have followed since. However, for landowners with little income subject to state taxation, a tax credit provides little real incentive for a landowner to reduce the value of his real property by donating his development rights. In order to address that concern, Colorado amended its tax credit to make the credit transferable: the landowner can sell her credit to a third party at a discounted value. ${ }^{341}$ 
In 2002, Virginia also established transferability for its conservation tax credits, ${ }^{342}$ and its transferable credit program is the largest in dollar value of property conserved. ${ }^{343}$ Virginia's tax credit program operates statewide, and in only nine years it has generated over 2,000 individual land conservation donations, protecting over 434,000 acres of land. The appraised value of the protected land is over $\$ 2.2$ billion and represents more than $\$ 970$ million in tax credits. ${ }^{344}$ Virginia caps the amount of credit an easement can generate: only $40 \%$ of the value of the easement may be claimed, and up to $\$ 100,000$ per year for the year of the sale and the ten subsequent tax years. In states where such credit programs exist, free markets have arisen to exchange credits and brokers have begun to specialize in conservation easement credit transfers. ${ }^{345}$

\section{Estate Taxes}

Conservation easements reduce the value of land to which the owner retains title and may therefore be useful in reducing estate taxes. This can be of particular concern to families to want to keep land intact but who are faced with high estate taxes due to the development potential of their land and the therefore high value. A conservation easement can help in these ways:

1. Reduce the value of the land. Estate taxes will be lower because the value of the land will be reduced by the value of the potential development.

2. Estate exclusion. The federal tax code provides an estate tax incentive for donated conservation easements. Up to an additional $40 \%$ of the value of the land (subject to a $\$ 500,000$ cap) may be excluded from the estate when the landowner dies. ${ }^{346}$ This is in addition to the reduction in land value mentioned above.

\section{Land Use}

Conservation easements can be used to prevent development and retain land parcels in their natural state. However, easements can also be tailored to prevent only specific types of development or activities. Conservation easements in rural areas are often constructed to permit agriculture, timber extraction, and recreation. ${ }^{347}$ As a result, conservation easements are most often used in less developed areas where they can be designed to maintain current levels of development. As easements are voluntary and often un-compensated, these involve the support of the local community, who wish to maintain the natural state of the area either to maintain traditional livelihoods or to support local tourism.

What is important to remember is that easements are negotiated agreements and can be tailored to specific situations. In the context of coastal development, it is not necessary for land to be entirely abandoned. It could be limited to season or small dwellings that would not be expensive to rebuild in the case of a storm but would still permit a landowner to enjoy the beach access of his or her property. 
The timing of the easements is also a negotiable term. Most conservation easements run in perpetuity with the property. However, it is possible to negotiate easements for shorter periods of time. The Fish and Wildlife Service enters into short-term conservation easements (10 to 30 years) in order to enable wildlife restoration without removing all future development potential of an area. ${ }^{348}$ These shorter conservation easements can build into permanent agreements once trust has been established and the benefits proven. Similarly, short easements could be used in coastal areas to prevent immediate development of areas that are believed to be vulnerable to sea level rise. As sea levels rise and the dangers of the coast become more established, landowners may become increasingly willing to enter into more permanent managed retreat arrangements.

A sample National Park Service conservation easement is included in the Appendix. See lowa Flood Case Study, Wapello Levee District for an example of conservation easements in an acquisition post-disaster scenario.

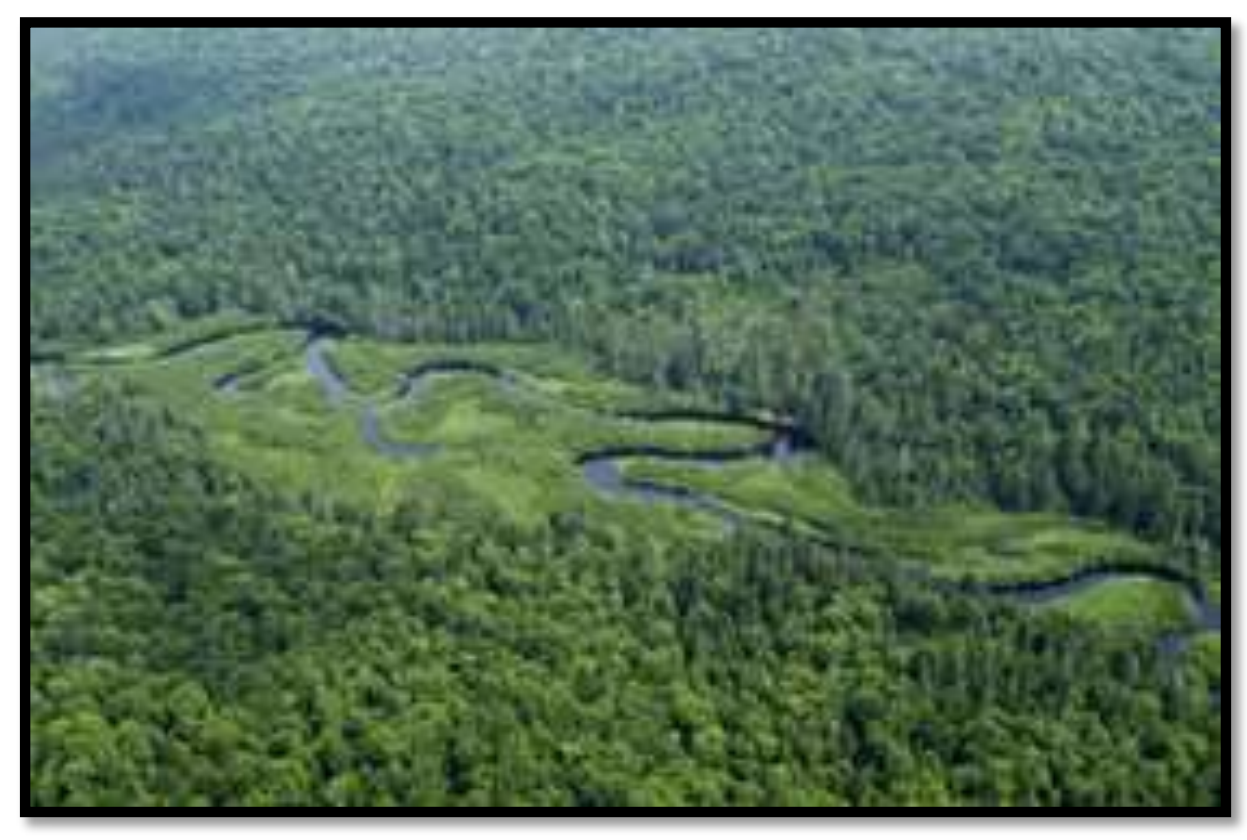

This 110,000-acre conservation easement in the New York Adirondack Mountains allows continued sustainable forestry and opens some of the land to public recreation. Photo: New York Department of Environmental Conservation. 


\section{A note on Transferable Development Rights (TDRs)}

TDRs (sometimes called Transferable Development Credits; TDCs) are a marketbased mechanism intended to guide dense development toward preferred, urban areas while preserving rural areas and open spaces. TDRs have not been used in a managed retreat context, but they have the potential to effectively address coastal hazards by shifting development away from vulnerable shores. ${ }^{349}$

The legal premise of TDRs is that the right to develop land is a separate and severable right from ownership of the land. ${ }^{350}$ Developers in areas where development is desirable can

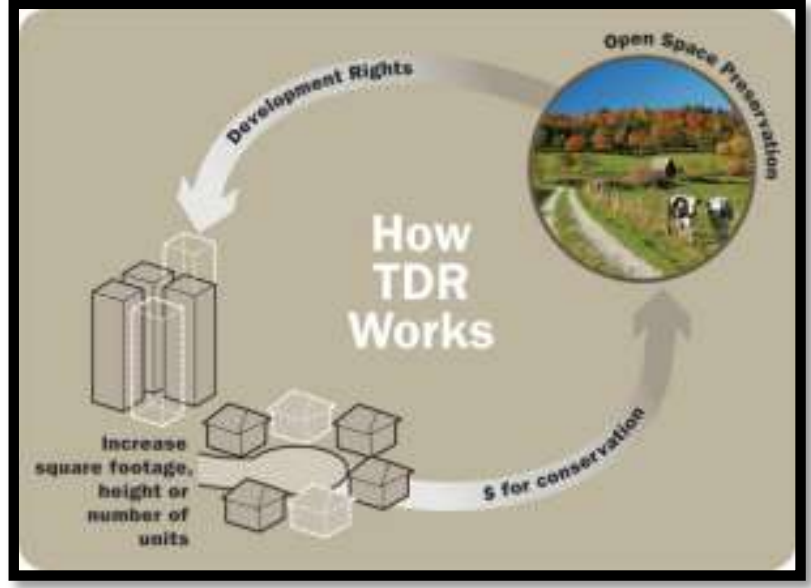

Photo: King County, WA purchase TDRs from landowners were development is not allowed and use those rights on their own properties (see image below). The land that sold its development rights then has that note recorded in its deed as a conservation easement or a restrictive covenant to prevent future development. $^{351}$

TDR programs have not yet been employed to mitigate hazards caused by sea level rise, but they have been used to achieve a wide range of land use goals including the protection of agricultural lands, preservation of wildlife habitats and coastal resources, and control of development densities in areas with limited infrastructure or public services. ${ }^{352}$ In these contexts, TDR has achieved widespread implementation throughout the United States. According to one estimate from 2012, there are 239 TDR programs in 35 states. $^{353}$

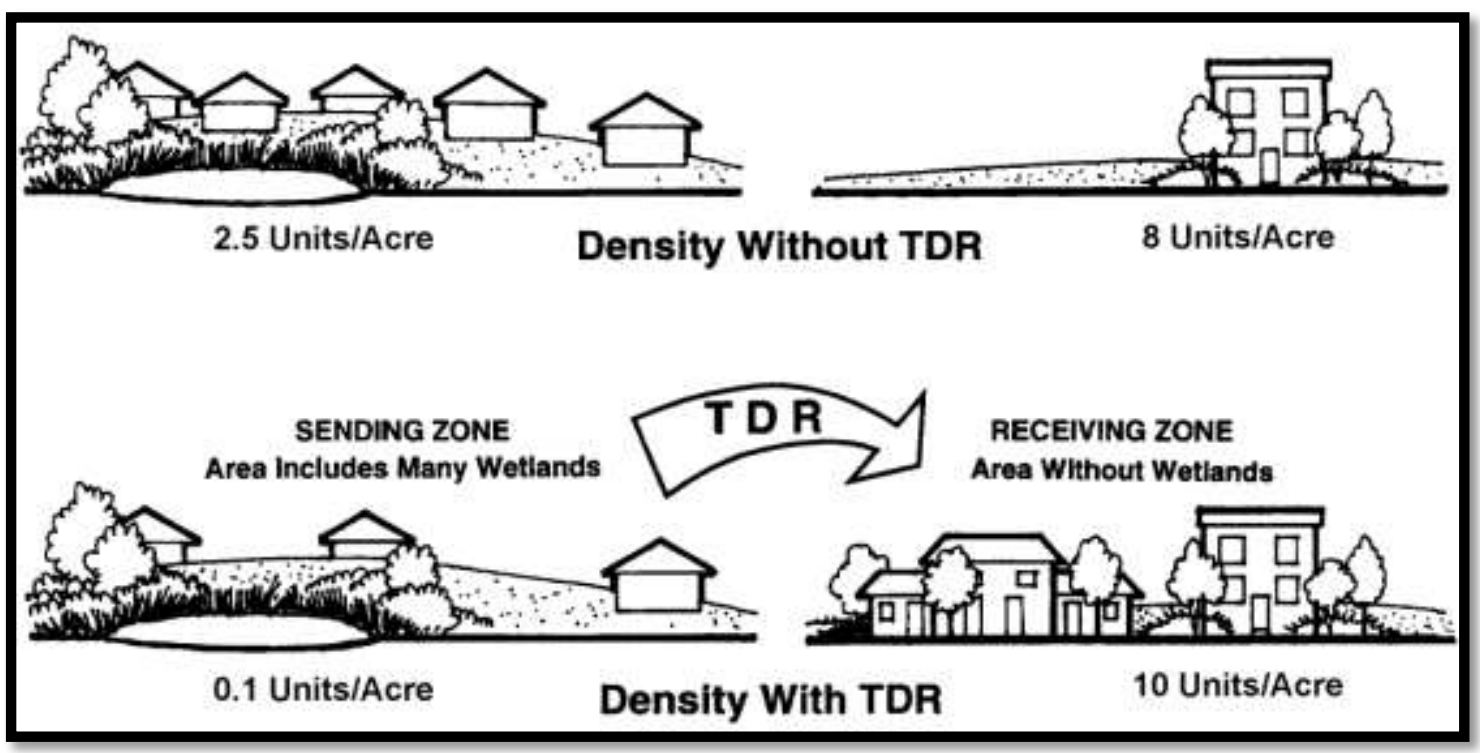

Michigan Department of Environmental Quality 
In a traditional, non-market based TDR program, the zoning authority limits the allowed development density in a high density area (such as an urban neighborhood). The authority then requires developers who want to build in the area to pay a fee, and the revenue is used to purchase development rights or conservation easements in rural, low density areas. ${ }^{354}$ This kind of traditional model, however, was costly for public administrators and it resulted in inefficient land allocation. In short, these programs were often failures. ${ }^{355}$

However, it is also possible to create a market for TDRs, similar to the market established for the sale of tax credits generated by conservation easements discussed above. Sometimes such TDR programs are called Marketable Development Right (MDR) programs. ${ }^{356}$ In theory, the program is simple: authorities designate areas in which development is completely or partially curtailed (where TDRs are severed from the land) and areas in which development is promoted (where TDRs can be purchased and attached to the land). ${ }^{357}$ These are termed sending sites and receiving sites, respectively. ${ }^{358}$ TDRs are allocated to owners in the sending sites, who can then sell their severed development rights to developers in the receiving sites or use them themselves in the receiving site.

\section{Identifying Sending and Receiving Sites}

Identifying a suitable receiving site is particularly important for the success of the program. $^{359}$ The receiving site should be considered suitable both from the developers' perspective (as in desirable for building and having a market) and from the public authority's point of view. The public authority might consider the existing transportation infrastructure, public services, employment, schools, etc. ${ }^{360}$ Often these spaces are both within the jurisdiction of just one authority, but TDR programs can be structured to work across jurisdictions, such as from a county to an incorporated city. ${ }^{361}$

\section{Shaping Political Perception}

Although TDR programs do not actually inhibit overall development, they can create a perception of economic loss in the sending sites. ${ }^{362}$ The Rural Lands Stewardship Program in Collier County, Florida was able to address political resistance and preserve 31,400 acres by separating new-town receiving sites from existing development. ${ }^{363}$ The new receiving sites were therefore seen as encouraging new development rather than expanding on existing sites and were seen as an economic boon for the region. Another approach, adopted in Calvert County in Maryland, is to establish a number of possible receiving zones including a low density

rural receiving area. ${ }^{364}$ Again, this can change the perception to one of guided economic development rather than a prohibition of development. 


\section{Buyout Programs}

\section{Acquisition v. Buyout}

Acquisition is a general term that covers a variety of programs in which the government purchases land. Buyout programs are a specific type of acquisition program in which the government uses public funds to purchase title of privately held lands, demolishes existing structures on the land, and maintains the land in an undeveloped state for public use in perpetuity. Buyout programs can be conducted without the consent of the landowners by using eminent domain to acquire the lands, but most often buyout programs are conducted with voluntary sales from landowners who have recently experienced one of the disasters to which they are vulnerable. Buyout programs can be structured to provide financial incentives for owners who are uncertain about selling their property.

\section{Buyout Program Goals}

Buyout programs are designed to achieve several goals:

- Reduce the exposure of people to dangerous conditions.

- Reduce future disaster response costs by removing buildings and structures from the path of flooding.

- Restore natural buffers such as wetlands to a natural state in order to reduce future flooding levels.

- Eliminate the need to maintain and repair flood control structures.

- Reduce future flood insurance payments. ${ }^{365}$

- Assist homeowners by providing them with financial means to move from the floodplains. ${ }^{366}$

- Eliminate emergency response, garbage collection and other municipal services in the area.

- Provide open space for the community.

According to FEMA, "voluntary buyouts in the 30 top repetitive loss communities cost $\$ 1$ for every $\$ 2$ saved in future insurance claims," an estimate which does not include money saved on actions "such as local flood fighting, evacuation, and rescue and recovery expenses that will not be incurred in the future." 367

One critical advantage provided by a buyout program is the opportunity to use the acquired space to create a natural buffer. A natural buffer, such as a restored wetland or park space, is 


\section{Advantages of Floodplains}

\section{Floodwater Storage}

Floodplains in their natural state are designed to hold floodwaters. A one-acre floodplain can store 1.5 million gallons of floodwaters that would otherwise damage nearby structures.

\section{Pollution removal}

Wetlands slowly drain excess floodwaters back into rivers, oceans, and groundwater. In the process, wetlands filter out pollutants like sediment, excess nutrients and some harmful chemicals.

\section{Urban Park Space}

Restored floodplains are wellsuited to serve as parklands with greenway trails for recreation. Increased green space in urban areas can also combat the urban heat island effect and reduce the severity of extreme heat events.

\section{Wildlife Preservation}

Floodplains often contain wetlands and marshy areas that provide feeding and breeding grounds for many types of wildlife. an area that will soak up storm and flood waters and thereby reduce or even prevent flooding further inland. In order to maximize the potential of the natural buffer, the buyout needs to acquire a continuous swatch of land along the coastline or river that can be turned into a buffer zone, and the government needs to maintain the land in an undeveloped space (or use it as parkland or other low maintenance and low infrastructure recreational space).

Developing public parklands provides not only intangible social benefits but also a potential economic investment. Development is often considered the best use of land, as it raises property values, but development also requires expenditures and provision of public services, which may be more expensive than the increase in property value. $^{368}$ Parks themselves may actually increase the value of existing developed properties. Homes near green spaces have a higher value - potentially a full third higher - than their more distant neighbors. ${ }^{369}$ These benefits are present even in dense cities with high property values.

Acquisition strategies that permit redevelopment of acquired land parcels fail to take advantage of these important benefits. This is one of the reasons that federal buyout programs require local and state governments to not redevelop acquired lands.

\section{Funding a Buyout Program}

A buyout program can be entirely funded through state or local funds, but most often buyout programs occur after a nationally recognized disaster and use a combination of federal and state funds. The Federal Emergency Management Agency (FEMA) administers programs to help with buyouts under the Stafford Disaster Act, and the Department of Housing and Urban Development (HUD) administers another 
through Community Development Block Grants (CDBG) (see inset).

Federal funds generally cover $75 \%$ of the expenses. The remaining $\mathbf{2 5 \%}$ must come from state and local resources, which can be a financial burden for communities recovering from a disaster. In some cases, HUD CDBG funding can be used to cover the $25 \%$ cost. In order to raise the necessary revenue, some states and municipalities have imposed property taxes or enacted new sales taxes, the proceeds of which flow into a fund specifically designated for buyouts. In all cases, it is important to recognize that funds used for a buyout are being spent to mitigate future disasters and their associated costs and should therefore be considered an investment in the community.

\section{Federal Funding - Section 404 Stafford Act}

The Robert T. Stafford Disaster Relief and Emergency Assistance Act authorizes the President to issue major disaster and emergency declarations. This allows federal agencies to provide assistance to states overwhelmed by adverse events. Section 404 of the Act is known as the Hazard Mitigation Grant Program (HMGP) and is one of the primary funding sources for large buyout programs.

\section{Eligibility}

HMGP funding is only available to communities in a presidentially declared disaster area. Under the Disaster Mitigation Act of 2000, local communities must have a FEMA-approved Local Mitigation Plan in place in order to receive funding. Individual homeowners may not apply to the program. The program is intended to fund state and locally administered programs on behalf of homeowners.

\section{FEMA Funding}

- The Hazard Mitigation Grant Program (HMGP) provides a percentage of total disaster assistance funds for mitigation measures to be implemented during the immediate recovery after a disaster.

- The Flood Mitigation Assistance (FMA) Program provides funding to states and communities for measures that reduce or eliminate the long-term risk of flood damage to buildings, manufactured homes and other structures insured under the National Flood Insurance Program (NFIP).

- The Pre-Disaster Mitigation (PDM) Program provides competitive grants to states, tribal governments and local governments for cost-effective hazard mitigation that complements a comprehensive mitigation program.

\section{HUD Funding}

- Community Block Development Grants (CBDG) provide flexible funding to help cities, counties, and States recover from presidentially declared disasters, especially in low-income areas. Funds can be used for a variety of activities, including acquisition of damaged properties. 


\section{Steps in the HMGP}

Applying for funding through the HMGP is a multistep process that requires coordination of local, state, and federal officials.

1. State officials determine priorities for disaster response and identify restrictions on flooding financial assistance;

2. Local officials prepare and collect buyout applications from homeowners whose properties were severely damaged or destroyed;

3. Local officials submit applications to the state, who reviews the applications and submits to FEMA; ${ }^{370}$

4. FEMA reviews the applications and determines whether the application: a) satisfies FEMA's rules, b) is environmentally sound, ${ }^{371}$ and $c$ ) is a cost-effective use of funds.

5. Upon approval, local officials begin purchasing land and demolishing existing structures.

\section{$\underline{\text { HMGP Requirements }}$}

The HMGP has particular requirements and conditions that must be met in order to secure funding. Among the most important are:

- The buyout must be a cost-effective measure that will substantially reduce the risk of future flooding damage; ${ }^{372}$

- Properties must be acquired at pre-disaster prices;

- Acquired lands must be maintained as open public space, used for recreational purposes, or used for wetlands management practices. ${ }^{373}$ This may require local officials to deed restrict all property using FEMA's Model Deed Restrictions (available on the FEMA website) and submit a sample deed restriction to FEMA; ${ }^{374}$

- No new structure may be built upon the acquired property, aside from small recreational facilities (picnic coverings, rest rooms) that are functionally related to open space, and flood control structures; ${ }^{375}$

- No future disaster assistance funds may be applied for or received from the federal government with respect to this property; and

- Buyouts must be voluntary in order to use HMGP funds. ${ }^{376}$

$\underline{\text { HMGP Administration }}$ 
A state must demonstrate to FEMA that it has the ability to manage the program, an approved mitigation plan, and a demonstrated commitment to mitigation activities ${ }^{377}$ in order to administer the buyout program. State administration provides the state with greater control and direction, especially the power to review and approval local mitigation plans. However, it also requires state resources that might be scarce during a disaster recovery period.

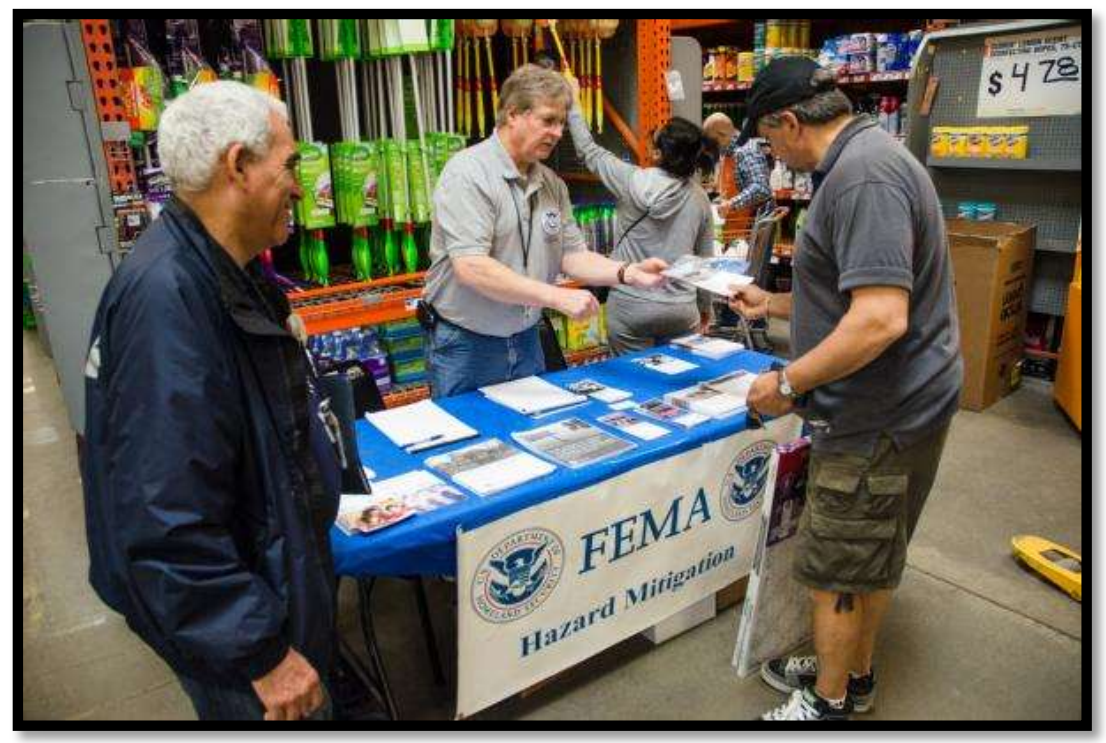

Bay Shore, N.Y., 2013 FEMA Mitigation Outreach Teams visit Lowe's and Home Depot stores in the New York area to offer information on Flood Insurance Rate Maps, repairs and rebuilding. Photo credit: K.C. Wilsey FEMA. 


\section{Other HMGP Projects:}

Although the focus in this handbook is on managed retreat, it should be noted that HMGP funds may be used for a variety of projects that will reduce or eliminate losses in future disasters. Projects must provide a long-term solution to a problem, for example, permanent elevation of a home to reduce the risk of flood damages as opposed to buying sandbags and pumps to fight the flood. In addition, a project's potential savings must be more than the cost of implementing the project.

Examples of projects include, but are not limited to:

- Acquisition of real property for willing sellers and demolition or relocation of buildings to convert the property to open space use

- Retrofitting structures and facilities to minimize damages from high winds, earthquake, flood, wildfire, or other natural hazards

- Localized flood control projects designed specifically to protect critical facilities

- Post-disaster building code related activities that support building code officials during the reconstruction process

\section{Relocation}

An essential, but often overlooked, aspect of a successful buyout program is a plan for relocation. Managed retreat often emphasizes movement away from the vulnerable coasts without identifying areas that are available for development. This is true of most of the tools in this handbook but is particularly true of buyout programs where landowners are selling their homes and divesting their entire interest in the land. Having a relocation plan is crucial for maintaining communities, for gaining public support, and for long-term economic development.

Government planners can do one or more things to assist in relocation:

- Identify areas preferred for development;

- Provide a financial incentive for residents to relocate within the city or county; this can be particularly helpful in maintaining the local tax base and preserving the larger community. For example, in the aftermath of Hurricane Sandy, New York Governor Andrew M. Cuomo proposed a buyout plan that would pay owners an additional five percent above full market value if they relocated within the same county; ${ }^{378}$

- Build new housing developments to replace the demolished homes (see Grand Forks Case Study) where practicable; new housing developments should be similarly structured and 
priced as the demolished homes (e.g., replace single family homes with single family homes, not with apartment buildings); this can help maintain neighborhoods if they move together;

- Relocate the community as a whole to a new location (see Soldiers Grove inset below); in this approach the plan is to physically relocate the community as a block to a new location; buildings may be relocated or built new but in a similar pattern to the old neighborhood if suitable land is available.

\section{GRAND FORKS, NORTH DAKOTA - 1996 RED RIVER FLOODS}

\section{Flood}

In 1996, the Red River reached a remarkable 54 feet, 5 feet above the heights predicted for the storm by the National Weather Service. It topped the city dikes in Grand Forks, North Dakota, and East Grand Forks, Minnesota. 90\% of Grand Forks had to be evacuated - the largest evacuation in the United States since Atlanta during the Civil War (50,000 people). 83\% of the homes were damaged, including some that were completely wiped away by the river. 4.5 million acres were flooded by the river, causing more than $\$ 3.5$ billion in damage, the $8^{\text {th }}$ most expensive disaster in U.S. history at the time. A fire broke out in downtown Grand Forks, causing further extensive damage to the city infrastructure.

Steve Gander, President of the East Grand Forks planning-and-zoning commission, said about the rebuilding process: "The river had been our friend for all these years. It had been like an old dog, sleeping comfortably at our feet, and then one day it jumped up and bit us. We had to decide: Do we put it to sleep or try to make amends?" In the aftermath, President Clinton assured the state that the federal government would provide $100 \%$ of the funding through FEMA (instead of the usual $75 \%$ ) and requested $\$ 5.5$ billion from Congress.

\section{Buyouts}

Grand Forks used \$171 million in CDBG funding from HUD to purchase 802 property lots located near the Red River in the center of town. ${ }^{* * *}$ The city physically relocated salvageable homes and destroyed the remaining homes. It turned the empty space into the Greater Grand Forks Greenway (see image on next page), a park 2,200 acres large (more than twice the size of Central Park in New York City) that contained 20 miles of trails, 2 golf courses, boat ramps, campgrounds, ice rinks, basketball and tennis courts, soccer, baseball, and football fields.

One neighborhood, Lincoln Drive Park, was hit particularly hard and many homes were literally swept away in the river bend. Those homes were purchased and that entire curve of

\footnotetext{
${ }^{* * * *}$ East Grand Forks, Minnesota, across the river border, also implemented a buyout program and did so with impressive speed, acquiring 407 properties within 75 days of the disaster declaration and an additional 100 rental properties in a second program.
} 
the river bend became part of the Greenway. This expansion of the green space in the city was viewed by the residents as an opportunity for the city to grow, by promising people the amenities they wanted in an urban environment. This communal space was seen and presented as a one way to revitalize the city while rebuilding.

\section{Relocation}

Using further CDBG funding, Grand Forks entered into a partnership with a private development company to help finance the construction of 180 new homes in an underdeveloped area of Grand Forks. The 180 homes would not replace all 802 lots that were purchased and demolished, but their construction would help relocate some of the people who lost their homes in the buyout. The prices of the single family homes ranged from $\$ 105,000$ to $\$ 147,000$. This was substantially higher than the $\$ 50,000$ to $\$ 80,000$ value of the homes that had been demolished. As a result, even though homeowners had been paid the pre-flood value of their homes, they were not able to purchase the new homes in this area. The homes were actually even more expensive than the average home in Grand Forks at the time (in 1994, $\$ 94,000)$.

The homes were also isolated from the main city and had no local schools. So by February 1999 , only 12 of the 180 homes had been sold. Eventually, the city reduced prices by $\$ 17,500$ and the homes sold. In part, this sale was due to population growth in Grand Forks and the subsequent rise in housing prices.

Today, Grand Forks and East Grand Forks have recovered their populations and are growing, but in the initial recovery, it was difficult for homeowners to find places to live away from the river. That transition time was critical because that was the time when many families decided whether or not to remain in the metropolitan area. 


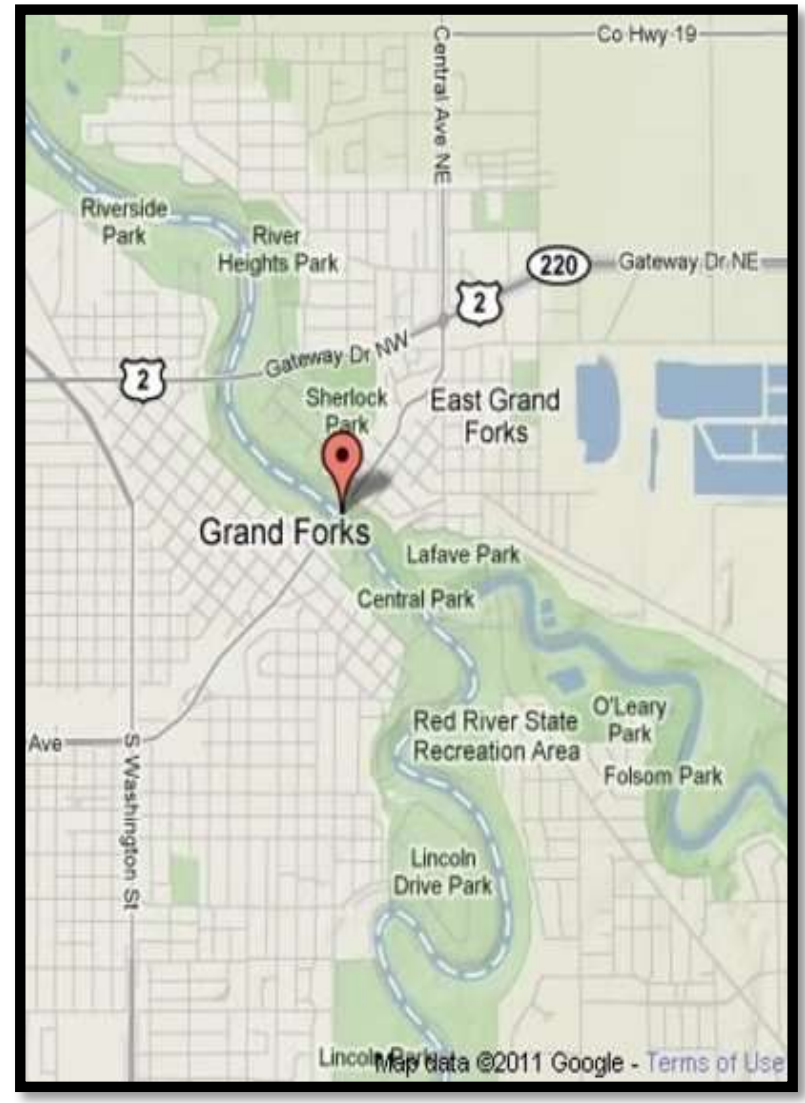

Greater Grand Forks Greenway. Google Maps. 


\title{
COMPLETE RELOCATION \& IMPROVEMENT - SOLDIERS GROVE, WISCONSIN 379
}

\author{
"Soldiers Grove, Wisconsin, pioneered the three-cornered strategy of relocation, renewable \\ energy and sustainable development starting in 1975." - Department of Energy
}

In 1975, following a series of devastating floods from the Kickapoo River, Soldiers Grove residents proposed that, rather than spend $\$ 3.5$ million to build a levee that would protect only $\$ 1$ million worth of property, they use the $\$ 3.5$ million to relocate the town and rebuild on higher ground. Federal assistance amounted to $60 \%$ of the total $\$ 6$ million in costs, with state, local, and private investments making up the balance.

Soldiers Grove used a small planning grant to hire a team of University of Wisconsin specialists to study the feasibility of relocation. After receiving a favorable report, in 1977 the village invested $\$ 90,000$ of its own funds to purchase a site for the new downtown and began to extend utility services.

However, federal agencies were slow to respond, until Soldiers Grove was hit again by a devastating flood in 1978 . Finally, HUD released $\$ 900,000$ in Community Development Block Grants to begin relocation. While federal funding was still uncertain, the state took on a major role.

By 1983, the project was complete. Thirty-six business, three municipal facilities, and 22 homes were relocated closer to U.S. Highway 61, providing a much-needed economic boost to the town. During the relocation, village officials decided to incorporate solar heating in all of the buildings constructed in order to address rising energy costs. They enacted an unprecedented ordinance requiring all new commercial buildings to obtain a least $50 \%$ of their heat from the sun, and another law that prohibited any new structure from blocking sunlight to another building. As a result, Soldiers Grove is often referred to as "Solar Village."

In 2007 and 2008, the area formerly occupied by the town was hit by extreme flooding, destroying the parkland that had been created on the site of the former town. However, the new town avoided the damage. According to locals, this was obvious proof that the relocation had been the right decision. "The recent flood devastation reinforced that we did the right thing. I don't ever want to go through another flood like 1978," said John Young, a local merchant. 


\section{IOWA CASE STUDY - 1993 MISSISSIPPI RIVER FLOODS}

\section{The Flood}

The 1993 Midwest flood was one of the most significant and damaging natural disasters ever to hit the United States at the time. Damages totaled \$15 billion, 50 people died, a thousand levees failed, and thousands of people were evacuated, some for months. ${ }^{380}$ The flood affected people across North Dakota, South Dakota, Nebraska, Kansas, Minnesota, lowa, Missouri, Wisconsin, and Illinois. Nearly 150 major rivers and tributaries were affected, and the flood became one of the

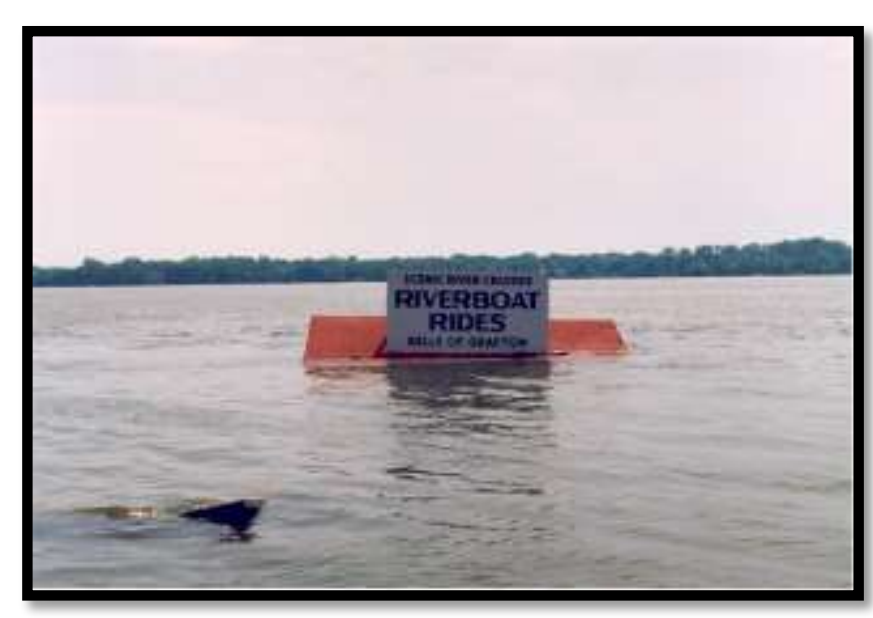

River Rise During the 1993 Floods. Photo: USGS largest and most significant floods ever to occur in the United States. At least 15 million acres of farmland were inundated, some of which were not useable for years after, and 75 towns were totally submerged under flood waters.

A rainy autumn in 1992 was followed by a winter with heavy snowfall, so when heavy rain began to fall in April, the ground soon became saturated, and additional rain ran off into streams and rivers instead of soaking into the ground. ${ }^{381}$ From April 1 to August 31, precipitation in east-lowa reached 48 inches, well above the area's normal annual precipitation of 30-36 inches. And the rain fell nearly continually: many areas experienced rain on 20 days or more in July. ${ }^{382}$

In lowa alone, the floods caused approximately $\$ 3.4$ to $\$ 5.7$ billion dollars in damage and destroyed 25,000 homes. ${ }^{383}$ President Clinton issued two separate disaster declarations for lowa, the second of which covered all ninety-nine lowa counties. ${ }^{384}$

"In Iowa, we must never lose a healthy respect for the force and rhythms of nature. We can work with nature but we can never fully control it. Our closeness to the land gives us a sensitivity to the environment."

- Governor Terry Branstad January 11, 1994

\section{Federal Response}

In response to the unprecedented scope of the destruction, the federal government decided to push the strategy of buying out vulnerable properties located in the floodplain to prevent repeat damage. ${ }^{385}$ As part of its buyout strategy, President Clinton signed the Hazard Mitigation and Relocation Assistance Act of 1993, which propelled more buyouts. $^{386}$ The Act amended Section 404 of the Stafford Act in two ways: 
- It increased the percentage that FEMA may contribute for hazard mitigation measures from fifty percent to seventy-five percent (thereby decreasing the state's required contribution from fifty percent to twenty-five percent).

- It increased the amount that FEMA could contribute to mitigation measures from ten percent of total federal grants made under the Stafford Act to fifteen percent of total grants for a particular major disaster.

\section{lowa Buyouts}

To administer the new Section 404 buyout program, lowa divided itself into ten Housing Recovery Zones based upon a review of the flood damage (see image below). ${ }^{387}$ In each zone, a lead county was appointed and an administrative plan was prepared. The plans laid out the conditions that buyouts must satisfy and the types and amounts of compensation that would be offered to accepted homeowners. The lead county also contracted with a Council of Governments, which managed the program. ${ }^{388}$

Funding for the buyout program came from a variety of sources. First, FEMA provided the vast majority of funds through the Section 404 program. Second, a large portion of the funds came from a variety of other federal sources: the Community Development Block Grant program, the HOME Investment Partnership Program, the Economic Development Administration, and the Department of Agriculture's Emergency Wetlands Reserve Program. ${ }^{389}$ Third, some funds came strictly from state sources: for example, the City of Davenport funded a preexisting acquisition program through a sales tax. ${ }^{390}$

1,013 structures throughout lowa were eventually purchased, which is a small number when compared to the 25,000 homes damaged. ${ }^{391}$ This ratio of damaged homes to purchased

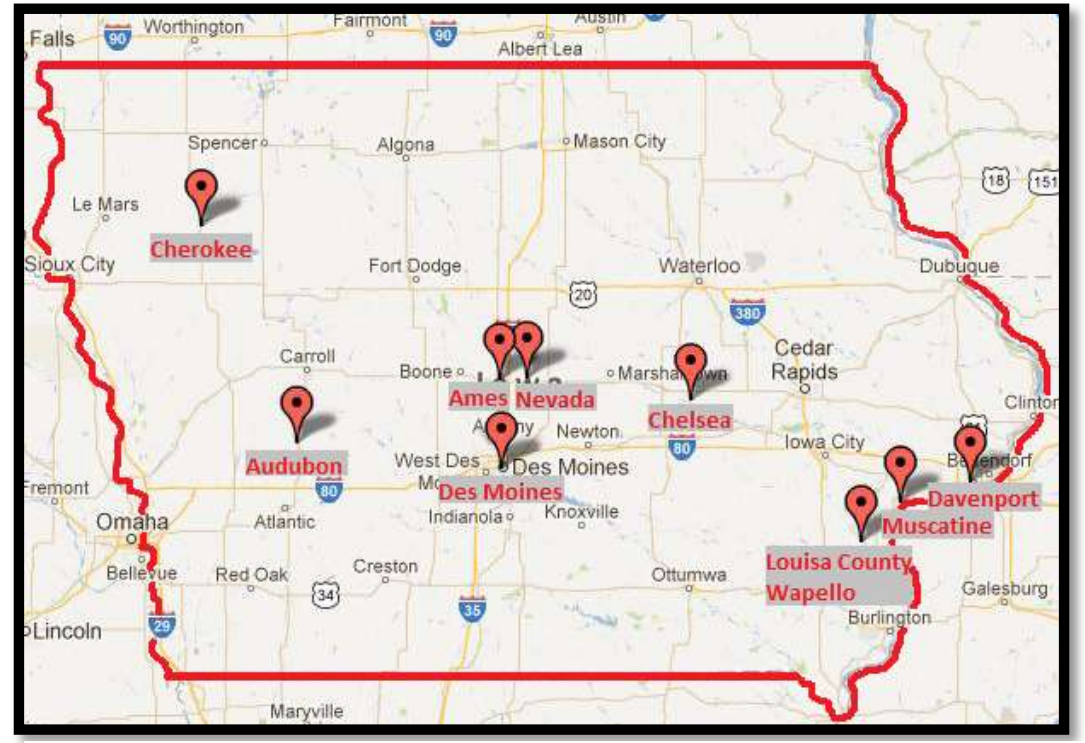

lowa Housing Recovery Zones in the 1993 Flood Recovery. Google Maps. structures shows that governments do not need to buy a large number of affected structures for a program to improve community resilience. As further evidence of the lack of need to buy a large number of structures, consider the experiences of the city of Ames and Louisa County. The city of Ames acquired twenty-eight houses $^{392}$ and is considered a success due to rates of participation and improved resilience of the community. ${ }^{393}$ Meanwhile, Louisa County 
purchased 200 homes, ${ }^{394}$ but its program was much-maligned as an attempt to acquire structures that suffered from a sanitation problem and not to address flooding risks. ${ }^{395}$

Each of the ten Housing Recovery Zones encountered challenges and pursued different tactics that determined the relative success or failure of the program. Three of these zones Ames, Wapello, and Cherokee - will be discussed in further detail below.

\section{Ames Buyout Program}

During the 1993 Great Flood, Squaw Creek and Skunk River flooded half a foot higher than the 100-year flood level (see image on the next page). Residents reported flooding as much as three feet above anything in their memory, and the force of the river washed some home clean off their slab foundations.

After the floods, Ames City decided to implement a buyout strategy for those homes in particularly floodprone neighborhoods. \$2 million was awarded to the city through a combination of FEMA HMGP, CDBG, State, and local resources. lowa Homeland Security and Emergency Management Division administered the funds. $^{396}$

"Our goal as well as that of FEMA is to promote safety. It's best that people are not living in the flood-prone area."

Vanessa Baker Latimer, Housing Coordinator, Ames City's Department of Planning

The program was structured to acquire continuous blocks of land in the most vulnerable areas and to retain population in the city. The buyout focused on homes in the most vulnerable areas of the floodplain and purchased 28 homes. ${ }^{397}$ Property owners were paid the assessed value of their pre-flood land plus ten percent. ${ }^{398}$ If a homeowner agreed to relocate within the city but outside of the floodplain, the homeowner earned an additional $\$ 8,500$ to cover the down payment on a new home, plus moving expenses. ${ }^{399}$

Purchased homes were demolished, and the land became an extension of the existing Stuart Smith Park. The large, undeveloped, open space provides additional storm water management assistance and acts as a flood barrier to help prevent future damage to other homes. The park also contains extensions of trails for biking, jogging, and walking, that improve the town's recreational facilities.

The Ames buyout proved its efficacy when the town received a 100 -year flood in 1996, and again in 2008. And it was put to the test again when the town received a record flood in 2010-a greater than 500-year flood event. In the Arrowsmith Development alone, where six purchased properties were acquired and turned into a natural habitat, FEMA estimates that the acquisition saved $\$ 541,900$ in costs avoided every time it floods. ${ }^{400}$ 


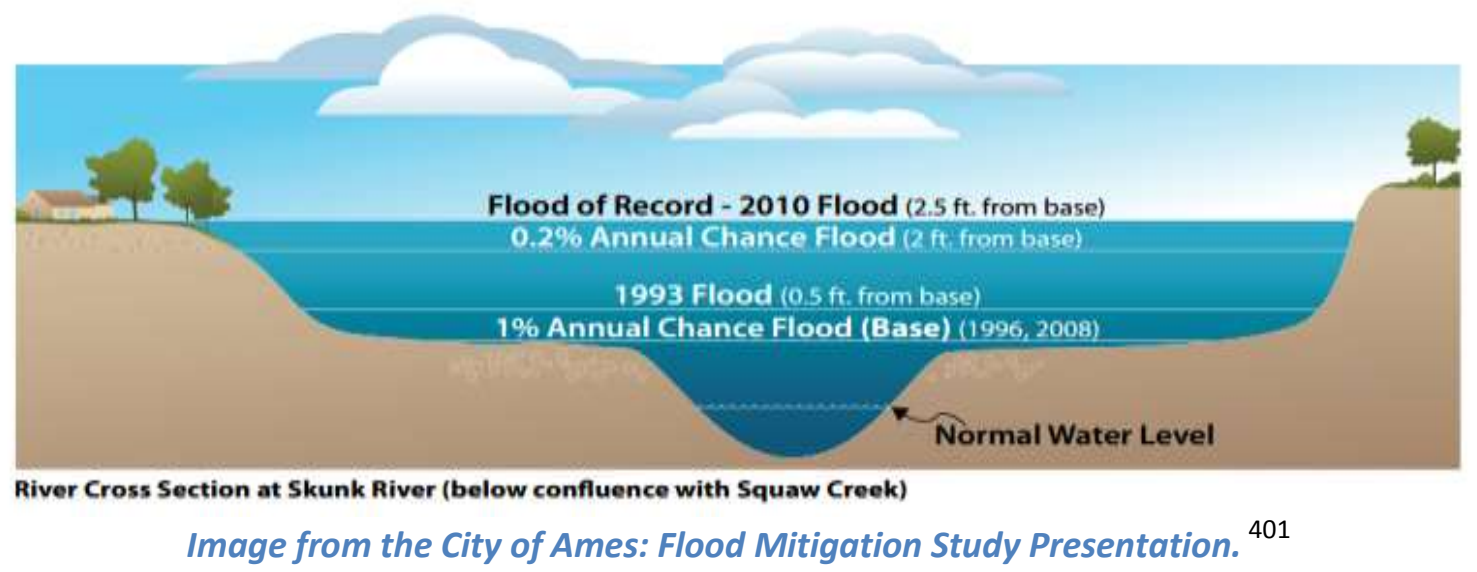

\section{Wapello Buyout Program - Conservation Easements \& Fee Simple Acquisition}

The Wapello Levee District (Levee District 8) buyout program was notable because it developed a novel land-transfer system and engaged government agencies and non-profit organizations in order to execute the effective program. The program was particularly complex because it included a number of agencies and organizations: Natural Resources Conservation Service (administering EWRP), Fish and Wildlife Service (FWS), FEMA, and lowa Natural Heritage Foundation (INHF) coalition.

The Wapello Levee District is an area of the lowa River that was extensively flooded during the 1993 floods. The lands were supposed to be protected by a series of levees, but those levees were overcome during the floods. Repairing the levees would have cost \$3.1 million. Floods of the 1993 levels were generally considered a 1 in 500 year storm, but in this area they were a one in $\mathbf{5 0}$ or one in 100 year event. Repeat failure of the levees would mean repeat flooding on these lands.

Following the 1993 floods, the U.S. Corps of Army Engineers was preparing to rebuild and repair the levees at a cost of \$3.1 million. If the Levee District properties were acquired and demolished, then this levee repair work would become unnecessary, but only if every property in the Levee District was acquired and the Levee District could be dissolved. A working group of various state and federal agencies concluded that the best solution would be to buy all the homes in the levee and drainage district so that the levee district could be statutorily dissolved and the government would not be required to spend the \$3.1 million to repair the levee infrastructure, then or in the future. ${ }^{402}$ The landowners voted to dissolve Levee District $8,{ }^{403}$ and the buyout program proceeded, focused on properties in an area along the lowa River at a point where the river seeks to take a natural bend, in the hope that the buyout would help restore a more natural flow to the river as well as restore other natural features of the landscape. 


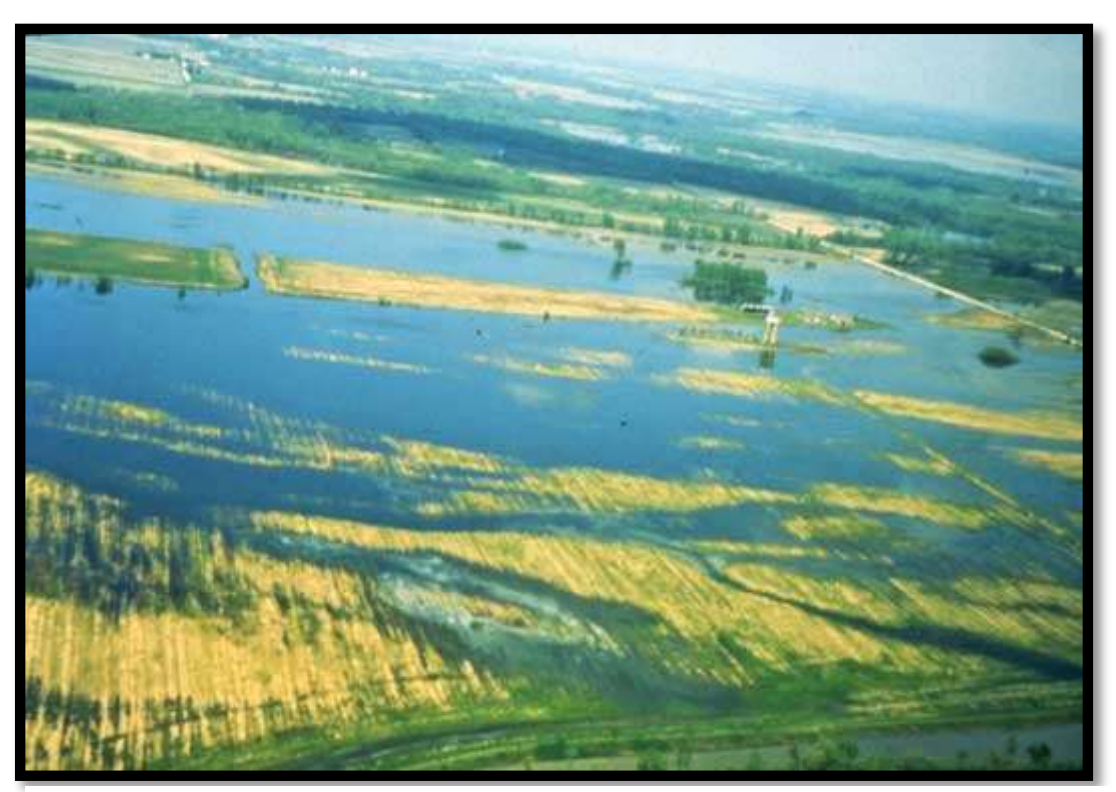

When the levee broke (for the 17th time since its installation in 1910) the Louisa Levee District 8 flooded, including nearby farms. Photo: US FWS

Congress had authorized a special bill, the Emergency Wetlands Reserve Program (EWRP) 1993, specifically for the 1993 Great Floods that authorized the Natural Resources Conservation Service (administering EWRP) and the FWS to purchase conservation easements on vulnerable land and return the property to wetlands. However, landowners in Levee District 8 did not like the program because many of them farmed the land they owned and did not want to maintain ownership of unfarmable lands for which they would be expected to pay real estate taxes and perform maintenance. Rather, they wanted inkind land trades so that they could continue to live and farm on nearby lands. An in-kind land trade with a federal agency, however, was not possible under the EWRP.

In order to overcome this problem, the government working group collaborated with the lowa Natural Heritage Foundation ("INHF"), a nonprofit conservation organization, to actually purchase the land. ${ }^{404}$ The landowners received payment for an EWRP conservation easement on the property (restricting future development to preserve wetlands). Then INHF purchased the lands, using $\$ 500,000$ on loan from FWS to pay for the remaining value of the land. ${ }^{405}$ Then INHF transferred the land to FWS.

Overall the program purchased 2,700 acres, which are today preserved as a green space: the Horseshoe Bend Division of Port Louisa National Wildlife Refuge as a restored river flood plain. $^{406}$ In 2008, the land held 6-15 feet of water during the floods, preventing damage to nearby areas. ${ }^{407}$

A number of factors were critical to the Wapello buyout program's success. First, the federal and state agencies quickly formed their working group, which gave the program momentum. $^{408}$ The working group then maintained good relations through a Memorandum of Agreement, which established that agency members could go up the ladder if they encountered problems working with each other. ${ }^{409}$ Second, INHF's role as the intermediary between landowners and the government agencies was very important: landowners were somewhat hesitant to engage in sales of land with government agencies, so the use of a nonprofit agency facilitated land sales. ${ }^{410}$ 
Third, the purchasers of the land used a formulaic approach in setting the price to be paid, applying the same formula to all landowners in order to determine what price to pay for the land. ${ }^{411}$ This formulaic approach contributed significantly to the success of the program because purchasers didn't need to negotiate prices with each separate landowner ${ }^{412}$ and because it got rid of the incentive for landowners to hold out for a better deal from the INHF. ${ }^{413}$ Fifth, the working group set a short time frame to accept the buyout offer, which limited the ability of landowners to consider their other options. ${ }^{414}$ The total buyout time was 16 months from start to finish, which was extremely rapid considering the number of agencies involved and the extent of the land. This was in some ways expedited because the Corps of Engineers was going to start work on the levee soon and if they started, the whole project would be called off, so landowners had a short decision time.

Horseshoe Bend Division of Port Louisa National Wildlife Refuge. Image: Google Maps

\section{Cherokee Buyout Program}

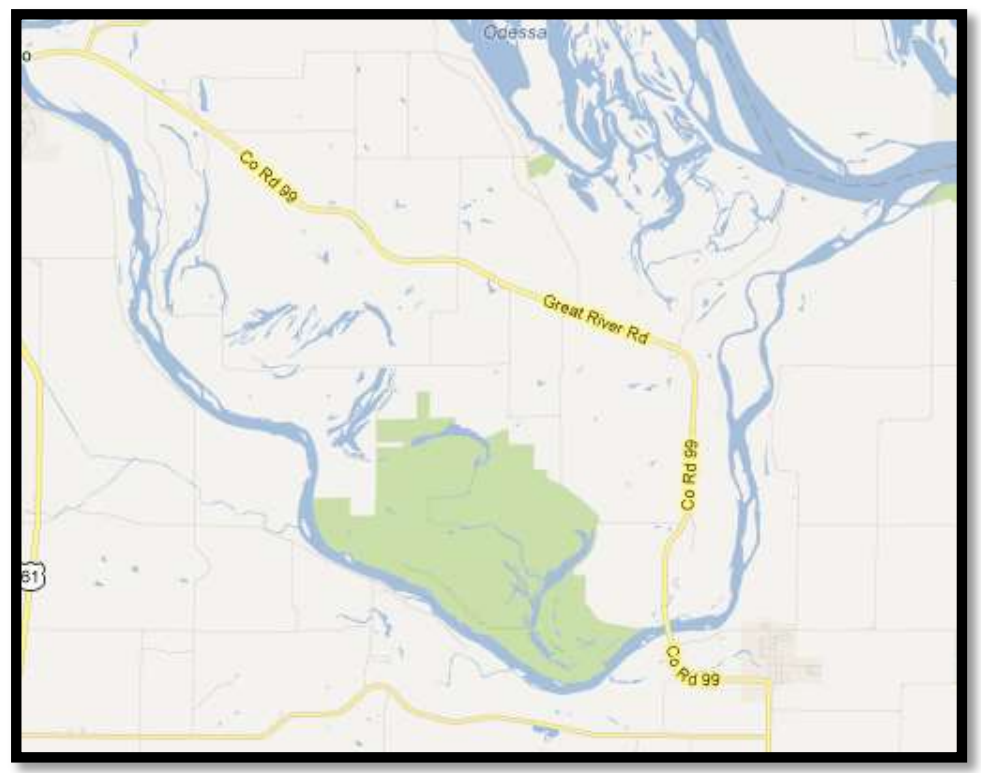

The city of Cherokee organized the largest buyout program in lowa. The end result was a sixty-seven-acre area of land that is primarily green space and is limited to open space uses. ${ }^{415}$ The success of the program was mainly attributed to the extensive community participation. In all, the city of Cherokee's acquisition program in the low-lying Little Sioux River flood area included 187 residential properties of which 156 were purchased and demolished, and 31 homes were relocated to higher ground. ${ }^{416}$

Under the guidance of the National Park Service's Rivers, Trails, and Conservation Assistance Program, the cities of Cherokee, Nevada, and Audubon involved the community in a multi-step process aimed at deciding how to structure their buyout programs. ${ }^{417}$ In each city, the goal was to use the buyout program "to restore the floodplain to a more natural state and to create recreational and other benefits for local residents." ${ }^{118}$ The first step was to appoint a community group to head the entire process. Another step was to hold a public workshop and then prepare a plan. The NPS then reviewed the technical feasibility of the cities' plans and helped them find a funding source for the plans. 
Cherokee organized a local Greenspaces Advisory Committee and held a series of workshops to get people input on how to use the acquired area. ${ }^{419}$ The city and the NPS also recruited students to help with the buyout effort: the NPS trained students on how to conserve open space and manage floodplains, and the students then presented their own ideas on how to use the city's open space to the community. ${ }^{420}$

The city of Cherokee's grassroots approach was also unique because program administrators not only negotiated with buyout targets, but also worked with buyout candidates to ensure that they had adequate opportunities for relocation and replacement housing. Bought-out families could either sell their property and buy or build a home somewhere else or sell only the land and relocate the structure if the structure survived the flood. ${ }^{421}$ The city also ensured that there was space for the new or relocated structures: the city bought property outside of the floodplain and platted it specifically for homeowners relocating from the floodplains; other homeowners were moved either to rural sites or infill sites within the city. ${ }^{422}$ The city purchased property on higher grounds, within the Cherokee city limits, known as Colony Addition and established it specifically to provide an improved site for 22 of the 31 relocated homes. The houses were upgraded with better basements and foundations. As a result, most homeowners remained in the city, and the flood-prone, rundown properties are gone. Further, the city also implemented a down payment assistance program for low-income residents that provided as much as $\$ 22,000$ for a down payment on a new home. $^{423}$

As a result of the program, most homeowners remained in the city, ${ }^{424}$ which may have added to the desire of homeowners to participate in the program, thereby contributing to its successfulness. Only a few homeowners in the targeted buyout area remained behind. ${ }^{425}$ When floods again hit the city in 2010, the damage in the buyout area was "much less severe," even though the flooding was arguably worse than it was in $1993 .{ }^{426}$ The city of Cherokee's total acquisition cost was about $\$ 7.2$ million. ${ }^{427}$ FEMA, through its Hazard Mitigation Grant Program (HMGP), funded $75 \%$ of the project. The remaining $25 \%$ of the project cost was shared between the city of Cherokee and the state of lowa. The lowa Homeland Security and Emergency Management Division administered the funds. ${ }^{428}$

Cherokee's experience demonstrates the importance of relocation in a buyout program and the need for government to ensure enough open, platted land within the city for residents to move to. Of course, identifying open land spaces will not always be possible, particularly in denser, more populated cities, but local officials should take some steps to identify alternate development sites, whether physical land space or high occupancy apartment buildings, in order to supplement the housing market. 


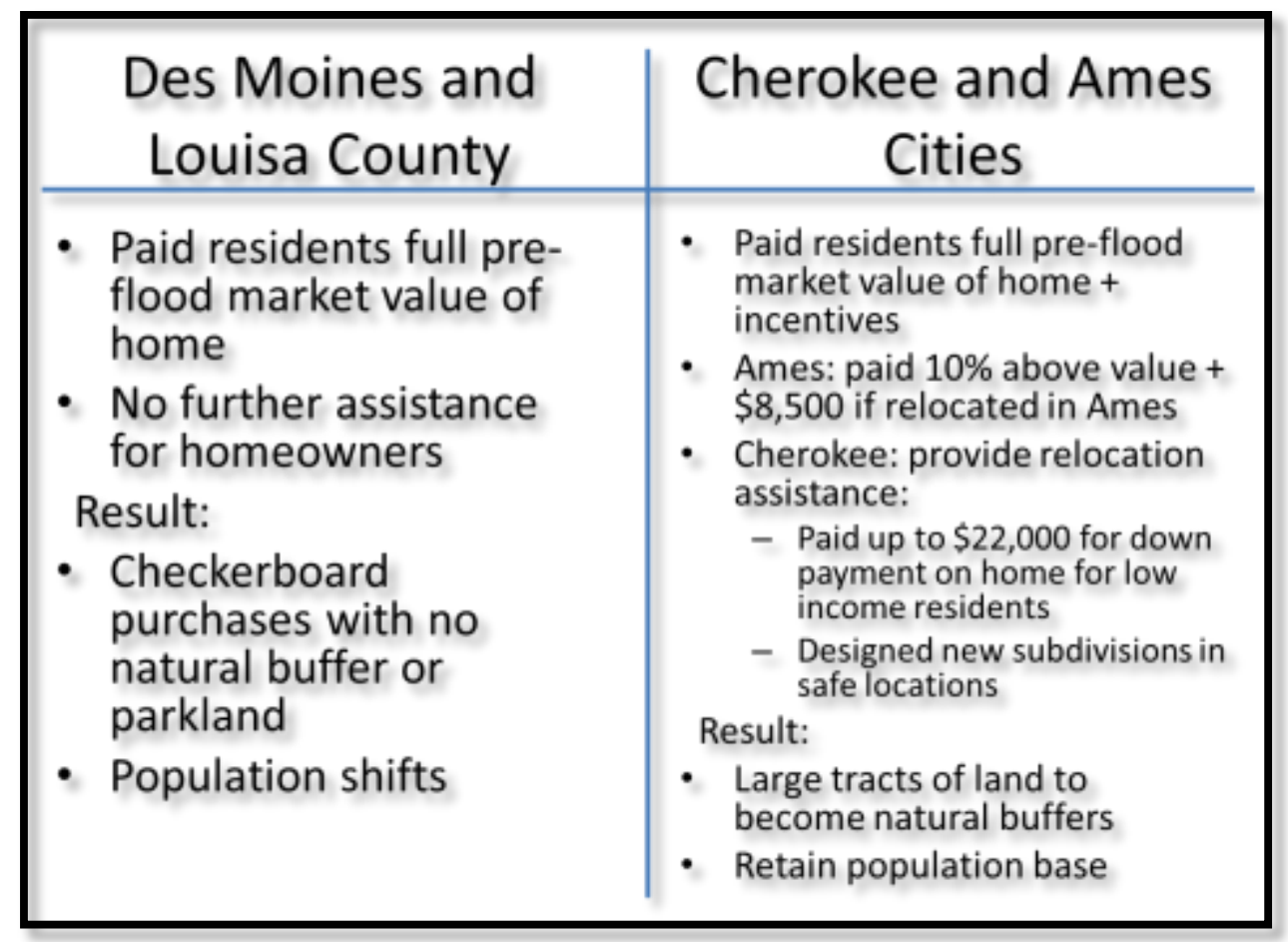

Compiled Comparison of lowa Buyout Programs. 


\section{Solving THE CHECKERBoARD - ChARlotTe, NC429}

From 2000 to 2012, Storm Water Services in the Charlotte-Mecklenburg metropolitan area in North Carolina administered a series of buyout programs resulting in the acquisition of 200 buildings at greatest risk of repeat flood damage from nearby creeks using FEMA HGMP funding and an additional 60 buildings using local funds. In some cases, one house would qualify for a buyout because of interior flood damage, but the house next door did not qualify because its living space is above flood heights. This resulted in a "checkerboard" pattern with some isolated "orphan" properties in the regulated floodplains.

In 2012, the Board of County Commissioners in Charlotte, North Carolina, approved an Orphan Property Floodplain Acquisition Plan to acquire these orphan properties and complete the floodplain acquisition. This was a complementary and simultaneous effort to the Flood Risk Assessment and Risk Reduction Plan that continued to evaluate new floodplain areas.

Storm Water Services identified 17 homes in 5 neighborhoods whose property touched on the floodway and whose removal would allow the street to be abandoned and the roadway removed. The 17 homes were located on seven dead end streets, three of which had only one orphan property. On those streets with multiple homes, offers were made to homes closest to the dead end first, so that some portion of the roadway could be abandoned. Owners are offered fair market value and sale of property is voluntary. Property owners are being contacted in 2013.

Estimated costs: \$2.056 million (includes appraisal, acquisition and demolition)

\section{EMINENT DOMAIN}

The buyout programs discussed above are all voluntary programs, in which the homeowner has agreed to sell coastal property. However, the government can acquire shoreline properties using eminent domain, even without the consent of the owner, if the government pays the owner compensation and is pursuing a legitimate public purpose. ${ }^{40}$

What constitutes a legitimate public purpose is usually left to the discretion of the implementing government agency so long as the purpose has clear public benefits. Public safety, served by removing homes and other structures from vulnerable areas, and preserving public funds by not spending on infrastructure in vulnerable coasts, are clear public purposes 
that the government can use condemnation to pursue. ${ }^{431}$ This will be especially true if the government can show a history of repetitive loss or that the property as an elevated risk of exposure to coastal hazards. ${ }^{432}$ It is not even necessary for the public benefit to accrue immediately. According to the Supreme Court, "In determining whether the taking of property is necessary for public use not only the present demands of the public, but those which may be fairly anticipated in the future may be considered." 433

Eminent domain is a legally well-established too, but buying property outright, especially when owners oppose the purchase, is likely to be an extremely expensive proposition, and it is also politically controversial. ${ }^{434}$

\section{Condemnation with a Conditional Lease}

Rather than purchase property today or delay a political decision until the threat is imminent, policy makers could take a middle road. Specifically, government could purchase property and lease the property back until it becomes uninhabitable due to changes in the shoreline or increased threat from coastal storms. ${ }^{435}$ The Supreme Court has specifically recognized that eminent domain can apply to property rights that are less than total ownership in fee: "The taking by condemnation of an interest less than the fee is familiar in the law of eminent domain." ${ }^{436}$ Importantly, payments from conditional leases would substantially offset the cost of acquiring the property - reducing the cost by more than $99 \% .{ }^{437}$

Conditional leases have the potential to address the future harms of slow-onset sea level rise and beach erosion. However, they do nothing to address the present dangers of coastal storms and thus, if implemented, would need to be combined with other protective measures in order to ensure the safety of coastal dwellers.

\section{LESSONS LEARNED AND RECOMMENDATIONS}

- Relocation is key. Municipalities and states considering a buyout program must consider where they want development to occur, identify those areas, and build in elements of their buyout program that assist homeowners in relocating to those desired areas. Some ways to do this are providing incentives for relocation within the district, providing assistance for down payments for low-income residents, and identifying areas of safe growth in a development plan. Areas for targeted development should be identified well in advance of a disaster. And new housing should be priced to be equally or less expensive than the housing that was acquired.

- Incentivize homeowners to remain nearby. This will not only assist in maintaining the tax base but also retain a greater sense of community. Government agencies can do this by offering bonus payments for homeowners to relocate nearby or by developing new housing areas. 
- Move quickly. Buyout programs are most successful when initiated immediately after a natural disaster. Have the plan in place in advance so that it can be implemented quickly. Place a deadline on accepting offers in order to make homeowners make a decision. Dedicate staff to process applications quickly.

- Identify priority homes based on greatest vulnerability. Repetitive loss areas are particularly cost-effective areas for buyout programs.

- Make homeowners aware of the benefits of acquisition. This is true for both conservation easements and buyout programs. Conduct a targeted information campaign to educate homeowners on the dangers and costs associated with remaining in a vulnerable area.

- Keep the program cost effective. Place a cap on the amount offered for homes or easements. Use a standard formula to determine property value in order to avoid long negotiation periods and hold-outs.

- Create floodplains. Attempt to buy large continuous areas of land in order to create floodplains that can act as barriers to future flooding. Return to areas after the fact and offer programs targeted at 'orphan houses.' Offer incentives for neighborhoods to move as a complete block. Target small locations: a program does not need to be large to be successful.

- Take the opportunity to invest in improvements. When buying properties, consider public spaces that would most improve the community. When rebuilding in safer locations, consider new building codes, solar power, and other design changes that would make those areas more desirable and resilient.

- Publicity and transparency are key. Working with NGOs can increase flexibility of programs, and working with the public builds trust and allows the community to have a voice in how the acquired land is used.

- Consider a combination of options such as acquisition through eminent domain coupled with the use of a conditional lease in order to lower costs. However, recognize that this path will provide protection only against the future harms of sea level rise and not against coastal storms that are affecting coastal properties even today.

- Be flexible and creative. Conservation easements can be designed to adapt to everyone's needs, making them more beneficial to landowners while still achieving the buffer needs. Working with NGOs and other agencies can give the project greater flexibility. 


\section{FURTHER READING}

Elizabeth Byers and Karin Marchetti Ponte, The Conservation Easement Handbook (The Land Trust Alliance, 2005).

The Risk is Real: Mitigation Works, Mitigation Best Practices: Public and Private Sector Best Practice Stories for Acquisition/Buyouts Activity/Project Types in All States and Territories Relating to FLoOding HAZARDS (FEMA, March 25, 2005).

David R. Goldschalk et al., Natural Hazard Mitigation: Recasting Disaster Policy and Planning 202, 207-212 (1999).

interagency floodplain Management Review Committee, Sharing the Challenge: Floodplain MANAgement INTO THE $21^{\text {ST }}$ Century (Gerald Galloway, Executive Director; U.S. Government Printing Office, 1994).

National Wildife federation, Higher Ground: A Report on Voluntary Property Buyouts in the NATION'S FLOODPLAINS 19 (July 1998).

\section{REFERENCES}

${ }^{336}$ Elizabeth Byers and Karin Marchetti Ponte, The Conservation Easement Handbook (The Land Trust Alliance, 2005) 8; see also George T. Davis, Protecting Scenic Views: Seventy Years of Managing and Enforcing Scenic Easements along the Blue Ridge Parkway (May 5, 2009) 2 (Master's Thesis, Virginia State University), available at http://scholar.lib.vt.edu/theses/available/etd-05202009-113831/unrestricted/GTomDavisThesisJune2009rev.pdf.

337 National Conservation Easement Database, http://www.conservationeasement.us/reports/easements (accessed July 2, 2013).

${ }^{338}$ For the distinction between voluntary and purchased development rights, see John B. Wright, Designing and Applying Conservation Easements, 60 Journal of the AMERICAN PLANNING AsSOCIATION 380 (1994), available at http://dx.doi.org/10.1080/01944369408975596.

339 NOAA, Coastal and Estuarine Land Conservation Program, http://coastalmanagement.noaa.gov/land; Department of Ecology State of Washington, Coastal \& Estuarine Land Conservation Program, http://www.ecy.wa.gov/programs/sea/wetlands/stewardship/celcp.html (last visited Oct. 14, 2013).

${ }^{340}$ Donations of open-space easements that meet federal tax code requirements may entitle the donor to federal income tax deductions. Standards are established by Internal Revenue Code $\$ 170(\mathrm{~h})$ and accompanying Treasury Regulations $\S \S 1.170 \mathrm{~A}-14$, et seq. For tax years 2012 and 2013, the deduction is limited to $50 \%$ of adjusted gross income, which if not used up in 2012 or 2013, may be carried forward at 50\% of adjusted gross income for an additional fifteen years or until the donation is fully expended, whichever comes first. In addition, a farmer or rancher who has received in 2012 or 2013 more than 50\% of adjusted gross income from farming or ranching is eligible for a tax deduction of $100 \%$ of adjusted gross income. 
${ }^{341}$ §39-22-522 Colorado Revised Statutes. See also Colorado Department of Revenue Taxpayer Service Division, FYI Income 39: Gross Conservation Easement Credit (2012), http://www.colorado.gov/cms/forms/dortax/Income39.pdf.

${ }^{342}$ Virginia's Land Conservation Incentives Act, $§ 58.1$ - 512 Virginia Code (2002). See also, Virginia Department of Conservation and Recreation, Land Preservation Credit, http://www.dcr.virginia.gov/land conservation/lpc.shtml (last accessed Aug. 14, 2013).

${ }^{343}$ Philip M. Hocker and Joseph H. Maroon, Virginia's State Tax Credit for Land Conservation: Protecting Virginia's Landscapes with Tax Credit Incentives, 134, 135 in A SuSTAINABLE CHESAPEAKE: BetTER Models fOR CONSERVATION (The Conservation Fund, David G. Burke and Joel E. Dunn, eds., 2010), available at http://www.conservationfund.org/asustainable-chesapeake-better-models-for-conservation.

344 Id., at 135.

${ }^{345}$ Virginia Department of Conservation and Recreation, supra note 342.

${ }^{346}$ Internal Revenue Code, 26 U.S.C. § 2031(c).

${ }^{347}$ See Wright, supra note 338.

${ }^{348}$ U.S. Fish and Wildlife Service, Habitat Management Techniques: Conservation Easements...Private Rights and Public Benefits, http://www.fws.gov/mountain-prairie/pfw/r6pfw8b.htm (last accessed Aug. 14, 2013).

${ }^{349}$ See e.g. National Oceanic and Atmospheric Administration, Achieving Hazard-Resilient Coastal \& Waterfront Smart Growth, p.10 (2011), available at http://coastalsmartgrowth.noaa.gov/pdf/hazard resilience.pdf.

${ }^{350}$ See James A. Coon, New York Department of State, Transfer of DeVelopment Rights 1 (2010), available at http://www.dos.ny.gov/lg/publications/Transfer of Development Rights.pdf.

${ }^{351}$ See Rick Pruetz and Noah Standridge, What Makes Transfer of Development Rights Work?, 75 JOURNAL OF THE American Planning Association, 75, 78 (2009).

352 Johnston, Robert A. and Madison, Mary E., From Landmarks to Landscapes: A review of Current Practices in the Transfer of Development Rights, 63 JOURNAL OF THE AMERICAN PLANNING ASSOCIATION 365 (Summer 1997).

${ }^{353}$ Arthur C. Nelson, Rick Pruetz, and Doug Woodruff, The TDR handbook: Designing and Implementing TRansfer of DeVElopment Rights Programs (2012) at 259, tbl. C.3.

${ }^{354}$ Paul Thorsnes, Gerald P. Simmons, Letting the Market Preserve the Land: The Case for a Market-Driven Transfer of Development Rights Program, 17 CONTEMPORARY ECONOMIC POLICY 256 (1999).

355 Id.

${ }^{356} / d$.

${ }^{357}$ See Stephanie Ramia, Smart Growth: The Toolbox for Addressing Sprawling Development in Coastal South Carolina, 19 SOUtheAstern EnVtL. L.J. 173, 209 (Fall 2010) citing David J. Harmon, Comment: Problems and Opportunities for Progressive Comprehensive Land Use Planning in Richland County, South Carolina After McClanahan v. Richland County Council, 45 SOUtH CAROLINA LAW ReVIEW 837, 838 (Spring 2003).

358 See Pruetz and Standridge, supra note 351, at 78.

359 Id.

${ }^{360}$ Id.

${ }^{361}$ Id.

362 Id. at.82.

${ }^{363}$ Id. 
${ }^{364}$ Id., at.83.

365 See David R. Goldschalk et Al., Natural hazard Mitigation: Recasting Disaster Policy and Planning 202, $207-212$ (1999); Christine A. Fazio \& Ethan I. Strell, Government Property Acquisition in Floodplains After Hurricane Sandy, N.Y. LAW JOURNAL, Feb. 28, 2013.

${ }^{366}$ National Wildlife Federation, Higher Ground: A Report on Voluntary Property Buyouts in the Nation's Floodplains 19 (July 1998), available at

http://www.nwf.org/ /media/PDFs/Water/199807 HigherGround Report.pdf?dmc=1\&ts=20130304T1054083281

${ }^{367}$ Id., at 39. FEMA estimates that "every \$1 paid toward mitigation saves an average of \$4 in future disasterrelated costs." Mitigation Saves Time, Money, and Possibly Lives, FEMA (Nov. 8, 2006), http://www.fema.gov/news-release/2006/11/08/mitigation-saves-time-money-and-possibly-lives, citing Multihazard Mitigation Council, Natural Hazard Mitigation Saves: An Independent Study to Assess the Future Savings FROM MitigATION ACTIVITIES (2005), available at http://www.nibs.org/?page=mmc projects\#nhms.

368 John Crompton, The Impact of Parks and Open Spaces on Property Values, 63 CALIFORNIA PARKS AND RECREATION 32 (2007); see also John Crompton, The Proximate Principle: The IMPACt of Parks, Open SPACES ANd WATER FeAtURES ON Residential Property Values ANd the Property TAX BASe (National Research and Parks Association, 2004) (reviewing 50 research studies conducted in 21 states).

${ }^{369}$ Mark Correll, Jane Lillydahl, and Larry Singell, The effect of green belts on residential property values: Some findings on the political economy of open space, 54 LAND ECONOMICs 207 (1978); see also Sarah Nicholls and John Crompton, The Impact of Greenways on Property Values: Evidence from Austin, Texas, 37 JOURNAL OF LEISURE RESEARCH 321, 322 (2005); Margot Lutzenhiser and Netusil Noelwahr, The effect of open spaces on a home's sale price, 19 CONTEMPORARY ECONOMIC POLICY 291 (2001).

${ }^{370}$ See Hazard Mitigation Assistance-Property Acquisition (Buyouts), FEMA, last updated Dec. 27, 2012, http://www.fema.gov/application-development-process/hazard-mitigation-assistance-property-acquisitionbuyouts (last visited Aug 14., 2013).

${ }^{371}$ FEMA actions must satisfy the National Environmental Policy Act (NEPA). However, the Sandy Recovery Improvement Act of 2013 created a streamlined environmental review process. See Fazio, supra note 365 . The Act requires that "adequate resources are devoted to ensure that applicable reviews under" NEPA are completed quickly and that the shortest applicable NEPA process be used for review. Sandy Recovery Improvement Act of 2013, Pub. L. No. 113-2, § 1104, 127 Stat. 4 (2013).

${ }^{372} 42$ U.S.C. $\S 5170 c(a)$. For FEMA's cost-benefit analysis tools, see Benefit-Cost Analysis, FEMA, last updated Feb. 1, 2013, http://www.fema.gov/benefit-cost-analysis (last visited Aug. 14, 2013).

${ }^{373} 42$ U.S.C. $\S 5170 c(b)(2)(B)(i),(b)(2)(i i)(I)-(I I I),(b)(2)(i i i)$. See also Allocations, Common Application, Waivers, and Alternative Requirements for Grantees Receiving Community Development Block Grant (CDBG) Disaster Recovery Funds in Response to Hurricane Sandy, 78 Fed. Reg. 14329, 14345 (Mar. 5, 2013) (hereinafter "HUD March 2013 Guidelines").

374 Required Pre-Award Documents for Mitigation Projects, FEMA, last updated Mar. 10, 2013, http://www.fema.gov/application-development-process/required-pre-award-documents-mitigation-projects (last visited Aug. 14, 2013).

${ }^{375} 42$ U.S.C. $\S 5170 \mathrm{c}(\mathrm{b})(2)(\mathrm{ii})(\mathrm{I})-(\mathrm{III})$; see also HUD March 2013 Guidelines, supra note 373 , at 14345 (stating that flood control structures may be built on acquired land).

${ }^{376}$ Hazard Mitigation Assistance-Property Acquisition (Buyouts), supra note 370.

${ }^{377} 42$ U.S.C. $\S 5170 c(c)(2)(A)-(C)$.

${ }^{378}$ See Thomas Kaplan, Cuomo is Seeking to Curb Building in Flooded Area, N.Y. TIMES, Feb. 4, 2013, at A1, available at http://www.nytimes.com/2013/02/04/nyregion/cuomo-seeking-home-buyouts-in-flood-zones.html. 
${ }^{379}$ Section draws information from: Soldiers Grove, Wisconsin, America's First Solar Village: The Floods, last updated Jan. 29, 2011, http://www.soldiersgrove.com/Floods.htm (last visited Aug. 14, 2013); WILLIAM S. BECKER, Rebuilding for the Future...SUStainAble Development for DiSASTer-AfFected Communities 12-15 (U.S. Department of Energy, 1994), available at http://www.climateactionproject.com/docs/Rebuilding for the Future.pdf; FEMA, Soldiers Grove Reflects on Moving, MITIGATION BEST PRACTICES (Fall 2007), available at http://www.soldiersgrove.com/FEMA\%20Newsletter\%202007.pdf; FEMA, Small Wisconsin Villages Leads the Nation: Rebuilds Above Floodwaters, https://www.llis.dhs.gov/printpdf/46221 (last visited Aug. 14, 2013); FEMA, Village Locals Reflect: Moving Was Best Flood Protection, https://www.llis.dhs.gov/printpdf/46220 (last visited Aug. 14, 2013).

380 See e.g., Interagency Floodplain Management ReView Committee, Sharing the Challenge: Floodplain Management INTO THE $21^{\text {ST }}$ CENTURY (Gerald Galloway, Executive Director; U.S. Government Printing Office, 1994) (hereinafter "Galloway Report") (placing damage at \$12 to \$16 billion). For a discussion of the disaster, see also Gerald E. Galloway Jr., Learning from the Mississippi Flood of 1993: Impacts, Management Issues, and Areas for Research, U.S.-Italy Research Workshop on the Hydrometeorology, Impacts, and Management of Extreme Floods, Perugia, Italy, November 1995, http://www.engr.colostate.edu/ jsalas/us-italy/papers/12galloway.pdf (noting more than 100,000 homes were damaged); Gloria Bucco, Flood of the Century: Remembering the Great Midwest Flood of 1993, Nebraska Department of Natural Resources, http://www.dnr.ne.gov/floodplain/PDF Files/FloodUpdateStory Rev3.pdf (last visited Aug. 14, 2013) (estimating damage at $\$ 20$ billion).

${ }^{381}$ See Galloway Report, supra note 380, at 11; Lee Larson, The Great USA Flood of 1993, National Weather Service, presented at IAHS Conference, Destructive Water: Water-Caused Natural Disasters - Their Abatement and Control, Anaheim, California, June 24-28, 1996, available at http://www.nwrfc.noaa.gov/floods/papers/oh 2/great.htm (last visited Aug. 14, 2013); Harry Hillaker, Iowa State Climatologist, Iowa Department of Agriculture, SpeCial SUMmARY,GREAT IOWA FLOODS, 1993 (Des Moines, lowa, September 7, 1993).

${ }^{382}$ See Larson, supra note 381.

383 See lowa Flood Recovery Coordination Team, The Floods of 1993: A Flood Disaster Report 1 (May 1994); Galloway Report, supra note 380, at 15; GOLDSCHALK ET AL., supra note 365, at 194-95.

${ }^{384}$ White House Office of the Press Secretary, President Clinton Declares 87 lowa Counties as Disaster Areas, July 14, 1993, available at http://clinton6.nara.gov/1993/07/1993-07-14-president-declares-87-more-iowa-counties-asdisaster-areas.html (noting "This addition brings to 99 the number of counties in lowa that are eligible for federal assistance").

${ }^{385}$ GoldSCHALK ET AL., supra note 365, at 193 ("The Clinton administration established buyouts . . . as the first priority for mitigation funds available for the Midwest floods"); NATIONAL WILDLIFE FEDERATION, supra note 366 , at 19 ("Not until the 1993 Midwest Flood . . . was the buyout and relocation option put to a real test.").

${ }^{386}$ Hazard Mitigation and Relocation Assistance Act of 1993, Pub. L. No. 103-181, § 2, 107 Stat. 2054.

${ }^{387}$ See IOWA Flood Recovery CoORdinAtion TeAm, supra note 383, Annex A: Department/Agency After Action Reports, lowa Department of Economic Development at 55; GoLDSCHALK ET AL., supra note 365, at 204.

${ }^{388}$ Id.

${ }^{389} / d$.

390 See GolDSCHALK ET AL., supra note 365, at 207.

391 Id., at 194, 205.

392 Id., at 211.

393 J. Peter Byrne \& Jessica Grannis, Coastal Retreat Measures, in THE LAW Of AdAPTATION TO CLIMATE CHANGE: UNITED StATES AND INTERNATIONAL ASPECTS 267, 284 (Katrina Fischer \& Michael B. Gerrard, eds., 2012). 
${ }^{394}$ See GolDSCHALK ET AL., supra note 365, at 208.

${ }^{395}$ Id., at 205-06.

${ }^{396}$ FEMA, Flood Survivor Decides Buyout Program Best Choice, 6 in THE RISK IS REAL: MITIGATION WORKS, MITIGATION Best Practices: Public and Private Sector Best Practice Stories for Acquisition/Buyouts Activity/Project Types in All States and Territories Relating to Flooding HaZards (FEMA, March 25, 2005).

${ }^{397}$ Id.

398 GolDSCHALK ET AL., supra note 365, at 211.

${ }^{399}$ Id.

${ }^{400}$ FEMA, Story County Acquisitions Properties Transformed for Training Uses, 145 in THE RISK IS REAL: MITIGATION Works, Mitigation Best Practices: Public and Private Sector Best Practice Stories for Acquisition/Buyouts Activity/Project Types in All States and Territories Relating to Flooding Hazards (FEMA, March 25, 2005).

${ }^{401}$ City of Ames Flood Mitigation Study, Presentation, available at

http://www.cityofames.org/modules/showdocument.aspx?documentid=10305 (last visited Aug. 14, 2013).

402 See Bruce G. Mountain, Case Study: How a Public/Private Partnership Transformed the Flood-Damaged LeVee District 8 In LoUisa County, IOWA, into the HORSEShOe Bend Division, Mark TWAin National Wildlife Refuge 5 (Oct. 25, 1995), available at http://www.leopold.iastate.edu/sites/default/files/events/case study.pdf. For the levee district dissolution requirements, see lowa Code $§ 468.250$ (2013).

403 Wetlands as Flood Control?, IOWA PUBLIC TELEVISION, Feb. 5, 2009, http://www.iptv.org/iowajournal/story.cfm/448/feature (last visited Aug. 14, 2013).

${ }^{404}$ Iowa Natural Heritage Foundation, Louisa County: Horseshoe Bend project models natural flood protection, July 2008, http://www.inhf.org/news.cfm?action=article\&id=6cc1996a-7fe6-40b1-a253-e21806eb0296 (last visited Aug. 14, 2013).

${ }^{405}$ See MounTAIN, supra note 402, at 5.

${ }^{406}$ See Wetlands as Flood Control?, supra note 403.

${ }^{407} / d$.

${ }^{408}$ See MounTAIN, supra note 402, at 7.

${ }^{409}$ Id.

${ }^{410} / d$.

${ }^{411} / d$. , at 9.

${ }^{412}$ Id.

${ }^{413} / d$.

${ }^{414}$ Id., at 11.

${ }^{415}$ FEMA, Buyout Resolves Flood Hazards for Many Homeowners, 4 in THE RISK IS REAL: MITIGATION WORKS, MITIGATION Best Practices: Public and Private Sector Best Practice Stories for Acquisition/Buyouts Activity/Project Types in All States ANd Territories Relating to Flooding Hazards (FEMA, March 25, 2005).

${ }^{416} / d$.

${ }^{417}$ Kate Hudson and Ursula Lemanski, Hard-earned lesson from the Midwest floods, National Park Service National Trails Training Partnership, October 1997, http://www.americantrails.org/resources/greenways/GrnwyFloodplains.html (last visited Aug. 14, 2013). 


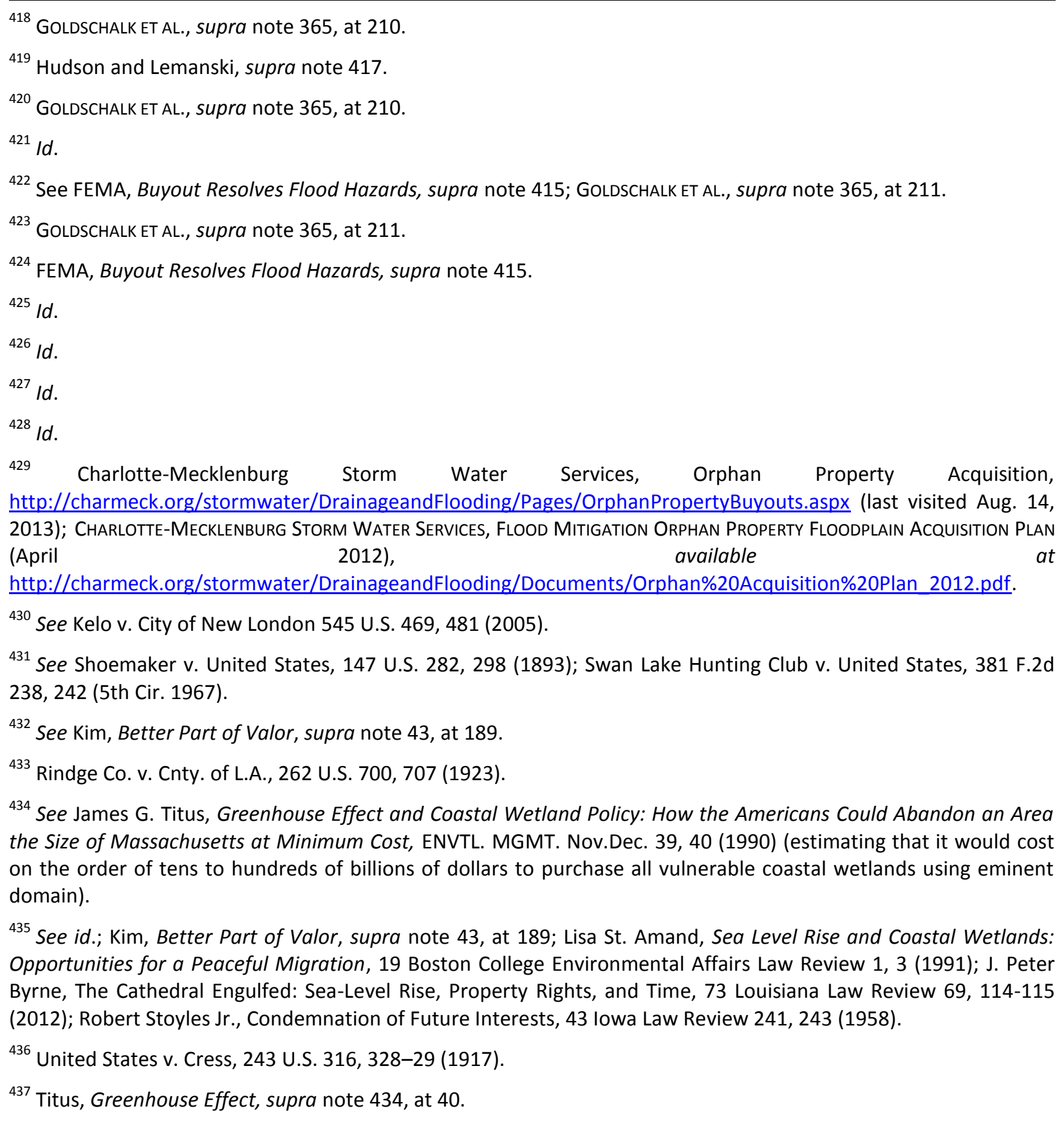




\section{APPENDIX}

\section{SAMPLE CONSERVATION EASEMENT AGREEMENT For a Save America's Treasures Grant (Historic Building) NATIONAL PARK SERVICE}

INTRODUCTION. This conservation easement agreement is made the day of , 20 between Organization, as GRANTOR of a conservation easement (hereafter referred to as the "Grantor"), and the SHPO/Covenant Holder, as GRANTEE of the conservation easement (hereafter referred to ask the "Grantee"). This conservation easement agreement is entered under State Law/Regulation for the purpose of preserving the Name of Property, a building that is important culturally, historically, and architecturally.

1. The Subject Property. This agreement creates a conservation easement in real estate legally described as ___Property Description

The Subject Property is the site of the Name of Property, located at _Street Address, City, County, \& State (hereafter referred to as the "Property").

2. Grant of conservation easement. In consideration of the sum of $\$$ received in grant-in-aid financial assistance from the National Park Service of the United States Department of the Interior, the Grantor hereby grants to the Grantee a conservation easement in the Subject Property for the purpose of assuring preservation of the Property.

3. Easement required for Federal grant. This conservation easement is granted as a condition of the eligibility of the Grantor for the financial assistance from the National Park Service of the United States Department of the Interior appropriated from the Historic Preservation Fund for the Save America's Treasures Grant Program.

\section{Conditions of easement:}

a. Duration. This conservation easement is granted for a period of fifty (50) years commencing on the date when it is filed with the County County Recorder.

b. Documentation of condition of the Property Name at time of grant of this easement. In order to make more certain the full extent of Grantor's obligations and the restrictions on the Subject Property, and in order to document the nature and condition of the Property, including significant interior elements in spatial context, a list of character-defining materials, features and spaces is incorporated as Exhibit " $A$ " at the end of this agreement. The Grantor has provided to the Grantee architectural drawings of the floor plans. To complement Exhibit " $A$ ", Grantee personnel have compiled a photographic record, including photographer's affidavit, black and white photographs and negatives, color digital prints, photograph logs, and a keyed location map. The Grantor agrees that the nature and condition of the Property on the date of execution of this easement is accurately 
documented by the architectural drawings and photographic record, which shall be maintained for the life of this easement in the Grantee's conservation easement file for the Property.

c. Restrictions on activities that would affect historically significant components of the Property. The Grantor agrees that no construction, alteration, or remodeling or any other activity shall be undertaken or permitted to be undertaken on the Subject Property which would affect historically significant interior spaces and features identified in Exhibit " $A$ ", exterior construction materials, architectural details, form, fenestration, height of the Property, or adversely affect its structural soundness without prior written permission of the Grantee affirming that such reconstruction, repair, repainting, refinishing, rehabilitation, preservation, or restoration will meet The Secretary of the Interior's Standards for the Treatment of Historic Properties (hereinafter referred to as the "Standards").

d. Restrictions on activities that would affect archeological resources. The Grantor agrees that no ground disturbing activity shall be undertaken or permitted to be undertaken on the Subject Property which would affect historically significant archeological resources identified in Exhibit " $A$ " without prior written permission of the Grantee affirming that such work will meet The Secretary of the Interior's "Standards for Archeology and

e. Maintenance of recovered materials. The Grantor agrees to ensure that any data and material recovered will be placed in a repository that will care for the data in the manner prescribed in the Standards for Archeology and Historic Preservation or will comply with the requirements of the Native American Graves Protection and Repatriation Act, and with 36 CFR 79 and 43 CFR 10.

f. Maintenance of recovered materials. The Grantor agrees to ensure that any data and material recovered will be placed in a repository that will care for the data in the manner prescribed in the Standards for Archeology and Historic Preservation or will comply with the requirements of the Native American Graves Protection and Repatriation Act, and with 36 CFR 79 and 43 CFR 10.

g. Duty to maintain the Property. The Grantor agrees at all times to maintain the Property in a good and sound state of repair and to maintain the subject Property, including the Other structures or features of the site, according to the Standards so as to prevent deterioration and preserve the architectural and historical integrity of the Property in ways that protect and enhance those qualities that make the Property eligible for listing in the National Register of Historic Places.

h. Public access. The Grantor agrees to provide public access to view the grant-assisted work or features no less than 12 days a year on an equitably spaced basis. The dates and times when the property will be open to the public must be annually published and provided to 
the Grantee. At the option of the Grantor, the relevant portions of the Property may also be open at other times by appointment, in addition to the scheduled 12 days a year. Nothing in this agreement will prohibit a reasonably nondiscriminatory admission fee, comparable to fees charged at similar facilities in the area. Right to inspect. The Grantor agrees that the Grantee, its employees, agents and designees shall have the right to inspect the Property at all reasonable times, with twenty-four hours written notice, in order to ascertain whether the conditions of this easement agreement are being observed.

i. Anti-discrimination. The Grantor agrees to comply with Title VI of the Civil Rights Act of 1964 (42 U.S.C. 2000 (d), the Americans with Disabilities Act (42 U.S.C. 12204), and with Section 504 of the Rehabilitation Act of 1973 (29 U.S.C. 794). These laws prohibit discrimination on the basis of race, religion, national origin, or disability. In implementing public access, reasonable accommodation to qualified disabled persons shall be made in consultation with the Grantee (or State Historic Preservation Office if another organization is holding the easement).

j. Easement shall run with the land; conditions on conveyance. This conservation easement shall run with the land and be binding on the Grantor, its successors and assigns. The Grantor agrees to insert an appropriate reference to this easement agreement in any deed or other legal instrument by which it divests itself of either the fee simple title or other lesser estate in the Property, the Subject Property, or any part thereof.

k. Casualty Damage or Destruction. In the event that the Property or any part of it shall be damaged or destroyed by fire, flood, windstorm, earth movement, or other casualty, the Grantor shall notify the Grantee in writing within 14 days of the damage or destruction, such notification including what, if any, emergency work has already been completed. No repairs or reconstruction of any type, other than temporary emergency work to prevent further damage to the Property and to protect public safety, shall be undertaken by the Grantor without the Grantee's prior written approval indicating that the proposed work will meet the Standards. The Grantee shall give its written approval, if any, of any proposed work within 60 days of receiving the request from the Grantor. If after reviewing the condition of the property, the Grantee determines that the features, materials, appearance, workmanship, and environment which made the property eligible for listing in the National Register of Historic Places has been lost or so damaged that its continued National Register listing is in question, the Grantee will notify the Keeper of the National Register (or the SHPO if the Grantee is not the State) in writing of the loss. The Keeper of the National Register will evaluate the findings and notify the Grantee in writing of any decision to remove the property from the National Register. If the property is removed, the Grantee will then notify the Grantor that the agreement is null and void. If the damage or destruction that warrants the properties removal from the National Register is deliberately caused by the gross negligence of the Grantor or future owner, then the Grantee will initiate requisite legal action to recover, at a minimum, the Federal grant funds applied to the property which will then be returned to the U.S. Treasury. 
I. Enforcement. The Grantee shall have the right to prevent and correct violations of the terms of this easement. If the Grantee, upon inspection of the property, finds what appears to be a violation, it may exercise its discretion to seek injunctive relief in a court having jurisdiction. Except when an ongoing or imminent violation will irreversibly diminish or impair the cultural, historical and architectural importance of the Property, the Grantee shall give the Grantor written notice of the violation and allow thirty (30) days to correct the violation before taking any formal action, including, but not limited to, legal action. If a court, having jurisdiction, determines that a violation exists or has occurred, the Grantee may obtain an injunction to stop the violation, temporarily or permanently. A court may also issue a mandatory injunction requiring the Grantor to restore the Property to a condition that would be consistent with preservation purposes of the grant from the National Park Service. In any case where a court finds that a violation has occurred, the court may require the Property to reimburse the Grantee and the State Attorney General for all the State's expenses incurred in stopping, preventing and correcting the violation, including but not limited to reasonable attorney's fees. The failure of the Grantee to discover a violation or to take immediate action to correct a violation shall not bar it from doing so at a later time.

m. Amendments. The parties may by mutual written agreement jointly amend this easement, provided the amendment shall be consistent with preservation purpose of this easement and shall not reduce its term of duration. Any such amendment shall not be effective unless it is executed in the same manner as this easement, refers expressly to this easement, and is filed with the _county__ County Recorder.

n. Effective date; severability. This conservation easement shall become effective when the Grantor files it in the Office of the Recorder of County County, State, with a copy of the recorded instrument provided to the Grantee for its conservation easement file. If any part of this conservation easement agreement is held to be illegal by a court, the validity of the remaining parts shall not be affected, and the rights and obligations of the parties shall be construed and enforced as if the conservation agreement does not contain the particular part held to be invalid.

\section{GRANTOR:}

By:

Name and Title 
STATE OF COUNTY, ss: On this day of , 2006, before me the undersigned, a Notary Public for said State, personally appeared Name of Person, to me personally known, who stated that he is Title and Organization, that no seal has been procured by said corporation, and that the foregoing instrument was signed on behalf of said corporation by authority of its Board of Directors, and that as such officer, he acknowledged that he executed the foregoing instrument as his voluntary act and the voluntary act of the corporation.

NOTARY PUBLIC

GRANTEE:

By:

Name and Title

STATE OF COUNTY, ss: On the day of 2006, before me, a Notary

Public for said State, personally appeared Name of Person, who stated that he is the duly appointed and actively serving Title and Organization, and that he executed the foregoing conservation easement agreement as his voluntary act and as the voluntary act of the State Department of Cultural Affairs.

NOTARY PUBLIC 
Managed Coastal Retreat: A Legal Handbook on Shifting Development Away from Vulnerable Areas (C) 2013 Columbia Center for Climate Change Law, Columbia Law School 